\title{
Landowners and biodiversity: Analysis of the potential of conservation on private land in the East of Bolivia
}

\author{
Dissertation \\ zur Erlangung des Doktorgrades \\ der Mathematisch-Naturwissenschaftlichen Fakultäten \\ der Georg-August-Universität zu Göttingen
}

vorgelegt von

Jorge Luis Choquehuanca Zeballos

aus La Paz, Bolivien

Göttingen 2005 
D7

Referent: $\quad$ Prof. Dr. Gerhard Gerold

Korreferent: Prof. Dr. Pierre L. Ibisch

Tag der mündlichen Prüfung: 


\section{Contents}

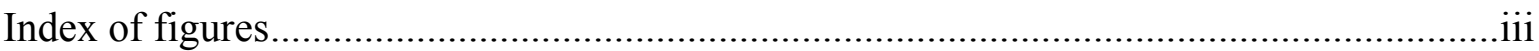

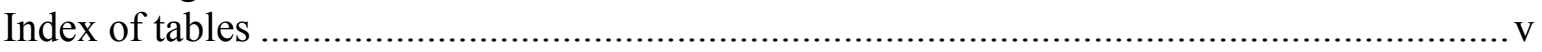

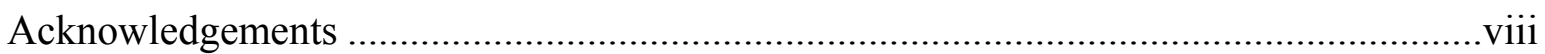

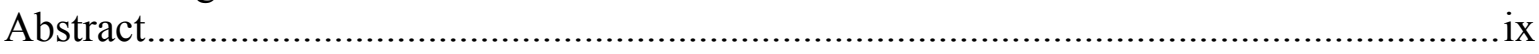

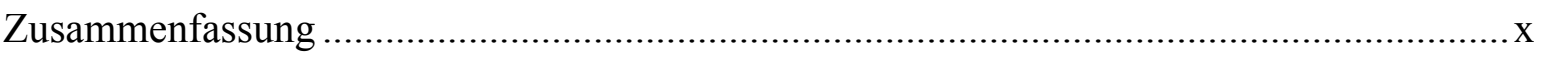

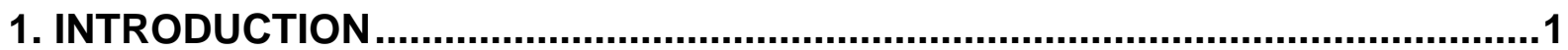

1.1. Argumentation and antecedents ................................................................................1

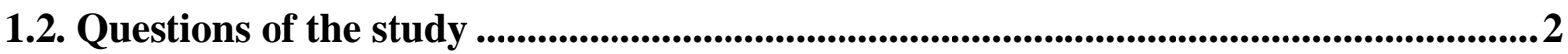

2. LITERATURE REVIEW................................................................................. 4

2.1. The paradigm of private land conservation and its contribution to the conservation biology goals ....................................................................................................................................4

2.2. Methods and incentives to protect private land in the context of Latin America ........7

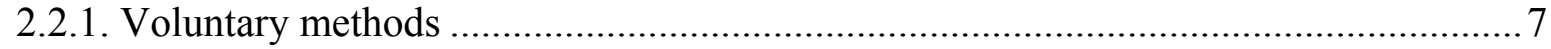

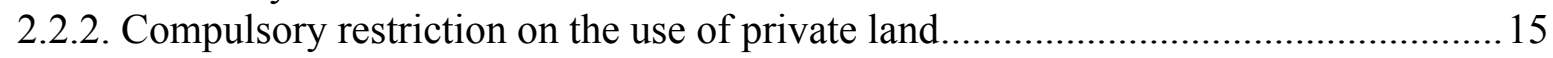

2.2.3. Incentives: the key to private land conservation .................................................. 18

2.3. Private conservation in Bolivia: Methods and results of the first efforts..................20

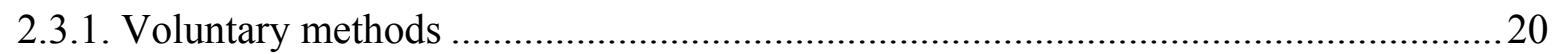

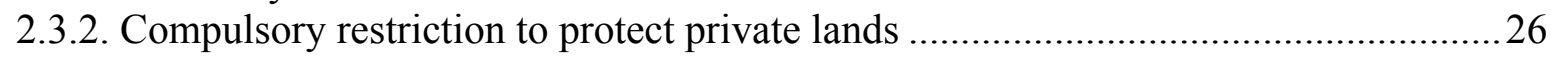

3. GENERAL ASPECTS OF THE STUDY AREA: THE TRANSITIONAL REGION CHIQUITANO-AMAZON TR-CHA .................................................................28

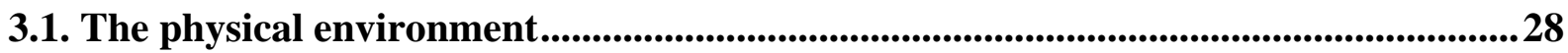

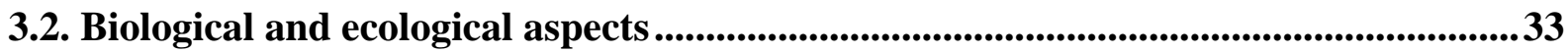

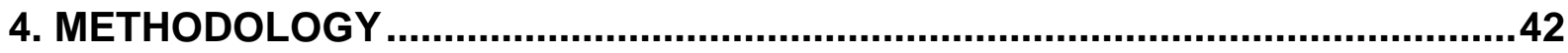

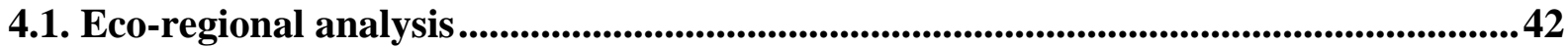

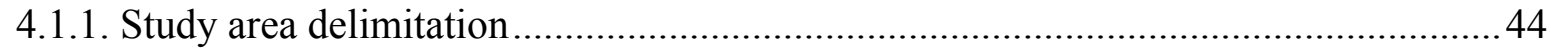

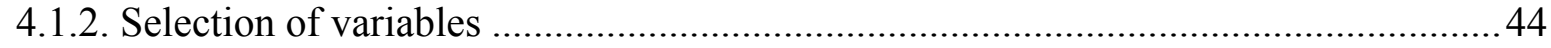

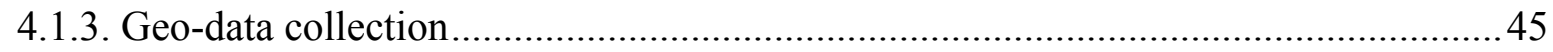

4.1.4. Representation and classification of variables in geographic maps ........................ 46

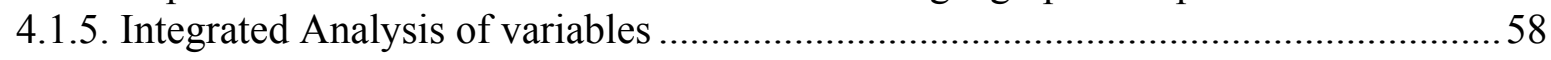

4.2. Case study

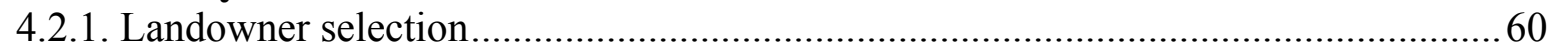

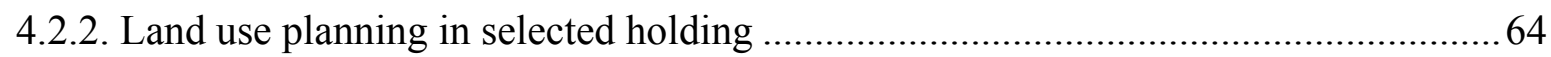

4.2.3. Design of a management plan for private reserves and monitoring .........................65 
5.1. Ecoregional analysis and conservation priorities in the study area............................67

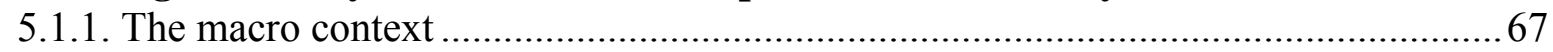

5.1.2. The bio-ecological importance of the conservation of the study area.......................6 68

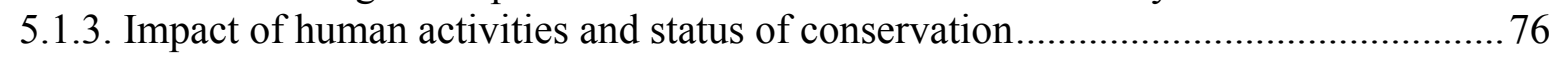

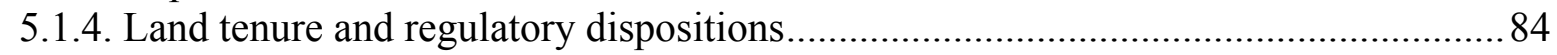

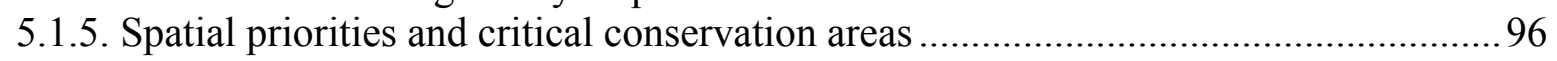

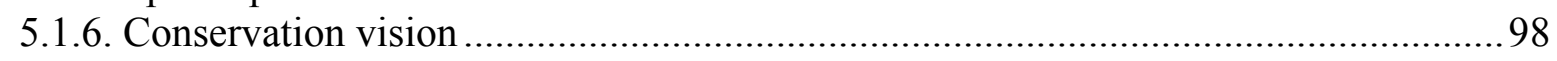

5.2. Private landowners and biodiversity: the owners' predisposition to conservation. 102

5.2.1. Traditional land use systems and their influence on biodiversity ........................... 103

5.2.2. Land use pattern under conservationist perspective ........................................... 113

5.2.3. Discussion about the landowners' predisposition to set aside areas for biodiversity

5.2.4. Evaluation of the implementation of land-use and management plans of private

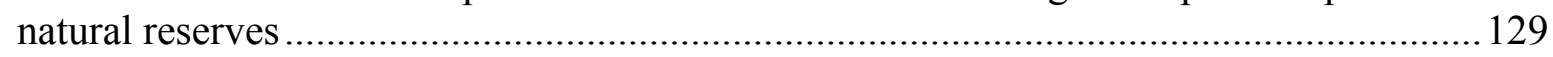

5.2.4. Identified factors that impede the establishment of private natural reserves ........... 131

5.3. Recommended measures and strategies to promote private land conservation .......135

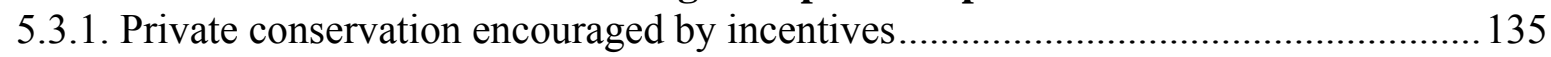

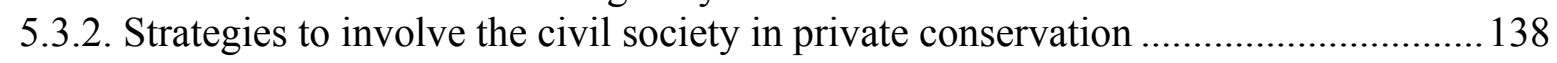

5.4. Implications from the study for conservation policies ..............................................141

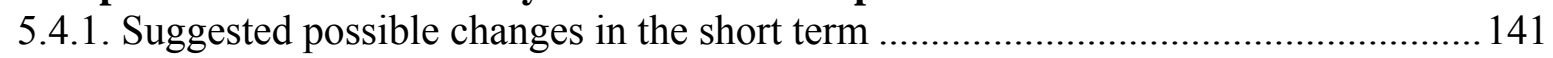

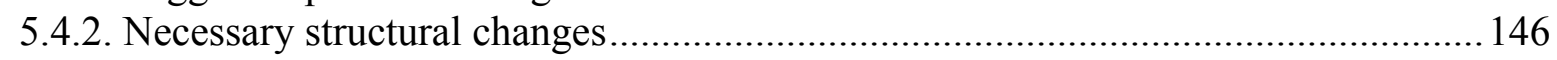

5.5. Scenarios and perspectives for private land conservation.......................................148

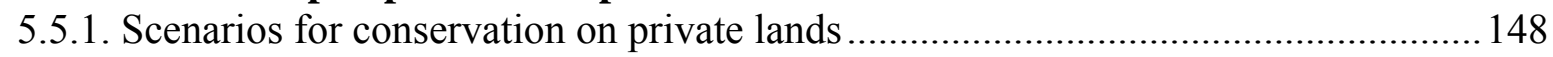

5.5.2. Private conservation opportunities among the social conflicts of Bolivia ................ 151

6. CONCLUSIONS AND RECOMMENDATIONS ...............................................153

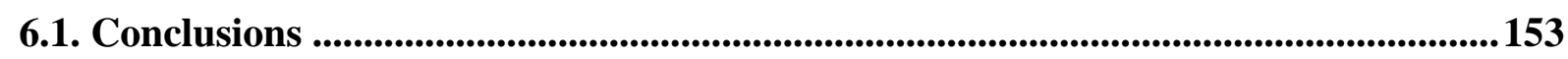

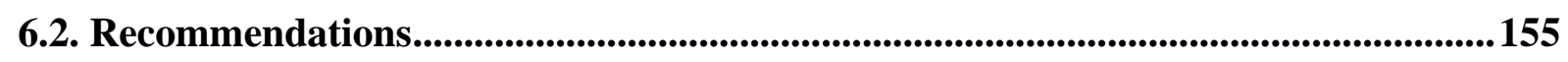

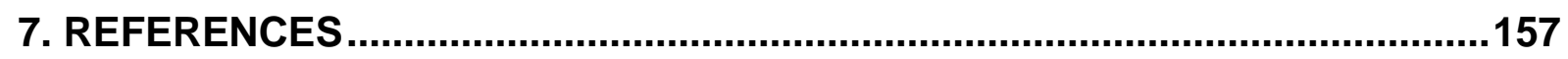

Annex 


\section{Index of figures}

Figure 1: Location of Natural Heritage Private Reserves and national protected areas...........22

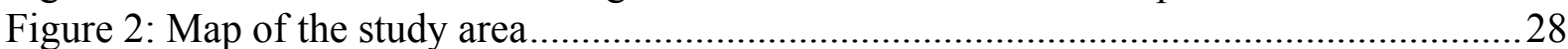

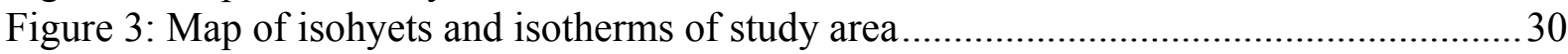

Figure 4: Climate diagram for San Ignacio de Velasco......................................................... 30

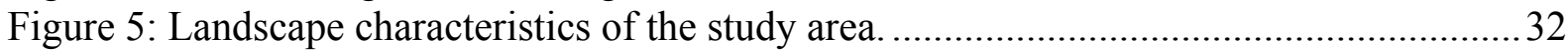

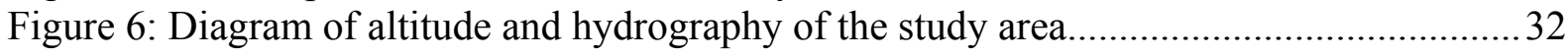

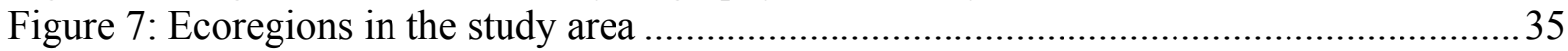

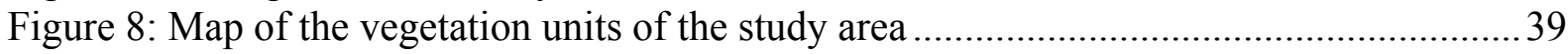

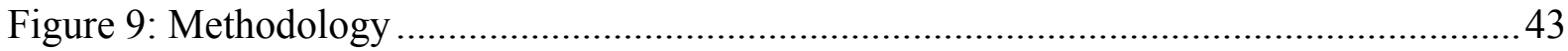

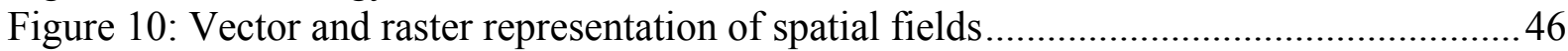

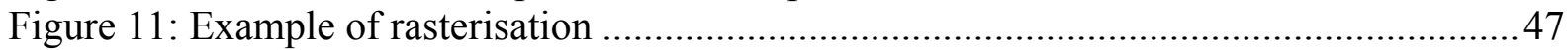

Figure 12: Location of the study area and distribution of deciduous and evergreen forest in

South America....

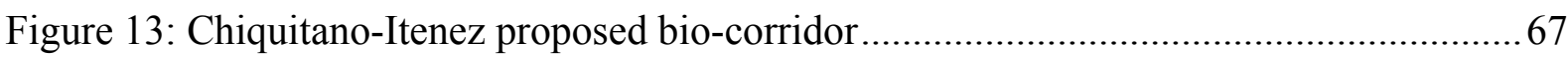

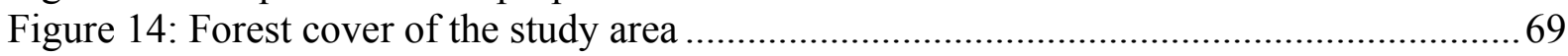

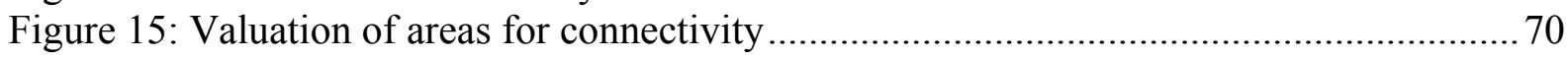

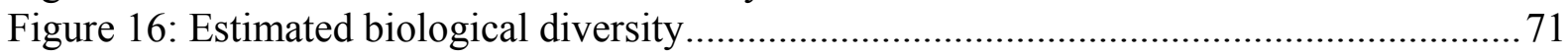

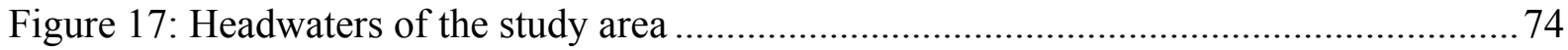

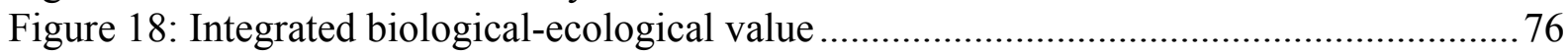

Figure 19: Grade of impact on biodiversity due to population centres ................................. 77

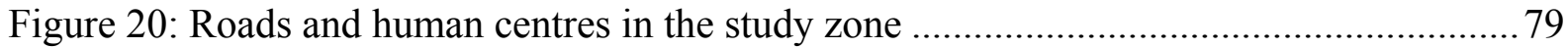

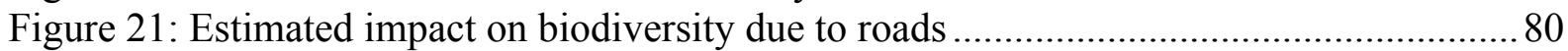

Figure 22: Estimated impact due to deforestation and land use ........................................... 81

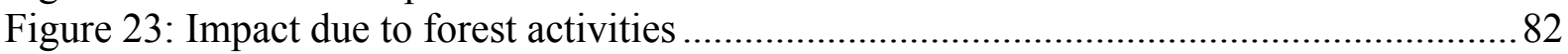

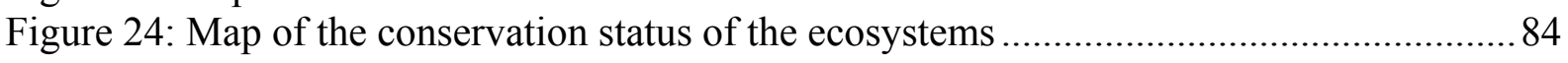

Figure 25: Location of municipal forest areas and the municipal protected area.................... 85

Figure 26: Comparison of the forest areas with the municipal protected area regarding the bio-

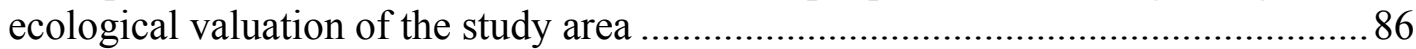

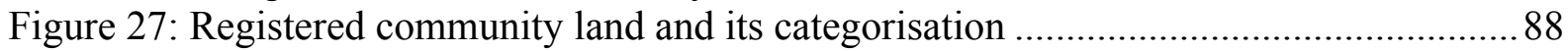

Figure 28: The location of community land in the study zone and its conservation status......89

Figure 29: Location and categorisation of registered private holdings ................................. 90

Figure 30: Private holding locations and the conservation status of the study area ................91

Figure 31: Geographical cover of regulatory dispositions of land use ...................................93

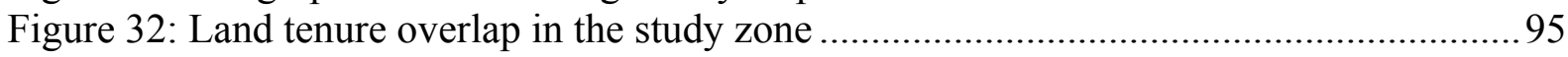

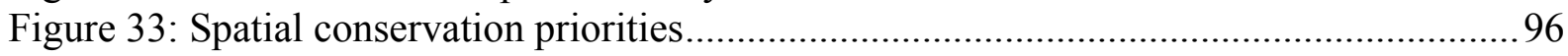

Figure 34: Relation between spatial conservation priorities and land tenure underlining

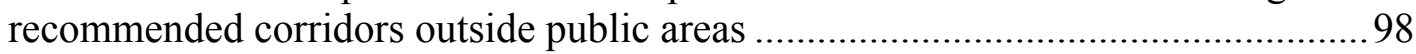

Figure 35: Proposed preliminary conservation vision................................................... 101

Figure 36: Location of selected case study and vision of conservation .............................. 102

Figure 37: Distribution in percent of traditional land use in holdings located in the Chiquitano Forest ecoregion

Figure 38: Comparison between the number of registered bird and mammal species in selected holdings of the Chiquitano Forest and the expected number of species for this ecoregion.....

Figure 39: Distribution in per cent of land use under traditional system in holdings with characteristics of the ecoregions Chiquitano Forest and Cerrado 
Figure 40: Comparison between the number of registered species in holdings with characteristics of the Chiquitano Forest and the Cerrado and the expected number of species for these areas.

Figure 41: Distribution of land use under traditional system in holdings of the ecoregion of the Flooded Amazon Savanna.....

Figure 42: Comparison between the number of registered species in the holdings of the Flooded Amazon Savanna ecoregion and the registered number of the species of the Noel Kempff National Park.

Figure 43: Comparison of the given land-use status in 2003 and the proposed land-use arrangement of the holdings located in the ecoregion of the Chiquitano Forest. Holdings a1-ch, a2-ch, and a3-ch

Figure 44: Comparison of the given land-use status in 2003 and the proposed land-use arrangement of holding a4-ch, located in the Chiquitano Forest ecoregion.

Figure 45: Comparison of the given land-use status in 2003 and the proposed land-use arrangement of holdings located in the ecoregion of the Chiquitano Forest. Holdings b1-ch, b2-ch, and b3-ch.

Figure 46: Per cent distribution of the proposed land-use categories in each holding of the Chiquitano Forest ecoregion.

Figure 47: Comparison of the given land-use status in 2003 and the proposed land-use arrangement of holdings with characteristics of Chiquitano Forest and Cerrado ecoregion. Holdings: a5-ch-ce, a6-ch-ce, and a7-ch-ce.

Figure 48: Comparison of the given land-use status in 2003 and the proposed land-use arrangement of holdings with characteristics of Chiquitano Forest and Cerrado ecoregion. Holdings: b4-ch-ce, b5-ch-ce, and b6-ch-ce

Figure 49: Per cent distribution of proposed land-use categories in holdings with characteristics of the ecoregions Chiquitano Forest and Cerrado

Figure 50: Comparison of the given land-use status in 2003 and the proposed land-use arrangement of holdings of Flooded Amazon Savanna ecoregion.

Figure 51: Per cent distribution of proposed land-use categories in holdings of the ecoregion

of the Flooded Amazon Savanna.

Figure 52: Chronological increase of Natural Heritage Private Reserves in Bolivia. 


\section{Index of tables}

Table 1: Number and surface (ha) of private reserves in some Latin America countries ........ 10

Table 2: Summary of legal framework and incentives of private reserves in some Latin

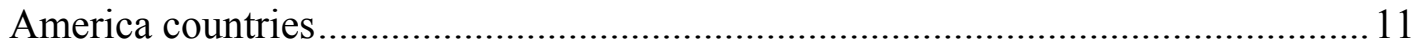

Table 3: Use of traditional easements for conservation purposes by 2002 ............................ 12

Table 4: Some examples of land use restrictions for environmental purposes ........................16

Table 5: Extent of mixed public-private protected areas private lands .................................17

Table 6: Principal characteristics of the ecoregions and sub-ecoregions of the study area.......34

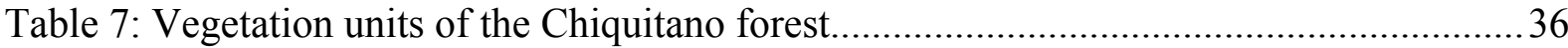

Table 8: Vegetation units of the Cerrado of the Chiquitano Region ........................................ 37

Table 9: Identified vegetation units and estimated units in the study area.............................50

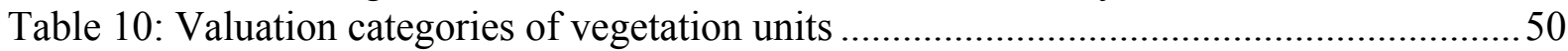

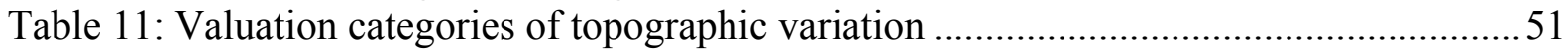

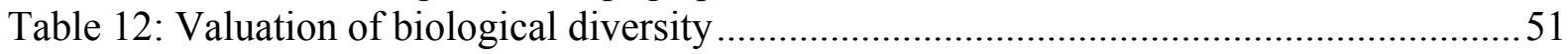

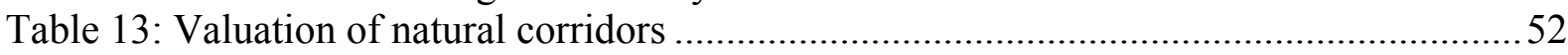

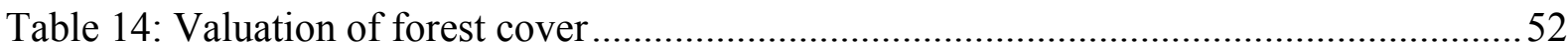

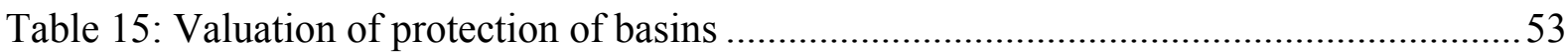

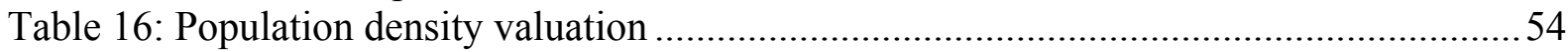

Table 17: Criteria and categories for the valuation of the impact of roads ...........................55

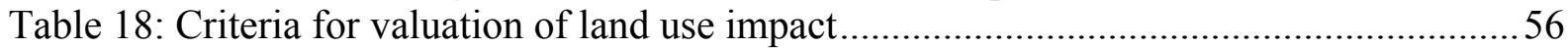

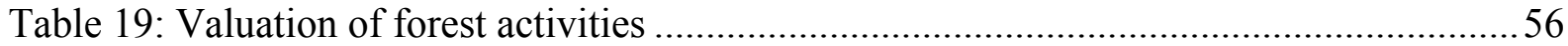

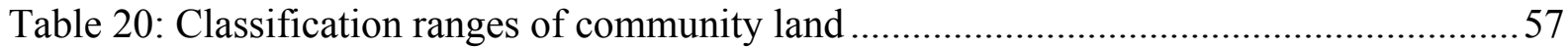

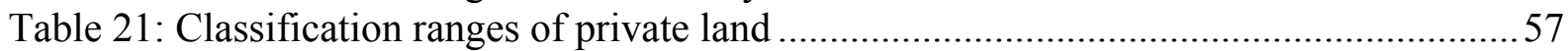

Table 22: Classification criteria of the biological-ecological valuation...................................58

Table 23: Classification criteria of the conservation status ....................................................58

Table 24: Ranges and criteria for spatial conservation priorities ........................................59

Table 25: Codification, surface and location according to conservation priorities of holdings

Table 26: Features of ecoregions presented in the selected ranches .......................................63

Table 27: Number of selected ranches according to the land tenure category .......................63

Table 28: Registered and estimated vascular plant diversity for the study area and adjacent

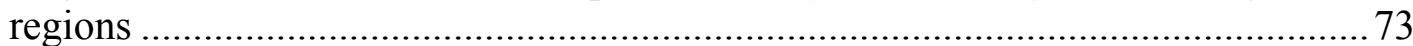

Table 29: Diversity of birds and mammals of the study area and adjacent areas....................73

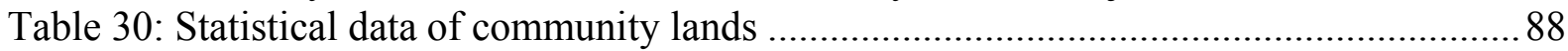

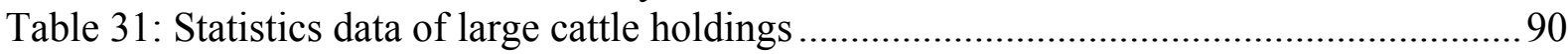

Table 32: Surface and percentage of land use categories in the study zone according to the General Land Use Plan of Santa Cruz Department .................................................99

Table 33: Surface and percentage of areas with legal use restrictions according to the Bolivian

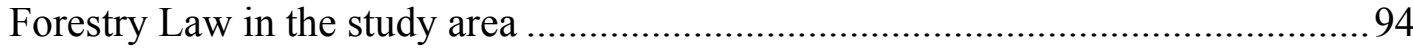

Table 34: Surfaces (ha) of land use under traditional farming. Holdings in the Chiquitano Forest ecoregion in the year 2002 ....................................................................... 104

Table 35: Number of species and families registered in rapid biological assessments in holdings of the ecoregion Chiquitano Forest.

Table 36: Surfaces (ha) of land use under traditional farming. Holdings with characteristics of the ecoregions Chiquitano Forest and Cerrado in the year 2002

Table 37: Number of species and families registered in rapid biological assessments in holdings with characteristics of the Chiquitano Forest and The Cerrado ecoregions 
Table 38: Surfaces (ha) of land use under traditional farming. Holdings in Flooded Amazon Savannas ecoregion, year 2002

Table 39: Comparison of the number of species and families registered in rapid biological assessments in the holdings of the Flooded Amazon Savannas and the registered species of the Noel Kempff National Park

Table 40: Surfaces (ha) of proposed land-use categories in the holdings of the Chiquitano Forest ecoregion

Table 41: Surfaces (ha) of proposed land-use categories in holdings with characteristics of the ecoregions Chiquitano Forest and Cerrado

Table 42: Surfaces (ha) of proposed land-use categories in holdings of Flooded Amazon Savanna ecoregion

Table 43: Summary of the proposed management plans of natural private reserves

Table 44: Result of the legal process of governmental recognition of proposed land-use and management plans

Table 45: Proposed distances for compulsory protection areas in the zone of study............ 144

Table 46: Scenarios of private land conservation in the short-term ...................................... 150

Table 47: Scenarios of private land conservation in the long-term ...................................... 150 
Dedicated to

Roxana

The Lord's expression of his love for me 


\section{Acknowledgements}

I received support of many persons and institutions to accomplish this work, I greatly appreciate what they have done for me. Specifically, thanks...

To Prof. Dr. Gerhard Gerold, head of the Department of Landscape Ecology, University of Göttingen, who was the main supervisor of my study. Thanks Prof. Gerold to give me always words of encouragement during my studies in Germany.

To Prof. Dr. Pierre Ibisch of the University of Applied Sciences Eberswalde and former head of the Scientific Department of FAN-Bolivia foundation. As foreign expert in Bolivia, he has shared his scientific knowledge and compromise for biodiversity opening a new perspective of the conservation inmy country. I want to express my acknowledgements for his scientific advice and his friendly words of motivation.

To the FOUNDATION FOR THE CONSERVATION OF THE CHIQUITANO FOREST for the economic, technical and scientific support. I would like to express gratitude to Mr. Hermes Justiniano, head of the foundation, and Dr. Roberto Vides, scientific coordinator, who gave me their confidence to continue and to finish this research.

To the team of "The friends of nature Foundation (FAN-Bolivia)", who provided me varied support and the possibility to develop an empirical experience in the main topic of this study. In particular, thanks to Richard Vaca, Steve Eguino and the colleges of the UCP.

To all the private landowners who took part in this study, in particular, who have chosen, from their heart, to seek to conserve the natural resources, nature, and beauty of their land.

To the Servicio Nacional de Reforma Agraria, Agrarian and Forestry Superintendence, San Ignacio Municipality, MINGA and the Museo de Historia Natural Noel Kempff Mercado, for the different data used in the study.

To Mario Catari, who helped me in the data collection as well to Jaime Quispe, my friends for ever. Also I want to thank Jens-Peter Krueger for his permanent support as well as the collegues of the Department of Landscape Ecology.

My acknowledgments to my friends: Alexandra Ley, who had the difficult mission to review the first version of this study, Mr. Reynaldo Palomino for all suggestions and a special thanks to Kirsten Pöhlker for reading and correcting this document.

I would like to express special thanks to my wife Roxana for her support, confidence and love during this time, to whom this thesis is dedicated. To my parents Luis and Juana as well as to my brothers and sisters for encourage my academic career. To the Christian Group for their friendship, and all my friends in Germany, Bolivia who believe in this effort

Finally, I want to thank the Lord for His blessing, His Word and His love during these years. He has opened a lot of doors to support this work. 


\section{Abstract}

This study discusses the advantages and constraints of the involvement of private landowners in biodiversity conservation as well as the measures and strategies to accomplish this task. The area studied is an important place for the connectivity of the Chiquitano forest, an ecosystem that exists only in the tropical lowlands of Bolivia. Almost $68 \%$ of the study area still stands out for its very good conservation status and about $20 \%$ of the area studied has been prioritised for protection in order to maintain the connectivity between Chiquitano Forest and Amazon Forest. This surface is mainly in the hands of private landowners, who use it mainly for cattle production. A case study of landowners whose holdings are located in the area with priority for conservation suggests that the proprietors' predisposition to protect wildlife on their land is relatively good, but it faces constraints that disappoint the initial owner interest. Half of the landowners studied had expressed interest in establishing private reserves; but most of them were discouraged due to the legal requirements (in particular land tittles), bureaucratic procedures and the apparent non-existence of economic benefits; however, as a promising exception, it was observed that some proprietors are already implementing some kind of conservation measures and are willing to take part in a more formal process of wildlife conservation despite the problems mentioned. On other hand, the proprietors that prefer to use their land only for production purposes probably represent the greater number of landowners in the region and it must be considered that they will demand extra benefits if they agree to set aside areas for biodiversity. As a practical result, in this research, it has been proved that technical support for land use planning, as an incentive, is a real and viable alternative for encouraging private land conservation. Land-use plans carried out in an ecological perspective open possibilities for conservation not only through areas for strict conservation but also introduce measures such as limited/controlled forest production, the establishment of forest reserve areas, wind belts and protected forest river margins, which could contribute to the conservation issues. These former aspects are very important, particularly for working with landowners who do not want to establish protection areas voluntarily. The study showed three major constraints: (a) the unsolved land property situation, (b) the lack of effective incentives to promote conservation and (c) land policies that indirectly push landowners towards the conversion of natural ecosystems, but, in contrast to that, factors such as (a) the good conservation status, (b) the low population density of the zone and (c) the owners' need for land use options- in a place which still has low opportunities of development- induce one to continue the efforts towards an active and socioeconomic viable participation of landowners in conservation. In this way, some recommendations can be given. Thus, the implementation of incentive-based projects that provide technical support and social recognition for the efforts of conservation may be the first stage in a long-term private conservation process. Indeed, the development of new incentives (payment for environmental services, evaluation of forest and ecotourism) has to be considered the key for achieving successful results. In addition, in order to achieve long-term advantages, immediate and structural policy changes are needed, which can be accomplished only with agreement between government and civil society. Finally, it must be mentioned that the traditional approach to implementation of biodiversity conservation on private lands (or the setting aside of areas for wildlife) does not appear to be enough to ensure the protection of ecosystems and the connectivity in the study zone, but it has a high potential of contribution if it should be considered as complementary measure in a major conservation strategy that integrates conservation in national/municipal protected areas, sustainable forest use and development of non-agricultural sources of goods. 


\section{Zusammenfassung}

Die Studie bespricht die Vorteile und Begrenzungen der Einbeziehung von privaten Grundbesitzern im Naturschutz sowie die Maßnahmen und Strategien, diese Aufgabe zu bewältigen. Das Studiengebiet liegt in einer für die Konnektivität des Chiquitano Waldes wichtigen Region, ein Ökosystem, das nur in den tropischen Tiefländern von Bolivien vorkommt. $68 \%$ des Studiengebietes weisen noch einen sehr guten Erhaltungsstatus auf und 20\% der studierten Region sind als prioritäre Gebiete für den Naturschutz ausgewiesen, um die Konnektivität zwischen Chiquitano und Amazonas Wald aufrecht zu erhalten. Diese Fläche ist hauptsächlich in den Händen vom privaten Grundbesitzern, die das Land zur Viehproduktion benutzen. Eine Fallstudie an mehreren Grundbesitzern mit unterschiedlichen Vorraussetzungen, deren Eigentum im priorisierten Bereich liegt, zeigt, dass die Prädisposition der Eigentümer naturnahen Ökosysteme auf ihrem Land zu schützen gut ist. Diesem Ausgangsinteresse stehen allerdings gewisse juristische Restriktionen gegenüber, die die Grundbesitzer enttäuschen. Die Hälfte der Befragten hatte Interesse gezeigt, ein privates Reservat einzurichten; aber die meisten von ihnen wurden durch die gesetzlichen Anforderungen (insbesondere Land Besitztitel), die bürokratischen Verfahren und das offensichtliche Nichtvorhandsein eines ökonomischen Nutzens entmutigt; als vielversprechende Ausnahme wurde jedoch beobachtet, dass einige Eigentümer bereits irgendeine Art von Erhaltungsmaßnahme eingeführt haben und bereit sind, trotz der erwähnten Probleme, an einem formaleren Prozess des Naturschutzes teilzunehmen. Dennoch sind wahrscheinlich diejenigen Eigentümer, die ihr Land nur zu Produktionszwecken nutzen wollen, vermutlich in der Überzahl in der Region und es muss beachtet werden, dass sie gewisse ökonomische Anreize verlangen, um Bereiche ihres Landes für den Schutz von Biodiversität einzusetzen. Ein praktisches Ergebnis dieser Forschung ist, dass Anreize, wie die technische Unterstützung in der Landnutzungsplanung, reale und entwicklungsfähige Alternativen für die Anregung des privaten Naturschutzes sind. Landnutzungspläne, die vor dem Hintergrund ökologischer Wertschätzung erstellt wurden, öffnen neue Möglichkeiten der Erhaltung nicht nur im Rahmen vollkommener Unterschutzstellung ohne jegliche Nutzungsmöglichkeiten, sondern auch durch integrative Maßnahmen wie die begrenzte Waldproduktion, die Einrichtung von Waldreservebereichen, Windschutzgürtel und geschützter Waldflussseitenränder. Diese zuletzt genannten Maßnahmen konnten zur Erhaltung beitragen und werden besonders in der Arbeit mit Grundbesitzern wichtig, die nicht freiwillig Schutzgebiete einrichten möchten. Die Studie zeigte drei Hauptbeschränkungsfaktoren für die Errichtung von Schutzgebieten auf Privatgrund: (a) die ungelöste legal Grundbesitzsituation, (b) der Mangel an wirkungsvollen Anreizen sowie (c) politische Richtlinien, die indirekt Grundbesitzer in Richtung der Umwandlung der natürlichen Ökosysteme zu Agrarland drücken. Im Gegensatz dazu stehen allerdings (a) der gute Erhaltung Status von weiten Teilen der Region, (b) die niedrige Bevölkerungsdichte der Zone und (c) die Bereitschaft der Eigentümer zur Betrachtung von alternativen Landnutzungsoptionen, die eine Fortsetzung der Bemühungen zur Integration privater Grundbesitze in Naturschutzkonzepte rechtfertigen. Auf der Basis dieser Analyse können einige Empfehlungen gegeben werden. So könnte die Durchführung eines Anreiz-begründeten Projektes, die Bereitstellung der technischen Unterstützung und die sozialen Anerkennung der Naturschutzbemühungen, ein erster Schritt in einem längerfristigen privaten Erhaltungsprozess sein. Dennoch es ist in der Tat nötig, die Entwicklung der neuen Anreize (z.B. Zahlung für Klimadienstleistungen, Auswertung des Waldpotentiales und Etablierung von Öko-Tourismus). Zusätzlich sind für einen längerfristigen erfolgreichen Naturschutzprozess Änderungen der Strukturpolitik erforderlich, die nur mit Vereinbarungen zwischen Regierung und Zivilgesellschaft vollendet werden können. Schließlich soll allerdings bemerkt werden, dass die Errichtung privater Schutzgebiete zur Biodiversitätserhaltung alleine als nicht ausreichend zu betrachten ist, den Schutz der Ökosysteme und der Konnektivität im Studiengebiet sicherzustellen. Aber es kann einen wichtigen Beitrag zum Schutz von Schlüsselgebieten leisten. So sollte diese Art des Naturschutzes als ergänzende Maßnahme in einer Haupterhaltungsstrategie betrachtet werden, die in der Erhaltung durch staatliche Schutzgebiete, der Durchführung nachhaltiger Waldwirtschaft und der Entwicklung von nicht landwirtschaftlichen Arbeitsplätze besteht. 


\section{INTRODUCTION}

\subsection{Argumentation and antecedents}

Bolivia is one of the 15 most biodiverse countries in the world (UN 2002, 2002a and Biodiverse online 2004) and is designed as a global priority for conservation actions. More than half of the Bolivian territory (58\%) still presents a good conservation status (Ibisch et al. 2004). However, the destruction of forest and the loss of biodiversity is increasing due to settlements, the agricultural frontier, and industrial development (Gerold 1983 and 2004, Ibisch 2004, 2004a, Pacheco \& Mertens 2004, Steininger et al. 2001).

Nowadays the System of the National Protected Areas of Bolivia covers 17\% of the territory, but this area is not enough to protect all natural values (MDSP 2003, Ibisch 2004b, Rivera 2004). In addition, some protected areas are dispersed and without connections, therefore these areas are under threat to become islands that do not guarantee the protection of natural values in the long term.

The deciduous Chiquitano Forest, a wide area of thousands of square kilometres of natural habitat, which exists only in Bolivia, is just one example of an area with urgent conservation needs. The larger part of this forest lies outside of national protected areas and there are few possibilities to establish any big protected area there, therefore it should be protected by different conservation mechanisms. The Chiquitano Forest was almost intact until the ends of the 1990s; since then, strong economic processes have affected it. In 2000, the construction of a controversial gas pipeline across the Chiquitano Forest caused protests of many groups of the civil society and promoted the formation of the Foundation for the Conservation of the Chiquitano Forest (FCBC) in order to support the preservation of this important ecosystem. FCBC planned and financed the design of the "Plan for the Conservation and Sustainable Development of the Chiquitano Dry Forest, Pantanal and Bolivian Cerrado (PCSD)" (Ibisch et al. 2002). The main purpose of this plan was to give an overview of the resources of this area and their value in order to maintain the forest and its associated regions and to prevent environmental impacts from regional development and from major projects of infrastructure executed in the area (FCBC online 2004).

The "Conservation Plan" was published in 2002 and recommended a set of conservation actions considering the socio-economic situation of the region. One of the major recommendations is the development of alternative mechanisms to achieve biodiversity 
conservation on private land, in particular in the transitional region between the Chiquitano Forest and the Amazon Forest. Hence, the present study was carried out to evaluate the potential and viability of biodiversity conservation on private land in order to set into action that recommendation.

The study area, recommended by the "Conservation Plan", is located in the East of the department Santa Cruz, in the lowlands of Bolivia. This is an important and strategic place for conservation: it is one of the last places of the transitional region between deciduous/semideciduous and Amazon forest, which has little human impact and still allows the natural connectivity to link both forests. This quality has a significant value for the Chiquitano forest to anticipate the negative effects of climate change. Furthermore, the conservation of the mentioned area will prevent the isolation of the Noel Kempff Mercado National Park, declared as a world heritage by the UNESCO, located in the north of the department.

The content of this research presents a topic which has not yet been sufficiently studied in Bolivia: the direct participation of the civil society in the conservation of natural flora, fauna and landscapes. The study emphasises land planning as the main tool to promote conservation linking social and ecological aspects. A general view of the results shows that the private landowners' acceptance to take part in the efforts to maintain natural values is limited, but it does not seem to be impossible to reach a certain degree of protection through private participation if government and institutions adjust certain environmental politics and procedures.

Several social conflicts in Bolivia have occurred during the accomplishment of this study, some of them related to the unequal distribution of the land, which has a direct relation to the main topic of this study. This situation shows the need of more methodologies to achieve deals and consensus with regard to the use of natural resources. In this context, the study offers some inputs to support the search of ways to conduct conservation in accordance with the society.

\subsection{Questions of the study}

Since 1994, Bolivia has established the concept of participation as a basic policy in order to address their development. Consequently, there is already a legal framework that allows the direct involvement of every citizen in the management and sustainable use of natural resources and in the management of biodiversity, however, up to now this potential has not been sufficiently applied to improve the Bolivian conservation issues. 
In some countries good examples exist that show a positive and active integration of private landowners in nature conservancy. In the United States, the private sector protects through different measures thousands of hectares of land (LTA online 2004), private natural reserves have strengthened the systems of national protected areas since the 1990s in Latin America and The Caribbean (ELI et al. 2003). In the case of Bolivia, a first study about the success of the establishment of private reserves has demonstrated that some groups of private landowners have protected wild areas without formal support (Choquehuanca 2001). Therefore, it seems promising to invest resources and efforts to elaborate a compendium of the possible advantages of conservation on private lands, in particular considering that the human pressure is the main reason for the destruction of biodiversity and up to now there were practically no efforts to explore conservation opportunities outside of protected areas (Ibisch 2004b).

Biodiversity conservation on private land has to be part of major national and international strategies in order to contribute efficiently to wildlife protection (Norton \& Miller 2000). With regard to Bolivia, the private initiatives should strengthen the National System of Protected Areas through (a) the formation of natural corridors between large protected areas, (b) the conservation of natural values- which are outside of the state protection measuresand (c) the amelioration of buffer zones. But at the same time, private land conservation should offer options for the landowners who want to participate in wildlife protection.

In this context, the following main question was designed in order to analyse the case of the Transitional Region Chiquitano-Amazon (TR-CHA)

\section{What are the potential advantages and constraints of the development of biodiversity conservation on private land in the transitional region Chiquitano-Amazon?}

To answer the above-mentioned question the following specific questions were formulated:

- How is the conservation status of this region and which are the places with high conservation priority?

- Are the landowners willing to establish private reserves on their ownerships to protect biodiversity? Which factors are crucial/decisive?

- Which are the recommendations to promote the conservation on private land that should complement the major processes of conservation, carried out in national protected areas? 


\section{LITERATURE REVIEW}

\subsection{The paradigm of private land conservation and its contribution to the conservation biology goals}

Since the creation of the first National Park in the USA in the year 1872, the establishment of protected areas has been the main state strategy for biodiversity conservation. In 2003 the World Commission on Protected Areas reported that globally protected areas covered up to 18,8 million of $\mathrm{km}^{2}$ (12.65\% of the Earth's land surface) and the majority of protected areas had been established after the Earth Summit in Rio de Janeiro in 1992 (Chape et al. 2003). Furthermore, they state that a greater increase will not be possible in the future because of the general socio-economic conditions. For this reason alternative mechanisms and instruments have to be developed for protection of biodiversity outside of national protected areas. The conservation on private land or private land conservation could be one of the real alternatives (Choquehuanca 2003 and 2004).

Conservation on private land should be defined as a set of initiatives and actions to preserve natural values located on private ownerships. This kind of conservation is not, contrary to popular opinion, a twentieth century invention (Levitt 2001). A lot of private efforts, which have not yet been studied sufficiently, have already contributed substantially in different ways to the conservation of the world's biodiversity and they have an unexplored potential to complement and strengthen the national systems of protected areas (ELI et al. 2003).

In the last decade, several institutions have been working to promote conservation on private land as an alternative to complement national conservation efforts. In the first steps, the private efforts have focused on land purchase and land stewardships as central tools for conservation (LTA online 2000, Czech 2002). These ways have sometimes been successful in a certain context, however, the conservation on private land is not only the simple isolation of certain wild areas, especially in places with social problems and conflicts, as it is the case in Bolivia. In recent years, voluntary deals with private landowners, achieved using incentives, have been the most successful instruments.

The contribution of private land conservation to biodiversity conservation is not yet wellknown because little effort has been given to systematise the outcomes in this work (Merenlender et al. 2004). Some examples of private land conservation and their contribution 
to national conservation are discussed in the following paragraphs comparing developed and developing countries.

The USA is one of the countries where the conservation on private land is well-developed. Some of the first private initiatives to protect nature occurred in the 18th century (Levitt 2001). More organized and systematised works have been made since the 1960s. Private conservation groups, called "Land Trusts", promoted private land conservation through land purchases, land stewardships and conservation easements. The Land Trust organizations currently protect 6.2 million acres (LTA online 2002). However, according to Merenlender et al. (2004), it is difficult to determine exactly the whole contribution of Land Trusts' works to the conservation in the USA because "easily available information on protected resources it too aggregated to determine what is actually being conserved, and more detailed data is widely scattered and hence difficult to synthesize". It shows problems of coordination and interchange of information among these conservation institutions. A study carried out on private lands in USA reports that these lands harbor a great amount of biodiversity, including $95 \%$ of the federally listed species, which shows the importance of conducting conservation researches and measures on these areas (Hilty \& Merenlender 2003).

Another example of conservation on private lands has been developed in Australia, where 14 million hectares are protected in more than 600 private reserves (Fundación Bertoni 2000, Latrina et al. 2000, Australian Bush Heritage online 2004). The private land conservation has a major significance for example to manage the Koala, which is one of the Australian key species (Lunney et. al. 2000).

Both the USA and Australia have a clear land property right situation and a clear legal framework which allow the development of private conservationists' proposals. This is a mayor difference to experiences with conservation in developing countries like in Latin America.

In Latin America countries, the private conservation movement has been promoted by international NGOs like The Nature Conservancy (TNC) and Conservation International (CI). These institutions have imported their methods and conservation visions but they have also developed new manners in associating with local partners.

In Paraguay at the beginning of the 1980 s, only $3 \%$ of the total surface was protected and $95 \%$ of the national territory belonged to private landowners. For this reason TNC and Fundación Bertoni (a local NGO) in alliance with the Paraguay Government have promoted the establishment of private reserves in order to save threatened natural areas. By the end of 
2000 , private reserves covered already 134,008 ha ( $0.3 \%$ of the country), but the general objective of these measures was to cover about $10 \%$ of the whole territory. A report on 10 years of the Bertoni Foundation's work mentioned that the main problems for private land conservation are: (a) existence of an inadequate law and the obstacles to applying it, (b) concern about the invasion of land considered without use, (c) unplanned expropriations of private land in order to support farmers without land, (d) the lack of incomes to manage private reserves, (e) illegal hunting and extractions of natural values, (f) absence of environmental education, and $(\mathrm{g})$ the lack of technical support to the landowners. In spite of those problems, one of the most important results of these projects was the introduction of private land conservation into the national System of protected areas (Fundación Bertoni 2000)

Among the countries of Latin America Costa Rica is first in the development of measures to protect the environment and biodiversity. Their solid system of protected areas, the innovative mechanisms to pay for environmental services of forests (PES) and the modern infrastructure for eco-tourism are well-known. In this country, conservation on private land has been developed successfully by non-governmental institutions. In 1992 CEDARENA, a Costa Rica NGO, explored, for the first time ever in Latin America, the possibility to protect lands in perpetuity using conservation easements. That same year the first ecological easement was created in Costa Rica (CEDARENA online 2004). Since then this organization has promoted the diffusion of conservation easements and it has had good outcomes, but the area protected on these initiatives is small (less than $0.1 \%$ of the country's territory, see table 4). Nevertheless their results are qualitatively significant because the conservation easements assure a long-term protection of some endangered areas.

Other alternatives to protect nature on private land in Costa Rica have managed to cover more surfaces, especially the creation of forest reserves and forest management areas that were promoted by the payment for PES. The inversion of 80 millions dollars allowed the protection of 300,000 ha of forest (Rosa et. al. 2003).

Another examples show the first steps of the work with peasants and indigenous people. In Colombia, for instance, the "RECSA" has promoted the conservation of natural landscapes and forest stressing social participation. Their results are currently not very extent in surface $(40,000$ ha, $<1 \%$ of Columbian area) but it promoted a social vision of nature (RESNATUR online 2004). In the same way, PRONATURA AC is working with indigenous people searching a common vision for the preservation of natural resources (PRONATURA A.C. online 2004). 
As can be seen from the mentioned experiences, private land conservation started only recently in Latin America and although to date its contribution is small in terms of surface, its potential to support conventional conservation is very high.

\subsection{Methods and incentives to protect private land in the context of Latin America}

Although conservation on private land has been carried out for a long time, the attempts to formalize it using legal and administrative frameworks are relatively recent. The efforts of private land conservation apply methods and tools that can be classified in 2 groups: voluntary methods, which depend on the independent landowner's decision, and compulsory restrictions, which normally express state restrictions in order to protect natural values protection as soil, water and wildlife.

\subsubsection{Voluntary methods}

According to Chacon et al. (2000), the main condition to carry out private land conservation is the landowner's will to do it. However, legal tools are needed to formalize and to ensure the fulfilment of voluntary decisions. Chacon adds that the use of legal tools for conservation provide: compromise, permanency, clear rules and incentives.

Although the use of legal tools is the main way to carry out conservation on private lands, there are some conservation experiences mentioned by Choquehuanca (2001) and ELI et al. (2003) that were undertaken without use of these tools. Therefore, voluntary methods include not only the use of legal tools but also private deals and pacts recognized by social groups. In the following section, voluntary tools are described.

\section{a. Land purchase and ownership by conservation NGOs}

"The most frequently used voluntary land conservation technique in Latin America has been ownership of property by a non-profit organization dedicated to land conservation". "This form of ownership provides long-term conservation protection, as NGOs are legally obligated to follow the objectives defined in their status, which may only be changed through a process involving judicial scrutiny. Another advantage of this method is that NGOs tend to protect lands of conservation importance, whereas decisions by private landowners tend to be more haphazard" (ELI et al. 2003). 
Some notable NGO conservation successes in land conservation include the creation of the 30,500 ha cloud forest reserves in Monteverde, Costa Rica, the largest private reserve in Central America (see box 1), as well as the initiative to conserve the large Guanacaste Conservation Area (Costa Rica) through a public-private partnership (AGG online 2004). In South America, the largest reserve is the vast 300,000 ha Pumalin Reserve in Chile (Parque Pumalin 2004) created by the Conservation Land Trust, which is also creating a similar-sized reserve in Corrientes, Argentina. A few corporations have also been active in large-scale private lands conservation. The 22,000 ha Linhares Nature Reserve is protected by the Companhia Vale do Rio Doce in Brazil, and the 33,000 ha Sierra del Carmen Reserve in Mexico by CEMEX. In Brazil, 19,000 ha are protected in a collaborative arrangement by local and international NGOs, with funding from U.S. corporations to offset their carbon emissions (ELI et al. 2003).

\section{BOX 1. Monteverde cloud forest History}

In 1972 under the threat of homesteading in the surrounding rain forest, visiting scientists George Powell and his wife joined forces with long-time resident Wilford Guindon to promote the establishment of a nature preserve. The Tropical Science Center was receptive to these efforts and accepted institutional responsibility for ownership and management of the protected areas. An initial land purchase of 328 hectares formed the core of the Monteverde Cloud Forest Preserve, Costa Rica.

In 1975 the 554-hectare community watershed reserve, founded in the mid-60s by members of the Quaker community and named Bosque Eterno S.A., was annexed under an administrative contract to the Preserve. After the Preserve's creation, the Tropical Science Center continued to secure the financial and human resources necessary to expand, consolidate, and properly protect and manage the Rainforest Preserve's current 10,500 hectares. (Monteverde online 2004)

As stated by ELI et al. (2003) "the principal limitations on the use of land purchase as a conservation tool are the high cost of acquisition and the ongoing responsibility of private entities to raise the necessary funds for stewardship and protection. For these reasons, land purchase is perhaps most important for the conservation of critically endangered ecosystems where the need to protect and expand small areas is greatest". However, this statement does not consider that the land purchase in areas with high poverty and colonization, in spite of the lower price, represents a great problem. According to the experience of FAN-Bolivia, the socio-economic conditions should be considered to define potential areas for land purchase (Choquehuanca 2001; Choquehuanca \& Eguino 2003). 


\section{$\underline{\text { b. Private reserves }}$}

The establishment of private reserves has been a common method to protect biodiversity in Latin America (see table 1). "A private reserve is a natural area with restrictions of use, which are voluntarily established by a landowner based on legal frameworks. The government play a major role in this method because it gives its approval to the owners' proposition and has to give legal guarantees and incentives for that. Normally the owners' commitment to conservation has a defined period of time. One of the main legal characteristics of private reserves is that it is the landowner who has legal obligations with the government. This means there are no obligations related to the land as such" (ELI et al. 2003).

A good attempt to describe the situation of private reserves was done by eight nongovernmental institutions in the publication "Legal tools and incentives for private lands conservation in Latin America" (ELI et. al. 2003). Table 1 presents an adapted summary of those results in order to shows the total amount of surface. It can be seen from this table that Brazil, Chile, Ecuador and Costa Rica have bigger numbers of private reserves and more covered area than other countries. This can be explained by the fact that more facilities and incentives are given by the laws and administrative systems of the mentioned four countries (see table 2). In addition, the influence and work of conservationist NGOs has played a main role in the mentioned countries. However, remarkable non-governmental efforts have been carried out in some countries in which there are no official legal framework for private conservation, for instance, the "Fundación de Vida Silvestre" has built a network of private reserves with interesting results in Argentina (see table 1 and 2).

ELI et al. (2003) add in their study that "the advantages of using private reserve designation to protect lands include: (a) it creates greater juridical security of land tenure because governmental approval of private reserves recognizes the property's importance and endorses the proposed land use as a valid socio-economic use, (b) avoiding problems with land tenancy laws; (c) provides a basis and structure for the provision of government financial, technical or other incentives by determining the lands to be of priority value; and (c) helps to assure continued compliance with the conservation objectives of the designation, through a government monitoring process". 
Table 1: Number and surface (ha) of private reserves in some Latin America countries

\begin{tabular}{|l|l|l|l|}
\hline Country & Denomination & Number & Hectares \\
\hline 1. Argentina* & Wildlife reserve RVS & 14 & 50,000 \\
\hline 2. Brazil & $\begin{array}{l}\text { Private reserves of natural patrimony } \\
\text { RPPN) }\end{array}$ & $\begin{array}{l}367 \text { Federals }(405,114 \\
\text { ha), 192 states }(82,117 \\
\text { ha) }\end{array}$ & 487,231 \\
\hline 3. Chile** & Private protected areas APP & $133^{* *}$ & 376,552 \\
\hline 4. Colombia & RRNSC & 164 & 35,000 \\
\hline 5. Costa Rica** & Private national wildlife refuges RVS & $58 * *$ & 180,035 \\
\hline 6. Ecuador & Bosque protector BP & $\begin{array}{l}88 \text { public }(113,683 \text { ha) } \\
\text { and 3 mixed }(104,421)\end{array}$ & 218,104 \\
\hline 7. Guatemala & Private natural reserves & 51 & 21,697 \\
\hline 8. Mexico & Private reserves & 1 & 13,500 \\
\hline 9. Paraguay*** & Private reserves & 4 & 103,464 \\
\hline 10. Peru & Private conservation areas & 1 & 34,000 \\
\hline
\end{tabular}

**In Chile and Costa Rica, the land data for formally designated reserves combines data for statedeclared reserves.

*** Paraguay has a private reserves law, but there is a no formal system of private reserves (not considered in the table).

Sources: 1. FVSA online 2004, 2. Fundación O Boticario de Protección a la Naturaleza 2003, 3. CODEFF 2003 and CODEFF online 2004, 4. RESNATUR online 2004, 5. CEDARENA 2003, 6. CEDA 2003, 7. Fahsen \& Macorra 2003, 8. PRONATURA AC 2003, 9. SPDA 2003, ELI et al. 2003.

On the contrary, ELI et al. (2003) mention that private reserves have a number of strengths as well as limitations that affect their potential use: "First, they must be recognized by a government entity as having special value for conservation, which provides government endorsement, but also limits the opportunity to create them. Second, the designation imposes a number of land use restrictions and procedural requirements that obligate the owner of the private reserve to develop and follow a management plan, and make annual reports to the government. These restrictions tend to make private reserves a tool used for strict conservation purposes. Private reserves therefore fall somewhere between a voluntary land conservation practice of private landowners, and a form of land management similar in some ways to the operating concepts of larger national parks".

The mentioned description of limitations stresses a supposed excessive government intervention as a negative obstacle for the diffusion of private land conservation. However, this assumption might be discussed considering the need that the conservation measures 
complement the national strategies of conservation and the necessity of regulations and controls to avoid the use of this mechanism to break up the rules.

Table 2: Summary of legal framework and incentives of private reserves in some Latin America countries

\begin{tabular}{|c|c|c|c|c|}
\hline Country & Denomination & Legal framework & Incentives & $\begin{array}{l}\text { Term of } \\
\text { protection }\end{array}$ \\
\hline 1. Argentina & $\begin{array}{l}\text { Wildlife reserve } \\
\text { RVS }\end{array}$ & no & Institutional support & $\begin{array}{l}\text { Depends on the } \\
\text { deal with the } \\
\text { landowner }\end{array}$ \\
\hline 2. Brazil & $\begin{array}{l}\text { Private reserves } \\
\text { of natural } \\
\text { patrimony } \\
\text { (RPPN) }\end{array}$ & $\begin{array}{l}\text { Federal and state } \\
\text { forest law }\end{array}$ & $\begin{array}{l}\text { Exemption from tax } \\
\text { payment }\end{array}$ & Perpetual \\
\hline 3. Chile & $\begin{array}{l}\text { Private } \\
\text { protected areas } \\
\text { APP }\end{array}$ & $\begin{array}{l}\text { Environmental law } \\
\text { and private accords }\end{array}$ & $\begin{array}{l}\text { Institutional NGO } \\
\text { support }\end{array}$ & $\begin{array}{l}\text { Depends on the } \\
\text { deal with the } \\
\text { landowner }\end{array}$ \\
\hline 4. Colombia & Private reserves & Environmental law & $\begin{array}{l}\text { Institutional NGO } \\
\text { support }\end{array}$ & \\
\hline 5. Costa Rica & $\begin{array}{l}\text { Private national } \\
\text { wildlife refuges } \\
\text { RVS }\end{array}$ & $\begin{array}{l}\text { Wildlife } \\
\text { conservation law }\end{array}$ & $\begin{array}{l}\text { Payment for } \\
\text { environmental services } \\
\text { Exemption from } \\
\text { payment of rural taxes }\end{array}$ & \\
\hline 6. Ecuador & $\begin{array}{l}\text { Bosque } \\
\text { protector BP }\end{array}$ & $\begin{array}{l}\text { Forestry and } \\
\text { conservation of } \\
\text { natural areas and } \\
\text { wildlife law } \\
\end{array}$ & $\begin{array}{l}\text { Exemption from } \\
\text { payment of rural taxes }\end{array}$ & \\
\hline 7. Guatemala & $\begin{array}{l}\text { Private natural } \\
\text { reserves }\end{array}$ & Protected areas law & no & \\
\hline 8. Mexico & Private reserves & $\begin{array}{l}\text { Federal general law } \\
\text { for ecological } \\
\text { equilibrium and } \\
\text { environmental } \\
\text { protection }\end{array}$ & not developed $(*)$ & \\
\hline 9. Paraguay & Private reserves & Protected areas law & & \\
\hline 10. Peru & $\begin{array}{l}\text { Private } \\
\text { conservation } \\
\text { areas }\end{array}$ & $\begin{array}{l}\text { Law on national } \\
\text { protected areas }\end{array}$ & technical assistance $(*)$ & \\
\hline
\end{tabular}

(*) Incentives in fact not available

Sources: 1. FVSA online 2004, 2. Fundación O Boticario de Protección a la Naturaleza 2003, 3. CODEFF 2003 and CODEFF online 2004, 4. RESNATUR online 2004, 5. CEDARENA 2003, 6. CEDA 2003, 7. Fahsen \& Macorra 2003, 8. PRONATURA A.C. 2003, 9. SPDA 2003, ELI et al. 2003. 


\section{$\underline{\text { c. Conservation easements }}$}

Conservation easement has been applied in Latin America since 1992 (see table 3). LTA online (2000), ELI et al. (2004) and CEDARENA (2000) agree in the definition of conservations easement as a voluntary (legal) agreement in which a landowner agrees to limit the use of property, and which can be created for a term of years or for perpetuity, depending on the country. They can be used for conservation purpose by limiting the rights to use land in certain ways or the intensity of development, in order to conserve natural features of the land.

This conservation method is mainly a private settlement; it has the advantage that complex procedures, asked by government offices, are not required. Another characteristic is that the easements establish a direct and legal bind to the land; in certain countries it can be used to assure the protection for eternity (CEDARENA 2000).

Table 3 shows a summary of NGOs' work to apply easements to countries in Latin America until 2002. It can be seen that the covered area is relatively small. Costa Rica shows the highest number of easements but Guatemala has the bigger surface of protected land due this tool.

The main barriers to spread the use of easements are legal limitations, the lack of clear land titles and uncertain enforcements (ELI et al. 2003). In 2002 a very strong criticism was published in the USA, because of the discovery of the illegal use of the easement to avoid land taxes ${ }^{1}$.

Table 3: Use of traditional easements for conservation purposes by 2002

\begin{tabular}{|l|l|l|l|l|}
\hline Country & Lead organization & $\begin{array}{l}\text { Year of first } \\
\text { easement }\end{array}$ & $\begin{array}{l}\text { Number of } \\
\text { easements }\end{array}$ & $\begin{array}{l}\text { Approx. hectares } \\
\text { protected }\end{array}$ \\
\hline Argentina & Fundación Neuquen & 2000 & 1 & 144 \\
\hline Costa Rica & CEDARENA & 1992 & 42 & 5,000 \\
\cline { 2 - 5 } & Others & & 15 (approx.) & 500 \\
\hline Ecuador & CEDA & 1999 & 4 & 300 \\
\hline Guatemala & FundaEco & 1999 & 4 & 7,233 \\
\hline Mexico & Pronatura & 1998 & 10 & Unavailable \\
\hline Paraguay & Natural Land Trust & 2000 & 12 & Unavailable \\
\hline
\end{tabular}

Source: ELI et al. 2003

\footnotetext{
1 "Developers Find Payoff in Preservation. Donors Reap Tax Incentive by Giving to Land Trusts, but Critics Fear Abuse of System". By Joe Stephens and David B. Ottaway. Washington Post Staff Writers. Sunday, December 21, 2003
} 


\section{d. Community accords}

"In most Latin American countries, a significant portion of private rural lands may be held in common ownership by campesino communities, which are productive communities organized under the country's agrarian laws. Depending on the flexibility of a country's laws, lands that are privately owned by communities can be subject to conservation easements, private reserves, and other land conservation instruments, just like any other private lands. In addition, community lands can be protected by quasi-legislative decisions made by community assemblies and other similar bodies that are empowered to act on behalf of the community. In general, these community agreements are made in consideration of some financial benefits to community members in compensation for conservation actions" (ELI et al. 2003).

Despite the extent of community-owned lands in Latin America, there are comparatively few instances of formal private land protection actions undertaken by communities. One of these is outlined in the Chapparri case study in the Peru, where a campesino community set aside 34,000 ha of its lands to create Peru's first private reserve. Also in Peru, the conservation group Tropical Nature has obtained the agreement of several communities to conserve their rainforest lands in exchange for providing capital and tourism expertise to help develop jointly-owned ecotourism projects on community lands (SPDA 2003). These examples indicate the potential of working with communities, but also that some organizing force by an individual or NGO may be necessary to initiate and help to carry out a formal conservation program.

Mexico is a particularly important country in this regard, as communal groups (called ejidos or communities) own 52 percent of all land. Here, the conservation NGO PRONATURA A.C. has helped create conservation agreements with land-owning communities to protect the areas of Las Bufas and El Carracito in the Sierra Madre Occidental. This is a complex process, as Mexican law requires that community agreements be carried out through a number of procedures, including certification by a formally convened Assembly in the presence of a federal government official, and inscription in the National Agrarian Registry. In another case, PRONATURA A.C. acquired the timber rights over 2,500 ha of communal land for a term of 15 years, for an annual payment to the community members, in return for which community members agreed to refrain from cutting trees and taking other actions that might disturb sensitive conservation areas (PRONATURA A. C. 2003). 


\section{e. Other voluntary methods}

There are other voluntary methods to allow the conservation on private ownership that have been developed and applied in order to achieve certain conservation goals. Some of the more often mentioned are:

- Conservation concessions on public lands. Conservation concessions are lease agreements in which governments lease public lands or resources to conservation groups to be managed for conservation purposes. Attempts to apply this tool were undertaken in Chile without success (CODEFF 2003). A second type of use of concessions for conservation purposes occurred when conservation NGOs outbid resource users for the rights to traditional extractive concessions over public lands. In a number of countries Conservation International (CI) has purchased the rights to existing timber concessions from logging companies and then nullified them (Rice et al. 1997 and 2001, Rice 2003).

- Donation or transfer of lands to a public park system. This is another strategy for private lands conservation, primarily used by NGOs. A private entity purchases land and then donates it to the government for inclusion in the public park system. Donation to the public park system assures long-term conservation of the land and allows the government to assume the costs of management. For instance, this was applied in Argentina (Castelli 2001).

- Usufruct: the usufruct is a personal, contractual civil law right over land through which a property owner grants to another the use and enjoyment of the property. This tool was applied in Mexico and Colombia (PRONATURA A.C. 2003, RESNATUR online 2004).

- Comodato: a civil law contract through which a landowner lends land, or rights to resources on the land, to another person free of charge. It was applied in Mexico (PRONATURA A.C. 2003).

- Conditional donations and legacies and lease agreements.

- Temporary use of property in exchange for the payment of rent. This tool was applied in Ecuador (see Alianza Jatun Sacha 2004 and CEDA 2003). 


\subsubsection{Compulsory restriction on the use of private land}

In Latin America, involuntary conservation restrictions created by direct government regulation has been the most widely used legal approach for achieving the conservation of private lands. This approach takes a number of forms under the forestry and protected area laws: general restrictions placed on all landowners to protect soils and watersheds; general restrictions regulating tree-cutting; and special restrictions on private lands that lie within designated resource conservation areas (ELI et al. 2003).

\section{a. Restrictions related to soil conservation and erosion control}

Countries like Argentina, Brazil, Chile, Costa Rica, Ecuador and Peru impose a number of environmentally beneficial limitations on land uses, principally to assure sound land use planning and erosion control. One set of laws requires either the strict or partial conservation of natural vegetation along water courses, in watersheds and on steep slopes. In addition, most countries also require a management plan and permit for the cutting of any tree on larger rural properties, potentially allowing the state great control over forest exploitation or development practices (see table 4) (Castelli 2001, Fundación O Boticario 2003, CODEFF 2003, CEDARENA 2003, CEDA 2003, SPDA 2003).

These general restrictions against deforestation along watercourses, in watersheds, and on steep slopes, however, are rarely enforced in any country. The requirement for a management plan before the cutting of timber is typically enforced only against large landowners and commercial timber operations, leaving many deforestation activities unaffected. Government capacity to review and monitor forestry management plans is also weak in most countries. Although these laws could provide the framework for one of the strongest approaches for private conservation, their potential remains untapped because of this widespread lack of enforcement (ELI et al. 2003). 
Table 4: Some examples of land use restrictions for environmental purposes

\begin{tabular}{|l|l|l|l|l|}
\hline & \multicolumn{1}{|c|}{$\begin{array}{c}\text { Protection of } \\
\text { watercourses } \\
(\mathrm{m})\end{array}$} & \multicolumn{1}{|c|}{ Watersheds } & \multicolumn{1}{|c|}{ Steep slopes } & \multicolumn{1}{|c|}{$\begin{array}{c}\text { Forestry plan } \\
\text { required }\end{array}$} \\
\hline Argentina & 100 & yes & $>20$ degrees & \\
\hline Brazil & $30-500$ & yes & $>45$ degrees & \\
\hline Chile & $100-200$ & limited & $\begin{array}{l}>45 \text { degrees } \\
\text { variable }\end{array}$ & $\begin{array}{l}(>20- \\
1,000 \text { ha })\end{array}$ \\
\hline Costa Rica & $10-50$ & limited & n/a & properties $>2$ ha \\
\hline Ecuador & 50 & some areas & n/a & all properties \\
\hline Peru & 50 & yes & n/a & all properties \\
\hline
\end{tabular}

Source: Adapted from ELI et al. 2003 and Castelli 2001, Fundación O Boticario 2003, CODEFF 2003, CEDARENA 2003, CEDA 2003, SPDA 2003

\section{$\underline{\text { b. Conservation restrictions }}$}

Some countries, most notably Brazil, have even stronger laws that impose mandatory conservation practices on landowners. Brazil requires all rural private landowners to preserve 20 to 80 percent of their property in natural conditions, and in some areas, such as the Atlantic Forest, totally prohibits the cutting of trees on any part of the property. These provisions in Brazil very likely represent the strongest private lands conservation tools in the Americas. Enforcement of these laws, however, is sporadic at best, and as a result these laws may have slowed, but not halted, deforestation in many critically endangered ecosystems (Fundación O Boticario 2003).

Conservation International conducted one of the few studies that has examined the root causes of the failure to enforce environmental laws, in a study regarding illegal deforestation in Brazil's southern Bahia's Atlantic forest (Sundari et al. 2002). The study found that despite efforts by the government, enforcement of environmental laws was weak because the probability of detection is generally low, and a number of other serious problems could lead to the failure to impose sanctions on violators. The study concludes that weaknesses exist in virtually every step of the enforcement system, and that improvements were needed in a number of key areas, including more adequate budgets, clarification of jurisdictional issues, greatly simplified procedures, and improved training and capacity of key personnel. 


\section{c. Mixed public-private protected areas}

Another significant form of conservation restriction on private lands in Latin America occurs when governments establish protected areas that include and regulate private lands without expropriating them. In "mixed" protected areas, the private lands are intended to stay private, but must comply with conservation restrictions (ELI et al. 2003).

Typically, these mixed public-private protected areas cover relatively large natural areas of special importance for the conservation of biodiversity or natural resources (see table 5). Although they consist mostly of private lands, many surround one or more publicly owned core areas such as national parks. Typically, the government allows farming and grazing to continue on private lands, but restricts other private land uses that could degrade the area's natural resources, such as the cutting of trees, industrial uses, and contamination of soils (ELI et al. 2003).

Table 5: Extent of mixed public-private protected areas private lands

\begin{tabular}{|c|c|c|c|c|}
\hline \multirow[t]{2}{*}{ Country } & \multicolumn{3}{|c|}{ Compulsory public-private protected areas } & \multirow{2}{*}{$\begin{array}{l}\text { Area protected by } \\
\text { voluntary means } \\
\text { (ha) }\end{array}$} \\
\hline & Designation & Area (ha) & \begin{tabular}{|l|}
$(\%$ of \\
country $)$
\end{tabular} & \\
\hline Brazil & $\begin{array}{l}\text { Area of Environmental } \\
\text { Protection, etc }\end{array}$ & $11,577,757$ & 1.4 & 405,114 \\
\hline Costa Rica & $\begin{array}{l}\text { Zona Reservada, } \\
\text { Reserva Forestal, etc. }\end{array}$ & 563,686 & 11 & 200,000 \\
\hline Ecuador & $\begin{array}{l}\text { Bosque Protector } \\
\text { (state-designated) }\end{array}$ & 2,237183 & 9 & 113,683 \\
\hline Paraguay & $\begin{array}{l}\text { Potential Areas for } \\
\text { Protected Area System }\end{array}$ & $2,662,000$ & 6 & 200,952 \\
\hline
\end{tabular}

Source: ELI et al. 2003 and Fundación O Boticario 2003, CEDARENA 2003, CEDA 2003.

The extent of land covered by these public-private areas can be considerable in some nations-11 million ha in Brazil, and as much as 6 to 11 percent of the country in smaller nations such as Costa Rica, Ecuador, and Paraguay (CEDARENA 2003, CEDA 2003, Fundación Bertoni 2002). In Mexico, this paradigm applies in the case of virtually all public protected areas because the government owns only 30 percent of the land in public protected areas and has only limited intentions to purchase the remaining land. In these countries, the amount of private land subject to conservation restrictions in these "mixed" public-private areas exceeds the amount protected by the voluntary use of land conservation tools by far (see table 5) (PRONATURA A. C. 2003). 
Actual implementation of the restrictions imposed on private lands within such "mixed" areas varies from country to country. Although they are better enforced than the general restrictions on private lands mentioned above, the restrictions are not strongly enforced, allowing gradual degradation of the area.

One of the positive aspects of a public-private partnership for these "mixed" areas would be for governments to give priority in providing incentives and assistance to private lands within important areas. The government designation defines these areas to be particularly important for the conservation of natural resources and biological diversity, and also imposes conservation restrictions on all private lands within them. Therefore, these areas are particularly suitable for public-private collaboration, and the private sector can contribute significantly to their conservation both to increase the effectiveness of state enforcement, and to work with landowners to implement additional private land conservation measures on properties (ELI et al. 2003).

However, Wunder (2004), according to studies in buffer zones of protected areas, have drawn attention to the negative effects of development projects in these areas; he recommends not to implement projects there because these appear to increase the destruction instead of protecting natural resources.

\subsubsection{Incentives: the key to private land conservation}

The majority of related studies mention that incentives are the key to develop private land conservation in Latin America (Landholz et al. 2000, Mejias et al. 2000, PROMETA 2001 and 2002, Choquehuanca 2001, Choquehuanca \& Eguino 2003, ELI et at. 2003). A good example of the impact of incentives on private conservation has been seen in the USA, where the use of conservation easements had been around for decades but only gained prominence after 1976, when the US Congress made them tax-deductible. Today, easements are held by a host of government agencies, national environmental groups, about 1,260 local land trusts and non-profit corporations devoted to conservation.

To date the governments have been the major incentives' supplier. According to ELI et al. (2003) they "are able to offer two major kinds of incentives - financial incentives such as tax exemptions and juridical incentives that increase the security of land tenure (that is, protecting the land against challenges by parties ranging from squatters to the government)".

Conservationist NGOs are another main incentives' provider, but they have normally worked to develop favourable policies and to get state's incentives (CEDARENA 2000). Recently, 
private enterprises have begun to take part in private conservation through the financing of some initiatives, but there still exist very few cases.

The use of economic incentives coming from the governments has been very limited in Latin America. A few countries have provided tax incentives (e.g. Brazil, Guatemala, Bolivia and Ecuador), but only Costa Rica has provided a significant financial incentive for landowners through the payment for environmental services (PES). However, given the substantial pressures on the budgets of most Latin American countries, the future of economic and tax incentives to promote private lands conservation is not promising. On the other hand, rural property taxes in Latin America are traditionally very low and the tax collection systems are weak, therefore this form of incentive has not been very attractive to private landowners (ELI et al. 2003).

The best-known example of incentives for nature conservation on private land is the payment for environmental services in Costa Rica (through the forest conservation). Nevertheless, it has had problems to include all social rural sectors. A study to evaluate the impact of the compensation incentives stressed the unfair benefits' distribution of the PES program because the socio-economic profile of those who have access to PES does not include persons living below the poverty line (Ortiz et al. 2003). Regarding this fact, Camacho \& Reyes (2002) explain that "besides the lack of information, exclusionary factors have to do with complicated, bureaucratic procedures for accessing PES and the high transaction costs; along with the fact that the scheme only recognizes private landowners with title, not landholders or usufructuaries. Thus, the requirements related to property titles, the forestry orientation and the technical requirements, have mainly favored large and medium size private landowners". As can be seen in this case, economics incentives are not always the best options due the complex social and land situation in Latin America, which could avoid the landowners' access to incentives (Mejias et al. 2000).

Increasing the juridical security of land through designation of the property as a private protected area was found to be a major governmental incentive in many countries, especially in those with relatively weak judicial systems (Mejias et al. 2000, Piskulich 2000, ELI et al. 2003). However, according to ELI et al. (2003), in relatively few instances the private conservation status led to greater juridical security for land.

Mejias et al. (2000) and Piskulich (2000) agree with the statement that there is no ideal incentive to promote private land conservation; therefore the main strategy should be a permanent innovation of incentives adapted to the socio-economic context of each country. 


\subsection{Private conservation in Bolivia: Methods and results of the first efforts}

According to the Political Constitution of the State, the natural resources are a heritage of the Bolivian State and, as such, their protection and rational use is a right and obligation of the society in general. Bolivian legislation allows, through distinct legal tools, the voluntary and compulsory establishment of conservation areas on private lands.

\subsubsection{Voluntary methods}

\section{a. Private protected areas by governmental resolutions}

"The first initiatives of private land conservation in Bolivia arose in the 1970s, when some private owners in the eastern region declared their properties by means of Supreme Decrees and Ministerial Resolutions. In 1975, the Huancaroma Ranch was created as Wildlife Refuge followed by San Rafael, Espíritu, and Yacuma ranches in 1978, the ranches El Porvenir, Esmeralda, El Salvador, and El Cayman were created in 1988 as Wild Fauna Refuges. However, these attempts were unable to fulfil their conservation objectives due to the difficulties of the legal and institutional framework in which they were established, and because they were isolated initiatives created at a time when the instruments for conservation and management of natural resources, biodiversity, and protected areas, were not yet clearly defined. Nevertheless, some of the owners of these initial areas - in spite of the failure in the first attempt - are still willing to retake the initiative as long as an adequate legal framework and economic and technical incentives exist" (PROMETA 2003).

\section{b. Natural Heritage Private Reserves}

Since 1996 the so-called new Forestry Law provides a legal basis to establish Natural Heritage Private Reserves ${ }^{2}$ (NHPRs). These reserves are defined as: "voluntary ecological/conservation easements established by the landowner to preserve the biological values and scenic beauties in his property" (Artic. 13 of Forestry Law); they can be established/declared in a part or in the total of the ownership. The area destined for a NHPR is voluntarily determined using a land-use plan and the owner has to define the management activities that should be conducted in the area through a management plan (Regulation of the Forestry Law).

\footnotetext{
${ }^{2}$ The NHPR are called in Spanish "Reservas Privadas del Patrimonio Natural" (RPPN).
} 
The NHPRs can be created for a minimum period of 10 years and over a maximum area of 5,000 ha. The economic incentive for those who create NHPRs lies in an exemption from payment of property taxes. Legal advantages are the fact that the possession and dominion of a NHPR by the owner are inviolable by a third part and irreversible for cause of abandonment. In addition, the NHPR status allows an owner to fulfil the need to justify the socio-economic function of his property, this function is a requisite to own land in Bolivian rural areas (INRA-Law or law of the Land). The establishment of a NHPR formalizes the voluntary decision to set aside land for conservation and therefore justifies the corresponding land use. In this way an alternative use option was created against the historical tradition of having to deforest land to ensure tenure. The landowners must have valid property titles to establish a NHPR, this requirement is a mechanism to avoid the use of this tool for land trafficking.

Until September 2002, the Forestry Superintendence (SIF 2003) registered 33,144.51 ha of land set aside for conservation in legally established private properties $(0.03 \%$ of the Bolivian territory). Most of the NHPRs are found in the department of Santa Cruz, in the province of Ñuflo de Chávez (see annex 2). This information shows that the area protected in NHPRs is still very small in comparison with the areas under State protection, in addition most NHPRs are disperse and distant from State protected areas, as can be seen in figure 1. However the majority of NHPRs are saving habitats not yet protected and they will be important to start major conservation initiatives as the establishment of large corridors.

Nevertheless, this tool nowadays constitutes the principal option for private conservation in Bolivia and will do so in the future because NHPRs have a great advantage compared to other mechanisms because "their legal regulation cycle is already complete, a national Law is in existence as well as the corresponding regulations and technical norms to allow its implementation" (Saucedo 1999).

One of the most important disadvantages of NHPRs is that they have been created with the purpose of especially preserving forest areas; therefore there are difficulties in protecting other kinds of ecosystems through this method. In addition, according to PROMETA (2003), NHPRs cannot encompass an area greater than 5,000 ha, and cannot be created for less than a 10-year term (the law does not establish a maximum term of duration). Besides, the tax exemption is not a very attractive incentive because of their low costs and the tradition of tax evasion. 


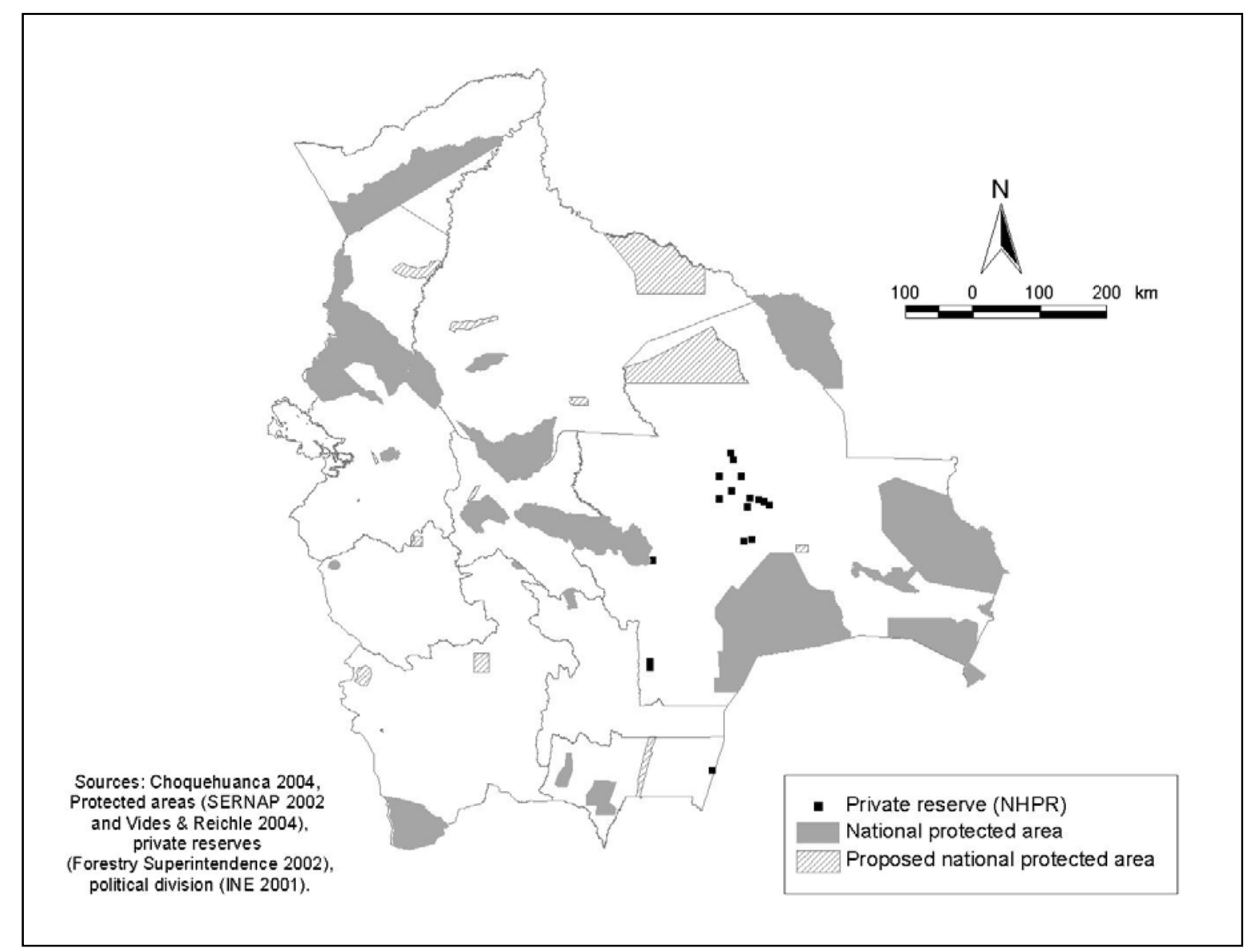

Figure 1: Location of Natural Heritage Private Reserves and national protected areas

In the recent results of an explorative project to develop methods and tools for conservation on private land, which was carried out by the Bolivian NGO FAN in the buffer zone of Amboró National Park (tropical Andes), it is mentioned that one of the most important obstacles for the establishment of private reserves (NHPR) is the confusing land property situation (Choquehuanca \& Eguino 2003). In this region less than about 5\% of the landowners have official land titles and most boundaries between properties are not well-known, which complicates the possibility to establish private reserves. In addition, this study shows a very strong social demand for land by settlers, who consider protected areas as a mechanism to exclude poor people from the access to the use of land. The attempt to establish private reserves in this region also allowed to identify a very bureaucratic process to fulfil all requirements for the conservation on private land; thereby not only socio-economic difficulties but also institutional state procedures are stopping the spreading of NHPRs (Choquehuanca \& Eguino 2003). 


\section{c. Private reserves under the General Regulation of Protected Areas}

In the General Regulations of Protected Areas of the Environmental Law -among other categories- Private Protected Areas (Áreas Protegidas Privadas, APP) are mentioned, which "... are those managed and financed voluntarily by individuals that without being part of the National Service of Protected Areas, will develop their activities within the framework of the national system of protected areas". However, to date there exists no application regulation to oversee the creation of these areas, and for this reason they have not yet been created (Choquehuanca 2003, PROMETA 2003). In the past years, PROMETA has promoted the discussion of a regulation proposal, but up to now this promising initiative has found very little support among policy makers.

Nowadays, a proposal of a law concerning protected areas is discussed among the government and the civil society. One of the most controversial and polemic topics is the one on Private Protected Areas. Indigenous' and small-scale farmers' representatives have opposed to this measure based on the concern of a possible misuse.

\section{d. Conservation easements based on civil law}

In Bolivia appurtenant easements of the Civil Code can be used to allow the protection of biodiversity on private lands. The civil Code determines that "By virtue of the easement the owner of the rural property can, for utility or benefit, make use of someone else's rural property or prevent the owner of the latter the exercise some of its faculties." (Bolivian Civil Code article 255)

In 2003, the first conservation easement was established in the Department of Santa Cruz (see Box 2) by two landowners supported by the NGO FAN-Bolivia (Choquehuanca \& Eguino 2003). In this process, some advantages and challenges of the use of easements were identified. As advantages can be mentioned: first, the duration of the whole procedure to inscribe the easement was significantly faster than any of the other methods; second, the contract, which enforced the compromise for conservation, was done according to the landowners' possibilities and wishes; third, the owners' decision was not conditioned by limits of time or surface. In spite of the successful inscription of these easements, some doubts and challenges to spread this voluntary tool still exist. First, the use of easements is very new and most of the state employers do not know the application of easements with conservation purposes, therefore a training process for employers and landowners is needed; second, due to the lack of this knowledge, the legal force to put these contracts into effect is relative, this means in the case of the transgression of contracts it is not clear if the Civil Court 
could take part in the defence of the nature conservation, and third, the limits between the easement's legal norms and other environmental and land regulations are not yet clear. For instance, it is supposed that the easements have no restrictions in time and surface, but rural ownerships are regulated by land law (INRA). In the case of the establishment of a large privte conservation area $(>5,000 \mathrm{ha})$, it seems to be probable that the land law has more application and force in comparison to the easements. Therefore, probably, the easements could be restricted to small areas, especially to suburban areas. (Choquehuanca \& Eguino 2003).

\section{e. Land purchase}

In Bolivia, two national environmental NGOs, PROMETA and FAN-Bolivia, have purchased rural lands to protect natural ecosystems. PROMETA has purchased and established three private protected areas, including the Corbalán reserve, a large area in the Chaco ecoregion (PROMETA 2003). These private reserves are located in places with low population density in the south of Bolivia.

FAN-Bolivia has purchased land in the buffer zone of the Amboró National Park, a zone with high conservation priority (Araujo \& Ibisch 2000) and threatened due to the strong process of settlements by migrant people. The main objective for this purchase was to stop the progression of the agricultural frontier in direction of the National Park. However, the carrying out of conservation work has been difficult due to conflicts with neighbours and new settlers, who want to take the land for production purposes (Choquehuanca 2001). Although FAN has the property rights of the land and there is no doubt about the need of conservation, the current situation of poverty in this region and the increase of the population forces to identify new and alternative methods to resolve these conflicts. In this context, FAN is developing a way to share the benefits and compromises of the conservation of their ownership with the local farm neighbours. In conclusion, FAN's experiences show that the land purchase in areas with high population density does not seem to be an effective method to protect biodiversity under the mentioned conditions (Choquehuanca 2001, Choquehuanca \& Eguino 2003).

FAN has also successfully contributed to the increase of the area of the Noel Kempff National Park through land purchase (to be returned to the Government) and the buying of forest concessions. The project terminated logging rights for logging concessions and private properties on 650,000 ha of government-owned land bordering the Noel Kempff National Park and lead to the inclusion of this land in the park. This doubled the size of the park, and 
hence the safe range for species requiring extensive tracks of land, such as the manned wolf and jaguar (Powers 2004)

\section{$\underline{\text { f. Conservation concessions }}$}

The Bolivian rural land law (INRA, article 26) authorizes the use of this tool for conservation purposes. The first attempt to use this legal instrument has been promoted by Conservation International (CI). Since early 2003, the "Fundación José Manuel Pando", the Chicago Field Museum and CI have been working in an area of over 100,000 hectares in north-western Bolivia to establish a reserve comprising a mosaic of traditional conservation areas on public lands interspersed with conservation agreements on private and communal holdings. Conservation agreements will take a variety of different forms, including easements, environmental service payments, conservation concessions and others. As a first step, the CI and its partners have supported the Bolivian Government in its land titling process to clarify land tenure in the area. The Reserve would protect habitat that is home to 14 species of primates representing all new world subfamilies, including the rare Goeldi's monkey, (Callimico goeldii) (Rice 2003).

The slowness of the titling "saneamiento" process under the INRA law is the main reason why this instrument has not yet been applied, the exact location of fiscal land available to be granted under concession is currently unknown in most of the nation (PROMETA 2003).

\section{g. No formal accords to voluntary protection on private land}

One of the first studies regarding private land conservation in Bolivia indicates that local ways to preserve natural values have been already undertaken in rural areas. These experiences are not law-based but social-accords-based (Choquehuanca 2001). This study describes local mechanisms for the surrounding area of the Amboró National Park, which are grouped in the following categories: (a) communities of subsistence farmers who protect areas which are a vital source of water for irrigation (e.g. Cabracancha community); (b) communities that conserve primary forest as a scenic resource used for ecotourism (Yunga community); and (c) landowning conservationists who protect the resources of their properties. These local initiatives cover a total surface of 4,129 ha $(0.7 \%$ of the study area $)$ and directly contribute to lowering the pressure exerted on the intact areas of the Amboró National Park (Choquehuanca 2001, Choquehuanca \& Eguino 2003).

There are other examples of private land conservation across the country, for instance the reserve "Paraiso del Cuervo" (Tarija, southern Bolivia), a small family enterprise, which 
combines the family's capability and inversion with indigenous initiatives of ethno-tourism through a private cooperation deal.

The majority of these options to protect the natural values have as a common feature the combination of a conservation initiative with a certain use of natural resources or environmental services, for instance the protection of water sources for irrigation purposes or the protection of pristine landscapes for ecotourism, etc. Hence, the use of resources is one of the key conditions to achieve sustainable initiatives in the long term.

\subsubsection{Compulsory restriction to protect private lands}

\section{a. Ecological easements or compulsory protected areas}

Ecological easements are mandatory restrictions that protect fragile soils within rural ownerships according to regulations of the Forestry Law. The easements are located in areas prone to degradation such as soils of eolic origin, on steep slopes, riverbanks, and wetlands. In addition, windbreak curtains that have to be established on agricultural land are considered as ecological easements.

The definitions of shape and distance of these areas is undertaken by the land-use planning or "Predial Ordering Plan" (POP). Medium and large rural holdings as well as properties located in forestry areas have to undertake the land planning.

Although the protection's definition of "ecological easements" was done on the basis of soil criteria, they can contribute to the protection of biodiversity because these fragile areas normally coincide with vital places for wild species (for instance riverbanks are important sources of water for mammals). Furthermore the ecological easements are constituted in perpetuity, imposing conditions of strict and specific protection.

According to PROMETA (2003), by the end of 2003, 87,278 ha exist under protection through this regulation within private properties that have authorization of the Forestry Superintendence to undertake forestry developments.

The ecological easements are very important instruments for the State to demand the protection of fragile or important areas for biodiversity that are located on private property, and granting as an incentive a tax exemption to owners who make use of it. However, the enforcement of these areas has been avoided due to lack of monitoring and education programs (Choquehuanca \& Eguino 2003). 


\section{b. Land use restriction in "Natural Area of Integrate Management"}

A Natural Area of Integrated Management (NAIM) is a category of national protected area that establishes restriction of natural resources use, but, at the same time, it allows the development of production activities according to management plans. NAIMs were created in areas in which human populations have been already living or in places recently settled. In the majority of cases, the population have maintained open conflicts with the protected areas' administration offices because of the restrictions of use (Pacheco 2001, Choquehuanca 2001).

The incorporation of indigenous groups and local populations in the management of protected areas has become effective upon the creation of Steering Committees, which are the organizational tool for ensuring a direct participation of the local population in the process (Rivera 2004), but in some cases these councils were openly opposed against the area administration (Pacheco 2001). 


\section{GENERAL ASPECTS OF THE STUDY AREA: THE TRANSITIONAL REGION CHIQUITANO-AMAZON TR-CHA}

\subsection{The physical environment}

\section{a. Location}

The study area is located in the lowlands of Bolivia $\left(60^{\circ}\right.$ to $61^{\circ} 33^{\prime}$ of western longitude and $14^{\circ} 40^{\prime}$ to $16^{\circ} 40^{\prime}$ southern latitude). Politically the area belongs to the Municipality of San Ignacio de Velasco in the Department of Santa Cruz.

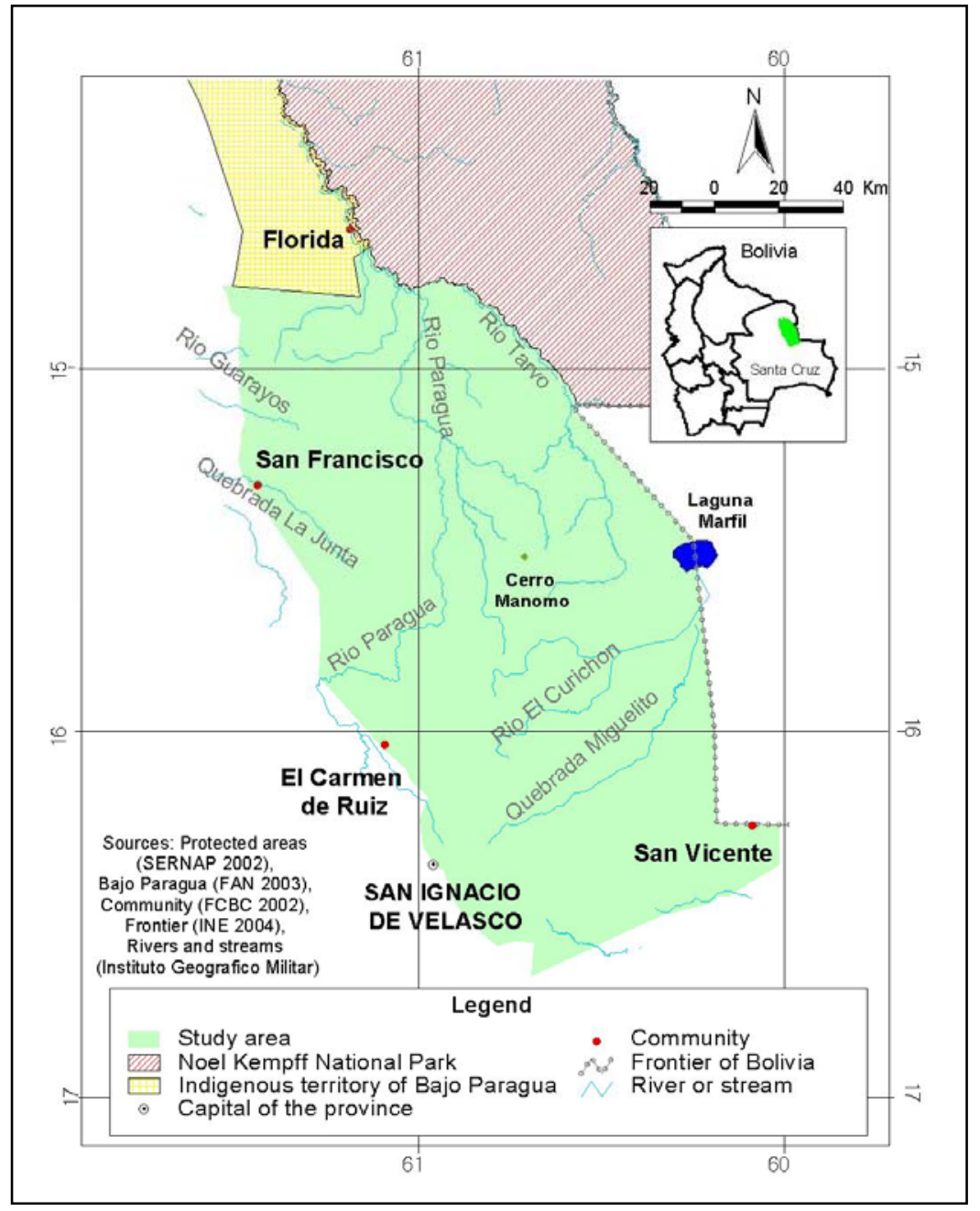

Figure 2: Map of the study area 
Figure 2 shows the physical boundaries of the study area, as there are: in the north, the southern border of the Noel Kempff Mercado National Park and the Forest Reserve of Bajo Paragua; in the south, the southern political boundary of the San Ignacio-Municipality; in the east, the international frontier between Bolivia and Brazil and, finally, in the west, the roads between San Ignacio and Santa Rosa and between Santa Rosa de la Roca and Florida. This area has been called "Transitional Region Chiquitano-Amazon" (TR-CHA) in this study because it joins the deciduous and semi-deciduous forest with the Amazon forest.

\section{b. Climate}

According to Köppen's empiric classification, the area corresponds to the tropical climate with seasonal summer rains, zone Aw (Bradshaw \& Weaver 1993).

However, this classification takes only two factors (temperature and precipitation) into consideration and thus explains the climate of this area only partially. A classification after Brads \& Weaver (1993), based on causal factors, describes the climatic conditions much better. It indicates that areas placed between arid-dry and wet equatorial regions, as the transitional region Chiquitano-Amazon, experience an alteration of dry, low-sun seasons and wet, high-sun seasons. These areas are labelled as "tropical seasonal climatic environments" and also occur in Venezuela, the interior eastern Brazil and Paraguay.

Already based on the few data available for the TR-CHA it becomes obvious that the study area has a transitional climate as Brads and Weaver described. Rainfall increases from south to north, from $1000 \mathrm{~mm}$ to $1500 \mathrm{~mm}$ (see figure 3). The distribution of precipitation is monomodal, a maximum of precipitation occurs between January and February and minima in the period of June till August, as can be seen in the climatic diagram of San Ignacio (figure 4).

With regard to temperature, the average varies from $24.5^{\circ} \mathrm{C}$ in the southwest to $25.5^{\circ} \mathrm{C}$ in the northeast (Fig 3). Maximum and minimum temperatures have the same temporal behaviour as the rainfall (see Fig 4) (Villarpando et al. 2002) 


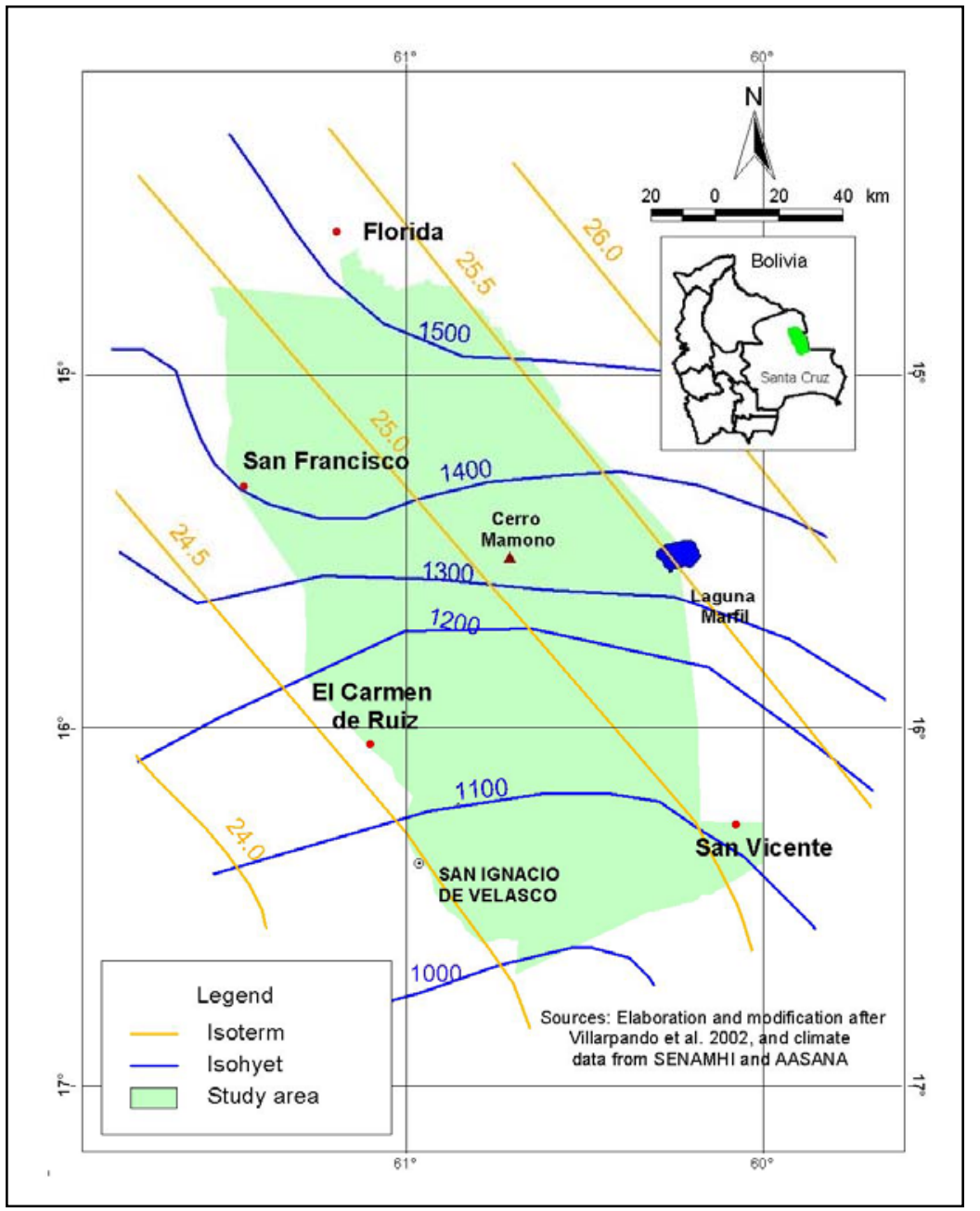

Figure 3: Map of isohyets and isotherms of study area

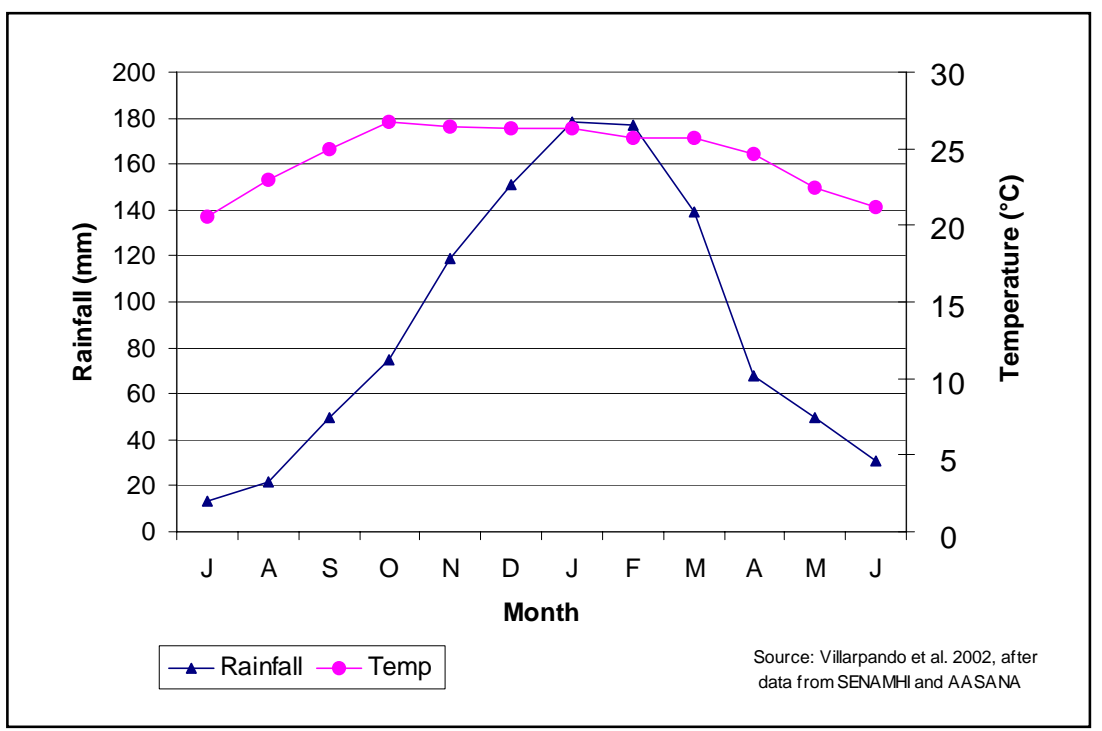

Figure 4: Climate diagram for San Ignacio de Velasco 


\section{c. Physical geography and topography}

The area of study "Transitional Region Chiquitano-Amazon" is part of a valley placed among the Chiquitano, Matto Groso and Caparuch mountain ranges (see figure 5). The relief is composed by western soft hillsides of the Chiquitano mountains ranges and flood plains of the rivers Paragua, Tarvo and their tributaries. These rivers form braided-streams with relatively shallow and wide channels, which are common of tropical seasonal humid regions due to the combined effect of seasonal rainfall and the chemical weathering that produce fine clay soils. As a consequence, these streams lower the surface across the whole landscape, rather than creating valleys by deep stream incisions (Bradshaw \&Weaver 1993).

The topography of the zone presents a west-east variation from the hillsides of the Chiquitano mountain ranges, with gentle slopes, to the flat land near Paragua and Tarvo River, below 220 m, where annual floods occur. Here the Manomo Hill (cerro Manomo) approximate in the centre is the only higher elevation that disturbs this topographic pattern. The altitude changes in direction north and east and varies between on average $400 \mathrm{~m}$ in the town of San Ignacio to $174 \mathrm{~m}$ in the Community Florida and $190 \mathrm{~m}$ in the surroundings of the Marfil lagoon. The mentioned Manomo Hill is the highest elevation with $684 \mathrm{~m}$.

\section{d. Geology and soils}

The Chiquitano Mountain ranges and the Brazilian Shield determine the geological characteristics of the area. The Chiquitano Mountains are made up of Precambrian rocks, the oldest rock formation on Bolivian territory. The Brazilian Shield is characterised by flat shapes forming very shallow soils and very old rock outcrops such as granite and basalt (Rafiqpoor \& Ibisch, 2004).

The soils of the region are generally classed as having no or only a shallow top horizon and a nutrient-poor subsoil with a high clay content, except for a few sectors with forest coverage, which are rich in organic matter. From the point of view of soil use, the region is characterized by soil classes that put severe limitations on farming. The majority of the soils are classified as Class VI (appropriate for mixed farming cattle-crops, or permanent crops, with erosion and/or fertility limitations) and VII (appropriate for mixed farming or permanent crops, with severe limitations caused by drainage, erosion and/or fertility) (Wachholtz 2002). 


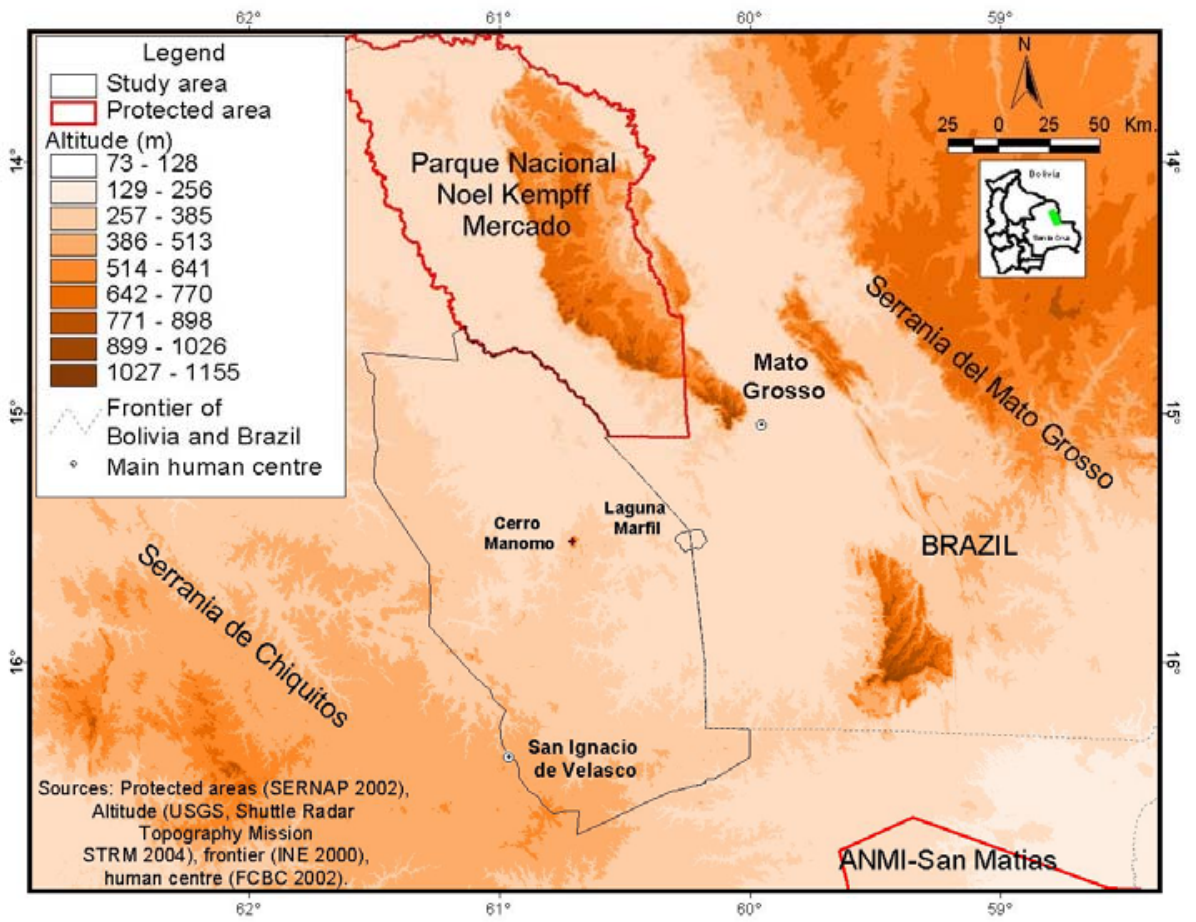

Figure 5: Landscape characteristics of the study area.

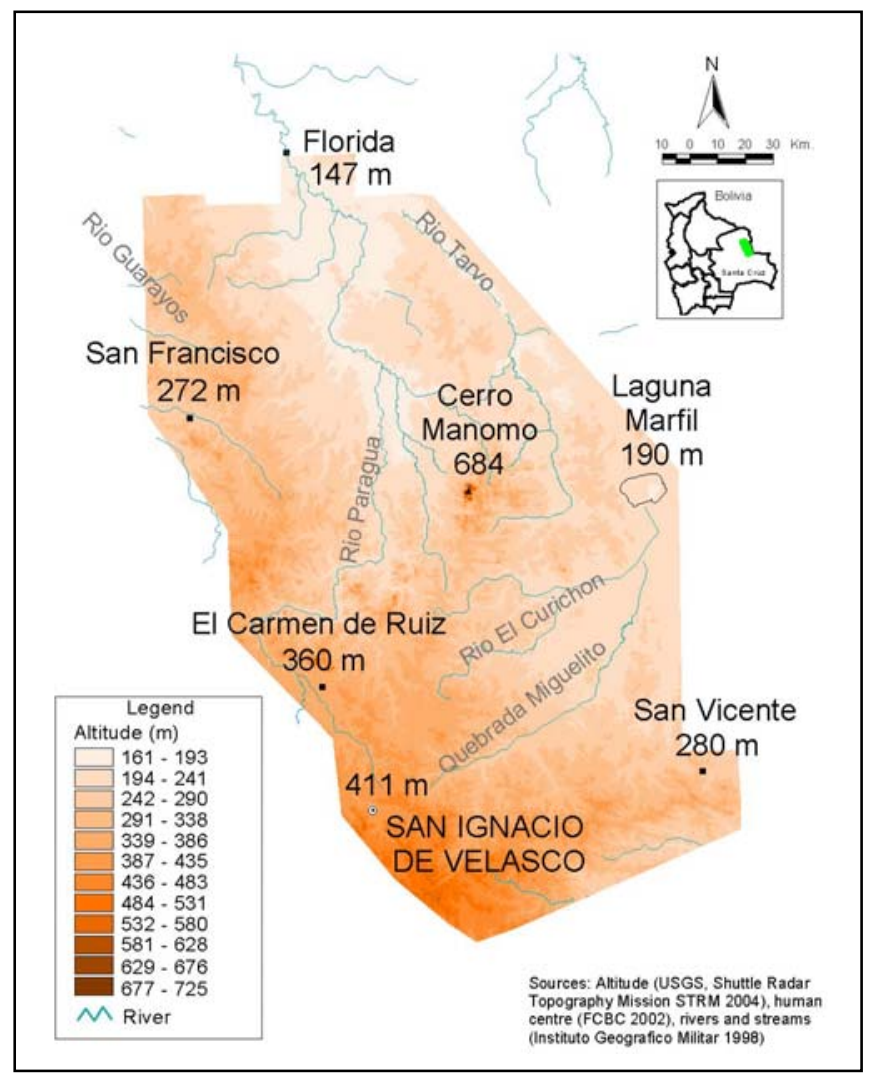

Figure 6: Diagram of altitude and hydrography of the study area 
From the point of view of the potential of the soils for forest management, taking into account forest species diversity, forest development, forest conservation and ecological conditions (soil type, climate, water regime and topography), the region shows a regular to high potential for forestry. Comparing soil suitability for agriculture with forestry and mixed farming, there is a clear indication of suitability for the latter. Mixed farming is, along with logging, the activity with greatest importance in the zone of action. The majority of the flooded savannas, which cover an important portion of the area, are used for mixed farming (Prefectura del Departamento de Santa Cruz, 1996; Ibisch et al. 2002; FCBC online 2004).

\section{e. Watersheds and streams}

The majority of the study area (90\%) belongs to the Amazon basin draining to the north into the Amazon River; the rest, specifically the areas located in the south, drain to the Plata basin in the south. Four sub-watersheds can be differentiated in the Amazon basin: Tarbo, Paragua, Curichon and Guarayos. The first three watersheds have a greater influence in the study area than the Guarayos basin, which drains to the west. The lagoon Marfil, with a surface of around $130 \mathrm{~km}^{2}$ is the largest water body in the area (see figure 6).

Seasonal flooding affects large parts of the study area and has a mayor influence on soil characteristics and vegetation. As a consequence, apart from the climate, both the soils and the flooding regime determine the most important factor geo-diversity which in the literature always shows a high correlation with the pattern of biodiversity (Rafiqpoor \& Ibisch, 2004).

The function and importance of the hydro-regulation for this area should be underlined here, because the TR-CHA is the headwater of the large river "Itenez" (Guapore), which plays a similar regulation role in the study area as does the Pantanal to the hydro-system of the Paraguay River.

\subsection{Biological and ecological aspects}

\section{a. Ecoregions}

The use of ecoregions to classify natural areas, according to Ibisch et al. (2004a), is effective for conservation activities because it takes into consideration not only bio-geographical or ecological criteria but also ecological processes and interrelations.

These authors define an ecoregion as an area that consists of a characteristic grouping of natural communities that: (1) share many taxa, ecological dynamics and environmental 
conditions; (2) have greater biological and ecological interrelations and interdependences among themselves than with the communities found outside the region; (3) show common patterns for biomass production, including forestry and agriculture.

In the area of study, according to the ecoregional analysis undertaken in this study, following the above mentioned definition, four ecoregions and five sub-ecoregions can be distinguished, These are the ecoregions (1) Chiquitano forest, sub-ecoregion with the same name; (2) Southwest Amazon Forest, sub-ecoregions Beni and Santa Cruz Amazon Forest; (3) Cerrado, sub-ecoregion Cerrado of the Chiquitano Region and (4) Flooded Savannas, sub-ecoregion Pantanal Flooded Savannas. Here, an additional sub-ecoregion was introduced in this study: the zone is called "Amazon Flooded Savannas" and was identified by the analysis of the vegetation units which showed different features in comparison to the Pantanal but similarities to the flooded savannas of Amazon region (see figure 7 and table 6). The principal features of these ecoregions and sub-ecoregions are given in table 6.

The transitional environmental conditions in the TR-CHA create several intermediate zones that house a high biodiversity of species, these are not described in detail in this study but it is recommended for complementary vegetations studies

Table 6: Principal characteristics of the ecoregions and sub-ecoregions of the study area

\begin{tabular}{|l|l|l|}
\hline Ecoregion & Sub-ecoregion & Characteristics \\
\hline $\begin{array}{l}\text { Chiquitano } \\
\text { Forest }\end{array}$ & $\begin{array}{l}\text { Chiquitano } \\
\text { Forest }\end{array}$ & $\begin{array}{l}\text { Ecoregion only found in Bolivia. It is characterized by being found in an area of an } \\
\text { intermediate climate between the humid Amazon and the dry Chaco. The geology is that of } \\
\text { the Precambrian Shield (Brazilian Shield). The predominant vegetation is deciduous to } \\
\text { semi-deciduous forest, i.e. it loses all or some of its leaves during the dry season. }\end{array}$ \\
\hline $\begin{array}{l}\text { Southwest } \\
\text { Amazon } \\
\text { Forest }\end{array}$ & $\begin{array}{l}\text { Beni and Santa } \\
\text { Cruz Amazon } \\
\text { Forest }\end{array}$ & $\begin{array}{l}\text { Last southern Amazonian forest of large extension on the Precambrian shield, not as rich in } \\
\text { species and of endemics as those forests further north. Very recent humid forests, some of } \\
\text { them a few centuries old. The vegetation is evergreen, transition to semi-decidual seasonal } \\
\text { forest of the Chiquitano Forest. }\end{array}$ \\
\hline $\begin{array}{l}\text { Cerrado } \\
\text { Chiquitano } \\
\text { Ecoregion }\end{array}$ & $\begin{array}{l}\text { The Cerrado or tree-ed savanna has a "mosaic" distribution, an intermingling of dry forest } \\
\text { and Pantanal Flooded Savannas. The name comes from the common terminology "Cerrado" } \\
\text { used in Brazil, where the larger part of this ecoregion is found. The vegetation in this } \\
\text { ecoregion with a semi-humid climate is composed of a lower grassy covering and small } \\
\text { bushes, with small twisted trees scattered throughout. These trees are resistant to the fires in } \\
\text { the dry season because of their thick, rough bark. The soils of this ecoregion are generally } \\
\text { shallow, stony and infertile. }\end{array}$ \\
\hline $\begin{array}{l}\text { Flooded } \\
\text { Savannas }\end{array}$ & $\begin{array}{l}\text { Pantanal } \\
\text { Flooded } \\
\text { Savannas }\end{array}$ & $\begin{array}{l}\text { Low plain seasonally flooded mainly by water from rivers that flows into the zone. This } \\
\text { area is probably different to the larger part of the Pantanal, because the water flows in } \\
\text { northern direction and the area belongs to the Amazon basin. }\end{array}$ \\
\cline { 2 - 4 } & $\begin{array}{l}\text { Amazon Flooded } \\
\text { Savannas }\end{array}$ & $\begin{array}{l}\text { Mixed plains with recent alluvial soils, flooding mainly by overflow from the Paragua River } \\
\text { and its tributaries. Altitude less than 220 m. }\end{array}$ \\
\hline
\end{tabular}

Source: Ibisch et al. (2004a) 


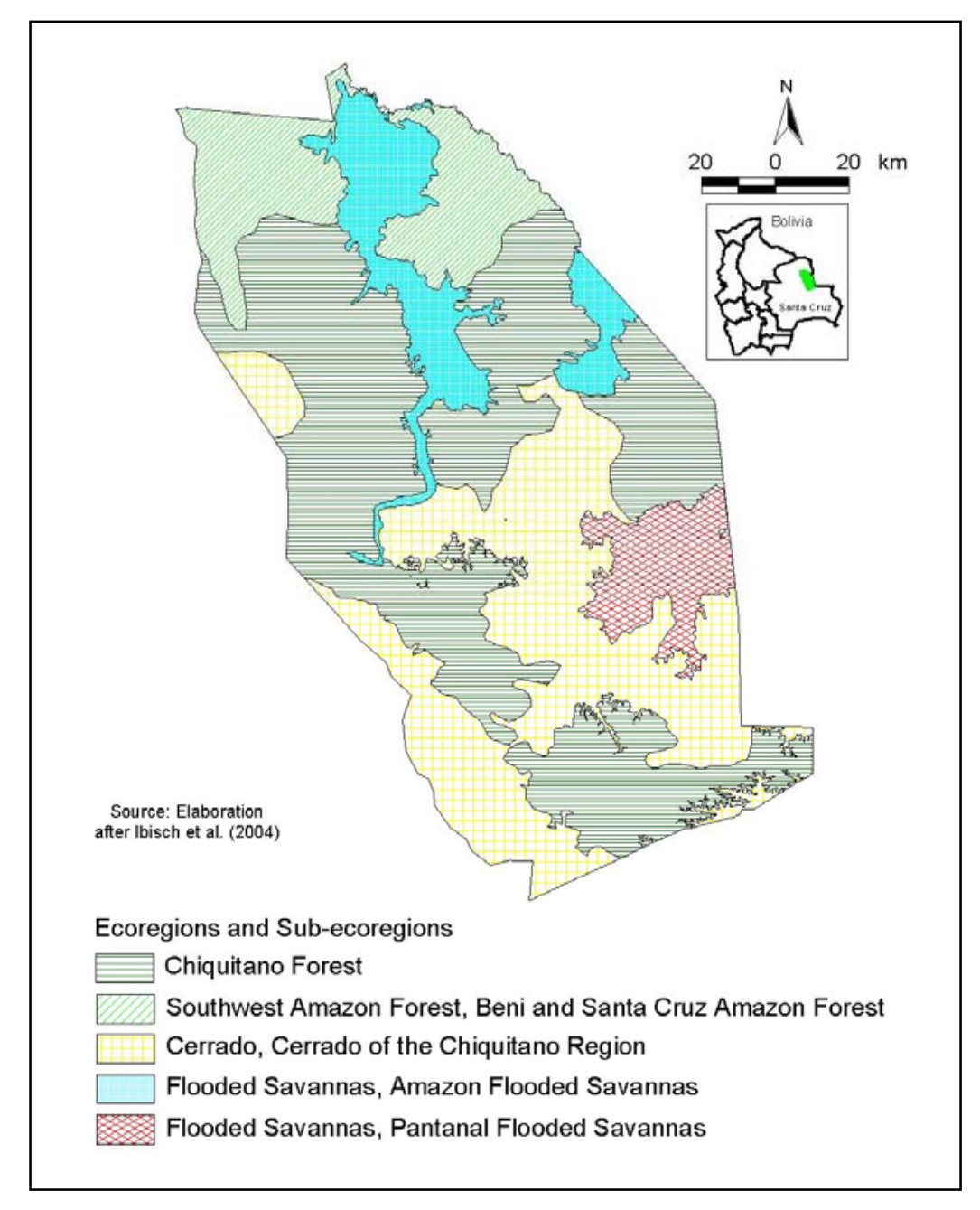

Figure 7: Ecoregions in the study area

\section{b. Flora}

Diverse vegetation units are observed in the transitional region Chiquitano-Amazon (see figure 8) that include a large number of botanical species, some of them not yet described.

A specific and detailed treatment of the botanical diversity has not been undertaken in the present study, but the information obtained from the satellite images, rapid field observations and secondary sources stress the necessity of future examinations. A description of the main vegetation units per ecoregion is given below.

\section{Ecoregion Chiquitano Forest}

The Chiquitano Forest, an exclusive bio-system of the Bolivian lowlands, covers the western part of the study zone that corresponds to the hillsides of the Chiquitano mountain range. Table 7 gives a description of vegetation units found. 
Table 7: Vegetation units of the Chiquitano forest

\begin{tabular}{|c|c|}
\hline Vegetation Units & Description \\
\hline $\begin{array}{l}\text { Lowland } \\
\text { Chiquitano Forest } \\
\text { (Chi.1) }\end{array}$ & $\begin{array}{l}\text { Forest where more than half of the trees lose their leaves in the dry season. It is found on } \\
\text { the slopes of the lowest Chiquitano mountains, on the Chiquitano Plains and on the } \\
\text { mountains in the Pantanal. Physiognomy: a dense canopy that does not allow much light to } \\
\text { penetrate. It reaches approximately } 20 \text { m in height; the emergents/emerging trees can reach } \\
30 \mathrm{~m} \text {. The principal tree species are: Calycophyllum multiflorum (verdolago), Schinopsis } \\
\text { brasiliensis (soto), Astronium urundeuva (cuchi), Anadenanthera colubrina (curupaú), } \\
\text { Caesalpinia pluviosa (momoqui) and Acosmium cardenasii (tasaá); other common species } \\
\text { are: Chorisia speciosa (toborochi), Aspidosperma cylindrocarpon (jichituriqui rojo), } \\
\text { Amburana cearensis (roble) and Machaerium scleroxylon (morado). }\end{array}$ \\
\hline $\begin{array}{l}\text { Flooded } \\
\text { Chiquitano Forest } \\
\text { (Chi. 2) }\end{array}$ & $\begin{array}{l}\text { Forest with ample distribution in the Chiquitano Plains and in flat valleys. It is established } \\
\text { on clay soils, which impede drainage and thus lead to occasional flooding. The canopy } \\
\text { allows light to pass through to the undergrowth. The main tree canopy reaches a height of } \\
20 \mathrm{~m} \text {, the emergents, } 25 \mathrm{~m} \text {. The following species are common: Phyllosthylon rhamnoides } \\
\text { (cuta), Anadenanthera colubrina (curupau), Calycophyllum multiflorum (verdolago), } \\
\text { Gallesia integrifolia (ajo ajo) and Cordia glabrata (picana). }\end{array}$ \\
\hline $\begin{array}{l}\text { Riverine } \\
\text { Chiquitano Forest } \\
\text { (not visible, } \\
\text { included in } \\
\text { flooded Chiquitano } \\
\text { Forest) }\end{array}$ & $\begin{array}{l}\text { Common in the Chiquitano Plains, especially in the valleys. It is established on relatively } \\
\text { young silty-clay soils, badly drained and occasionally flooded by rivers. Trees in the } \\
\text { canopy reach } 15 \mathrm{~m} \text {. The canopy is not continuous and allows light to penetrate to some of } \\
\text { the undergrowth. The most common trees are: Guazuma tomentosa (coco), Machaerium } \\
\text { latifolium, Phyllosthylon rhamnoides (cuta), Genipa americana (bi), Inga edulis (pacay), } \\
\text { Swartzia jorori (jorori), Gallesia integrifolia (ajo-ajo) and Acosmium cardenasii (tasaá). }\end{array}$ \\
\hline $\begin{array}{l}\text { Chiquitano } \\
\text { Mountain Forest } \\
\text { (Chi. 3) }\end{array}$ & $\begin{array}{l}\text { Forest with an equal number of trees that lose or keep their leaves in the dry season. It is } \\
\text { found in the high Chiquitano mountains, on steep to very steep slopes, on fairly deep well- } \\
\text { drained soils with organic matter on top. The canopy reaches a height of } 25 \mathrm{~m} \text {, the } \\
\text { emergents, } 35 \mathrm{~m} \text {. Among the most common species are: Astronium urundeuva (cuchi), } \\
\text { Schinopsis brasiliensis (soto), Anadenanthera colubrina (curupaú), Calycophyllum } \\
\text { multiflorum (verdolago), Caesalpinia pluviosa (momoqui), Acosmium cardenasii (tasaá); } \\
\text { other species are: Chorisia speciosa (toborochi), Aspidosperma cylindrocarpon } \\
\text { (jichituriqui rojo), Amburana cearensis (roble) and Machaerium scleroxylon (morado). }\end{array}$ \\
\hline $\begin{array}{l}\text { Canyon-bottom } \\
\text { Humid Forest (not } \\
\text { visible by satellite } \\
\text { analysis. It was } \\
\text { included in } \\
\text { Chiquitano } \\
\text { Mountain Forest) }\end{array}$ & $\begin{array}{l}\text { Forest where more than half of the trees keep their leaves in the dry season. Generally } \\
\text { found in the Chiquitano mountains at the bottom of gorges or canyons. It develops on soil } \\
\text { with high organic matter. The canopy reaches a height of } 18 \text { to } 20 \mathrm{~m} \text {, the emergents up to } \\
30 \mathrm{~m} \text {. Among the most common species are: Schinopsis brasiliensis (soto), Acosmium } \\
\text { cardenasii (tasaá), Talisia esculenta, Ocotea cernua (laurel), Nectandra megapotamica } \\
\text { (tiquirari), Lonchocarpus nudiflorens (manicillo), Cedrella fissilis (cedro), Spondias } \\
\text { mombim (zucá) and Casearia gossypiosperma (cusé). }\end{array}$ \\
\hline $\begin{array}{l}\text { Deciduos Saxicola } \\
\text { Forest } \\
\text { (Not visible, } \\
\text { included in } \\
\text { Chiquitano } \\
\text { Mountain Forest) }\end{array}$ & $\begin{array}{l}\text { Found in the Chiquitano mountains on summits with rocky outcrops. It develops on shallow } \\
\text { stony soils. The canopy is open and reaches } 8 \text { to } 10 \mathrm{~m} \text {. Among the most common species } \\
\text { are: Anadenantera colubrina (curupaú), Caesalpinia floribunda (momoqui), Chorisia } \\
\text { speciosa (toborochi), Commiphora leptophloeos (piñón), Sapium argutum (piñón blanco) } \\
\text { and Casearia gossypiosperma (cusé). }\end{array}$ \\
\hline
\end{tabular}

Source: Gillen et al. 2002; FCBC online 2004.

\section{Ecoregion Amazon Forest, sub-ecoregion Beni and Pando Amazon Forest}

Amazon vegetation covers the north portion of the area. Humid evergreen forest, liana forest, flooded forest and gallery forest are the main vegetation units. Some representative species of 
these units are Aniba guianensis, Aspidosperma rigidum, Bactris gasipaes, Caesalpinea pluviosa, Ficus spp., Hura crepitans, Inga spp., Swietenia macrophylla, etc. (Ibisch et al. 2004a).

The Amazon part of the TR-CHA is the most southern part of the Amazon Forest and has overlapping with the vegetation of the Cerrado, the Chiquitano Forest and the Pantanal. Therefore, there is no clear division between the Amazon vegetation units and the others.

\section{Cerrado, sub-ecoregion Cerrado of the Chiquitano region}

The Cerrado encompasses several units of vegetation, as can be seen in table 8 . These units are mainly located on the eastern side. The Cerrado should be underlined as the matrix that eases the transition among the other vegetation units in the study area and therefore presents a high diversity. There is no clear difference between the Cerrado and the flooded areas.

Table 8: Vegetation units of the Cerrado of the Chiquitano Region

\begin{tabular}{|l|l|}
\hline \multicolumn{1}{|c|}{ Vegetation unit } & \multicolumn{1}{c|}{ Description } \\
\hline Wooded Cerrado & $\begin{array}{l}\text { Vegetation with a wide distribution in the Chiquitano mountains, the Chiquitano Plains, } \\
\text { mountains and hills. Found on gentle to steep slopes. Trees dominate the vegetation. The } \\
\text { trees and bushes form a dense canopy at about 6-10m. The emergents are frequent and } \\
\text { reach up to 18m, these are often trees from the Chiquitano Forest. Among the most } \\
\text { representative plants are: Astronium urundeuva (cuchi), Tabebuia impetiginosa (tajibo } \\
\text { negro), Callisthene fasciculata (tinto blanco), Magonia pubescens (tutumillo), } \\
\text { Dilodendron bipinnatum (cuta pobre), Qualea multiflora (sorioco), Astronium } \\
\text { fraxinifolium (cuta de la pampa), Terminalia argentea (chisojo), Caryocar brasiliense } \\
\text { (macarurú) and Erythroxylum macrophylla. }\end{array}$ \\
\hline $\begin{array}{l}\text { Open Wooded } \\
\text { Cerrado (Ce. 2) }\end{array}$ & $\begin{array}{l}\text { Found more or less under the same conditions as the Wooded Cerrado, it represents a } \\
\text { stage of recuperation of the latter after a disturbance. Herbaceous plants dominate the } \\
\text { vegetation. The trees and shrubs form an open canopy and reach a height of 6-10m. The } \\
\text { emergents are dispersed to absent and reach 15m. The species are generally from the } \\
\text { Chiquitano Dry Forest. The species found in the Wooded Cerrado are also common in } \\
\text { this unit. }\end{array}$ \\
\hline $\begin{array}{l}\text { Wooded Savanna } \\
\text { (not visible, included } \\
\text { in Open Savanna) }\end{array}$ & $\begin{array}{l}\text { Found in the Chiquitano mountains, and the mountains and hills in the Pantanal on } \\
\text { summits and well-drained slopes on the plateaus. Physiognomy: grassland dispersed with } \\
\text { bushes and small tress reaching a height of 5m. }\end{array}$ \\
\hline $\begin{array}{l}\text { Open Savanna (Ce. } \\
\text { 3). }\end{array}$ & $\begin{array}{l}\text { Generally found in the Chiquitano mountains, and the hills and mountains in the } \\
\text { Pantanal, on summits and hills with gentle well-drained slopes on the plateaus. } \\
\text { Depending on the stage of development there are two different structures: "Campo } \\
\text { limpo", a type of pasture or open field without trees or bushes, and "Campo sujo", a } \\
\text { pasture dispersed with a few small bushes. }\end{array}$ \\
\hline
\end{tabular}

Source: Gillen et al. 2002; FCBC online 2004.

\section{Flooded Savanna, sub-ecoregion Amazon Flooded Savannas}

There is also little information available. Grasses and Cyperaceae dominate these savannas, there are also shrubs, aquatic vegetation and forest islands. 


\section{Flooded Savanna, sub-ecoregion Pantanal Flooded Savanna}

There is little botanic information available about this area. According to the satellite analysis the most visible vegetation unit is a Flooded Savanna similar to Pantanal vegetation. It is dominated by "arrocillars" (Rice-like), in hollows that can be flooded with up to 25 to $70 \mathrm{~cm}$ of water on sub-aquatic soils and by grasses like Oryza latifolia and Leersia hexandra in less deep areas.

Other observed vegetal communities are open flooded savannas, forest islands, tariquizales (that are dominated by Ipomoea carnea ssp. Fistulosa), and others. 


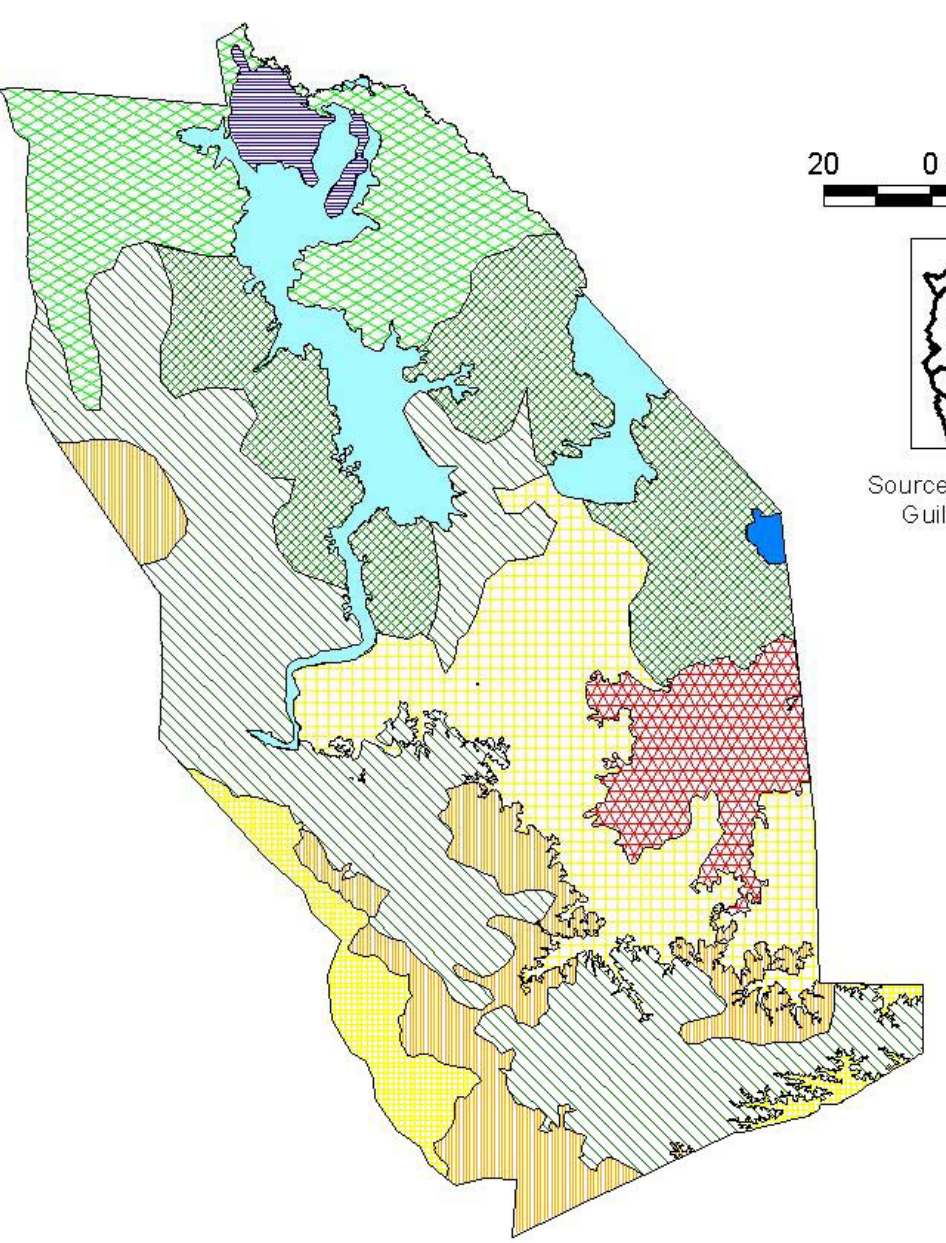

i

$20 \quad 40 \mathrm{~km}$

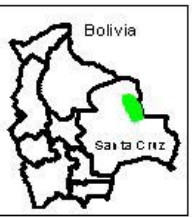

Source: Elaboration after Guillen et al. (2002)

\begin{tabular}{|c|c|c|c|c|}
\hline \multirow{2}{*}{ Ecoregion } & \multirow{2}{*}{\multicolumn{2}{|c|}{$\begin{array}{c}\text { Visible vegetation unit } \\
\text { Name }\end{array}$}} & \multicolumn{2}{|l|}{ Surface } \\
\hline & & & (ha) & $\%$ \\
\hline \multirow{2}{*}{$\begin{array}{l}\text { Chiquitano } \\
\text { Forest }\end{array}$} & $\therefore$ Chi.1 & Lowland Chiquitano Forest & $568,332.56$ & 27.80 \\
\hline & $\approx 8$ Chi.2 & Flooded Chiquitano Forest & $324,426.91$ & 15.87 \\
\hline $\begin{array}{l}\text { Southwest } \\
\text { Amazon Forest }\end{array}$ & Am.1 & Humid Evergreen Forest & $249,297.00$ & 12.19 \\
\hline \multirow{3}{*}{$\begin{array}{l}\text { Cerrado of } \\
\text { Chiquitano } \\
\text { Region }\end{array}$} & 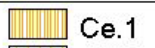 & Wooded Cerrado & $199,311.74$ & 9.75 \\
\hline & $\square$ Ce.2 & Open Wooded Cerrado & $300,293.59$ & 14.69 \\
\hline & $\square$ Ce.3 & Open Savanna of the Cerrado & $84,230.89$ & 4.12 \\
\hline \multirow{3}{*}{$\begin{array}{l}\text { Flooded } \\
\text { Savanna }\end{array}$} & $\mathrm{Pa} .1$ & Pantanal Flooded Savanna & $111,154.84$ & 5.44 \\
\hline & 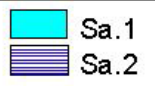 & $\begin{array}{l}\text { Amazon Flooded Savanna } \\
\text { Open Amazon Flooded Savanna }\end{array}$ & $\begin{array}{r}171,072.95 \\
31,852.74\end{array}$ & $\begin{array}{l}8.37 \\
1.55\end{array}$ \\
\hline & $\mathrm{Ag}$ & Aquatic vegetation & $4,912.30$ & 0.24 \\
\hline
\end{tabular}

Figure 8: Map of the vegetation units of the study area 


\section{c. Fauna}

In the Transitional Chiquitano-Amazon Region few studies have been carried out on animal diversity. On the contrary, good biological registers are available for areas both north and south of TR-CHA. In the north an animal biodiversity register was undertaken for the "Management Plan of Noel Kempff National Park" (FAN \& TNC, 1996), and in the south, the FCBC Foundation has promoted several assessments in the larger area of the Chiquitano forest, the Cerrado and the Bolivian Pantanal.

During the realisation of this study, biologists of the Natural History Museum of Santa Cruz, Bolivia have gathered information about the animal diversity of the area as part of a research project concerning private land conservation. These data represent one of the first records from this zone, and they were used to analyse the richness of biodiversity on private land, which is described in the next chapters. In this section a general overview of the fauna of the study area is given.

Similar to the transitional effect observed in the vegetation patterns, species from the Amazon ecoregion are dominant in the northern part of the study area. The assessments mention, for instance, mammals such Panthera onca, Felis concolor, Tapirus terrestris, Tayassu tajacu, Ateles belzebuth, Mazama americana, and rare species like Speothos venaticus, Chrysocyon brachyurus, Ozotoceros bezoarticus and Odocoileus dicotomus, among the most important. Concerning bird diversity: Aburria pipile, Ara ararauna, Aratinga leucophtalmus, Ramphastos toco, Falco parverius, Cripturellus undulatus, Jabiru mycteria, Dendrocygna autamnalis, Syrigma sibilatrix and others. The biggest registered bird is Rhea americana that is one of the most endangered species.

In the Chiquitano Forest and the Cerrado, the following mammals were registered: Callithrix argentata, Dasypus novemcinctus, Cerdocyon thous, Pseudalopex gymnocercus, Procyon cancrivorus, Mazama gouazoubira, Dasyprocta variegata, Myrmecophaga tridactyla, Nasua nasua, Panthera onca, Puma concolor, Tapirus terrestris and Tayassu pecari among the more common species. Observed birds were: Phalacrocorax brasilianus, Egretta thula, Ajaia ajaja, Jabiru mycteria, Mycteria americana, Chauna torquata, Jacana jacana y Cairina moschata. The endangered bird species Cairina moschata, Rhea americana, Ramphastos toco, Jabiru Mycteria were also found 
According to Reichle et al. (2002), comparing species diversity among vegetation types, the forests house the largest diversity of mammals and birds followed by the Cerrado and the Flooded Savannas. The opposite is true for the distribution patterns of birds and amphibians. In general, mammal diversity is very high in the whole region, due to the fact that the species in this group have a wide distribution and are not restricted to one type of vegetation. However, the diversity of birds does not have this homogenous distribution; there are vegetation types that are richer in bird species than others. For example, the highest bird diversity is found in areas where the Chiquitano Forest is intermixed with the Pantanal due to the fact that bird species common to both ecoregions can be found here. In general, the highest bird diversity can be found where there is a mixture of vegetation units, including forests and open areas with water, such as the flooded savannas. 


\section{METHODOLOGY}

This study was carried out based on the integration of two methods: the eco-regional analysis, a natural science tool, and the case study, a method used in the social sciences. A scheme of the methodology can be seen in figure 9.

\subsection{Eco-regional analysis}

According to Ibisch et al. (2000, 2002 and 2002a), the eco-regional analysis consists of the integral examination of ecological and socio-economic features of a region through geographical information systems in order to assess the current conditions, potentials and scenarios of biodiversity conservation.

The method of the eco-regional analysis was especially designed for places under circumstances where little data is available. This method has already been used effectively in some studies carried out in Bolivia (Ibisch et al. 2000 and 2002, Araujo et al. 2000, Sommer et al. 2003).

The study "Plan for the Conservation and Sustainable Development of the Chiquitano Dry Forest, Pantanal and Bolivian Cerrado" (Ibisch et al. 2002) applied this method and adapted them for environmental conditions that are dominant in the study area. For this reason, the mentioned study was the main methodological reference.

The eco-regional analysis was selected because only a few studies about conservation priorities have so far been undertaken in the area of study and there was only little general socio-economic geo-data available.

The eco-regional analysis was done in the following phases:

- Delimitation of the study area

- Selection of variables

- Collection of ecological and socio-economic geo-data

- Representation of variables in geographic maps (SIG) and their classification

- Conduction of an integrated analysis of variables 


\section{ECOREGIONAL ANALISIS}

D

P
R
O
C
E
D
U
R
E

$\mathbf{R}$
$\mathbf{E}$
$\mathbf{S}$
$\mathbf{U}$
$\mathbf{L}$
$\mathbf{T}$
$\mathbf{S}$

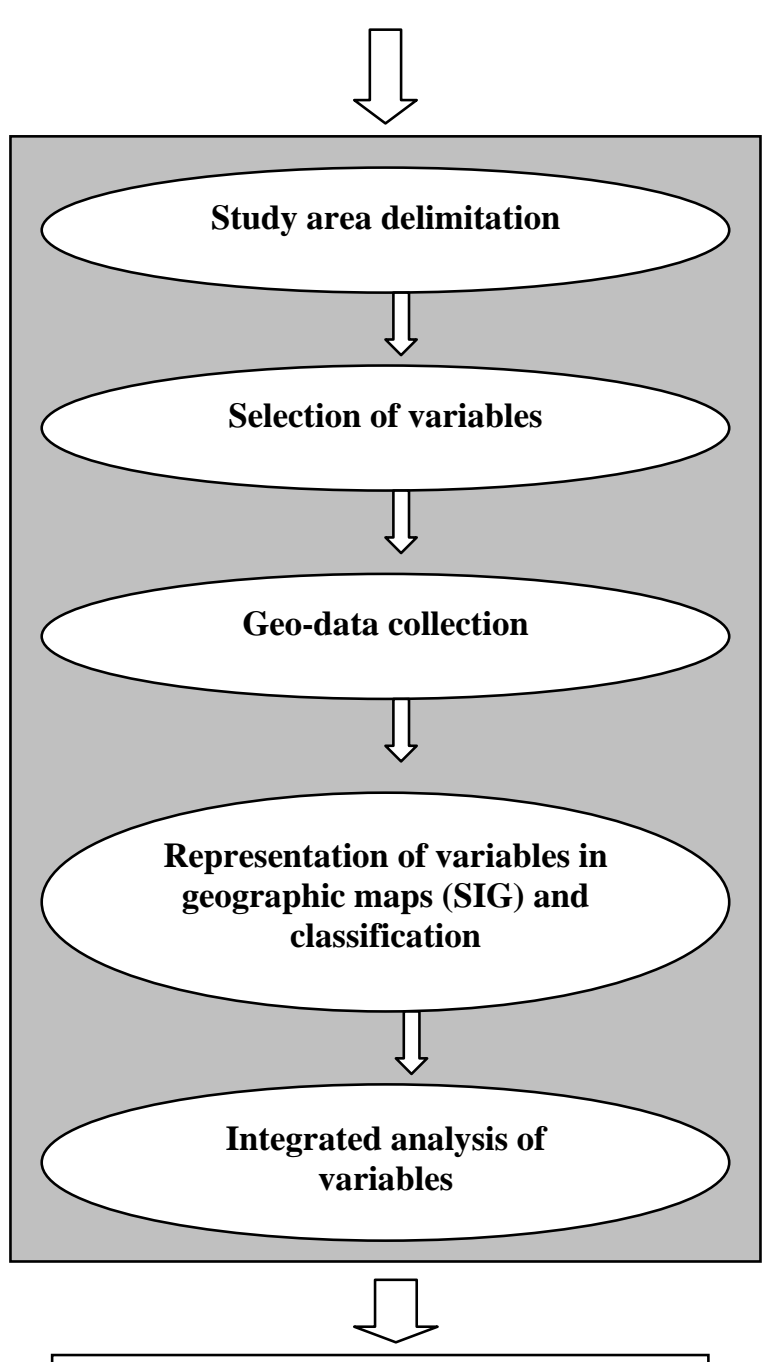

1. Ecological and socio-economic characterization of the study area

2. Places with high conservation priority

\section{CASE STUDY}

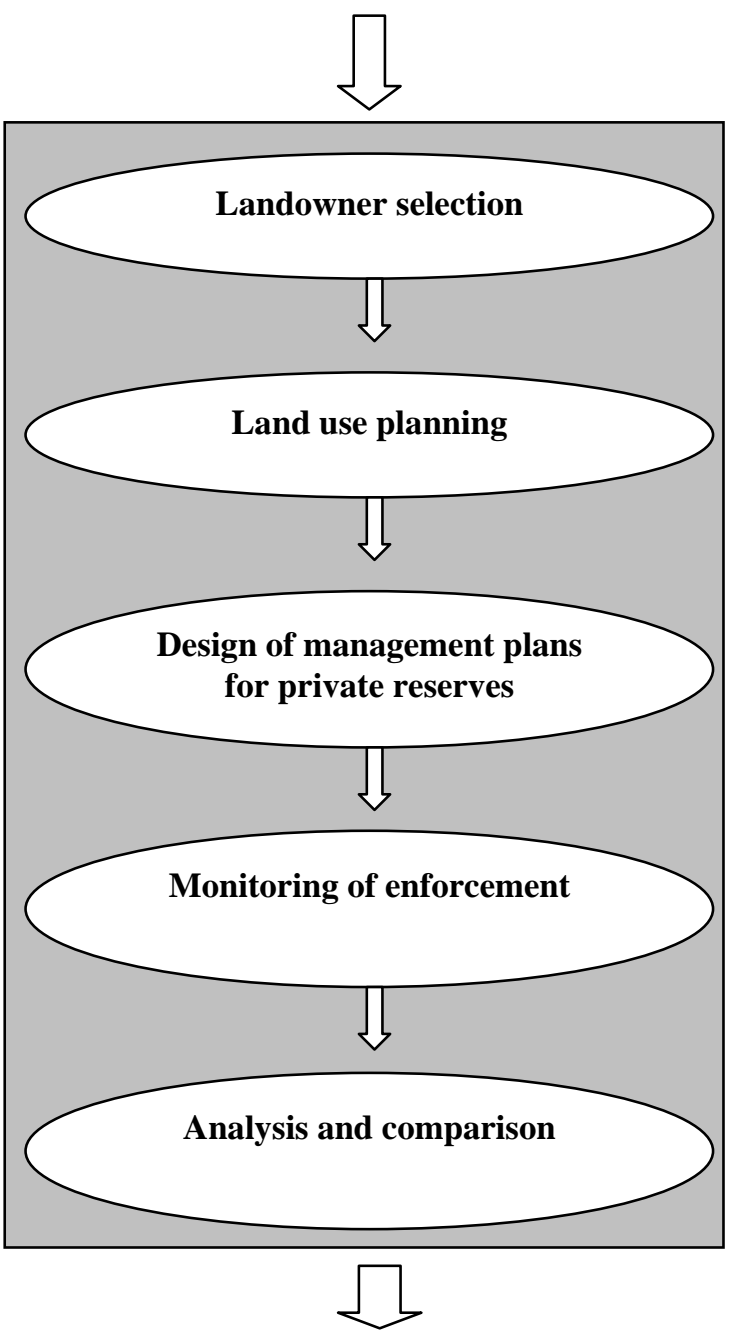

1. Landowners' predisposition to participate in biodiversity conservation

2. Identification of the main factors for conservation on private land

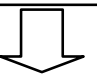

\section{Comprehensive evaluation of the potential for biodiversity} conservation on private lands in places with high priority<smiles>C1C2CC3CC1C23</smiles>

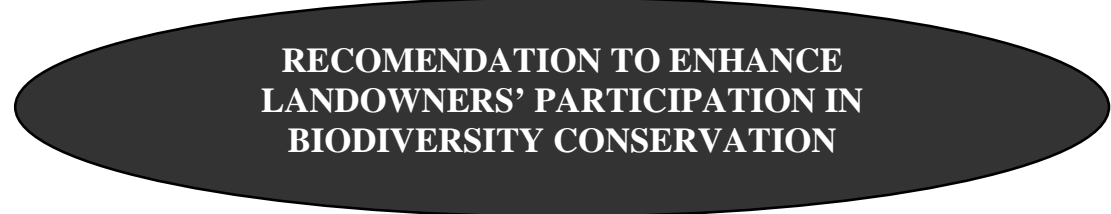




\subsubsection{Study area delimitation}

The study area was selected on the basis of the "Management Plan for the Chiquitano Dry Forest" (Ibisch et al. 2002), which recommends to carry out studies about the potential of private land conservation in the Municipality of San Ignacio, which corresponds to the zones B1 and B2 of this management plan (see annex 4 and 5). The purpose of promoting conservation on private land in this region is to maintain the connectivity between the Chiquitano Forest and the Amazon Forest.

As an initial and general reference, the San Ignacio Municipality's political boundaries were considered, and then the limits of the study area were adjusted giving priority to the main block of Chiquitano Forest. As a consequence, the study area has the following boundaries:

- North: Southern boundary of the Noel Kempff Mercado National Park and the Forest Reserve of Bajo Paragua

- South: Southern political boundary of the San Ignacio-Municipality

- East: International boundary between Bolivia and Brazil

- West: Road between San Ignacio and Santa Rosa and between Santa Rosa de la Roca and Florida

These limits were used as a reference to define the study area and make a grid, which was used to display the ecological and socio-economic data. Every square has a surface of $2 \times 2$ geographic minutes. The grid was made using the script "View.CreateMapgridTheme" and the programme Arcview 3.2. The following geographical coordinates were considered as initial point: 61.70 degrees east longitude and 16.90 degrees south latitude.

\subsubsection{Selection of variables}

Four ecological and four socio-economic variables were selected for the eco-regional analysis. The most important criterion for the selection was the availability of geographical data. The selected variables are:

Ecological variables:

- Species diversity, estimated on basis of vegetation

- Natural corridors

- Forest cover

- Protection of basins 
Socio-economic variables

- Impact of human populations

- Impact by access via roads

- Impact of land use

- Impact of forest extraction

\subsubsection{Geo-data collection}

Available geographical information was collected from secondary sources like governmental institutions, NGOs and other studies. The main sources of geo-information were:

- Scientific reports and geographical information from the "Plan for the Conservation and Sustainable Development of the Chiquitano Dry Forest, Pantanal and Bolivian Cerrado" (Ibisch et al. 2002),

- Geographical data from the Unit for Environmental Monitoring, Foundation for the Conservation of the Dry Chiquitano Forest,

- Geo-data of the Laboratory for Environmental Information. Friends of the NatureNoel Kempff Mercado Foundation (FAN-Bolivia),

- Geographical data of the rural cadastre from Bolivia provided by Instituto Nacional de Reforma Agraria (INRA),

- Information from land-use plans of the Agrarian Bolivian Superintendence (SIA),

- Project Minga, San Ignacio de Velasco, Santa Cruz,

- Unit for Forest Management of the Municipality of San Ignacio de Velasco,

- Topographic maps of the Army Institute of Engineering,

- Census for population and housing (2002), National Statistic Institute,

- Shuttle Radar Topography Mission, National Aeronautics and Space Administration (NASA) and Topography Mission (USGS online 2004),

- The Tropical Rain Forest Information Center (TRFIC online 2004). 


\subsubsection{Representation and classification of variables in geographic maps}

\subsubsection{Basic concepts about geographic data}

There are two main models for storing and representing spatial data in a Geographic Information System (GIS), the raster and the vector models (see figure 10):

- vector data: in a vector data model, real earth features are represented as either points, lines or polygons. Vector data can be used to represent linear features such as roads, streams or area edges and can be combined with raster data for display purposes or for analysis.

- raster data: In a raster model, real world features are represented as cells, which are also referred to as pixels. A pixel is usually square and many contiguous pixels are referred to as a grid. Raster (or grid cell type) data can be used for analysing, overlaying, and modelling real features such as soil types or forested areas. Raster data are generally typically scanned in from maps.

In general, raster maps are faster, vector maps are more specific and more accurate (Burrough \& McDonnell 1998).

Figure 10: Raster and vector representation of spatial fields

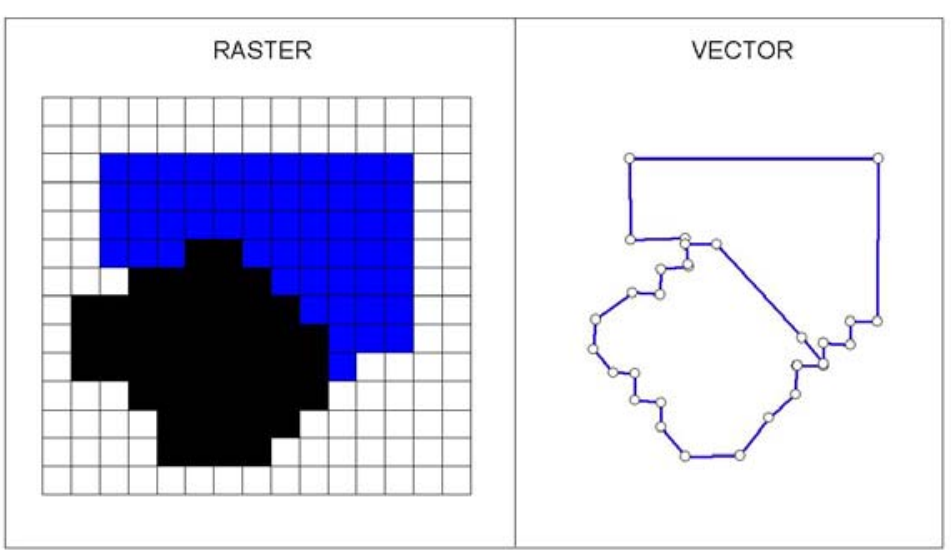


In this study, basically the rastorisation of vector data was carried out in order to arrange distinct types of data (socio-economic and ecological data) so that they can be analysed together (figure 11).

Figure 11: Example of rasterisation

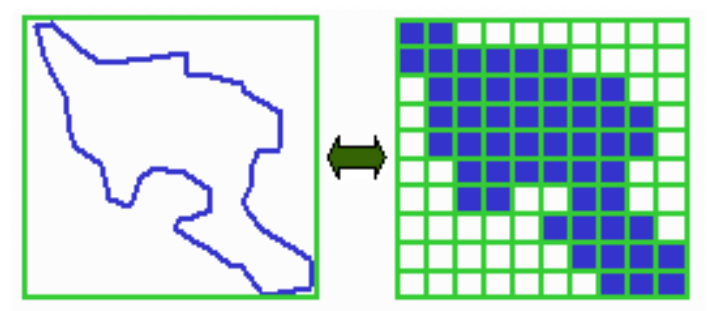

The eco-regional analysis is based on the thematic maps. The method to produce the thematic maps consists in the transference of information from the source layer into a grid layer through overlapping of the available vector GIS maps with the for the study area constructed raster GIS layer. The detailed description of calculation is given below.

\subsubsection{Data representation}

In the first step, the data of an existent layer is transferred onto an empty grid layer. Every grid element of the new layer (cells of $2 \times 2$ minutes, about $3,8 \mathrm{~km}^{2}$ ) receives a value, which comes from the original source and is being weighted accordingly to its portion of overlap with each original value. The result of this step is called "numeric weighted value (NWV)" (Armijo \& Chivé 2002).

Three typical cases to obtain the NWV will be described in the following section.

i. In the first case, the whole square surface of the new grid is covered by a single determined value of the original data source, therefore the NWV of this grid cell is the same as that of the source data because it has $100 \%$ of overlap (see the following scheme).

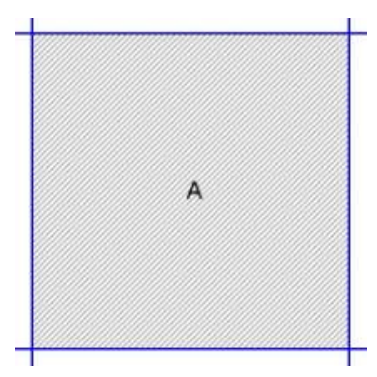


ii. In a second case, the square surface is covered by two or more values, therefore the NWV is calculated considering the weight (participation) of each present value. The final result of NWV is obtained through a mathematical weighing as can be seen in the following example.

Formula:

value of square $=$ value $1 * \frac{\text { overlap } 1}{100}+$ value $2 * \frac{\text { overlap } 2}{100}+\ldots$...value $N * \frac{\text { overlap } N}{100}$

Where: Weight $1+$ weight $2+\ldots \ldots+$ weight $\mathrm{N}=100 \%$

Calculation:

In the following example four different values overlap in one grid cell

\begin{tabular}{|c|c|c|}
\hline Range & Value & $\begin{array}{c}\text { Weight }(\% \\
\text { Participation) }\end{array}$ \\
\hline A & 475.0 & 72.82 \\
B & 19.1 & 18.01 \\
C & 12.3 & 6.45 \\
D & 0.02 & 2.71 \\
\hline Total & & 100 \\
\hline
\end{tabular}

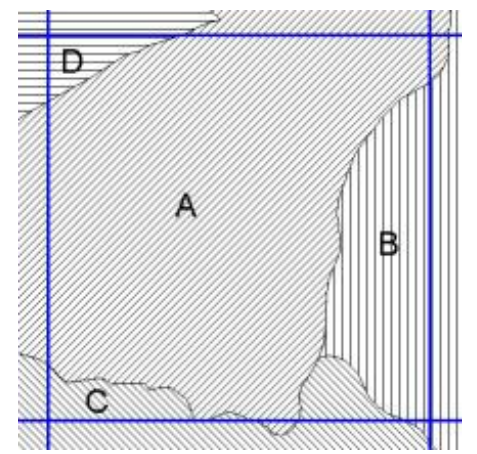

value of square $=475.0 * \frac{72.82}{100}+19.1 * \frac{18.01}{100}+12.3 * \frac{6.45}{100}+0.02 * \frac{2.71}{100}=347.46$

iii. The third case occurs when there is a part of the square surface without any corresponding data, which may occur especially at the border of the study area. In this situation, the vacuum was not considered and the total valid surface is taken as $100 \%$. The calculation of the NVW is the same as in the second case described above. This procedure was chosen in order to avoid a lack of data and as a consequence a wrong interpretation of the situation.

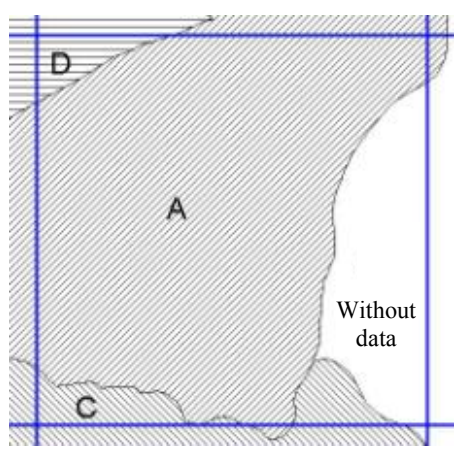




\subsubsection{Data classification}

In the second step, the NWVs are classified by the assignation of a new value from 1 to 5 , and these new values are used by the analysis. The value 1 represents the worst conditions for conservation and 5 represents the best. The classification is done according to the criteria of every variable and will be described in the following sections.

\section{a. Ecological and biological variables}

\section{a1. Biological diversity estimated on the basis of vegetation units and topographic variation}

When focusing the aims of this study, the need arose for a map of the distribution of the biological values in order to identify areas with high priority for conservation. Unfortunately, the putting together of this map entails great complexity and more requirements of economical and human resources than available during this study (for example, see Reichle et al. 2002a). Therefore, it was decided to make a simpler map, taking into consideration only two factors: vegetation units and topographic variation.

The outcome (map) of this procedure is a map of the estimated biological diversity, which is acceptable for this study, however it is possible to achieve a more exact result if other factors are added, for instance, species' distribution, climatic factors, etc.

The following procedure was applied to obtain a map of the distribution pattern of the biological diversity in the study area.

\section{i. Design of a vegetation map of the study area}

Satellite LANDSAT TM imagery were used to produce the vegetation map. The images were classified through the procedure of supervised classification with the software ERDAS 8.4.

Ten visible vegetation units were identified, as can be seen in Table 9. The unit differentiation was done according to the classification of vegetation proposed by the "Plan for the Conservation of the Chiquitano Dry Forest, Pantanal and Bolivian Cerrado" (Guillén et al. 2002), the Management Plan of the Noel Kempff Mercado National Park (FAN \& TNC, 1996), and in addition, the classification of the eco-regions of Bolivia proposed by Ibisch et al. (2004a).

Some vegetation units were not visible because of their small surface and/or their similarity with other bigger units and as a consequence they were "swallowed" by the bigger units. 
Every vegetation unit received a code composed of letters and numbers, for instance, the vegetation units located in the eco-region Chiquitano forest have "Chi" as their code; in the eco-region Cerrado: Ce, etc (see Table 7).

Table 9: Identified vegetation units and estimated units in the study area

\begin{tabular}{|c|c|c|c|}
\hline Ecoregion & $\begin{array}{l}\text { Vegetation unit in the } \\
\text { vegetation map }\end{array}$ & Code & $\begin{array}{l}\text { Small Vegetation units not to } \\
\text { differentiate or illustratable, } \\
\text { therefore appearing in the same } \\
\text { color as the large vegetation unit }\end{array}$ \\
\hline \multirow[t]{2}{*}{ Chiquitano forest } & $\begin{array}{l}\text { Lowland Chiquitano } \\
\text { Forest }\end{array}$ & Chi.1 & Chiquitano Gallery Forest \\
\hline & $\begin{array}{l}\text { Flooded Chiquitano } \\
\text { Forest }\end{array}$ & Chi.2 & \\
\hline $\begin{array}{l}\text { Southwest Amazon } \\
\text { Forest }\end{array}$ & $\begin{array}{l}\text { Humid Evergreen } \\
\text { Amazon forest }\end{array}$ & Am.1 & $\begin{array}{l}\text { Forest of Lianas, Flooded Forest, } \\
\text { Gallery Forest }\end{array}$ \\
\hline \multirow[t]{3}{*}{$\begin{array}{l}\text { Cerrado of Chiquitano } \\
\text { region }\end{array}$} & Wooded Cerrado & Ce.1 & $\begin{array}{l}\text { Treed Savanna, Flooded Treed } \\
\text { Savanna, Saxicola Vegetation }\end{array}$ \\
\hline & Open Wooded Cerrado & Ce. 2 & Open Wooded Savannas \\
\hline & $\begin{array}{l}\text { Open Savanna of } \\
\text { Cerrado }\end{array}$ & Ce.3 & \\
\hline $\begin{array}{l}\text { Pantanal Flooded } \\
\text { Savanna }\end{array}$ & $\begin{array}{l}\text { Pantanal Flooded } \\
\text { Savanna }\end{array}$ & Pa.1 & \\
\hline \multirow[t]{3}{*}{$\begin{array}{l}\text { Amazon Flooded } \\
\text { savanna }\end{array}$} & $\begin{array}{l}\text { Amazon Flooded } \\
\text { savanna }\end{array}$ & Sa.1 & Amazon Forest Islands \\
\hline & $\begin{array}{l}\text { Open Amazon Flooded } \\
\text { Savanna }\end{array}$ & Sa.2 & \\
\hline & $\begin{array}{l}\text { Aquatic vegetation } \\
\text { (rivers, lakes and } \\
\text { marshes) }\end{array}$ & Sa.3 & $\begin{array}{l}\text { Colchal, Taropal, Camalotal, } \\
\text { Arrocillar, Junquillar, etc }\end{array}$ \\
\hline
\end{tabular}

\section{ii. Valuation of the vegetation units}

The valuation of the vegetation was done by counting the number of vegetation units present in each grid square. Vegetation units with a surface of less than 150 ha were not taken into consideration. The highest counted number of vegetation units was six.

Based on the diversity values encountered, the following valuation was established:

Table 10: Valuation categories of vegetation units

\begin{tabular}{|l|c|c|}
\hline Criteria & Value & Diversity \\
\hline The square represents 6 vegetation units & 5 & Very high \\
\hline The square represents 5 vegetation units & 4 & High \\
\hline The square represents 2-3 vegetation units & 3 & Moderate \\
\hline The square represents 2 vegetation units & 2 & Low \\
\hline The square represents 1 vegetation units & 1 & Very low \\
\hline
\end{tabular}




\section{iii. Valuation of the topographic variation}

According to some studies (Ibisch et al. 2000 and 2002, Araujo et al. 2000, Sommer et al. 2003) there is a positive correlation between topographic variation and species richness; this correlation is explained by the fact that in an irregular topography there reign different conditions of humidity and temperature and, as a consequence, a high diversity of different habitats for plant and animal are formed on a relatively small scale.

In order to assess the topographic variation, a topographic map of the study area was created with the use of a Digital Elevation Model (DEM), which was obtained from the Shuttle Radar Topography Mission (USGS online 2004). The DEM were processed with the software ERDAS 8.4, through the procedure of "Topo Analysis/Raster Contour".

The valuation of every cell was done by computing the number of different altitudinal curves present, the cells with the highest number of different altitudinal curves then received the highest value. Based on the given data the following categories where created:

Table 11: Valuation categories of topographic variation

\begin{tabular}{|l|c|c|}
\hline Criteria & Value & Topographic diversity \\
\hline $9-12$ altitudinal curves present & 5 & Very high \\
\hline $6-8$ altitudinal curves present & 4 & High \\
\hline $4-5$ altitudinal curves present & 3 & Moderate \\
\hline 3 altitudinal curves present & 2 & Low \\
\hline Less than 3 altitudinal curves present & 1 & Very low \\
\hline
\end{tabular}

\section{iv. Estimated Biological diversity}

The valuation of the vegetation units and the topographic variation were combined through a simple addition in a single map. The outcome was then classified in ranges, as can be seen in Table 12. The result of this procedure allows to obtain a map of the "Estimated biological diversity".

Table 12: Valuation of biological diversity

\begin{tabular}{|l|c|c|c|}
\hline Criteria & Range & Value & Biological diversity \\
\hline Combination of the following data layers: & $>7$ & 5 & Very high \\
\cline { 2 - 4 } diversity of vegetation units and & 6 & 4 & High \\
\cline { 2 - 4 } topographic variation & 5 & 3 & Moderate \\
\cline { 2 - 4 } & 4 & 2 & Low \\
\cline { 2 - 4 } & $<4$ & 1 & Very low \\
\hline
\end{tabular}




\section{a2. Natural corridors}

According to Reichle et al. (2002a) the variable "natural corridors" allows to underline the value of some ecosystem structures (e.g. riverine forests and hills) that ease the shift and dispersion of organisms.

In the study area, there are two kinds of natural corridors: gallery forests (forests along a river or stream) and mountain ranges (series of mountains higher than $500 \mathrm{~m}$ ). These structures were included in the analysis through the representation of these features in the grid layer.

The following procedure was applied: the presence of gallery forest or mountains was identified in every cell. After that, the cells were collapsed in the following manner:

Table 13: Valuation of natural corridors

\begin{tabular}{|l|c|c|}
\hline Criteria & Value & Interpretation \\
\hline Gallery forest (North - South direction) & 3 & Moderate \\
\hline Gallery forest (West - East direction) & 2 & Low \\
\hline Mountains between $500-1000 \mathrm{~m}$ & 1 & Very low \\
\hline Mountains higher than $1000 \mathrm{~m}$ & 1 & Very low \\
\hline
\end{tabular}

\section{a3. Forest cover}

This variable highlights the significance of large extensions of homogeneous forest, which represents minimal spaces of unique species' habitats. Vast forest areas have also a major importance for the local climate and the hydrologic behaviour and, in addition, they function as parts of biological corridors (Reichle et al. 2002a).

The procedure to include this variable into the analysis was as follows: the percentage of forest area in each cell was calculated and the cells with a forest cover higher than $80 \%$ were selected to give them a value of "two". The rest of the cells received a value of "zero" (see table 14).

Table 14: Valuation of forest cover

\begin{tabular}{|l|c|c|}
\hline Criteria & Value & Interpretation \\
\hline Cell with forest cover under $80 \%$ & 0 & low \\
\hline Cell with forest cover over $80 \%$ & 2 & high \\
\hline
\end{tabular}




\section{a4. Protection of basins}

The protection of basins was taken into consideration in order to underline the function of forest areas in highlands by protecting the catchment, which is important to the regulation of the hydrology of the area. The procedure of the valuation of this factor consisted in the identification of high catchment areas and after that, one point is added to the value of each corresponding cell, as can be seen in table 15 .

Table 15: Valuation of protection of basins

\begin{tabular}{|l|c|c|}
\hline Criteria & Value & Protection of spring \\
\hline Presence of forest in catchment basins & 1 & Very low \\
\hline
\end{tabular}

\section{b. Socio-economic variables}

\section{b1. Impact of human populations}

This variable was taken into account to show the human population's influence on natural ecosystems. It was assumed that the higher the population density, the higher is its impact on nature.

The process to assess the human impact consisted in the determination of the correct distribution of population density in the study area; the analysis was done in the following way:

The first step was the determination of the population density of the two main urban places, San Ignacio and Santa Ana. From the examination of the satellite images it was assumed that these towns had a circular shape. The diameter average of each town was established with the use of GIS (San Ignacio $=5 \mathrm{~km}$ and Santa Ana $=2 \mathrm{~km}$ ). The town surface was then calculated with the formula: "surface $=$ ratio $^{2} \pi$ ". Finally, the urban population data from the census 2002 (INE, 2003) was divided by the calculated surfaces of each town, establishing the population density.

The second step was the calculation of the rural population density. The rural area was divided in two parts: an area with communal influence (i.e. places where farmers and their families are developing their activities for living) and an area with less human influence (areas far away from the community). In order to have the best approach to the real distribution of the population, it was assumed that the communities' main centres have a circular shape and a diameter of one $\mathrm{km}$. Rural population data from the census 2002 and a 
geo-referenced layer of the present communities in the study area were used to establish the human impact. $95 \%$ of the rural population of the municipality was assigned to the community-influenced area and the rest (5\%) to the area with less human influence. The rural population density was determined in the same way as the population town density (population divided by surface).

A map of population density was made with the results of these two steps and after that transference of values was undertaken from the map of population density to an empty grid layer. The cell classification was then collapsed in the following manner:

Table 16: Population density valuation

\begin{tabular}{|l|c|c|c|}
\hline Criteria & $\begin{array}{c}\text { Range } \\
\text { (inhabitant/ } \mathbf{k m}^{\mathbf{2}} \text { ) }\end{array}$ & Value & Interpretation \\
\hline Population density & $95.3-187.0$ & 5 & Very high \\
\cline { 2 - 4 } & $33.0-95.3$ & 4 & High \\
\cline { 2 - 4 } & $12.1-33.0$ & 3 & Moderate \\
\cline { 2 - 4 } & $4.4-12.1$ & 2 & Low \\
\cline { 2 - 4 } & $<4.4$ & 1 & Very low \\
\hline
\end{tabular}

The values of population density are only valid for this region.

\section{b2. Impact by access via roads}

The presence of roads is considered to facilitate the access of economic development and human settlement, for this reason, roads are taken as an indicator of human impact, especially in isolated areas.

The current roads in the study area were classified into four types:

- International and interstate roads: they link the region with other states and countries (in this case Brazil) and they are normally permanently passable by cars.

- Inter-provincial roads: they link the region with other provinces and municipalities, less passable by cars.

- Regional roads: they link the main human centres within the region, they have one lane and are normally impassable in the wet season.

- Local roads: they link the communities and ranches and have only one lane.

The first stage of the valuation the impact of roads consisted in overlapping an empty grid layer with the layer of the international and interstate roads; the cells that coincide with the mentioned roads received the maximum value of impact (five), as can be seen in the following table. 
Buffer zones were computed for the rest of the roads categories and the coincidental cells were classified in the following way:

Table 17: Criteria and categories for the valuation of the impact of roads

\begin{tabular}{|l|c|c|c|}
\hline Criteria & Buffer zone & Value & Interpretation \\
\hline Presence of international or interstate road & 0 & 5 & Very high \\
\hline Inter-provincial roads & $1 \mathrm{Km}$ & 4 & High \\
\hline Regional roads & $0.5 \mathrm{Km}$ & 3 & Moderate \\
\hline Local roads & $0.5 \mathrm{Km}$ & 2 & Low \\
\hline
\end{tabular}

In several cases there existed an overlapping of buffer zones (especially in the road crossing), and the impact intensity was overestimated, for this reason, in those cases, the cells received the value of the road with the highest impact value.

\section{b3. Impact of land use}

The land use changes due to human activities are important factors that disturb natural ecosystems and therefore they have to be included in the present eco-regional analysis. The procedure applied to characterize the estimated impact of land use was done in the following way:

A satellite image (Landsat) of 2002 was processed with the software ERDAS 8.4 in order to identify deforested areas. These data were put on a grid layer and deforestation percentages of every cell was then computed. Cells with higher percentage than $10 \%$ were classified according to the categories of table 18 .

Cells with deforestation on less than $10 \%$ of its surface were classified according to livestock production criteria because extensive livestock is one of the most important economic activities in the study-area.

Open areas (savannas) and semi-open areas (treed savannas) were identified in the satellite image; by overlapping the different layers corresponding cells were summarized according to the criteria of table 18 .

Furthermore, towns, communities and ranch influence zones were included as livestock areas. For this objective, a buffer zone of five kilometres (outside of the populated area) was 
assigned for those places in order to estimate the impacted area. These data were put on the grid layer and afterwards the cells were collapsed according to the ranges of table 18 .

Table 18: Criteria for valuation of land use impact

\begin{tabular}{|l|c|c|}
\hline Criteria & Value & Interpretation \\
\hline Cells with deforestation $>30 \%$ & 5 & Very high \\
\hline Cells with deforestation $10-30 \%$ & 4 & High \\
\hline Open and semi-open areas with cultivated grass & 4 & High \\
\hline Outskirts of towns, communities and ranches & 3 & Moderate \\
\hline Open and semi-open areas & 2 & Low \\
\hline
\end{tabular}

In order to avoid cell overestimation, the classified cells with more than one criterion were weighted accordingly.

\section{b4. Impact of forest production}

There are forest areas in the study space that are managed by local groups called "ASL". The forest activities cause less damage to natural ecosystems than other human activities, however, they have an impact on natural habitats.

During the realization of this study there were no forest activities in the mentioned forest areas, but informal news indicated non-reported extraction of wood and also illegal trade of wood. For this reason, the estimated impact of the forest activities was taken into consideration. The evaluation was done according to the criteria of Table 19.

Table 19: Valuation of forest activities

\begin{tabular}{|l|c|c|}
\hline Criteria & Value & Interpretation \\
\hline Forest areas within ASL & 2 & low \\
\hline
\end{tabular}

\section{d. Analysis of the situation of land property and legal restrictions of land-use}

\section{d1. Land property situation}

The analysis of the situation of land property was an important part of this study because legal framework of land determines possibilities for private land conservation. The legal situation of the land was taken into account by producing a map of the land properties on the basis of official data and data collected directly from the region.

Three categories of land were identified in the region: 
- Forested and protected areas (belong to the government)

- Community land

- Private land

For the analysis, a classification of this land was prepared. First, the community land was broken down in the following ranges:

Table 20: Classification ranges of community land

\begin{tabular}{|l|c|}
\hline Classification & Range (ha) \\
\hline Large & $>10,000$ \\
\hline Medium & $4,000-10,000$ \\
\hline Small & $700-4,000$ \\
\hline Very small & $<700$ \\
\hline
\end{tabular}

Private land was grouped in the following ranges:

Table 21: Classification ranges of private land

\begin{tabular}{|l|l|}
\hline Classification & Range (ha) \\
\hline Very large & $>10,000$ \\
\hline Large & $5001-10,000$ \\
\hline Medium & $2,001-5,000$ \\
\hline Small & $2,000-700$ \\
\hline Very small & $<700$ \\
\hline
\end{tabular}

\section{d2. Legal restrictions of land-use}

In the study area, restrictions created by government regulations limit land use both in public and private lands. Hence, maps of the spatial distribution of these regulations were produced on the basis of available geo-information. The major government dispositions that affect the human land intervention in the study zone are the General Land Use Plan of the Santa Cruz Department and the Administrative Conservation Easements under Bolivian Forestry Law (Law No 1700). 


\subsubsection{Integrated Analysis of variables}

\subsubsection{Biological-ecological valuation}

This type of valuation describes the biological and ecological value of a natural area without considering the human influence or impact (Reichle et al. 2002a). The biological-ecological valuation consisted of the integration of the values of biological and ecological variables. For this purpose the calculated values in the grid layers were added per grid cell in GIS and the outcome was collapsed in the way that can be seen in table 22.

Table 22: Classification criteria of the biological-ecological valuation

\begin{tabular}{|l|c|c|c|}
\hline Criteria & Range & Value & Interpretation \\
\hline Addition of following variables: & $>10$ & 5 & Very high \\
\cline { 2 - 4 } Estimated Diversity, & $9-10$ & 4 & High \\
\cline { 2 - 4 } Natural Corridors, & $7-8$ & 3 & Moderate \\
\cline { 2 - 4 } Forest cover and & $5-6$ & 2 & Low \\
\cline { 2 - 4 } Protection of basins & $<5$ & 1 & Very low \\
\hline
\end{tabular}

\subsubsection{Conservation status}

According to Ibisch et al. (2000, 2002a), the conservation status describes the condition of biodiversity of an area; this status is a result of human activities, which entails partial or total ecosystem degradation.

The conservation status of the study area was made through the addition of the values of socio-economic variables, which were computed in the previous steps. The new values were classified in ranges and collapsed according to table 23.

Table 23: Classification criteria of the conservation status

\begin{tabular}{|l|c|c|c|}
\hline Criteria & Range & Value & Interpretation \\
\hline Addition of following variables: & $<2$ & 5 & Very good \\
\cline { 2 - 4 } Impact of human populations & $2-4$ & 4 & Good \\
\cline { 2 - 4 } Impact by access via roads & $5-6$ & 3 & Moderate \\
\cline { 2 - 4 } Impact of land use & $4-10$ & 2 & Critical \\
\cline { 2 - 4 } Impact for forest extraction & $>10$ & 1 & Very critical \\
\hline
\end{tabular}




\subsubsection{Spatial priorities}

The integration of the biological-ecological valuation and the conservation status allows to obtain a preliminary map of spatial priorities that shows the most important areas for conservation biodiversity in the study area. However, this map is preliminary because of the necessity to contrast the results with legal factors like the distribution of the properties of the land.

The procedure to obtain the mentioned map consists in the mathematic addition of the values of the cell and their classification in ranges, as can be seen in table 24. As a consequence, the locations of higher priorities are located in areas with very high biological-ecological valuation and very good conservation status.

Table 24: Ranges and criteria for spatial conservation priorities

\begin{tabular}{|c|c|c|c|}
\hline Criteria & Range & \begin{tabular}{|l|} 
Value \\
\end{tabular} & Interpretation \\
\hline \multirow{5}{*}{$\begin{array}{l}\text { Addition of following variables: } \\
\text { biological-ecological valuation and } \\
\text { conservation status }\end{array}$} & $>8$ & 5 & Very high \\
\hline & 8 & 4 & High \\
\hline & 7 & 3 & Moderate \\
\hline & $5-6$ & 2 & Low \\
\hline & $>5$ & 1 & Very low \\
\hline
\end{tabular}

\subsubsection{Construction of a preliminary conservation vision}

The final step of the eco-regional analysis was the construction of a preliminary map of a conservation vision. This was done through the integration of the following maps:

- the map of spatial priorities (chapter 4.1.5.4.)

- the map of land property situation (chapter 4.1.4.3. "d") and, in addition, the official land use planning categories established by the government (Plan de uso de suelo, PREFECTURA DPTO SANTA CRUZ 1996)

- the map of the proposed planning of the Plan for the Conservation of the Chiquitano Dry Forest, Pantanal and Bolivian Cerrado (annex 4).

The geographical overlapping of those data allowed the delimitation of zones, which receive an individual use recommendation according to the objectives of biodiversity conservation and maintenance of connectivity. 
The preliminary map of a conservation vision is a tool used to identify areas with high priority for conservation differentiating the recommended areas for conservation on private land. This map is an adequate outcome that could be used as a guideline for major planning processes.

\subsection{Case study}

The case study is a method that encompasses an intensive analysis of an individual unit (as a person or community) stressing developmental factors in relation to the environment (Black, 1999; Bernard, 2000). Qualitative and quantitative information from particular instances can be obtained through this method, but the results and their conclusions cannot be generalized to the population under investigation.

A case study of the attitude of the landowners was undertaken in order to understand and systematize their predisposition to take part in biodiversity conservation. This method was preferred because it allowed the involvement of the landowners in a real situation of land use planning, where the proposal of separating a part of their land for biodiversity was discussed and analysed. In contrast to this method, the use of a common quantitative method (for instance a survey) would have been less effective, because the possible given answers would be made under hypothetical circumstances. In addition, logistic factors like the long distances, the geographical dispersion of the ranches and the fact that landowners usually do not live on their ranches determined the use of this method.

The case study was carried out in the following steps:

\subsubsection{Landowner selection}

The landowners were selected on basis of the following criteria:

- Private landowners

- Willingness to establish private reserves

- Ranch location in areas with high conservation priority

- Location in different eco-regions

- Land-ownerships' conservation status

- Land tenure 


\subsubsection{Private landowners}

According to the analysis of the situation of land tenure carried out in the first part of this work, $83.87 \%$ of the registered land in the study area is in the hands of private landowners, therefore they were chosen as target-group to evaluate the potential of conservation on private land. Communities of indigenous people control a part of the land and they are basically private owners too. However the methods to study their attitudes and decisions should be different, for this reason and economic limitations of the study they are not involved in this study. However, the realisation of a specific study about the participation of these people in biodiversity conservation is highly justified.

In order to select the landowners, the following definition was assumed to separate them from communal owners: Landowners are individual, familial or enterprise proprietors of rural land. On the basis of that criterion, fifteen owners were chosen for the case study, as can be seen in table 25 .

\subsubsection{Willingness to establish private reserves and to participate in this study}

Eight landowners who accepted the proposal of setting up a conservation area or private reserve on their land were selected. They accepted taking part in this study to evaluate the possible benefits that may be obtained. This group was called "group A".

On the other hand, seven landowners who did not want the establishment of private reserves were included in order to undertake a comparative analysis. This group of proprietors was called "group B".

The landowners' ranches or holdings were coded with letters and numbers, as can be seen below.

\subsubsection{Ranch location in areas with high priority for conservation}

Eight holdings (four of group A and four of group B) are located in the zone with high priority for private land conservation according to the results of the eco-regional analysis (zone B1 see 3.1.5.5). The majority of those lie close to the international-interstate road San Ignacio-San Matias, so that it was possible to consider the strong deforestation process occurring in this area as well, to avoid the difficulties to access other remote places with high priority. 
Five ranches (three of A and two of B) located in a zone recommended for extensive livestock (E1), and two (one of each group) located in a zone of agro-forest-pastoral systems (E2) complemented the group of case studies. The choice to include these ranches was made to compare the ranch situation in places with high conservation priority and potential agricultural areas.

Table 25: Codification, surface and location according to conservation priorities of holdings

\begin{tabular}{|l|r|c|}
\hline \multicolumn{1}{|c|}{ Case } & Surface (ha) & $\begin{array}{c}\text { Holding location in the } \\
\text { map of priorities }\end{array}$ \\
\hline a1-ch & 2378,90 & B1 \\
\hline a2-ch & 1932,14 & B1 \\
\hline a3-ch & 2427,52 & B1 \\
\hline a4-ch-ce & 2663,72 & B1 \\
\hline a5-ch-ce & 2774,01 & E2 \\
\hline a6-ce & 9249,20 & E2 \\
\hline a7-ch-ce & 2676,89 & E2 \\
\hline a8-sa & 13985,92 & E1,B1 \\
\hline b1-ch & 1433,75 & B1 \\
\hline b2-ch & 10369,57 & B1 \\
\hline b3-ch & 985,32 & B1 \\
\hline b4-ch-ce & 7213,37 & B1 \\
\hline b5-ce-ch & 17631,90 & E2 \\
\hline b6-ce-ch & 11710,74 & E2 \\
\hline$b 7-s a$ & 2219,10 & E1 \\
\hline
\end{tabular}

\subsubsection{Ranch location in different ecoregions}

Furthermore, ranches were chosen according to their location in the different ecoregions of the study area. For this purpose, the map of the ecoregions was used that was developed in this study and designed according to the classification proposed by Ibisch et al. (2004).

Because the study area is a transitional area, some ranches have features of more than one ecoregion, by the selection of a ranch only the larger ecoregion presented within the ranch was taken into consideration. Table 26 shows these characteristics.

In order to facilitate the recognition of the case studies, the code of each ranch contains two letters that represent the relevant eco-region as follows: $\mathrm{Ch}=$ Chiquitano Forest; $\mathrm{Ce}=$ Cerrado; $\mathrm{Sa}=$ Flooded Savanna and Am = Amazon Forest (see table 26). 


\subsubsection{Conservation status of the land}

The selected ranches had a very good conservation status, if the percentage of transformed land in agricultural areas is taken as an indicator. Thus, the chosen lands had less than $20 \%$ of intervened areas.

Table 26: Features of ecoregions presented in the selected ranches

\begin{tabular}{|c|c|c|c|c|}
\hline Ranches & \begin{tabular}{|l|} 
Chiquitano \\
Forest
\end{tabular} & Cerrado & \begin{tabular}{|l|} 
Flooded \\
Savanna \\
\end{tabular} & \begin{tabular}{|l|} 
Amazon \\
Forest
\end{tabular} \\
\hline a1-ch & $\mathrm{M}$ & & & \\
\hline a2-ch & $\mathrm{M}$ & & & \\
\hline a3-ch & $\mathrm{M}$ & & & \\
\hline a4-ch & $\mathrm{M}$ & $X$ & & \\
\hline a5-ch-ce & $\mathrm{M}$ & $\mathrm{X}$ & $\mathrm{X}$ & \\
\hline a6-ch-ce & $X$ & $\mathrm{M}$ & $X$ & \\
\hline a7-ch-ce & M & $\mathrm{X}$ & & \\
\hline a8-sa & $X$ & $X$ & $\mathrm{M}$ & $\mathrm{X}$ \\
\hline b1-ch & $\mathrm{M}$ & & & \\
\hline b2-ch & $\mathrm{M}$ & $\mathrm{X}$ & & \\
\hline b3-ch & $\mathrm{M}$ & & & \\
\hline b4-ch-ce & $X$ & $\mathrm{M}$ & $X$ & \\
\hline b5-ch-ce & $\mathrm{X}$ & $\mathrm{M}$ & $\mathrm{X}$ & \\
\hline b6-ch-ce & $X$ & $\mathrm{M}$ & $\mathrm{X}$ & \\
\hline b7-sa & $X$ & & $\mathrm{M}$ & $X$ \\
\hline
\end{tabular}

$\mathrm{P}=$ Main ecoregion; $\mathrm{X}=$ Other ecoregion present

\subsubsection{Land tenure and property rights}

The classification of land tenure was also taken into consideration in the selection of the case studies. Thereby landowners from different tenure categories were chosen, as can be seen in table 27. Only proprietors of very small areas were not included in this study because of the small number of those ownerships.

Table 27: Number of selected ranches according to the land tenure category

\begin{tabular}{|l|c|c|c|}
\hline \multicolumn{1}{|c|}{ Classification } & Range (ha) & \multicolumn{2}{c|}{ Case study } \\
\hline & & Group A & Group B \\
\hline Very low & $<700$ & 0 & 0 \\
\hline Low & $700-2,000$ & 1 & 2 \\
\hline Moderate & $2001-5,000$ & 5 & 1 \\
\hline Large & $5001-10,000$ & 1 & 1 \\
\hline Very large & $>10,000$ & 1 & 3 \\
\hline
\end{tabular}




\subsubsection{Land use planning in selected holding}

Land-use planning in the selected holdings was carried out through a participative process, in which the landowners were the central actors. The applied procedure, which is described below, was based on the guidelines of the norm for the "Predial Ordering Plan (POP)" (SIF 1997), as well other agrarian, forest and environmental norms.

The conduction of a POP is compulsory for private landowners and represents a significant cost. In order to obtain the participation of landowners, the researcher of this study offered the POP design free of charge. This resulted in great acceptance.

Undertaking a POP is basically a technical and systematic process of land classification or organization taking into account the soil's features and capabilities. The procedure is composed of two main phases: (a) a diagnosis of the soil's properties and its current use, and (b) a classification of the soil according to its capabilities and the landowner's socio-economic possibilities and projections. The classification of the soil is expressed in the following categories: (1) agricultural and livestock areas, (2) forested areas, (3) compulsorily protected land, and (4) voluntarily protected land. The POP has to be presented to the Bolivian Agrarian Superintendence, which carries out the plan's revision, approval, and the further monitoring of the POP enforcement.

In the case of the chosen landowners, the process was undertaken on the basis of an open dialogue about the land use possibilities. Technical recommendations based on the soil's diagnosis were shared with the owners, who gave their own criteria and plans for their holding. Finally, proprietors took the decision about the land-use arrangements. A summarised description of the procedure is given below.

1. Detailed explanation of land use objectives, procedures and requirements to the participant landowners.

2. Information gathering about the holding (location, UTM coordinates, general soil norms, etc) and production of a base map.

3. Field data collection (data of soil, vegetation, relieve, current land use, etc.).

4. Analysis and systematisation of the collected data and presentation of a preliminary proposal of classification to the landowners.

5. Discussion and analysis of the proposal with the owners.

6. Presentation of the POP-report to the Agrarian Superintendence.

7. Complementation and explanation of the Agrarian Superintendence's observations. 
8. POP-report delivery to the landowners.

\subsubsection{Design of a management plan for private reserves and monitoring}

Management plans for areas classified as "voluntarily protected land" or Private Reserves were made in those cases in which the landowners accepted the establishment of such an area on their property. The establishment of such management plans was done according to the technical guidelines of the General Regulation of the Forestry Law (SIF 2002).

The procedure to design a management plan is fairly similar to the procedure of the POP. In general the process consisted of (a) the gathering of data about the biological values to be conserved, (b) the planning of the activities to ensure the protection of the habitats, and (c) the definition of the pertinent voluntary protection period.

Biologists from the Museum of Natural History (Gabriel Rene Moreno University) carried out the data collection in the selected holdings. This work was done in the context of an interinstitutional project producing POPs, in which the NGO FAN-Bolivia, the Forestry Superintendence and the Agrarian Superintendence took part.

The biologists used techniques of rapid assessments, checking species lists and interviewing local people. The outcomes of this work were lists of birds and mammals, which were taken as indicators for the degree of biodiversity on every farm.

The following points present the undertaken steps of the planning procedure:

1. Detailed explanation of the objective, the importance and the procedure to establish private reserves.

2. Secondary data gathering of biological and ecological conditions.

3. Field data collection of biodiversity (flora and fauna). Exchange of criteria and landowners' ideas about the future private reserve.

4. Data analysis and design of a preliminary management proposal.

5. Presentation of the proposal and discussion with the landowners.

6. Writing the technical report.

7. Complying with the legal requirements: land titles and applications (public notary).

8. Presentation of the management plans and attached documents to Forestry Superintendence. 
9. Complementation and explanation of observations of the Forestry Superintendence's observations.

The last step to establish a private reserve is the inscription of the reserve in the governmental office for private ownership; however, in the majority of the landowners' holdings the procedure could not be finished (see chapter of results).

\section{Monitoring}

The technical process of compiling the Predial Ordering Plan and the management plan design was not difficult. Nevertheless, concern existed about the approval by the governmental institutions mentioned above and the enforcement of the planning. For these reasons, an observation period of one year was established in order to identify problems and help the landowners in solving them. 


\section{RESULTS AND DISCUSSION}

\subsection{Ecoregional analysis and conservation priorities in the study area}

\subsubsection{The macro context}

The study area should be considered as a part of a macro natural system in order to understand its priority of conservation and importance. On a macro or continental level, the area is one of the last well-conserved places of transitional vegetation between deciduous and evergreen forest in South America, as can be seen in figure 12. The significance of this area rises taking into consideration that it is the only place, where the Chiquitano Forest- endemic of Boliviaand the Amazon Forest meet geographically.

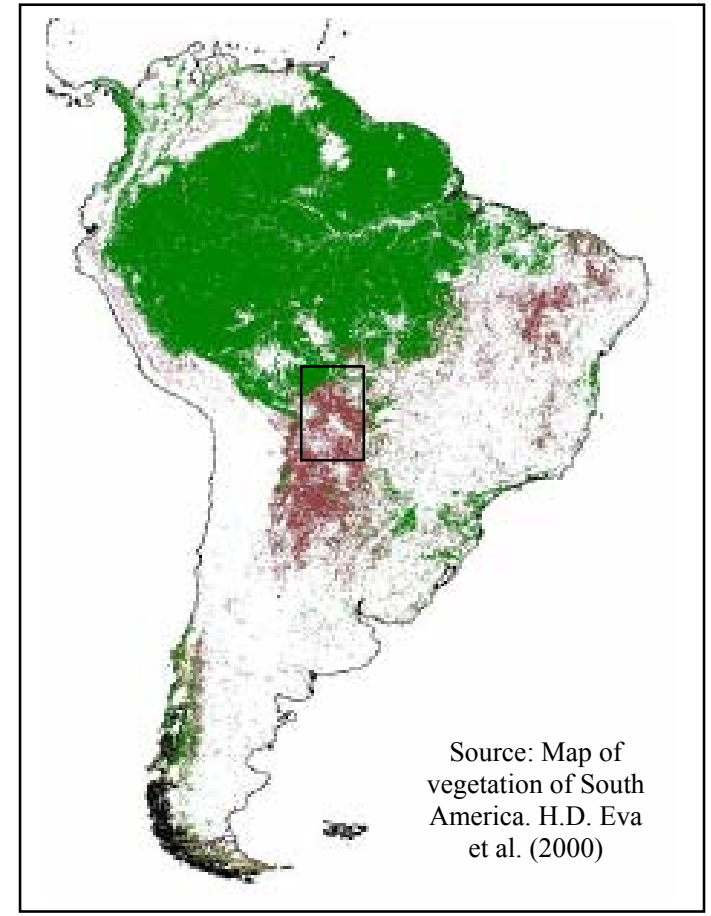

Figure 12: Location of the study area and distribution of deciduous and evergreen forest in South America

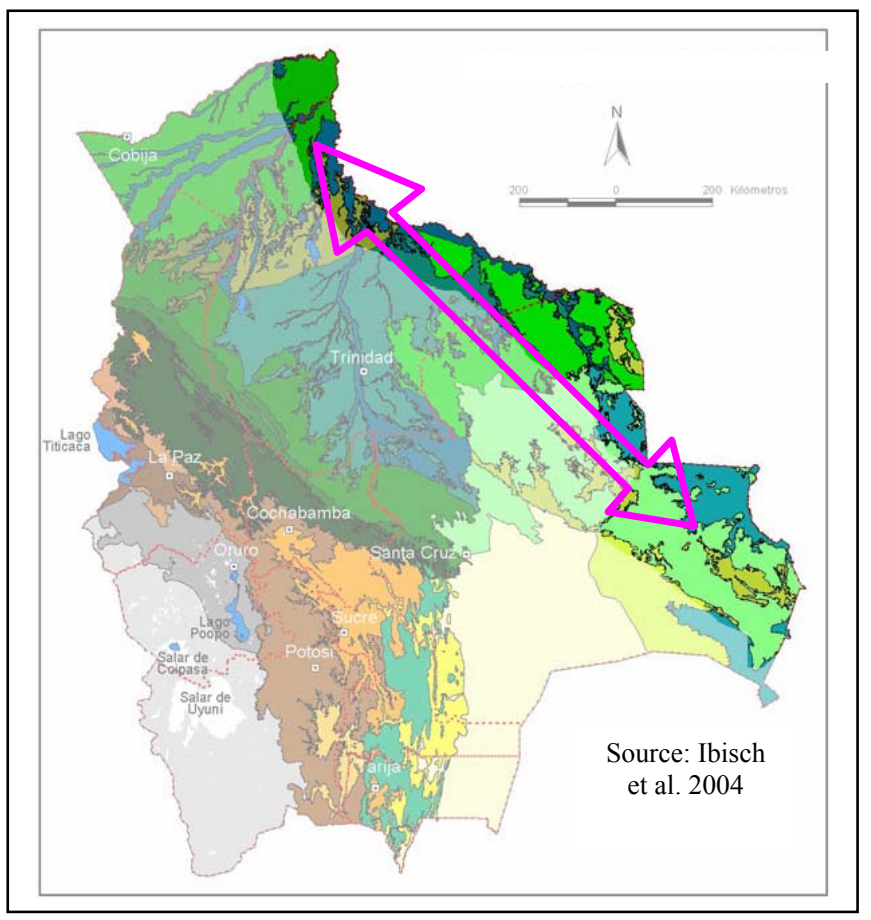

Figure 13: Chiquitano-Itenez proposed biocorridor 
Within Bolivia, the transitional region Chiquitano-Amazon occurs in the proposed "Biological Corridor ${ }^{3}$ Chiquitano-Itenez", an initiative proposed by Ibisch \& Araujo (2004) to conserve a large territory that covers the eastern side of the country and encompasses the ecoregions of Chiquitano Forest, Pantanal Flooded Savannas, the Cerrado and the South Western Amazon Forest (see figure 13). Because of a low population density, the absence of infrastructure and its location far from human settlement, these areas so far have had a good conservation status. But this situation is changing now due to strong socio-economic processes; the most frequently mentioned are the construction of the gas-pipeline that disturbed the Chiquitano Forest, the planned construction of bi-oceanic roads to connect the Pacific with the Atlantic and the political interest in a close economic integration with Brazil.

There exist only two large protected areas in the mentioned corridor: the Noel Kempff National Park and the "San Matias Natural Area of Integrated Management". Other smaller protected areas are being established with some difficulties, but they are not connected and there are concerns that they will become islands in the future.

In conclusion, the study area, in a macro view, is a strategic place to carry out conservation activities to save macro biological processes diminishing the effect of current changes, like global warming and the negative impacts of economic tendencies.

\subsubsection{The bio-ecological importance of the conservation of the study area}

The conservation of the study area is justified because of three valuable functions: (a) keyregion for connectivity, (b) biodiversity protection, (c) protection of headwaters.

\subsubsection{Connectivity}

The study area represents a bridge-territory that joins the Chiquitano Forest and the southernmost part of the Amazon Forest. The completion of the task of connectivity is possible due to the vast forest surface and the presence of rivers and streams, which have a south-north course.

\footnotetext{
3 "A natural bio-corridor is characterized by the genetic flow within its limits and generally also by the fact that the organisms that area displaced within it do not have an alternative space for their developments. The natural corridor is converted into a conservation corridor the moment that a program is established to ensure that the biocorridor does not lose the characteristics necessary to guarantee the movements and flows mentioned above" (Ibisch \& Araujo 2004).
} 
Sixty-three percent of the area show a forest cover higher than $80 \%$ and form a large continuous block (see figure 14). This property allows the existence of several habitats, where a lot of species can develop and transit. The major forest block is the Chiquitano Forest that is located in the foothills of the Chiquitano Mountain range, the second forest block, smaller than the first one and composed of flooded and gallery forest, extends from Manomo Hill to the floodplain of the Tarvo River in the north.

This block is composed of a combination of Chiquitano and Amazon vegetation without a clear boundary between both ecosystems.

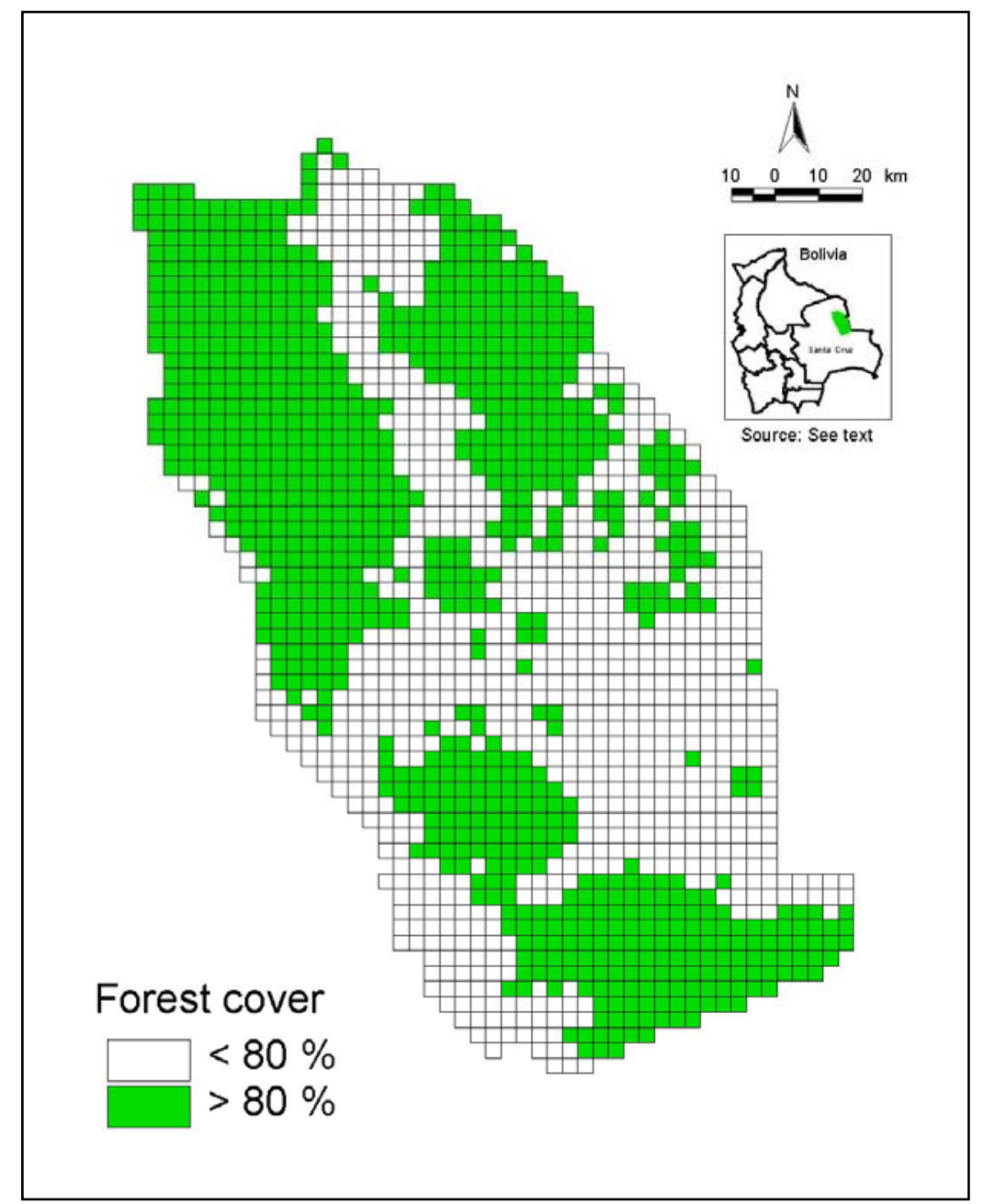

Figure 14: Forest cover of the study area

In addition to the above-mentioned property, these large areas of forest also have a high value for the local climate. They contribute to the stabilization of the rainfall distribution and the temperature variation during the year, very important aspects for cattle ranching, forest logging and agricultural activities in the region, which usually suffer from a long dry season. 
With regard to the streams, they play a key-role in allowing the migration of organisms and their diasporas. Most of the streams drain to the north, forming gallery forests and influencing, through irregular flooding events, the dynamic of the aquatic flora and fauna. The Paragua River, the Tarvo River and their tributaries are the most important routes to connect the ecoregions and sub-ecoregions (figure 15).

The forest blocks and corridors connected through streams seem to have a central join-point in the surroundings of Manomo Hill, therefore this place is of special importance for conservation in this area.

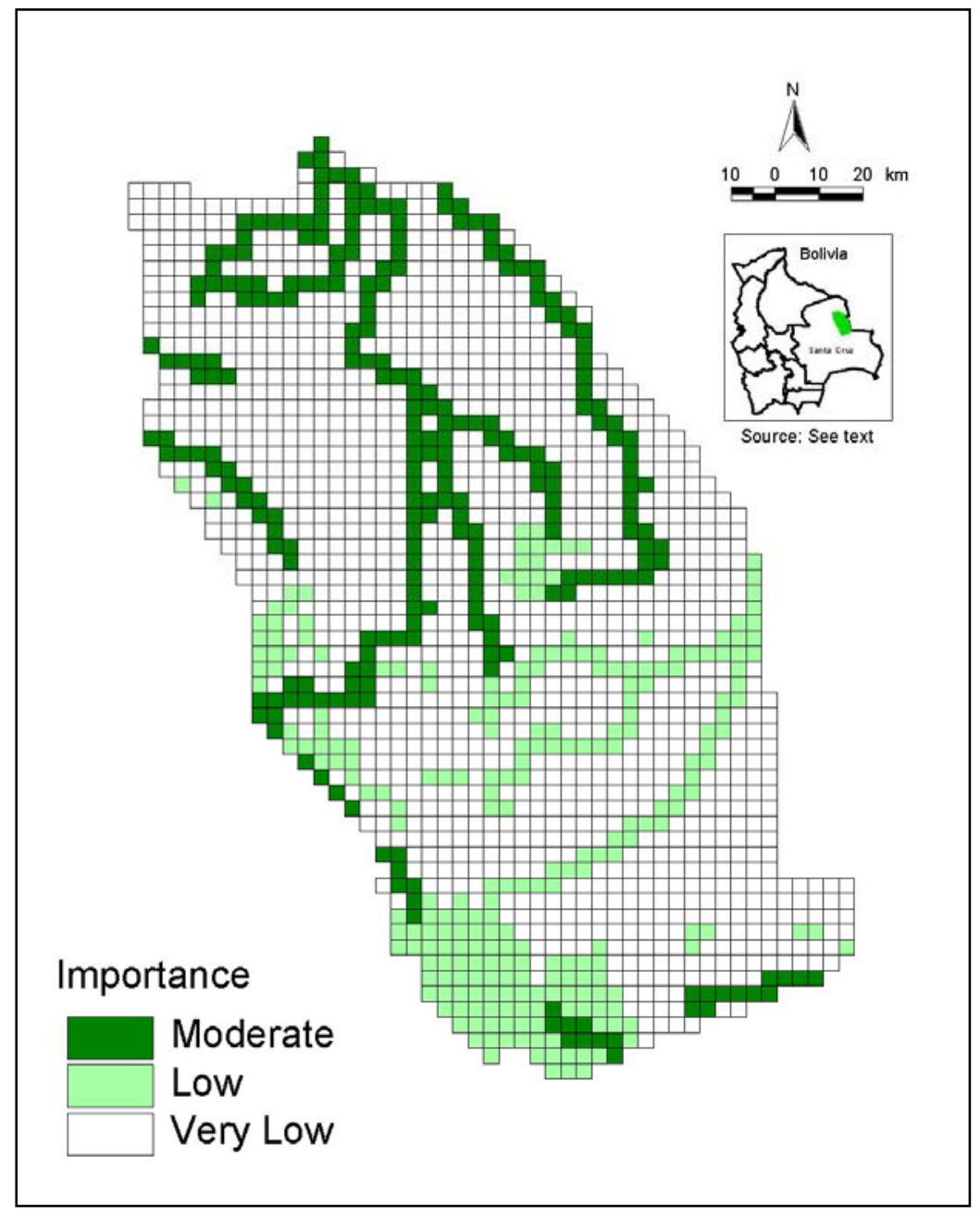

Figure 15: Valuation of areas for connectivity

\subsubsection{Biodiversity}

Being situated in the transition zone among ecoregions, the study area houses a remarkable biodiversity, which is still not studied well enough. 
Figure 16 shows the result of an estimation of biodiversity richness undertaken on the basis of vegetation and topographic data. The cells with high and very high values of diversity incidentally coincide with places that encompass several vegetation units and exhibit a deep elevation gradient. Although detailed biological studies are still needed to test this result, other researches, for instance Bates et al. (1998) and Emmons (1998), confirmed that areas with diverse vegetation have on average the highest values of total biodiversity and hills and mountains have the largest number of endemic species.

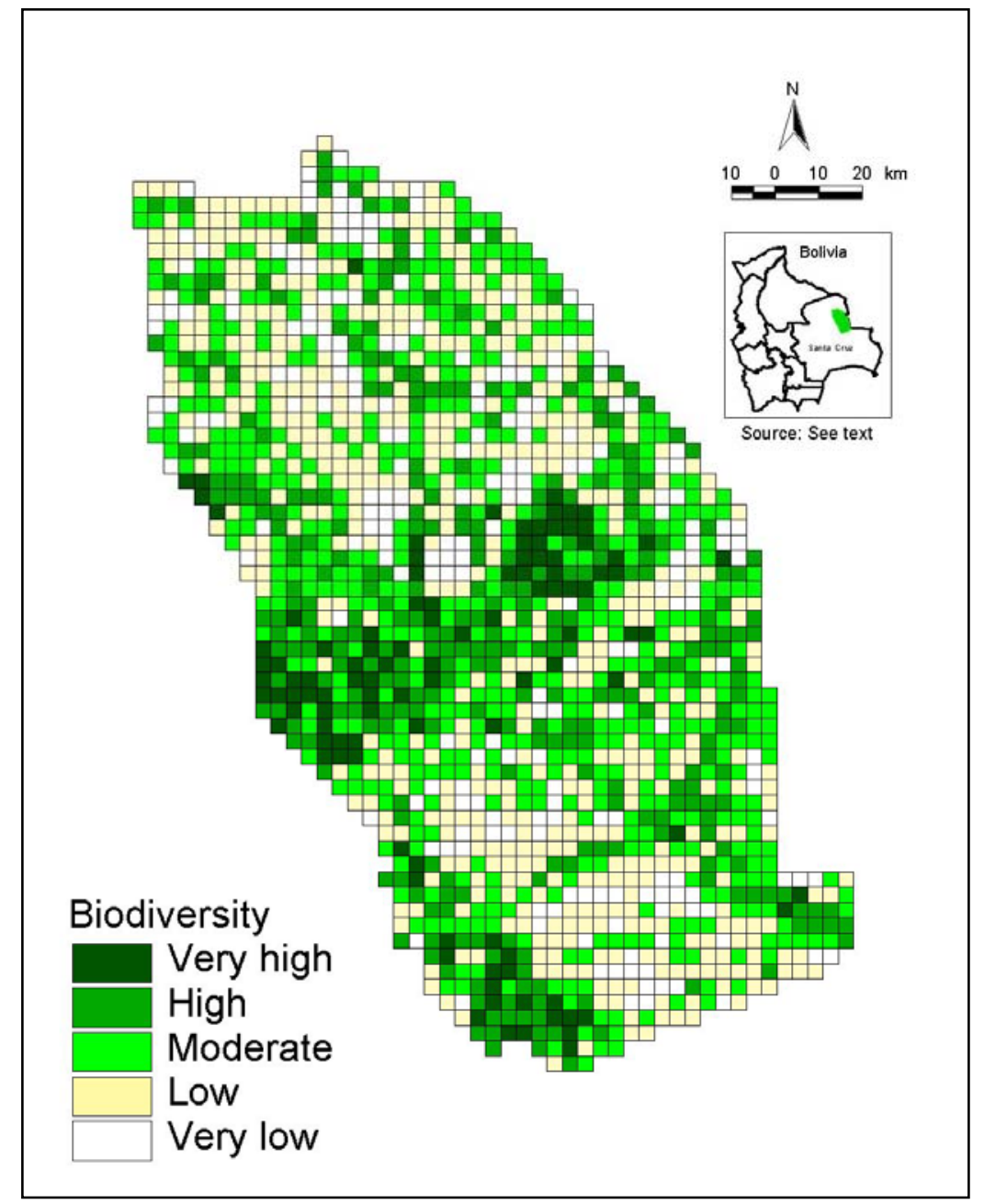

Figure 16: Estimated biological diversity

Geographically the outcome shows that biodiverse places are mainly located on two imaginary axes; one follows the direction of the Chiquitano Mountain ranges and occupies the western foothills. The second axis has a southwest to north-eastern orientation and runs from the western side of the study area up to Manomo Hill; it is almost perpendicular to the Chiquitano mountain ranges. The surroundings of Manomo Hill present the highest calculated grade of biodiversity richness; this place coincides with the transition of isohyets that indicate rainfall values between 1200 and $1400 \mathrm{~mm}$, which may mark the change of a seasonal dry 
climate to a more humid climate. According to information of the rural land office (INRA), the establishment of a protected area on Manomo Hill and their outskirts was proposed by the authorities of protected areas.

Data of biological richness from neighbouring regions and an estimation of species richness of the study zone must be mentioned in order to present an overview of diversity. It could be affirmed that the study area has an intermediate diversity between the Noel Kempff National Park in the north and the geographical action area studied by the Plan for Chiquitano Forest in the south (see annex 3 and the following tables). Nevertheless, the study area is "slightly" more similar to the Noel Kempff Park in terms of biodiversity considering that this area has the same vegetation units, except for the Pantanal Flooded Savanna.

Following estimations, the study area may host almost 3500 vascular plants, less species than the Noel Kempff Park but more than the southern area (see table 28). In the case of the fauna, taking into consideration only birds and mammals, the study area probably has fewer species of birds (estimated 500), but more species mammals (likely 200), than the Noel Kempff Park (see table 29).

Conservation activities in this intermediate place would be an important strategy to enhance the protection of biodiversity both for the Noel Kempff Park and the Chiquitano Forest. Authors like Spector (2001) agree with the statement that conservation measures in intermediate places or crossroads, like the study zone, may contribute not only to representativeness but also to the protection of evolutionary processes. 
Table 28: Registered and estimated vascular plant diversity for the study area and adjacent regions

\begin{tabular}{|c|c|c|c|c|c|}
\hline \multirow{2}{*}{$\begin{array}{l}\text { Place of } \\
\text { study }\end{array}$} & \multirow{2}{*}{$\begin{array}{l}\text { Surface } \\
\text { (ha) }\end{array}$} & \multirow{2}{*}{$\begin{array}{l}\text { Rainfall range } \\
(\mathrm{mm})\end{array}$} & \multirow[t]{2}{*}{ Ecoregions } & \multicolumn{2}{|c|}{ Number of species } \\
\hline & & & & Registered & Estimated \\
\hline $\begin{array}{l}\text { Noel Kempff } \\
\text { National } \\
\text { Park (1) }\end{array}$ & 541,200 & $1,500-1,700$ & $\begin{array}{l}\text { Amazon Forest, } \\
\text { Cerrado, } \\
\text { Chiquitano Forest, } \\
\text { Flooded Savanna }\end{array}$ & 2,700 & 4,000 \\
\hline $\begin{array}{l}\text { Study Area } \\
\text { (2) }\end{array}$ & 600,000 & $1,000-1,500$ & $\begin{array}{l}\text { Amazon Forest, } \\
\text { Amazon Flooded } \\
\text { Savannas, Cerrado, } \\
\text { Chiquitano Forest, } \\
\text { Pantanal Flooded } \\
\text { savanna. }\end{array}$ & No data & 3,500 \\
\hline $\begin{array}{l}\text { Geographical } \\
\text { action area } \\
\text { of FCBC (3) }\end{array}$ & $7,700,000$ & $1,000-1,300$ & $\begin{array}{l}\text { Chiquitano Forest, } \\
\text { Cerrado, Pantanal } \\
\text { Flooded Savanna } \\
\text { and Chaco }\end{array}$ & 823 & 3,500 \\
\hline
\end{tabular}

Sources: (1) Management Plan of Noel Kempff National Park, FAN \& TNC (1997), (2) Gathered data of the project POP and RPPN, Natural History Museum of Rene Moreno University, (3) Conservation and Sustainable Plan for the Chiquitano Dry Forest, Cerrado and the Bolivian Pantanal (PCDS), Ibisch et al. (2002).

Table 29: Diversity of birds and mammals of the study area and adjacent areas

\begin{tabular}{|l|l|l|l|l|c|c|}
\hline Place of & \multirow{2}{*}{$\begin{array}{l}\text { Surface } \\
\text { study }\end{array}$} & $\begin{array}{l}\text { Rainfall } \\
\text { (ha) }\end{array}$ & Ecoregions & \multicolumn{2}{|c|}{ Quantity } \\
\cline { 4 - 7 } & range & Birds & Mammals & $\begin{array}{l}\text { Amphi- } \\
\text { bians }\end{array}$ \\
\hline $\begin{array}{l}\text { Noel Kempff } \\
\text { National } \\
\text { Park (1) }\end{array}$ & 541,200 & $1,500-1,700$ & $\begin{array}{l}\text { Amazon Forest, } \\
\text { Cerrado, } \\
\text { Chiquitano Forest, } \\
\text { Flooded Savanna }\end{array}$ & 617 & 139 & 62 \\
\hline $\begin{array}{l}\text { Study Area } \\
(2)\end{array}$ & 600,000 & $1,000-1,500$ & $\begin{array}{l}\text { Amazon Forest, } \\
\text { Amazon Flooded } \\
\text { Savannas, } \\
\text { Cerrado, } \\
\text { Chiquitano Forest, } \\
\text { Pantanal Flooded } \\
\text { savanna.. }\end{array}$ & $\begin{array}{c}327 \\
\text { (expec- } \\
\text { ted } \\
\text { almost } \\
500)\end{array}$ & $\begin{array}{c}66 \\
\text { (expected } \\
\text { almost 200) }\end{array}$ & No data \\
\hline $\begin{array}{l}\text { Geographical } \\
\text { action area } \\
\text { of FCBC (3) }\end{array}$ & $7,700,000$ & $1,000-1,300$ & $\begin{array}{l}\text { Chiquitano Forest, } \\
\text { Cerrado, Pantanal } \\
\text { Flooded Savanna } \\
\text { and Chaco }\end{array}$ & 575 & 533 & 144 \\
\hline
\end{tabular}

Sources: (1) Management Plan of Noel Kempff National Park, FAN \& TNC (1997), (2) Gathered data of the project POP and RPPN, Natural History Museum of Rene Moreno University, (3) Conservation and Sustainable Plan for the Chiquitano Dry Forest, Cerrado and the Bolivian Pantanal (PCDS), Ibisch et al. 


\subsubsection{Headwater protection}

The study area plays an important role in regulating the water behaviour both at local and at macro-regional level. The main rivers, streams and headwaters can be seen in figure 17 .

At local level, that is within the region, the continuous forest cover allows a stable water flow both in the rainy and the dry season. Signs of heavy erosion, like red water or large sediment depositions, are not observed in the lower parts of this region.

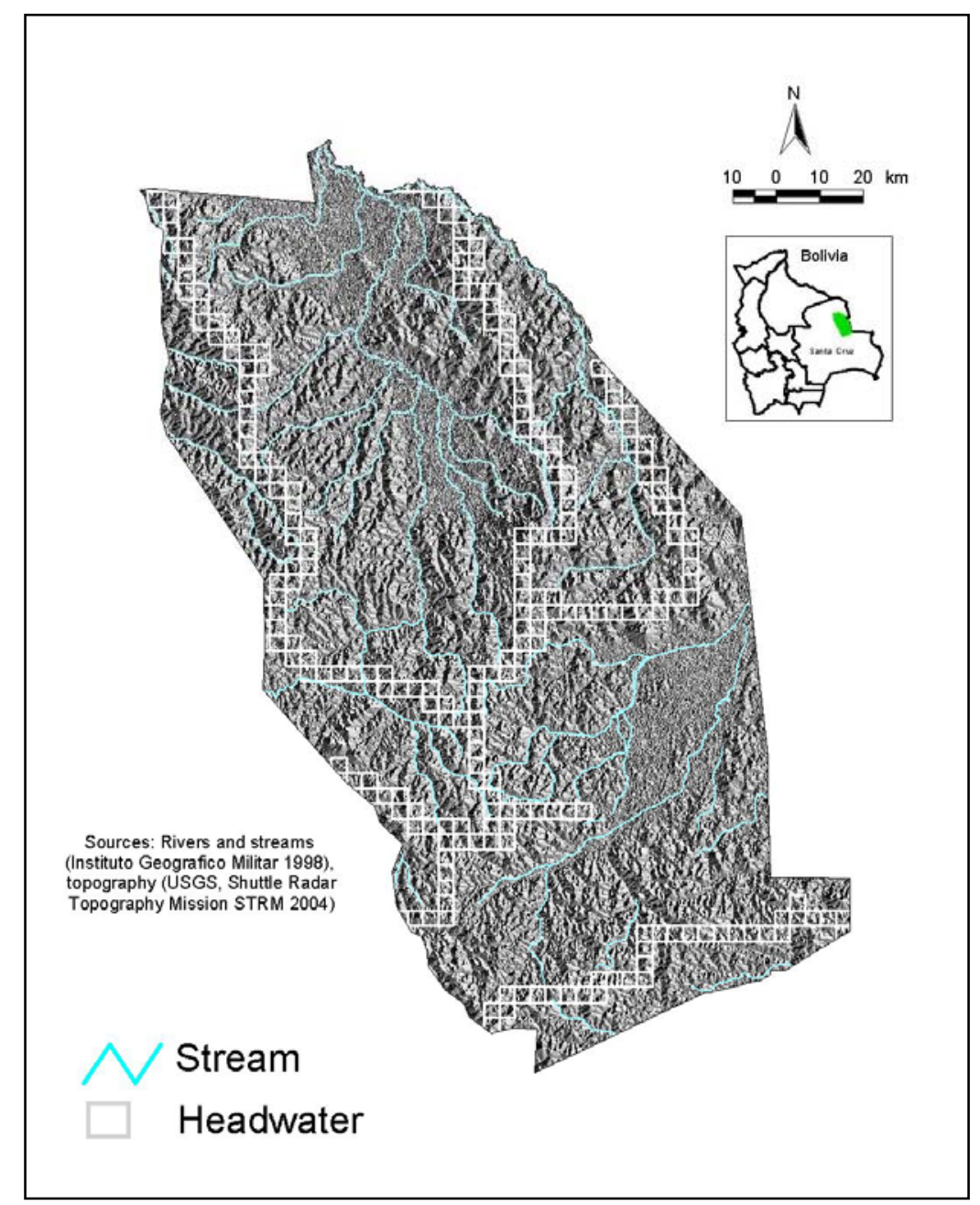

Figure 17: Headwaters of the study area

The water dynamic determines seasonal flooding that is an important natural phenomenon for aquatic and amphibian species not only for the study area but also for the areas close to Noel Kempff National Park.

The maintenance of a stable flow of the rivers also has an economic and a social importance for the communities living in the surroundings of the Paragua and the Tarvo River as these people obtain a vital source of food from fishing. In 2003, seasonal fish-death was reported 
and the communities have called for the avoidance of fire-practices that could have caused this death.

On the macro scale, the study area is a part of the large headwaters of the Itenez or Guapore River, which encompasses the Mato Grosso Mountain Range, the foothills of these mountains and the flooded savannas. The stabilisation function of the whole area is similar to what the Pantanal areas do to the Paraguay River.

\subsubsection{Integrated biological-ecological value}

The above separately analysed topics show the biological and ecological worth of the study area. To achieve an image of the conservation necessities an integrated valuation was undertaken through the use of geographical information systems.

The outcome of this operation, printed in figure 18, establishes that areas with a high value for conservation are located near the Manomo Hill, the area in the north of the "Carmen de Ruiz" community and on the riverbanks of the Tarvo river. Areas covered with forest received a moderate valuation.

The open flooded areas (both the Amazon and Pantanal Savannas) were marked with lower values. The results seem to show that an imaginary vertical band - which runs from the south to the north crossing the Manomo Hills - marks the area that would allow the protection of the main biological values, environmental services (basin protection and climate-stabilization) and especially the connectivity.

The function of connectivity should be highlighted in this integral bio-ecological valuation, because it was one of the main reasons to undertake this study. The global climate changes that are threatening the biodiversity (Thomas et al. 2004) urge to consider not only representativeness as main requirement for conservation, but also functionality (Ibisch \& Araujo 2004). The Chiquitano Forest occupies a semi-arid environment in conditions of gradually raising temperatures; the elements of this ecoregion will suffer difficulties (hydro stress for example) and they will need escape-areas, in this specific case towards more humid areas located in north. The conservation of a large isolated area of this ecosystem will not be enough to guarantee this forest, hence its connections to the north must be guaranteed.

Under those circumstances the conservation of a natural belt crossing the area and following the above mentioned band has a high priority in order to contribute to a long-term maintenance of this unique environment. 


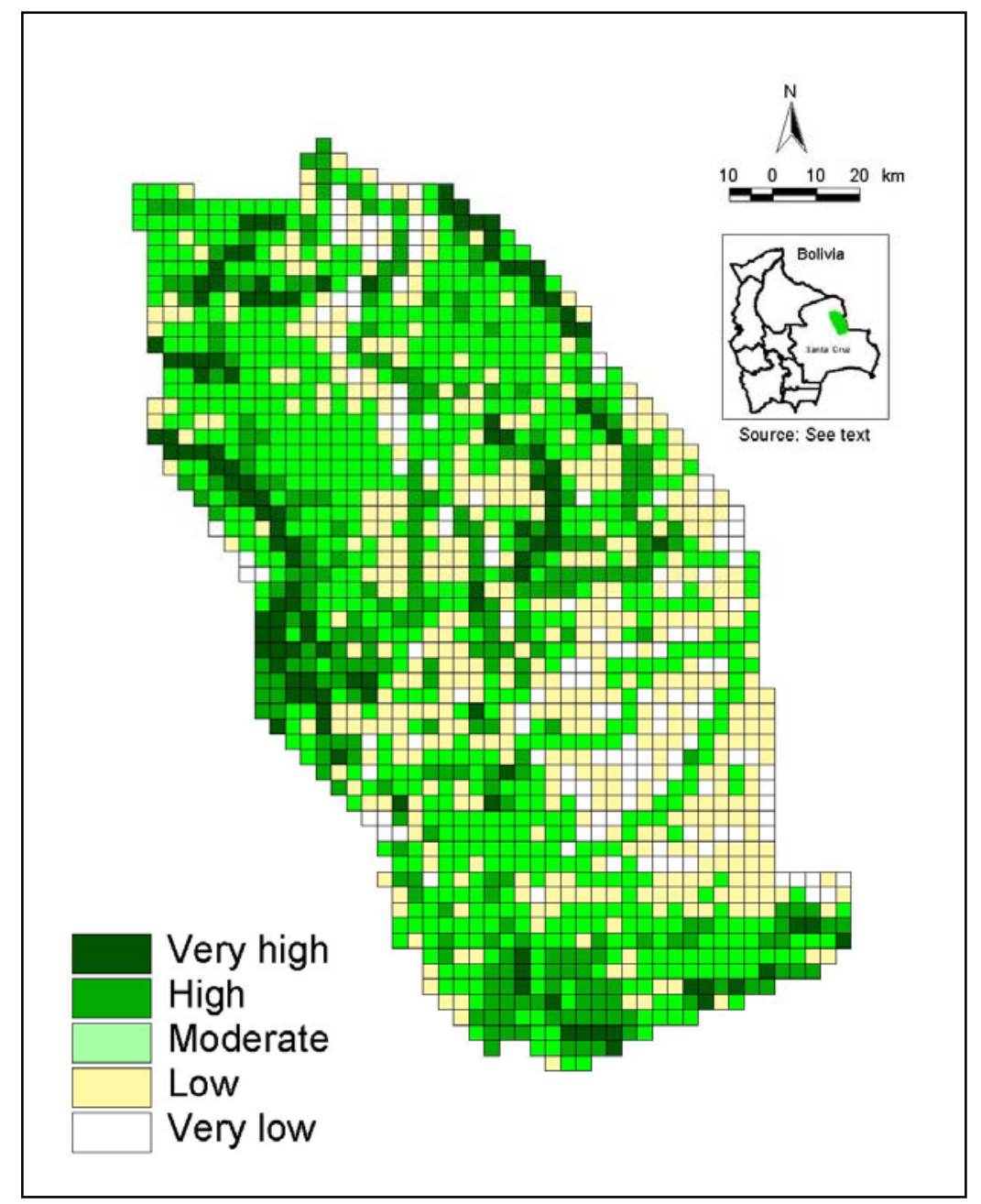

Figure 18: Integrated biological-ecological value

\subsubsection{Impact of human activities and status of conservation}

In this chapter, the human influence on natural areas of the study zone is valuated in order to assess real possibilities for conservation activities. The impact of human activities in this zone is regarded with reference to locations of population centres, road infrastructure, agriculture and livestock production and logging.

\subsubsection{Impact due to population centres}

Population centres (cities, towns and communities) indicate an impact on biodiversity, mainly due to hunting, firewood harvesting and pollution. Analysing the geographic classification of the population-density it can be observed that in general, the area of study still suffers a relatively low human impact (see figure 19).

The capital of the municipality San Ignacio, a little town, is the largest population-centre in the study zone; it has 19,401 inhabitants (INE 2004) and therefore presents the highest 
calculated impact according to the estimation of human influence, shown in figure 19. San Ignacio is the economic centre of the whole region as well as the main receptor of migrants within this municipality. The other towns and communities have comparatively low rates of population density and consequently less impact on biodiversity.

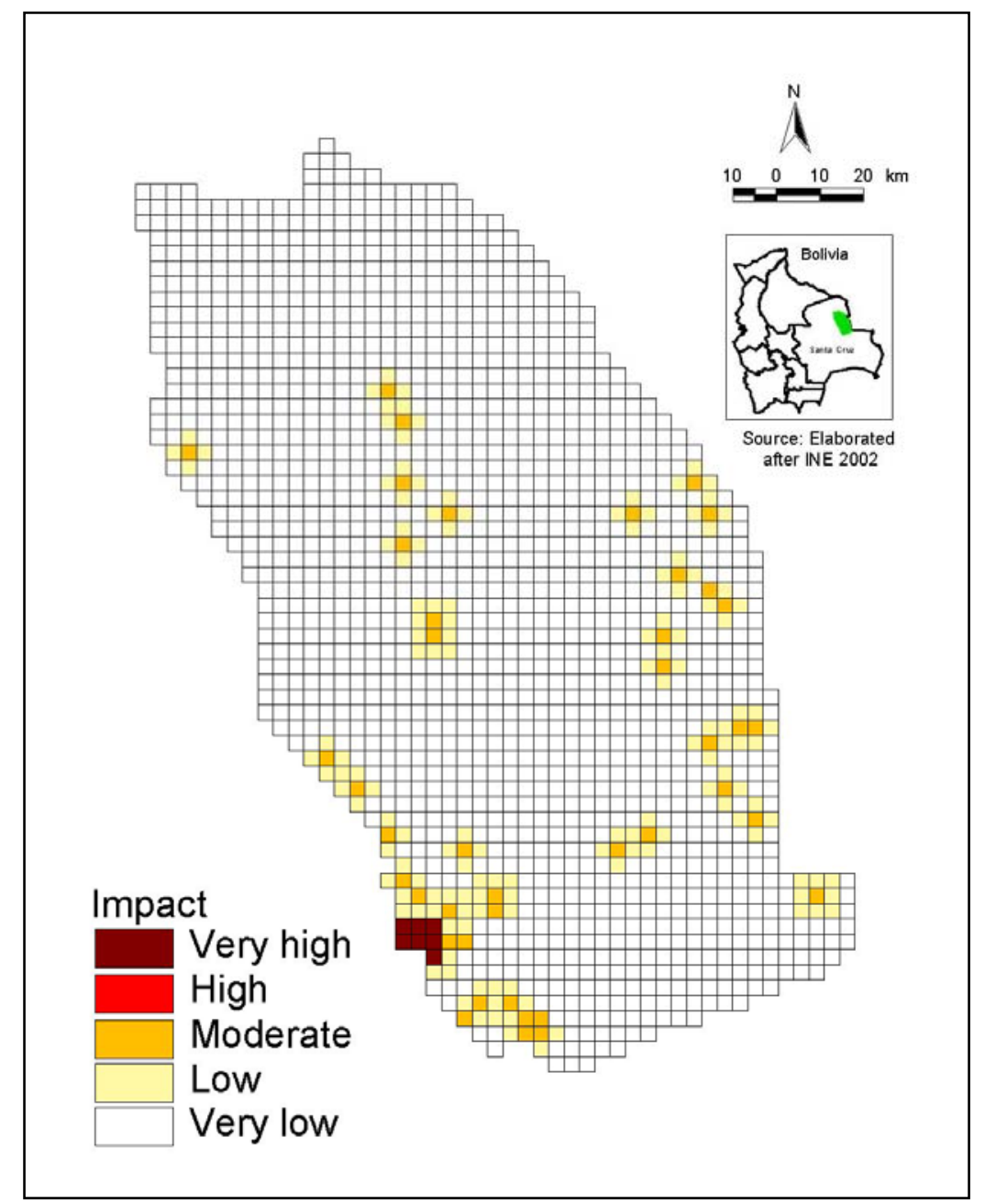

Figure 19: Grade of impact on biodiversity due to population centres

The population of the whole municipality grew by $2.92 \%$ from 1992 to 2001 (INE, 2002). This indicates a low trend of population-growth in comparison to other municipalities of Santa Cruz. However, new economic tendencies, like international road integration, may cause an increase in population in the next years, which might be harmful for biodiversity if regional planning measures are not carried out carefully.

Almost $75 \%$ of the population in the study area are indigenous people. The indigenous population is called "Chiquitanos", and they are descendants of populations settled in the lowlands before the Spanish Conquest. Their communities have been transformed, restructured and reduced by the Spanish conquerors. Their economies were incorporated 
mainly into the production of introduced products and in some cases also cattle farming (Calvo, 2004). These people live today mainly in poverty and have problems with land property rights. An integral conservation strategy should take this group into consideration, not only as a potentially important group that could affect the natural resources but mainly as a group that may contribute to conservation.

\subsubsection{Impact of roads}

Roads are one of the main indicators of human impact on biodiversity in the study area, and in general in the majority of Bolivian rural zones (Steininger et al. 2001, Ibisch 2004, Nowicki 2004). As one might expect, the location of roads determines the location of towns and community dwellings, as is shown in figure 20 .

For the study-zone, four categories of roads could be mentioned: (1) internationaldepartmental roads, (2) inter-provincial roads, (3) interregional roads and (4) local roads (see methodology), which can be seen in figure 20 . None of these roads is made of asphalt and only the first category ensures permanent transit.

The assessment of the influence of roads on biological diversity, displayed in figure 21 , indicates that the impact is still low due to the slow development of these infrastructures. The grade of human impact is correlated with the road category, thus international-departmental ones show the highest grade of negative influence on wildlife (for instance due to deforestation) in comparison to regional and local roads.

It must be underlined that the construction of the main road in the study area between San Ignacio and San Matias has had a negative effect because it started the process of fragmentation of the Chiquitano Forest in this region. Currently there still exist places along this road where the Chiquitano forest has not been cleared; nevertheless, observed trends tend to an intensive future land use near this road. Both Bolivian and Brazilian Governments seem to be interested in the improvement of this road allowing the establishment of a bi-oceanic route to promote economic integration. This fact has promoted movements of investments reflected in the attempts of land purchases by Brazilian individuals and enterprises.

The other roads show less tendencies of harmful effects on biodiversity. One that seems to be relevant is the inter-provincial road "Santa Rosa de la Roca-Florida", located in the west, where colonists once established their first settlement, but these colonist have been stopped due to the opposition of the local people of this region. 


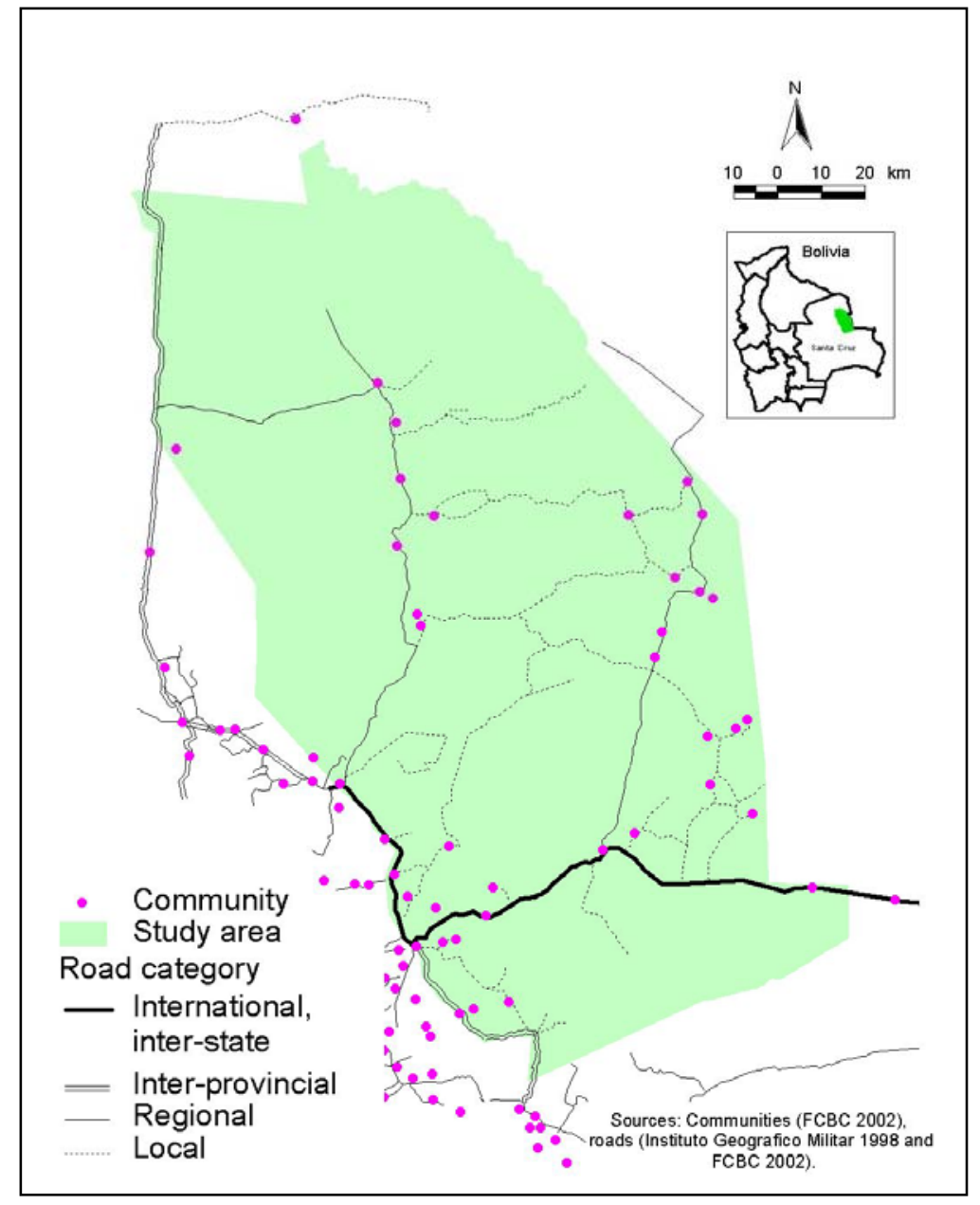

Figure 20: Roads and human centres in the study zone

Although infrastructural projects in general means a great opportunity for economic development, collateral consequences should be determined to prevent negative effects in particular for the Chiquitano forest. The maintenance of a sustainable basis for economic activities should be of prime importance. Intensive deforestation, for instance, would break the soft equilibrium of the humid cycle and as a consequence affect the whole agricultural and livestock system. This phenomenon can already be observed in the forests with similar features near Santa Cruz (Bounoua et al. 2003). 


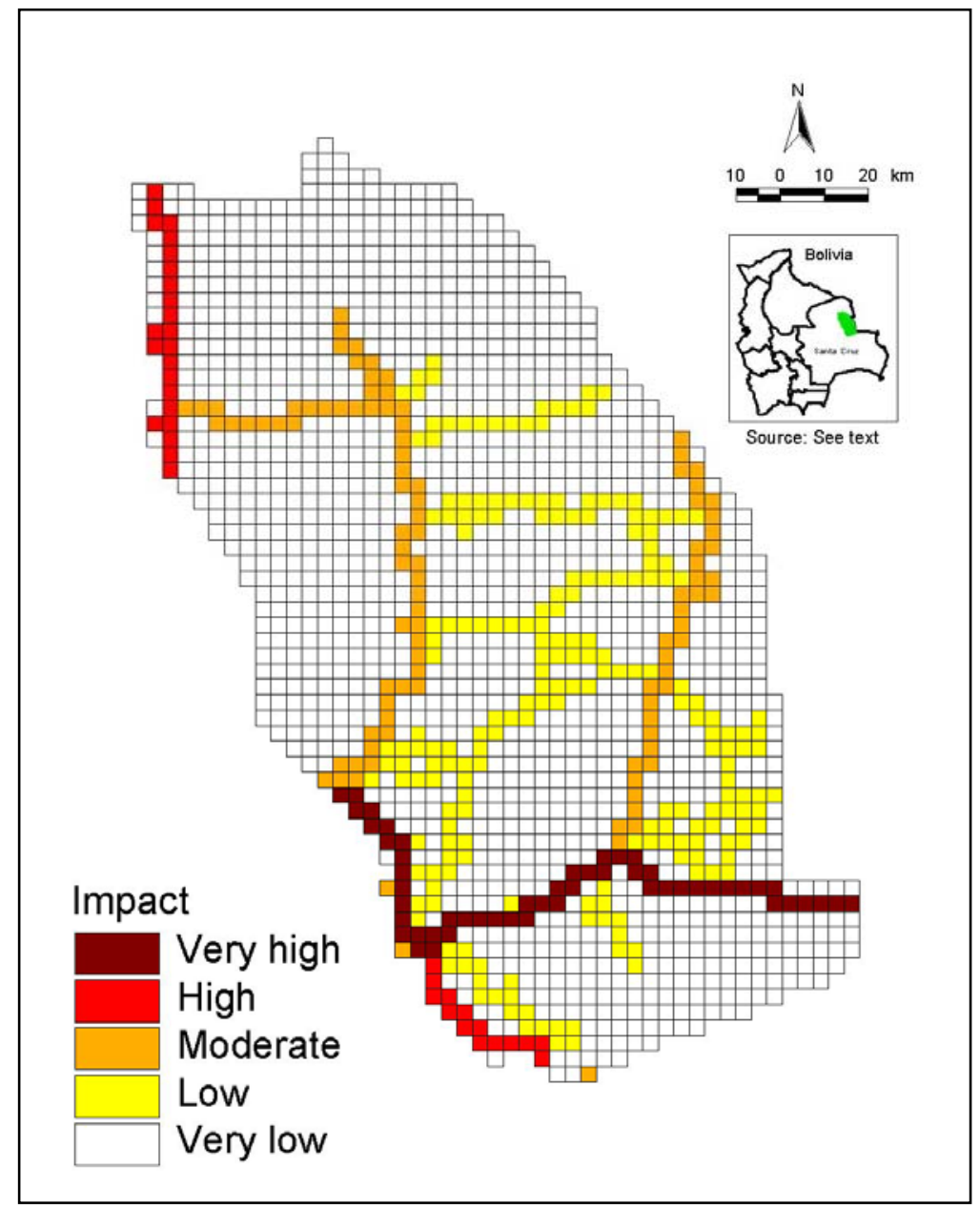

Figure 21: Estimated impact on biodiversity due to roads

\subsubsection{Impact due to deforestation and land use}

The most severe human impact on biodiversity in the study-zone has occurred through the expansion of the agricultural frontier due to the conversion of natural areas into pastures and cropland as well as due to the use of natural open areas for cattle ranching.

Deforestation processes have affected areas along the main roads. Satellite imagery observations (2000 and 2003) showed that these processes are at the early stage. In average, the cleared areas occur within a 1-km buffer along both the international-departmental road of San Ignacio-San Matias and the interregional road between Carmen de Ruiz and Florida (see figure 22).

The largest deforested areas were opened for ample cattle ranches mainly located in the ecoregion of the Chiquitano forest, which has better soil properties, to develop extensive livestock. In addition, community-lands conduct deforestation but it is not as significant as in the other case because the purpose of the deforestation is small-scale farming. 
The impact due to the use of open areas for ranching, less visible through remote sensors, has affected the biodiversity of the study area for decades. It occurs on large ownerships as well as on small community lands. Few open areas were converted into pastures because of the poor conditions of the soil and flooding in the rainy season.

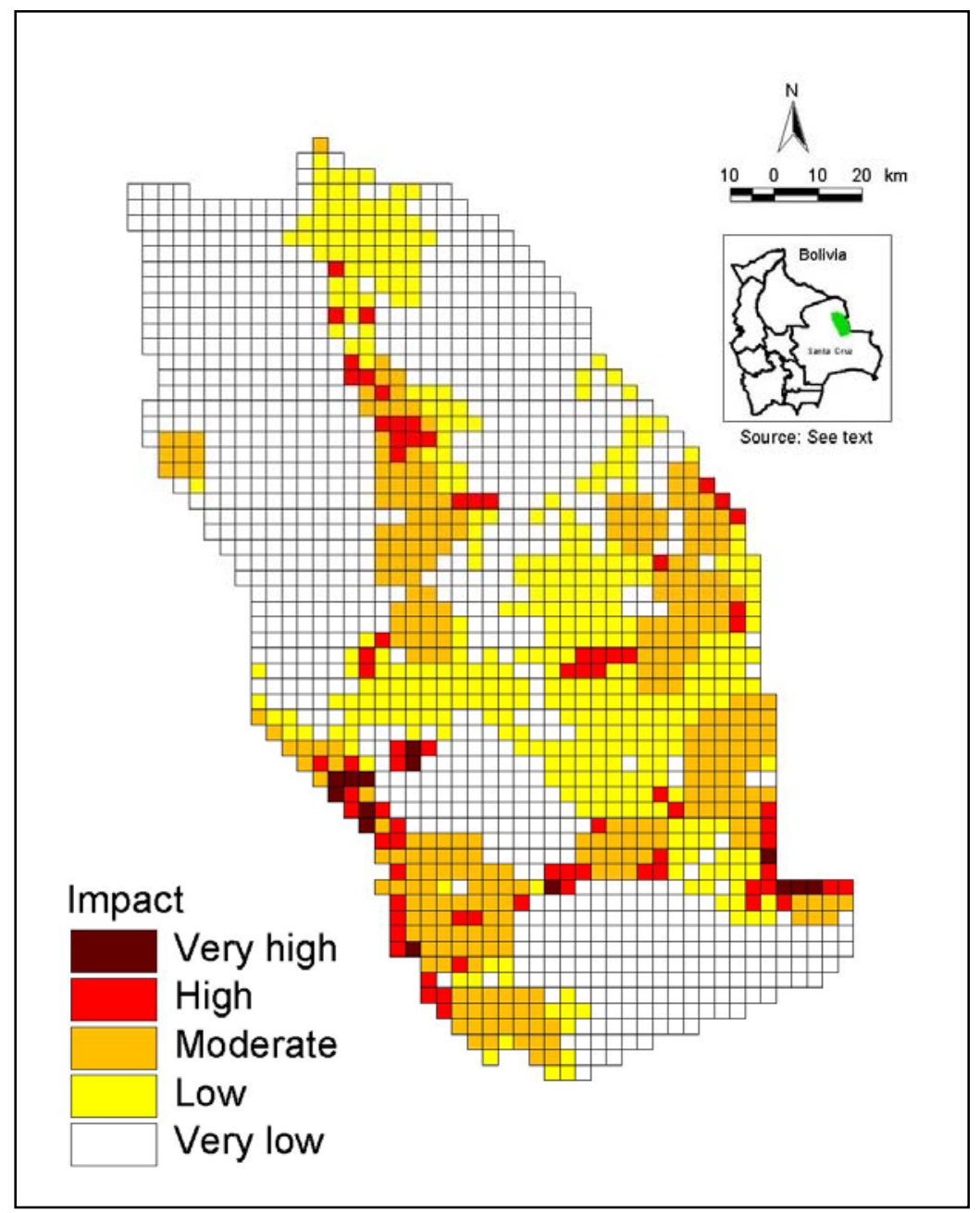

Figure 22: Estimated impact due to deforestation and land use

To conclude this point, it must be remarked that the first stage of deforestation has already been undertaken in the zone, according to the assessment shown in figure 22 . Therefore now would be the best point in time to enhance conservation activities with the stakeholders of the region in order to protect the natural values. Many authors such as Steininger et al. (2001), Cordona (2003) and Millington et al. (2002), who studied the deforestation process, have established the importance of planning and mitigation measures in these early stages in order to avoid the fragmentation and destruction of sensitive ecosystems. 


\subsubsection{Impact due to forest activities}

Most of the study zone has been classified as zone for forestry use by the departmental land use plan, because of the soil, climate and socio-economic conditions (Prefectura del departamento de Santa Cruz 1996; Ibisch et al. 2002). As mentioned in 5.1.2.1, the forest cover is still very large, but some forest areas have undergone a selective extraction and, as a consequence, their economic value was affected.

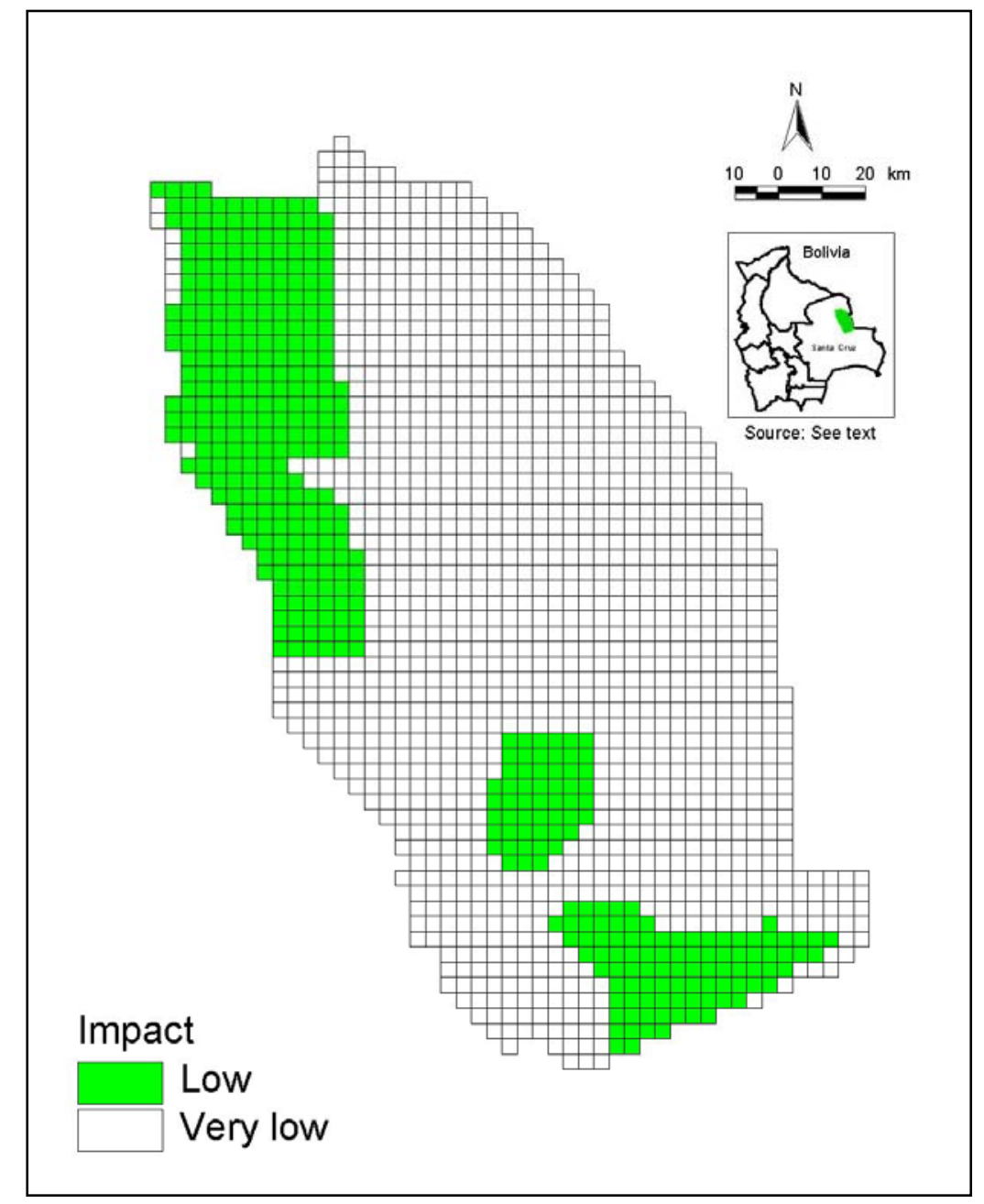

Figure 23: Impact due to forest activities

Within the study-zone, municipal forest areas have been conceded to small-scale-loggers in order to promote the sustainable use of the forest resources, avoiding illegal logging and stopping settlement attempts. During the carrying out of this study, little forest activities were undertaken in those forest areas, because the loggers were preparing their management-plans, but there existed information that illegal extraction of wood was being done there. In addition, both large-cattle-ranch owners and communities have used and are still using the forest resources - only in very few cases with logging-plans. 
The impact of planed logging on biodiversity is considered to have the lowest effect among other production activities (Fredericksen 2004), for this reason, in this study, municipal-forest areas received a low valuation of impact, as can be seen in figure 23. However, it should be recognised that illegal forest activities were underestimated.

The promotion of sustainable forestry is one of the best strategies to use and conserve at the same time forest ecosystems. However, there are a lot of constraints, especially the fact that the benefit of this activity will be obtained in the long term only and nowadays the loggers want to maximize their short-term profits (Pacheco 2001).

\subsubsection{Conservation status}

The integral consideration of the mentioned socio-economic variables allows to obtain a general view of the degree of human intervention in the study area. The map shown in figure 24 reflects the estimation of the conservation status and leads to important conclusions how to determine areas with better conservation chances considering the human population.

The results indicate that $69 \%$ of the area has a very good status, this corresponds to the ecosystems with primary and mature forest that in some cases were exploited but likely without harming the original population (Ibisch et al. 2004). Open areas also take part in these areas, especially those that are far away from human centres.

Areas with a good conservation status (17\%) represent places that maintain their natural properties but have a certain human impact, in particular through cattle ranching.

Areas with a downgraded conservation status (regular, critical and very critical) cover only $14 \%$ of the study-area.

The results of the characterisation of the conservation status almost coincide with the general estimation of the conservation situation in Bolivia undertaken by Ibisch et al. (2004). The mentioned study describes the study area as a zone in a "good" conservation status. The reason for this difference could be explained because of work scale.

The analysis of the conservation status of the study area shows a very positive scenario for conservation activities and should therefore enhance the investments in nature protection. 


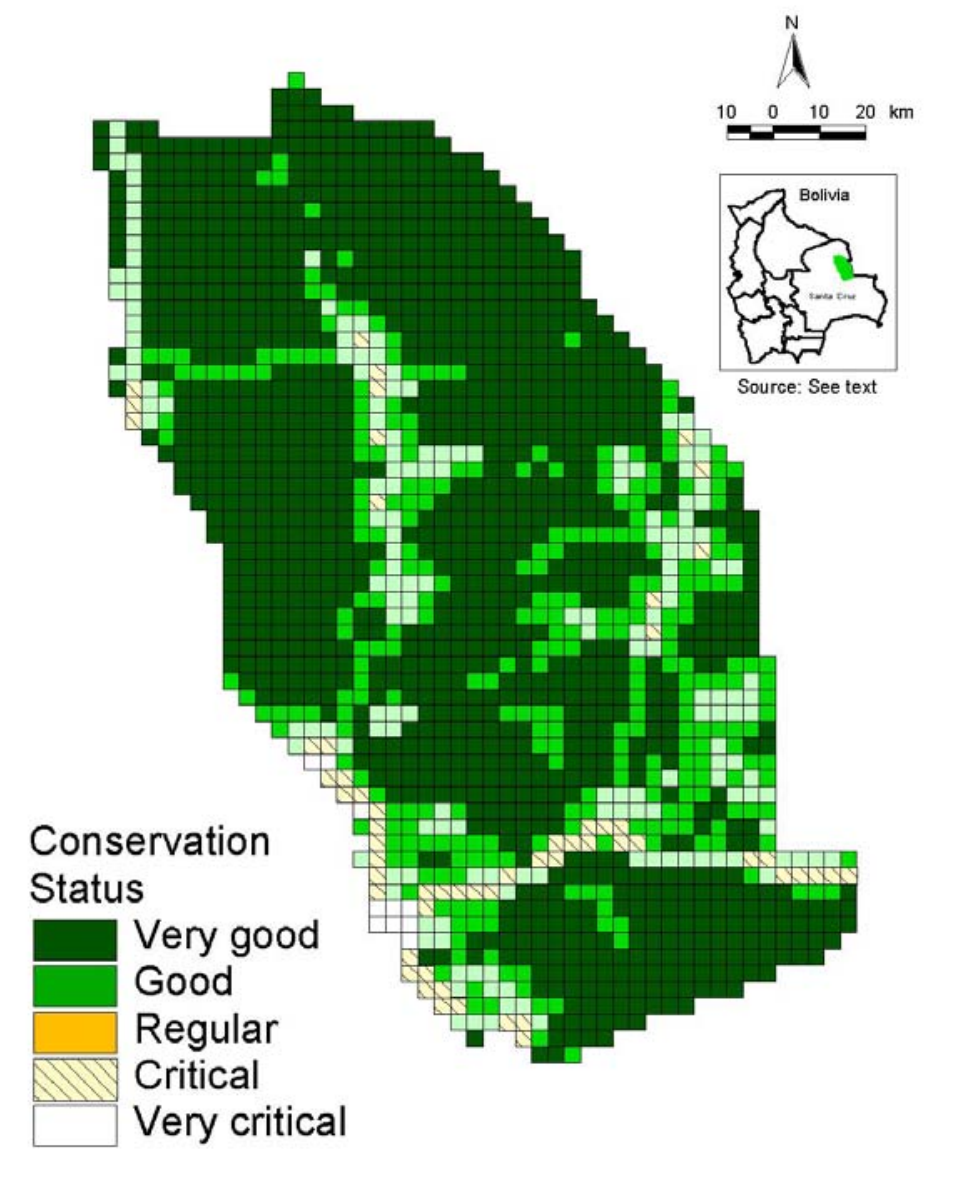

Figure 24: Map of the conservation status of the ecosystems

\subsubsection{Land tenure and regulatory dispositions}

A comprehensive analysis of the conditions of biodiversity conservation in the study area would not be complete if land tenure and regulatory dispositions were not taken into consideration. The land tenure situation is a main factor that determines participation of landowners in biodiversity conservation.

Past and relevant studies about conservation planning (Ibisch et al. 2000, Araujo \& Ibisch 2000, Ibisch et al. 2002); which contributed data and the methodological basis for this study, faced several difficulties to gain a detailed description of the rural property situation. Little feasible data of land property and the reliability of them have been the main reasons. A similar situation occurred in this study, however, given the geographic small dimension of the study, the gathering of property data was less complicated and although the gathered data is not complete, a better approximation of the real land tenure situation was reached than in the former studies. 
In the study area, three property types were identified: forest and protected municipal areas, community lands and large private landholdings. In the following paragraphs a description of the three land type categories with regard to conservation issues is given.

\subsubsection{Forest and municipal protected area}

Six large plots of municipal public areas were registered; these are fiscal lands and belong to the municipality. Five of them have been conceded to local organisations for supervised logging and the sixth plot has been declared as municipal protected area (see figure 25).

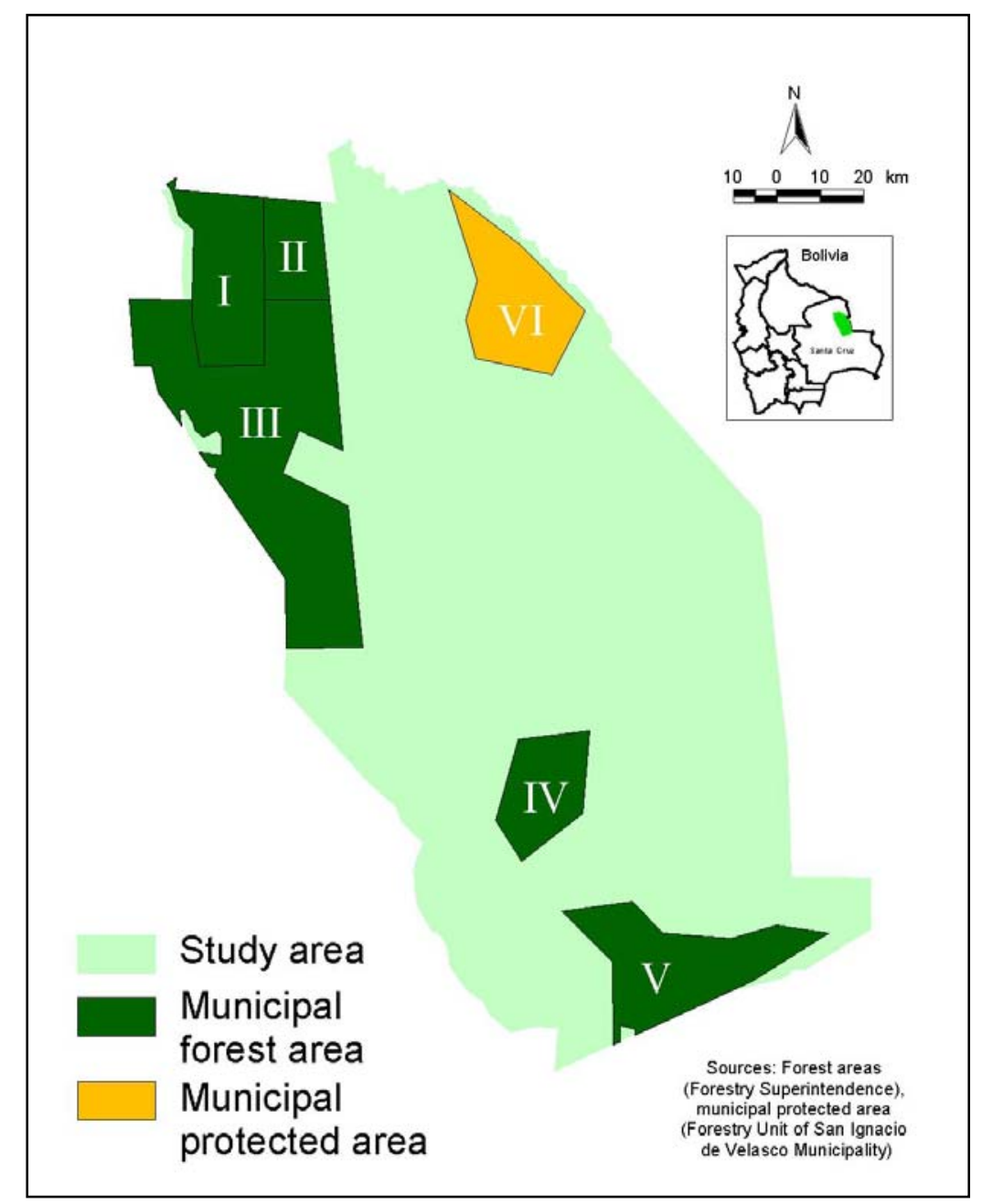

Figure 25: Location of municipal forest areas and the municipal protected area

The five forest plots and the municipal protected area together cover $25.8 \%(527,567.82 \mathrm{ha})$ of the whole studied surface. According to the ecoregional analysis, $91 \%$ of this area has a very good conservation status and $37 \%$ of the areas with high biological and ecological value are within these plots (see figure 26). Both parameters underline the importance of those areas for whatever process of conservation. 
Furthermore, the location of these areas is augmenting their value; three forest plots (marked as I, II and III) are placed abreast, and thus covering together a large surface that is significant to maintain species' habitats, especially if sustainable logging is carried out.

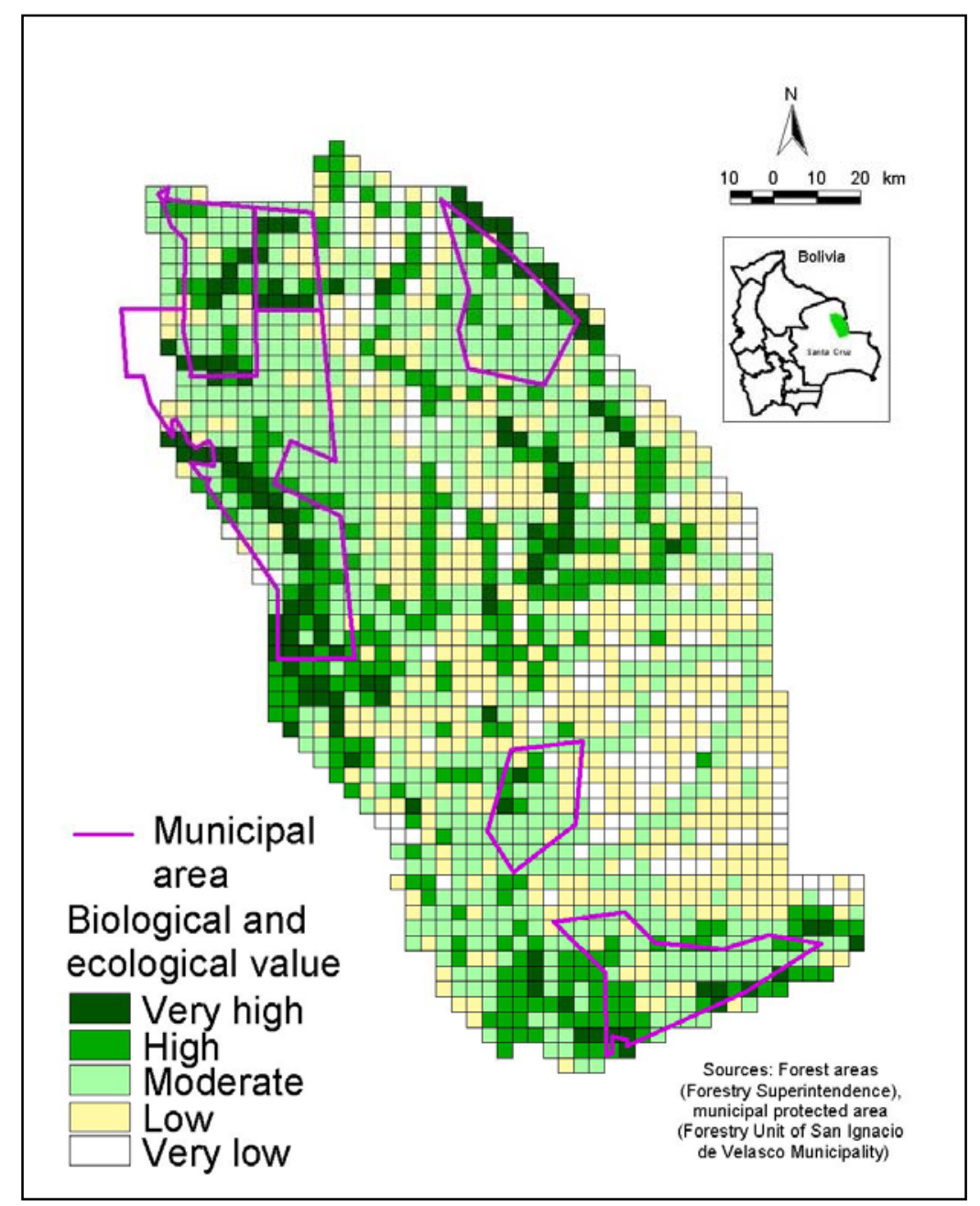

Figure 26: Comparison of the forest areas with the municipal protected area regarding the bioecological valuation of the study area

The other forest plots (IV and V) lie relatively close to each other, but are separated by the international and interstate road San Ignacio-San Matias. The area between those forest areas is still under an almost continuous forest cover with a low grade of conversion, thus if conservation reserves are established in this place, a large conservation block will mitigate forest fragmentation.

The municipal protected area is far away from the large forest plots, however, as it is located near Noel Kempff National Park it contributes to the increase of the conservation area in this region. It is known that the establishment of this municipal protected area was not only for conservation purposes but had also the aim to ensure and delimit public lands. Consequently, the potential development of this area remains uncertain because of the lack of economical 
sources to finance protection and management as well as the fact that the municipality of San Ignacio has already $31 \%$ of its surface under protection.

Due to the process of land tenure regularisation undertaken by the Bolivian Government, the limits both of the forest and the protected areas are being revised. During the realisation of this study, overlaps between public areas and private areas has been reported to lead to land conflicts. It could be estimated that the surface of forest and municipal protected areas will probably shrink due to social pressure. However, the value of these public areas for a general conservation strategy is very high and the policy makers and policy-enforcers should take this fact into consideration.

\subsubsection{Community lands}

As mentioned, the Chiquitanos are the main ethnological group in the study zone. These populations normally have their dwelling-centres located near the roads in small settlements (see figure 27).

Territories of 22 communities have been registered; they cover $4.5 \%(95,973.92 \mathrm{ha})$ of the whole study area. Furthermore, there exist 18 communities, whose lands have not yet been inventoried (see table 30). According to this data, it is estimated that these communities own approximately a further $8 \%$ of the total study area.

Most of the community lands have a critical or very critical conservation status due to forest clearing and hunting, nevertheless, it has been established that strong deforestation processes have not occurred in community lands (figure 28).

In the past years, the communities of the zone have demonstrated an eager interest in land use planning and conservation of the natural ecosystems, mainly, because these instruments could be used as tools to consolidate land property. Local NGOs, for instance "MINGA", are supporting the land titling and also planning processes. 


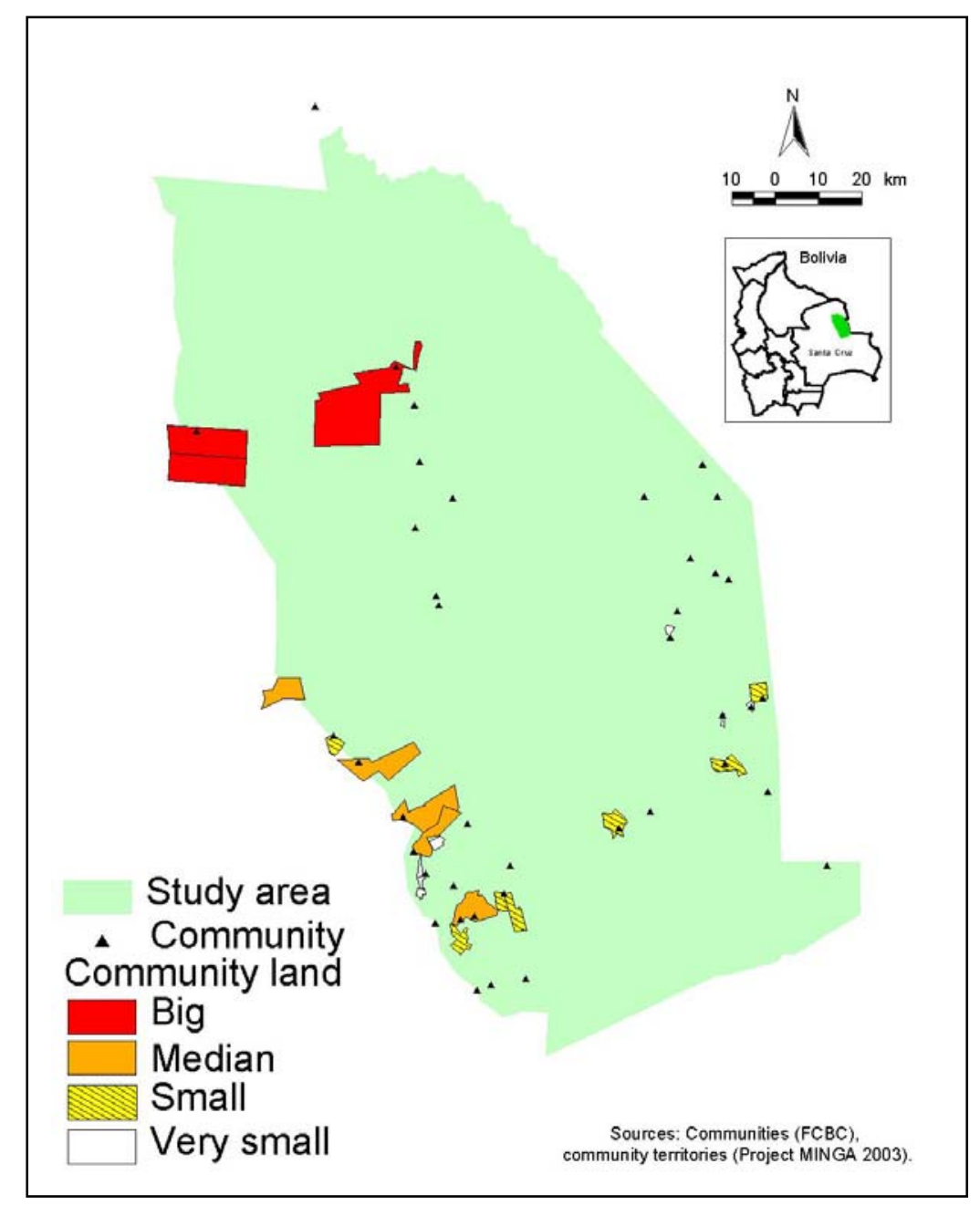

Figure 27: Registered community land and its categorisation

Table 30: Statistical data of community lands

\begin{tabular}{|l|l|}
\hline Total registered area & $95,973.92$ ha \\
\hline Number of registered communities & 22 \\
\hline Total number of communities & 40 \\
\hline Average size of community land & 4.362 .45 ha \\
\hline Largest registered community & 27.524 .83 ha \\
\hline Smallest registered community & 216.85 ha \\
\hline Land size categories (ha) & $\begin{array}{ll}\text { Big: } \quad>8,000 \\
\text { Regular: } 2,501-8,000 \\
\text { Small: } \quad 700-2,500 \\
\text { Very small: }<700\end{array}$ \\
\hline
\end{tabular}




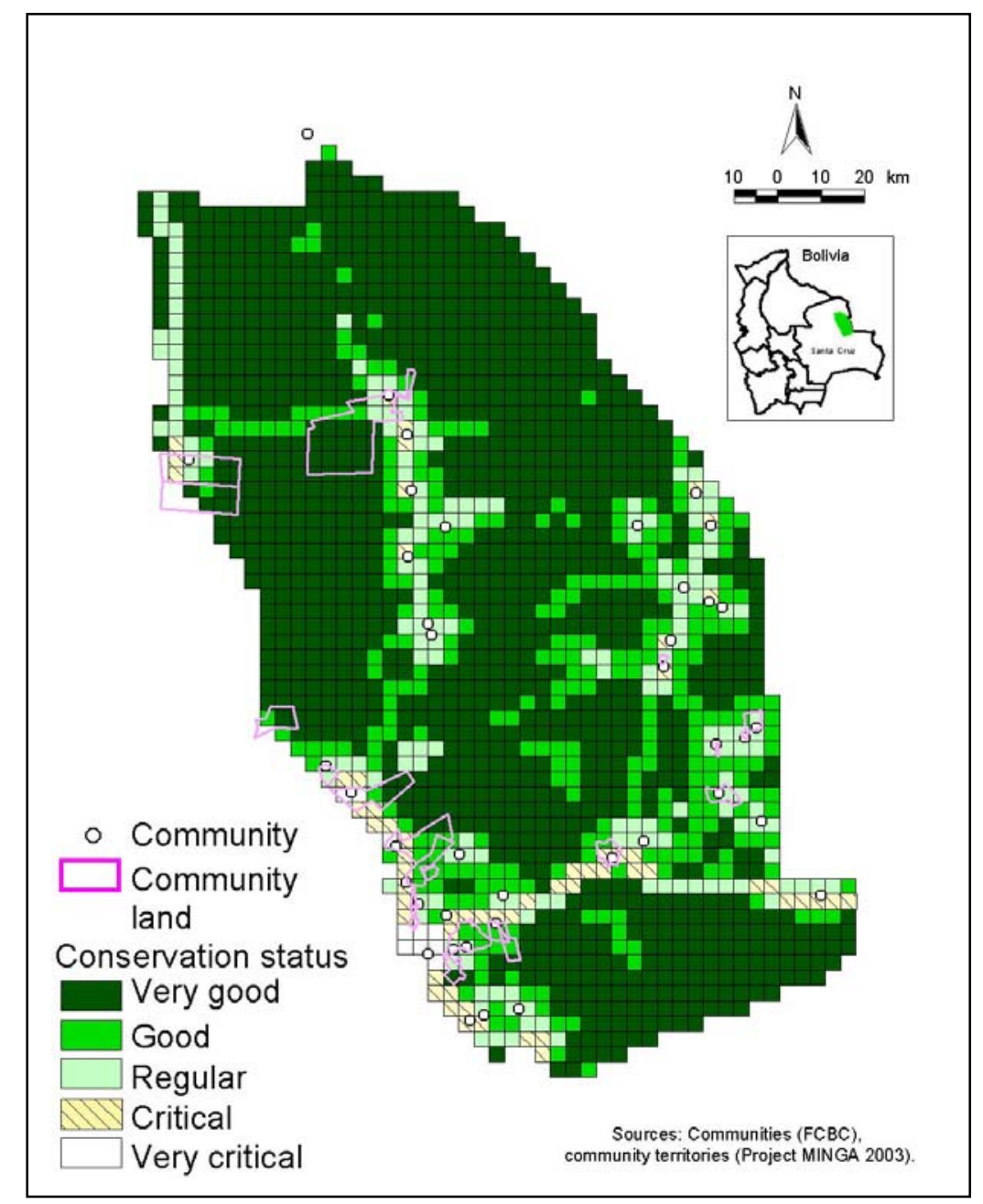

Figure 28: The location of community land in the study zone and its conservation status

\subsubsection{Large private landholding}

These ownerships cover the majority of the study zone (see figure 29). There is not a complete register of the number of landholdings. In this study, 96 ownerships were inventoried. They occupy $24 \%$ of the whole area (see table 31). Most of these ownerships are cattle ranches but logging is carried out on a few of them.

According to the Ecoregional analysis, while $78 \%$ of the inventoried surface in large holdings has a good or very good conservation status, $18 \%$ has a critical or very critical status, especially due to extensive deforestation processes. Fifteen percent of the areas with a high biological-ecological value place within the 96 registered holdings; however, this amount may be even bigger taking into consideration that large landowners are likely holding the rest of the lands. 
Table 31: Statistics data of large cattle holdings

\begin{tabular}{|l|l|}
\hline Total registered area & $499,039.91$ ha \\
\hline Number of registered landholdings & 96 \\
\hline Total number of landholdings & Unknown \\
\hline Average size of landholdings & $5,198.33$ ha \\
\hline Largest registered community & $71,964.36$ ha \\
\hline Smallest registered community & 84.37 ha \\
\hline Land size categories (ha) & Very big: $>10,000$ \\
& Big: $\quad 5,001-10,000$ \\
& Regular: $2,001-5,000$ \\
Small: $\quad 700-2,000$ \\
Very small: $<700$
\end{tabular}

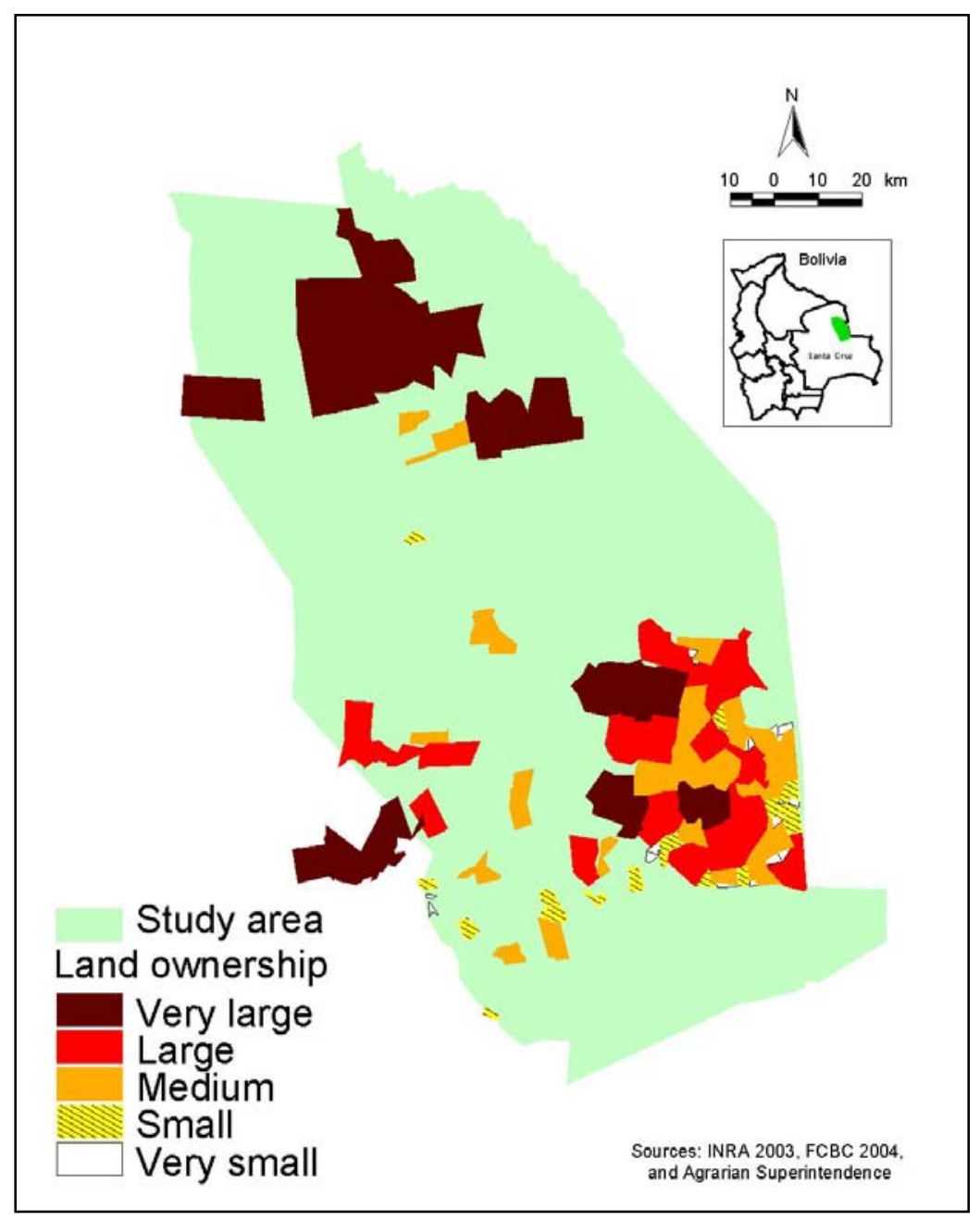

Figure 29: Location and categorisation of registered private holdings 
During the study period, natural areas in large holdings have undergone an intensive rate of conversion; mainly the areas in the surroundings of San Ignacio-San Matias road. For this reason, the involvement of landowners in conservation efforts is very important in order to avoid a large fragmentation of forest and as a consequence the loss of biodiversity.

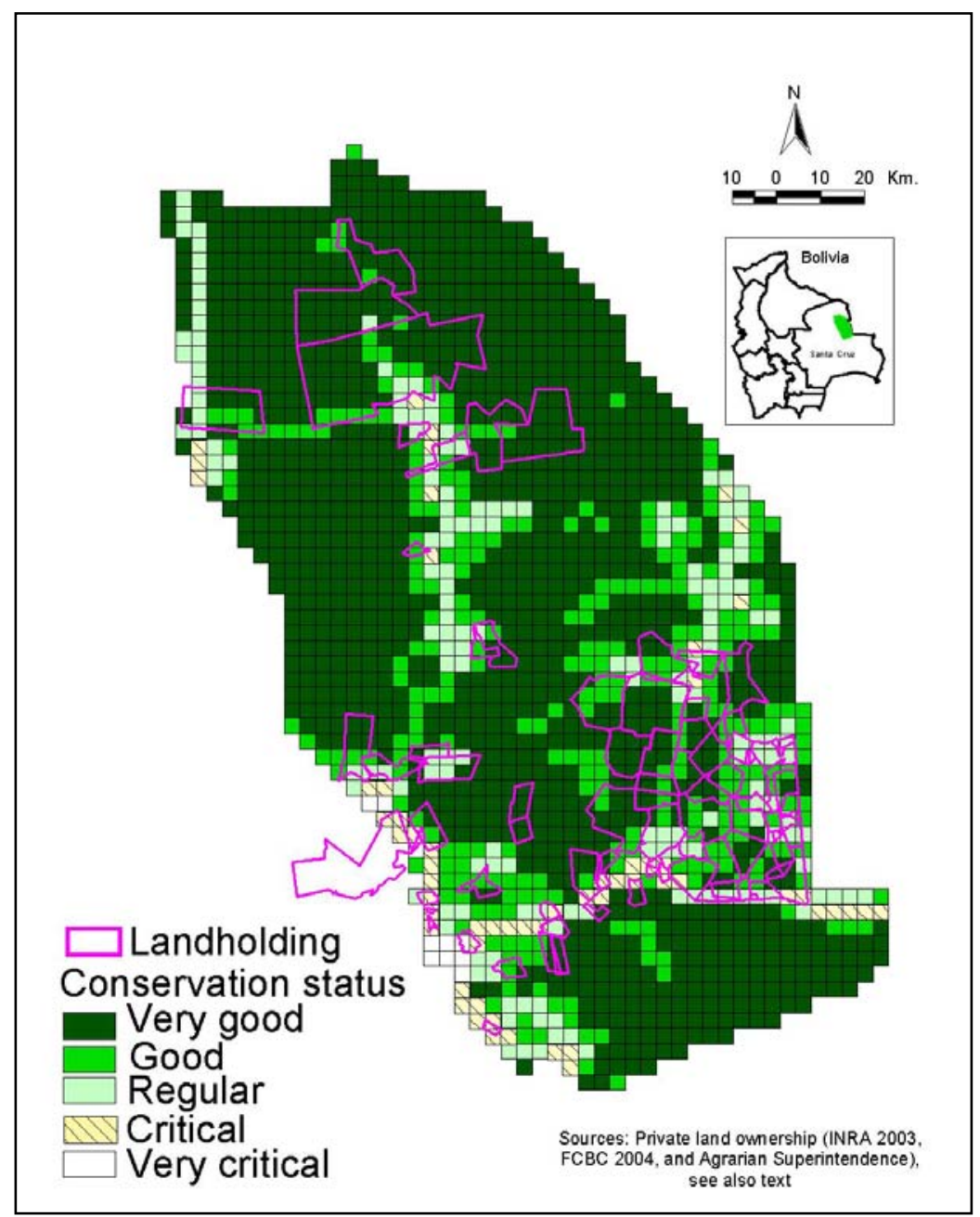

Figure 30: Private holding locations and the conservation status of the study area

\subsubsection{Regulatory dispositions of land use}

In the study area, restrictions created by direct government regulations limit land use both on public and private lands. The major governmental dispositions that affect the intervention of humans in natural areas are the General Land Use Plan of the Santa Cruz Department and the Administrative Conservation Easements under Bolivian Forestry Law (Law No. 1700).

The General Land Use Plan of Santa Cruz (PLUS) was generated in order to organise the sustainable use of natural resources in this department taking into consideration the potentials and properties of soils and their erosion risks (Prefectura del Departamento de Santa Cruz 1996). The PLUS was carried out at a time when biodiversity concern had not yet achieved 
the importance as today and the design of protected areas was conducted to emphasise soil conservation and frontiers protection (Ibisch 2004; Nowicky 2004).

According to PLUS, the study area encompasses three categories of permitted land use, in the order of importance: forestry, extensive agriculture and agroforestry-cattle raising (see table 32 and figure 31). As mentioned in chapter 5.1.3.5, until 2003 human intervention was very low in the studied region. With regard to the land use in the intervened areas, it has been approximately the intensity as had been planned; nevertheless isolated cases of large and unauthorised land conversion, which have occurred during a short time of economic prosperity, show the weak enforcement of this legal disposition.

Table 32: Surface and percentage of land use categories in the study zone according to the General Land Use Plan of Santa Cruz Department

\begin{tabular}{|l|r|r|}
\hline \multirow{2}{*}{ Category of land use } & \multicolumn{2}{c|}{ Surface } \\
\cline { 2 - 3 } & ha & \multicolumn{1}{c|}{ Percentage } \\
\hline Forestry & $993,831.04$ & 48.76 \\
\hline Extensive agriculture & $699,908.66$ & 34.34 \\
\hline Agroforestry and cattle-raising & $337,905.27$ & 16.58 \\
\hline Water-bodies & $6,562.12$ & 0.32 \\
\hline Total & & 100 \\
\hline
\end{tabular}

Source: elaborated after Prefectura del Departamento de Santa Cruz (1996)

To ensure the forest potential of Bolivia, the government passed the so called "New Bolivian Forestry Law". It set the legal restrictions of the "Permanent Forestry Areas" and "Administrative Conservation Easement". The former protects the most valuable forest territories allowing only controlled logging, and the latter protects fragile soils such as slopes/hillsides, water bodies, windbreak curtains and aeolian soils.

The geographic area of the Forestry Law Restrictions can be seen in figure 31 . As is shown in this map, "Permanent Forestry Areas" encompasse a large area (see table 33), which is quite similar to the category of forestry areas after the PLUS and also covers a surface without natural forest. Visible "Administrative Conservation Easements", namely steep slope areas, water bodies and streams, occupy less surface than the forestry areas but they have a high value for biological conservation on private ownerships because landowners have to reserve this areas for natural vegetation and wild fauna. 


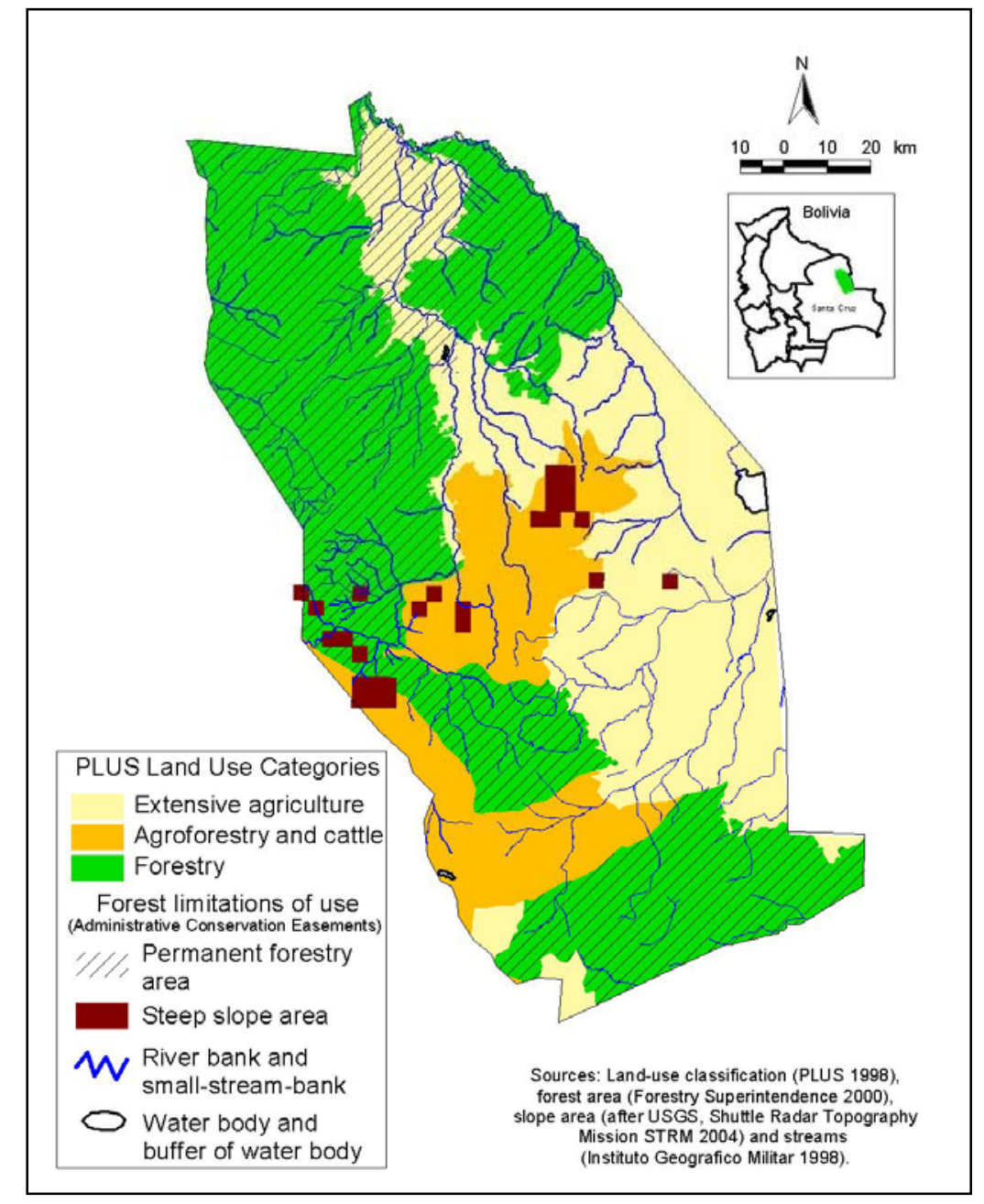

Figure 31: Geographical cover of regulatory dispositions of land use

The total area with legal restrictions according to the Forestry Law should be highlighted. More than half of the area (58\%) is under use restrictions (see table 33 and figure 31), in other words, conversion of natural ecosystems is forbidden and the enforcement of these legal limitations could be a major part of a strategy for conservation on private lands. However, as in the case of the PLUS there are failures in the control and monitoring system of legal restrictions. For instance large cattle producers have achieved to get the approval for land conversion in forestry areas with the argument that their forest areas have little economic value.

Although the landowners in the study area have not enforced the legal restrictions, the current good conservation status justifies measures to save important places. Most cases of transgression of legal natural resource regulations have occurred because the landowners did not know these dispositions, and did not realize the benefit of these measures. In this case, environmental education, enhancement of local monitoring of regulations and improvement of 
land planning, for instance, could lead to the participation of the proprietors in the conservation of natural areas.

Table 33: Surface and percentage of areas with legal use restrictions according to the Bolivian Forestry Law in the study area

\begin{tabular}{|l|l|r|r|r|}
\hline \multicolumn{1}{|c|}{ Legal restriction } & \multicolumn{1}{|c|}{ Category } & $\begin{array}{c}\text { Partial } \\
\text { surface in } \\
\text { the study } \\
\text { area }\end{array}$ & $\begin{array}{c}\text { Sum of } \\
\text { categories }\end{array}$ & $\begin{array}{c}\text { Percentage } \\
\text { of the study } \\
\text { area }\end{array}$ \\
\hline $\begin{array}{l}\text { Permanent forestry } \\
\text { areas }\end{array}$ & & $1,095,177.60$ & 53.57 \\
\hline Ecological easement & $\begin{array}{l}\text { River banks and small-stream- } \\
\text { banks }\end{array}$ & $34,922.00$ & $77,075.54$ & 3.77 \\
\cline { 2 - 4 } & Steep slope areas & $35,591.42$ & \\
\cline { 2 - 4 } & Buffer of Water-bodies & $6,562.12$ & \\
\cline { 1 - 4 } Total & \multicolumn{2}{|c|}{$1,172,253.14$} & \\
\hline
\end{tabular}

\subsubsection{Opportunities for conservation under the land property situation}

During the carrying out of this study, a process to regularise the land tenure situation was carried out by the National Institute of Agrarian Reform (INRA). Thus, all land ownerships have to be mapped and proprietors have to demonstrate their legal rights showing an adequate socio-economic use of the land because one of the most important aims of the INRA is to avoid land speculation and unproductive land accumulation (Pacheco 2001a).

In this context, the different types of owners and forest concessionaires are taking measures to avoid land expropriation (in the case of large landowners and forest concessionaires) and to receive more land surface (in the case of communities). The map of the currently mapped holdings and public areas shows the existence of overlaps that may lead to conflicts (see figure 32). Nevertheless, up to now the process of land right revision is undertaken in a favourable social climate, in which the land use planning of holdings is one of the most important instruments to demonstrate the correct use of the land. Under these conditions, the enhancement of land planning, stressing biodiversity conservation, can lead to the establishment of areas which would improve the conditions for wildlife.

A general view of the land tenure situation shows the unequal distribution of land in the study area. While 96 large landowners occupy $25 \%$ of the study area, more than 10,000 inhabitants own only $5 \%$. The excessive accumulation of land - as is shown in this zone - is an indicator 
of underdevelopment and poverty, and may be a cause of future conflicts and the destruction of nature.

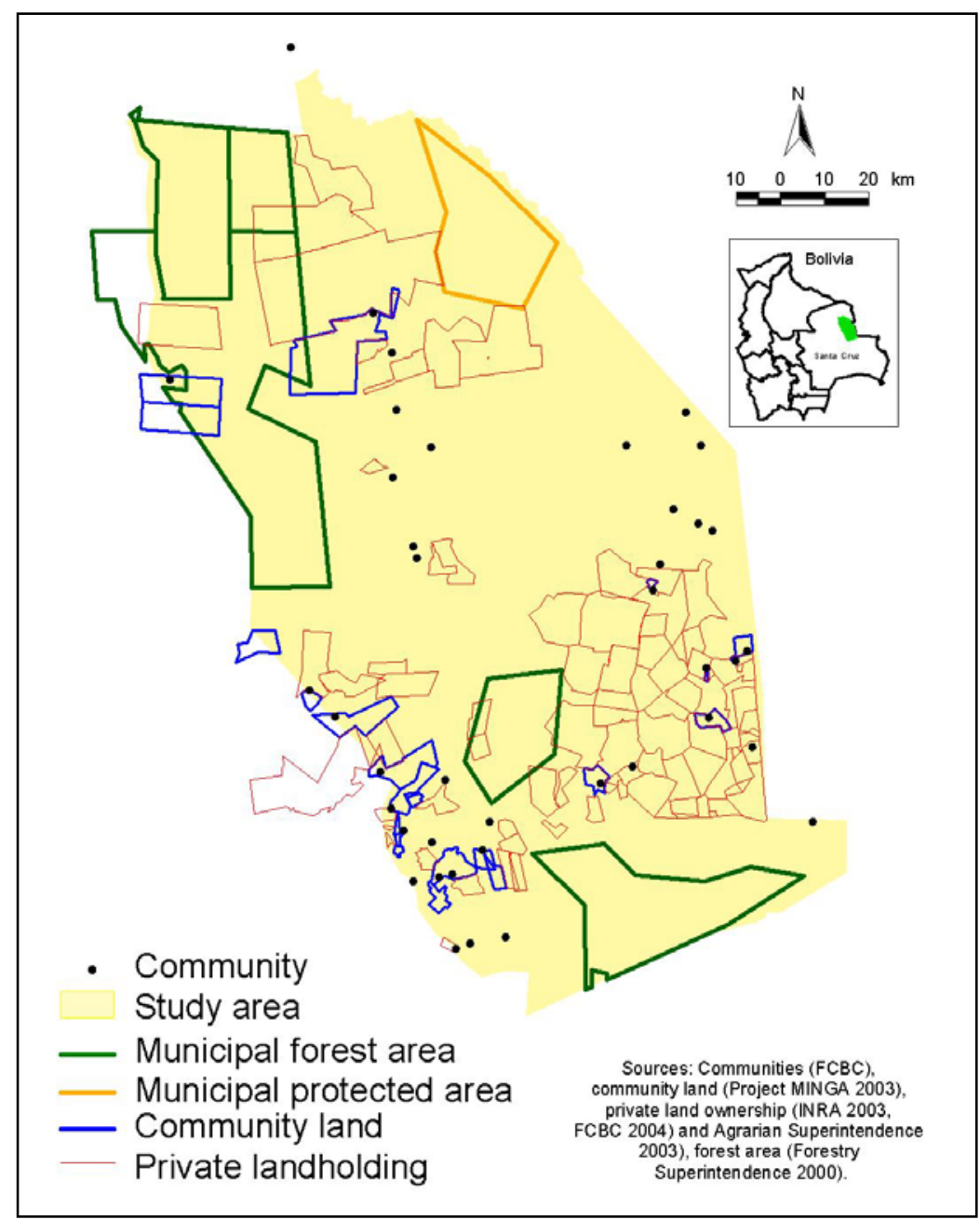

Figure 32: Land tenure overlap in the study zone

Social researchers, like Oporto (2003), recommend a process that leads to medium-scale holdings both to ensure democratic land distribution and effective use of the resources, because multiplying small properties is also negative in an economic and environmental sense, as has been demonstrated in the areas of the colonists (Steininger et al. 2001). However, this proposal would not be the best and most adequate option for the study area, in particular considering social constraints and natural limitations. Under current circumstances, measures such as the enhancement of multi-purpose-farming, improving forest productions through transforming of wood, development of non-agricultural and others activities are could be more realistic options to avoid deforestation and to enhance social development than land distribution (Loening \& Markussen, 2003). 


\subsubsection{Spatial priorities and critical conservation areas}

The socio-economic conditions of the study zone delimit the possibilities of conservation, although environmental laws and their regulation establish a certain grade of compulsory protection. For this reason, identification of priority areas, i.e. places with biological importance and, at the same time, with the best chances for conservation, will allow to carry out a feasible conservation process in the study zone.

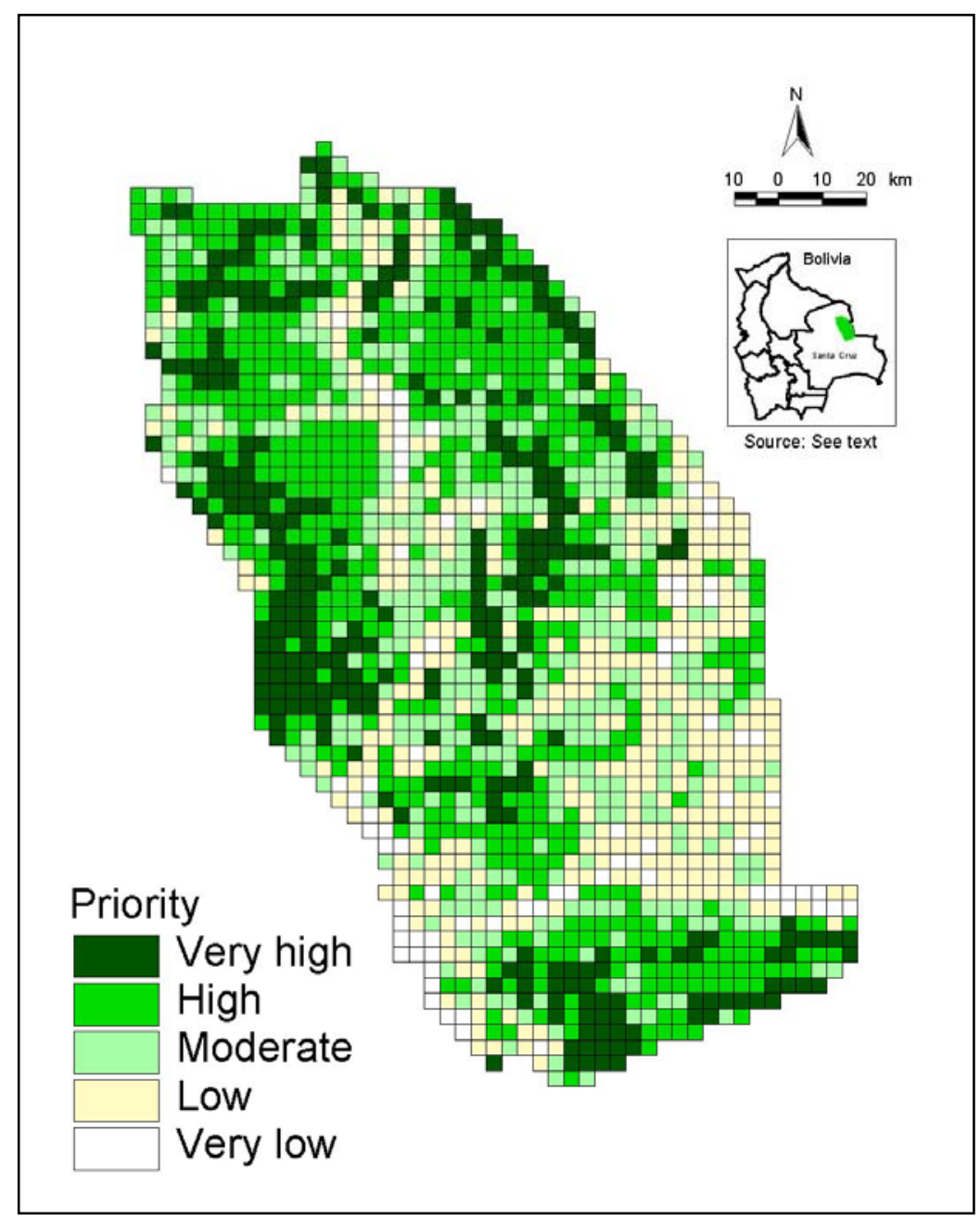

Figure 33: Spatial conservation priorities

In this study, spatial priorities were obtained from the integration of the bio-ecological valuation (discussed in 5.1.2.4.) and the conservation status (described in 5.1.2.4.). The result (displayed in figure 33) mainly highlights key-zones for connectivity and protection of environmental services and zones with low conversion of natural areas and currently low human pressure.

In detail, zones of very high priority are the riverbank of Tarvo River, the headwaters of Paragua River, Manomo Hill and their surroundings and finally the forested areas situated in 
the southern part (figure 33). Most of these areas are located in natural forest ecosystems (Chiquitano Forest ecoregion), only the surroundings of Manomo Hill encompass open areas (Cerrado and Savanna). In contrast, places with low priority coincide mainly with open areas (Cerrado and Savanna) and locations near roads. These areas have had an intensive human intervention and are likely to have a lower potential for sustainable conservation.

With regard to areas of low priority, the buffer zone along the San Ignacio-San Matias road was classified as such, but this area has a great importance, since it plays an important role in the connectivity of the Chiquitano forest. Therefore, this area must be considered as priority zone for conservation, too. Because whatever measure of conservation is taken, it will be ineffective in the long-term if the connectivity of the Chiquitano forest is not ensured.

Relating the places of high spatial priority with the land tenure situation it can be established that municipal forest plots and the municipal protected area house the highest percentage of areas with a high priority value. Therefore, the first recommended strategies for integral conservation of the zone should be to improve the protection and management of those municipal areas, and to join those territories through conservation measures available outside public land.

According to the ecoregional analysis, the areas that may link the forest and the protected areas represent only about $20 \%$ of the whole zone (see figure 34 ). The land property rights of these link-areas are not exactly described, but it is known that those places are mainly in the hands of private landowners and, in a few cases, in community hands. For these reasons, private land conservation was mainly tested on these mentioned link-areas, as will be discussed in the next chapters.

Under paragraph 5.1.4.4., it has been stated that forested areas with a legal status may ensure a certain level of wildlife protection, but these regulations do not cover open areas such as the Manomo Hill-outskirt, and the intermediate areas crossed by the road San Ignacio- San Matias. Thus, this is a legal argument to promote the participation of landowners and communities in activities of conservation. 


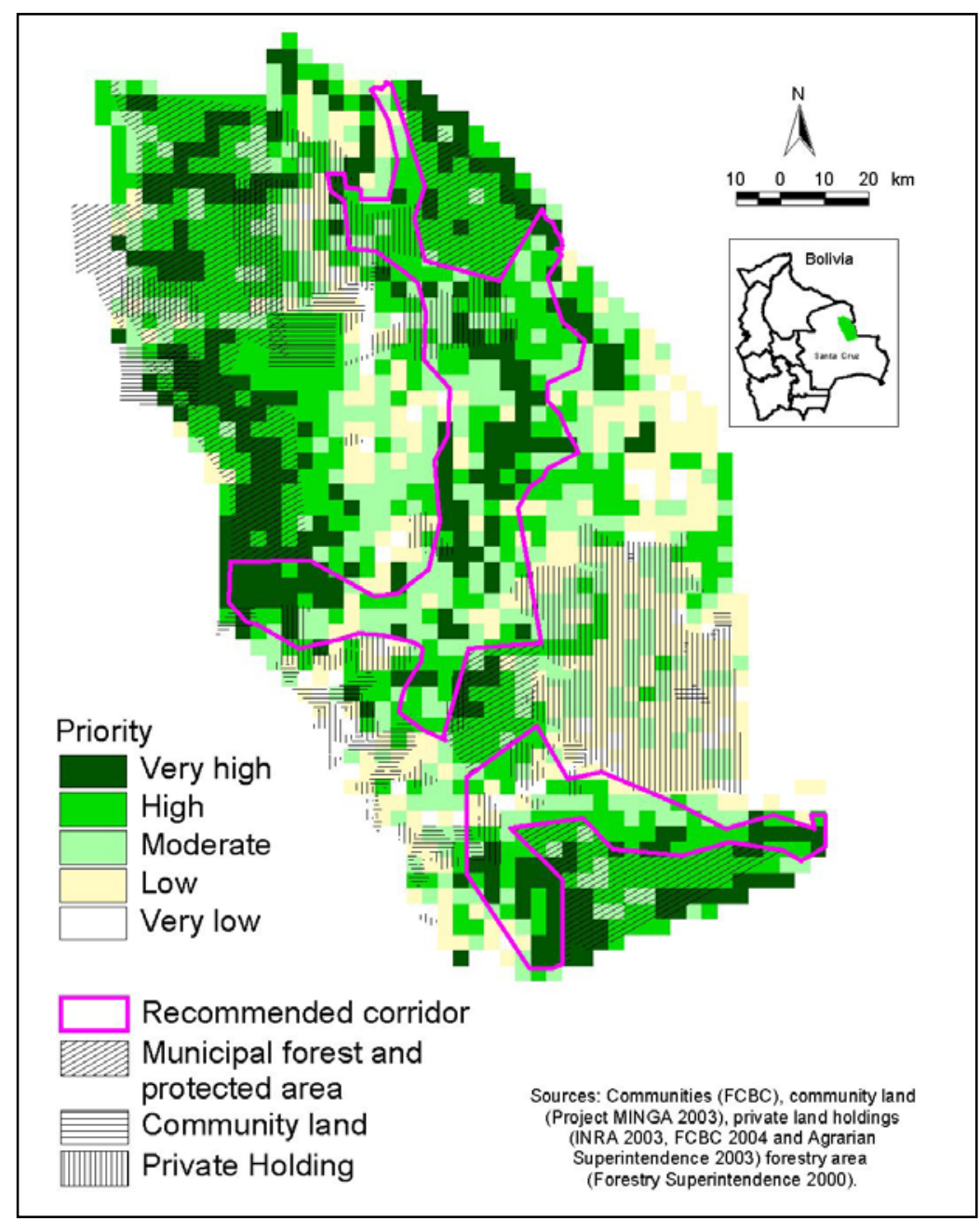

Figure 34: Relation between spatial conservation priorities and land tenure underlining recommended corridors outside public areas

\subsubsection{Conservation vision}

In the last chapter, areas with high spatial priority for conservation and the areas recommended for private land conservation were identified. Now we will go beyond this and propose further conservation options considering the socio-economic context.

The establishment of a preliminary "conservation vision" map was undertaken in order to show all possible measures that could help to maintain a harmonious balance between conservation and human activities. The map integrates the general land use plan (PLUS), legal regulations and the results obtained in the valuation of the spatial priorities. Thus, categories of land use are proposed taking as reference the nomenclature recommended in "The Conservation and Sustainable Plan for the Chiquitano Dry Forest, Cerrado and the Bolivian Pantanal (PCDS)" undertaken by Ibisch et al. (2002). 
The conservation map of this study should be considered as a preliminary attempt to design a final map of a conservation vision, because the elaboration of it did not consider the opinions and visions of the stakeholders, however, basic guidelines are presented in this map and they may contribute to a future process of municipal land use planning.

The categories of land use recommended can be seen in figure 35. Their main characteristics are described in the following points:

\section{$\underline{\text { A. Current and proposed protected areas }}$}

Areas with the highest biological-ecological value and the ones best conserved are found in this proposed category, they represent $8.7 \%$ of the total area.

A1: Municipal Protected Area of San Ignacio. Protected area established by the municipality, it covers the western riverbank of the Tarvo-River. Until 2003, this area has not had a management plan and a financial budget.

A2: Proposal for the protected area of Manomo Hill. An area with the highest biological and ecological value in the study zone; for this reason, strict protection of it is justified. It is known that applications to declare the zone as protected area have already been made, but land property rights are unknown. If the conditions do not permit the establishment of a municipal or national protected area, then the establishment of one or more private reserves could alternatively be recommended.

A3: Proposal for the buffer zone of Manomo Hill. The outskirts of Manomo Hill are composed of forest and open areas. Probably private landholdings are established in those areas. Limitations in hunting and the conversion of natural areas would help the development of biodiversity. In this area, private reserves should also be promoted.

\section{B. Corridors of connectivity achieved through private reserves}

The most important areas for private land conservation represent almost $29.7 \%$ of the total area.

B1: Proposal for connectivity corridors. These territories are important to insure the connectivity between the Chiquitano Forest and the Amazon and at the same time to avoid the isolation of the Noel Kempff National Park. The establishment of private protected areas is recommended in this zone, alternatively the promotion of the sustainable use of the forest can improve the connectivity. Due to its importance for the region, it is suggested that immediate 
actions must be taken, because the threat of the fragmentation of the Chiquitano Forest is very high.

B2: Proposal for managed forests on private landholdings and community lands. These zones have a good forest cover but they are highly influenced by human activities coming from the open areas.

\section{Forests under sustainable management}

C1, C2, C3: Private and communal forestry concessions (ASL). There are currently various forestry concessions in this zone. Especially the concessions that abide by the forestry law are an opportunity to practise conservation. This zone is important in the formation of a conservation block with sustainable forest management. The conservation of these forests, along with those in zone $\mathrm{C} 3$, is of utmost importance in the internal connectivity of the Chiquitano Forest.

\section{$\underline{\text { E. Sustainable farming areas }}$}

E1: Extensive farming. Zone defined in the PLUS. The E1 zones lie in flood-prone savannas, which are suitable for extensive cattle farming due to their areas of natural pastures. Marginal suitability also for agriculture because of low and irregular rainfall and high risk of wind erosion. It has a low to limited potential for forestry with a low capacity for natural regeneration. Extensive cattle farming already exists.

E2: Agro-silvopastoral. Zone defined in the PLUS. These areas are of limited agricultural use due to their infertile shallow soils with a high risk of degradation. Apart from this limitation, climatic conditions are more favourable for cattle farming than agriculture because of the scarcity of rainfall. 


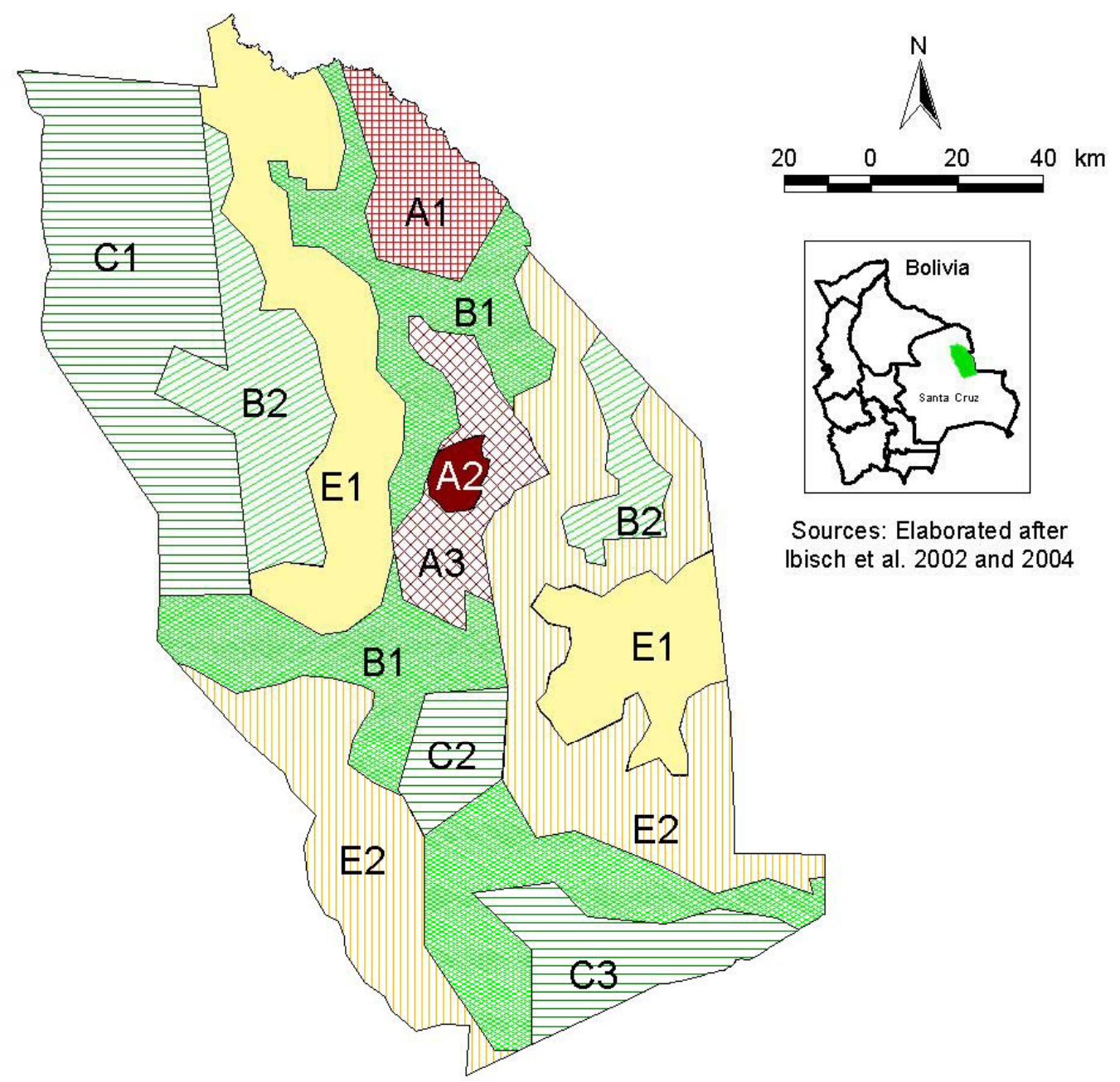

A1. Municipal protected area

A2: Mamono Hill proposed protected area

A3: Proposed bufferzone of Mamono Hill

B1: Connectivity corridors through private protected areas

B2: Forestry in private landholdings/ community lands

C1, C2, C3: Forests under sustainable management

E1: Extensive farming and cattle raising

E2: Agro-silvopastoral systems

Figure 35: Proposed preliminary conservation vision 


\subsection{Private landowners and biodiversity: the owners` predisposition to conservation}

In the last chapters, priority areas for biodiversity conservation were identified and it has been established that, outside public lands, the other key-conservation zones are mainly in the hands of large private landowners. These results highlight the necessity to work with these owners with the purpose of avoiding biodiversity destruction due to deforestation or overuse of the studied natural ecosystems.

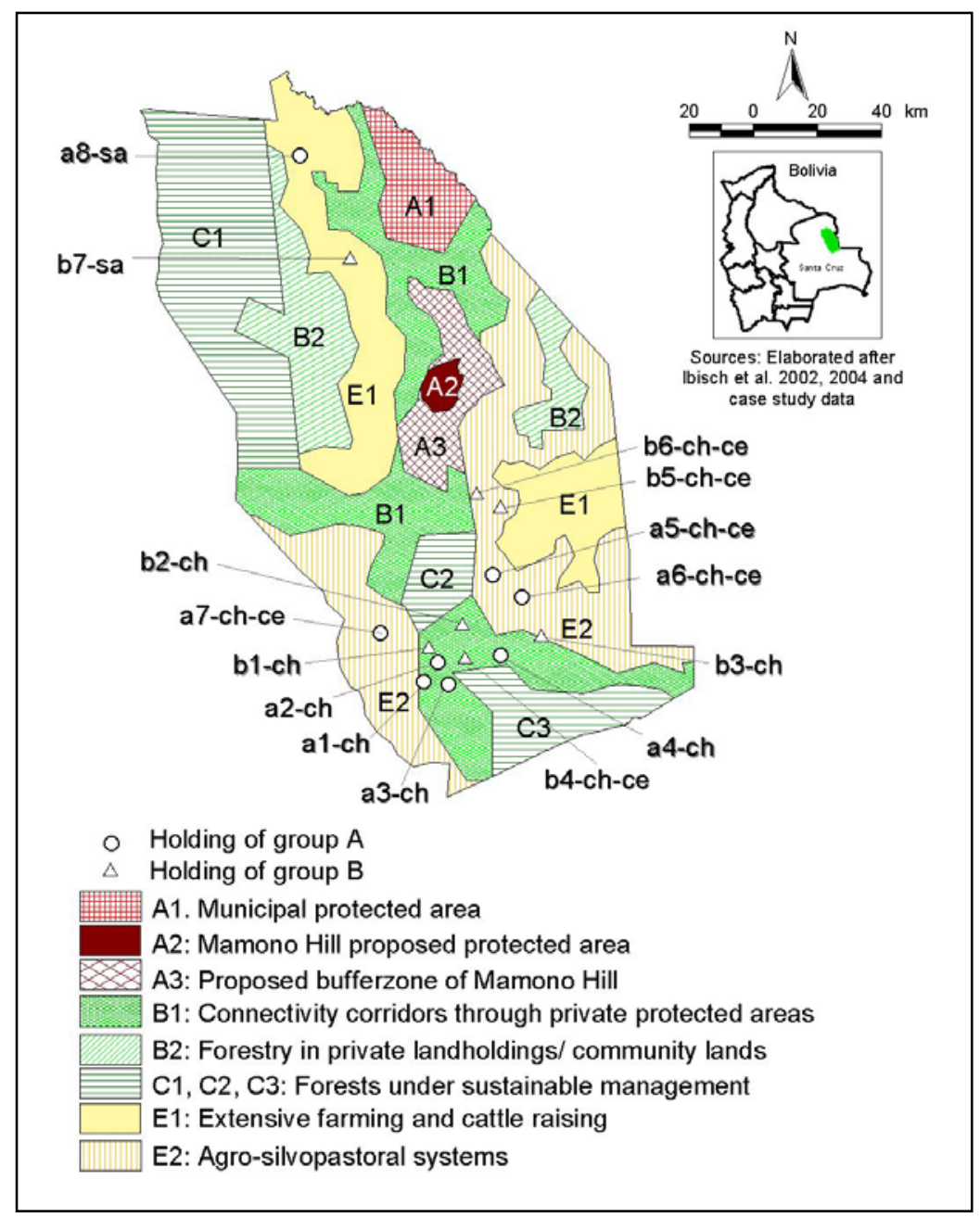

Figure 36: Location of selected case study and vision of conservation

In this section, the predisposition of private landowners to take part in biodiversity conservation is analysed and described. As was mentioned in the methodology, land use planning was carried out in selected holdings in order to introduce landowners to the possibility of setting aside areas for wildlife. 
The selected landholdings are located primarily in areas labelled for private land conservation according to the ecoregional analyse, but holdings in areas recommended for extensive farming and cattle raising were also involved, as can be seen in figure 36.

The proposal of the establishment of areas for wildlife protection on private holdings produced a pattern of land use according to the landowners' objectives and possibilities related to the environment. To understand the nature of these patterns, a description of the traditional land use (that is the form of use carried out without technical planning) is given first, followed by an analysis of the land-use designs accepted by the landowners.

\subsubsection{Traditional land use systems and their influence on biodiversity}

\subsubsection{Landholdings in the Chiquitano Forest ecoregion}

\section{Land use system}

Cattle farming is most frequently applied in the selected land ownerships located in this ecoregion (a1-ch, a2-ch, a3-ch, b1-ch, b2-ch and b3-ch). Although these properties have an almost continuous forest cover (see table 34 and figures 37, 43, 44 and 45), commercial logging is not undertaken. Some owners classify these properties as cattle ranches even though none or little production activities are carried out (as is the case of a1-ch, a2-ch, and a3-ch).

Soil limitations for agricultural production, scarce rainfall, low availability of top-commercial forest species and the lack of capital are the main factors that explain the preference of the cattle system. This farming system is characterised by an extensive use of resources. Forest conversion into grassland is normally undertaken by burning and the use of machinery (slash and burn by hand is more common on community lands). The use of machinery requires a high economic inversion (335 Us \$/ha according to Pattie \& Merry 1999), which represents almost $50 \%$ of the total cost to establish cultivated grasslands (Columba 2000). After the deforestation, cultivated grasses are established, in this area in particular species of the genus Brachiaria.

Nelore and rustic nelore cattle (Bos taurus indicus) are raised. The pastoral system is spontaneous, i.e. is without rotational practices, which rapidly degrades the established grasslands. After five years, the cultivated grasses have lost their quality and the necessity arises to clear new areas. 
Figure 37: Distribution in percent of traditional land use in holdings located in the Chiquitano Forest ecoregion

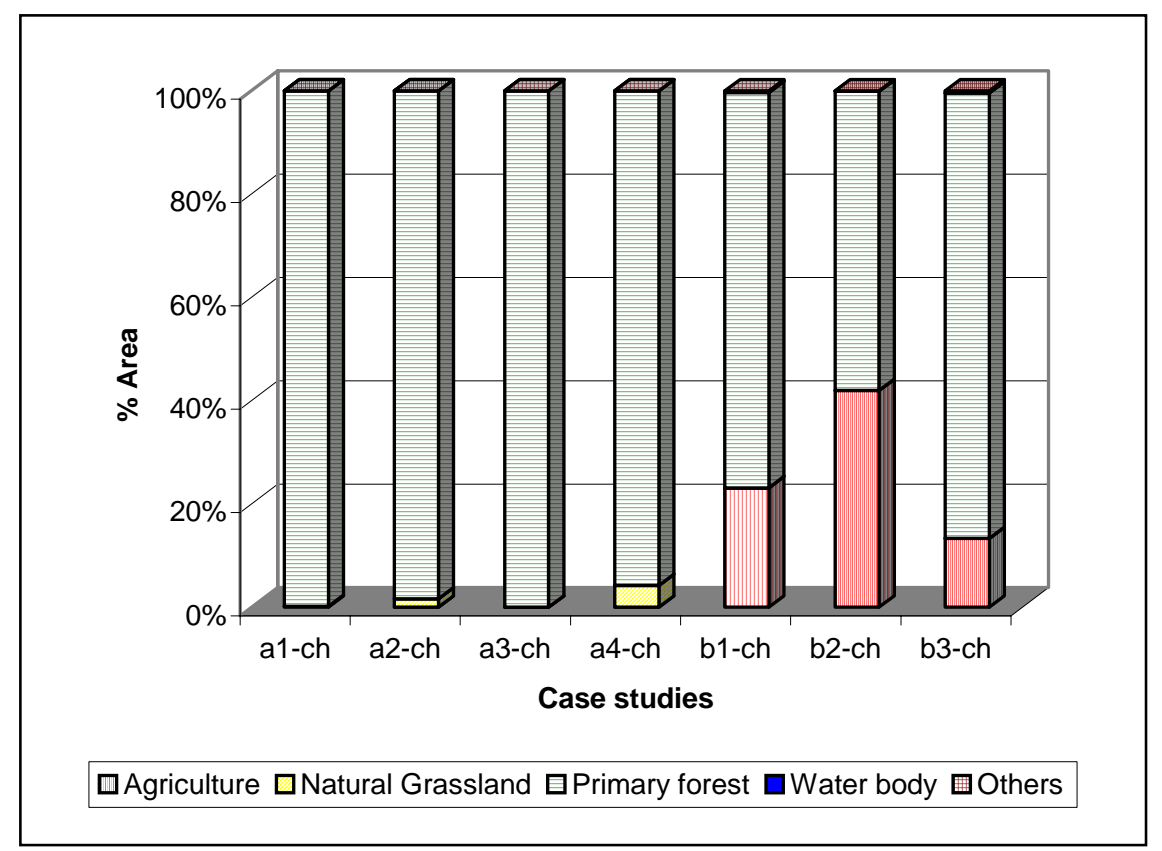

Source: Case study data

Table 34: Surfaces (ha) of land use under traditional farming. Holdings in the Chiquitano Forest ecoregion in the year 2002

\begin{tabular}{|l|r|r|r|r|r|r|}
\hline Case Study & Agriculture & $\begin{array}{c}\text { Natural } \\
\text { grassland }\end{array}$ & $\begin{array}{c}\text { Primary } \\
\text { Forest }\end{array}$ & Water body & Other & Total \\
\hline a1-ch & 4.00 & 0 & $2,374.90$ & 0 & 0 & $2,378.90$ \\
\hline a2-ch & 0 & 31.14 & $1,901.00$ & 0 & 0 & $1,932.14$ \\
\hline a3-ch & 0 & 0 & $2,427.52$ & 0 & 0 & $2,427.52$ \\
\hline a4-ch & 0 & 113.06 & $2,550.66$ & 0 & 0 & $2,663.72$ \\
\hline b1-ch & 331.63 & 0 & $1,097.12$ & 0 & 5.00 & $1,433.75$ \\
\hline b2-ch & $4,350.48$ & 0 & $6,009.09$ & 0 & 10.00 & $10,369.57$ \\
\hline b3-ch & 131.21 & 0 & 850.11 & 0 & 4.00 & 985.32 \\
\hline \multicolumn{7}{|c|}{ Source: Case study data } \\
\hline
\end{tabular}

Fire usually is used to enhance new shoots of grass and to control the undergrowths at the end of the dry-season (August). However, uncontrolled burnings usually harm closed forests.

The current low amount of commercial trees is a consequence of selective and uncontrolled logging before the establishment of the new Bolivian Forest Law. This selective logging has lowered the economic value of forests in these holdings and in most forested areas in the study zone both on private and on public lands. Nowadays forested areas are a part of the cattle systems, they represent as well a grazing space for the cattle in the dry season as a refuge in cold months. In addition, these forests supply domestic necessities of wood, for instance to build fences. 
Differences in the rate of deforestation in each holding are due to the available capital, landowners with more money have cleared more surface. For instance, the landholding b4, in which a large clearing was done, belongs to a rich Brazilian businessman; b1 and b2 are owned by Bolivian proprietors, who have large non-agricultural businesses as main economic source. In contrast the owners of group A, whose holdings show little deforestation, seem to have less capital since they are employees in public administration or private companies and depend on their salary for a living.

As was also mentioned by Patti \& Merry (1999) and Columba (2002), cattle farming does not seem to return enough benefits under current conditions. This fact explains why the proprietors do not invest in their holdings and why within the studied landholdings within three years only small areas have been deforested.

\section{Biodiversity status}

Conversion of wild species' habitats into pastures, changes in habitat quality caused by grazing, habitat disturbance that drives fauna away, changes in wild habitat quality by change in population density of other species and the direct use of fauna (hunting) and flora (firewood) are the main reasons for biodiversity degradation in the studied holdings, which obviously is most visible on the cleared lands.

However, while areas with an almost continuous forest cover show a good conservation status of birds, they show only a regular to critical conservation status for mammals, according to data gathered in four of the seven studied holdings. Figure 38 and table 35 show the number of species observed during rapid biological assessments and they are compared with the number of species expected for the Chiquitano ecoregion (Reichle et al. 2002). It can be seen from table 35 that the number of registered birds represents $80 \%$ of the expected number for this ecoregion. This seems to show a low impact of disturbance by cattle activities that are done in the cleared areas. However, studies like Woltmann (2000), Flores et al. (2001 and 2001a) indicate that the forest clearance allows also the colonization of non-local birds. Nevertheless, the mentioned number highlights the importance of forest protection for birds. In the case of mammals, the registered number amounts to only $26.3 \%$ of the expected number. This shows the negative effect of human activities on mammals especially through hunting. These results give an approach about the quantity of biodiversity loss when forested areas are converted into grassland areas. 
Figure 38: Comparison between the number of registered bird and mammal species in selected holdings of the Chiquitano Forest and the expected number of species for this ecoregion

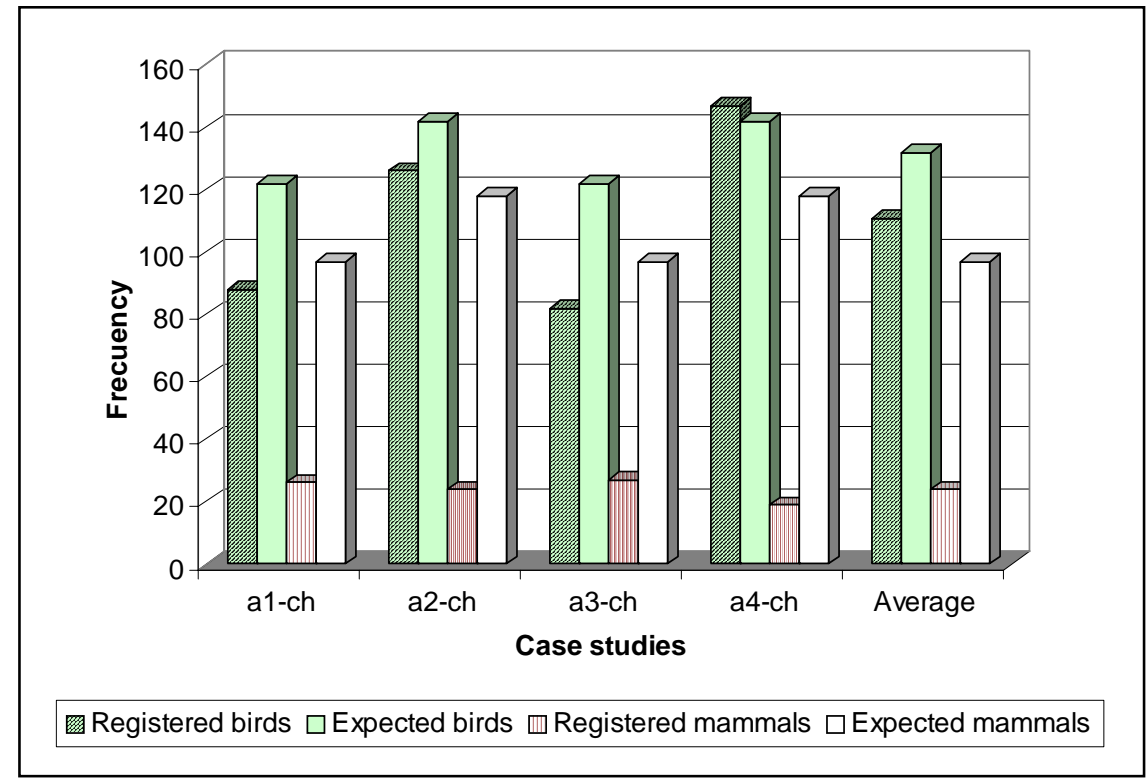

Source: Case study data

Sources: Number of birds and mammals after rapid biological assessments; expected number according to Reichle et al. (2002) (see annex 3).

Table 35: Number of species and families registered in rapid biological assessments in holdings of the ecoregion Chiquitano Forest

\begin{tabular}{|c|c|c|c|c|c|c|c|c|}
\hline \multirow{3}{*}{$\begin{array}{l}\text { Case } \\
\text { study }\end{array}$} & \multicolumn{4}{|c|}{ Birds } & \multicolumn{4}{|c|}{ Mammals } \\
\hline & \multirow{2}{*}{$\begin{array}{c}\text { Number of } \\
\text { registered } \\
\text { families }\end{array}$} & \multicolumn{3}{|c|}{ Number of species } & \multirow{2}{*}{$\begin{array}{c}\text { Number of } \\
\text { registered } \\
\text { families }\end{array}$} & \multicolumn{3}{|c|}{ Number of species } \\
\hline & & Registered & $\begin{array}{l}\% \text { of the } \\
\text { expected } \\
\text { number }\end{array}$ & \begin{tabular}{|c|} 
Expected \\
number
\end{tabular} & & $\begin{array}{c}\text { Regis- } \\
\text { tered }\end{array}$ & \begin{tabular}{|c|}
$\%$ of the \\
expected \\
number
\end{tabular} & $\begin{array}{c}\text { Expected } \\
\text { number }\end{array}$ \\
\hline a1-ch & 30.00 & 88.00 & 72.00 & 122.00 & 17.00 & 26.00 & 26.00 & 96.00 \\
\hline a2-ch & 39.00 & 126.00 & 88.70 & 142.00 & 13.00 & 24.00 & 24.00 & 118.00 \\
\hline a3-ch & 28.00 & 82.00 & 67.00 & 122.00 & 16.00 & 27.00 & 29.00 & 96.00 \\
\hline a4-ch & 44.00 & 147.00 & 103.50 & 142.00 & 10.00 & 19.00 & 19.50 & 118.00 \\
\hline Average & 32.20 & 110.75 & 80.60 & 133.00 & 14.00 & 24.00 & 26.30 & 107.00 \\
\hline
\end{tabular}

Source: Rapid biological assessment undertaken by MHNNKM and estimated number of species according to vegetation units after Reichle et al. (2002), see annex 3.

The direction of deforestation in those holdings has drawn attention to the fragmentation process. The observed deforestation increases from the roads to north or south, opening large open plots. This process must be controlled on the basis of land-use planning that takes the conservationist perspective into account. 


\subsubsection{Characteristics of landholdings both in the Chiquitano Forest and the Cerrado}

\section{Land use system}

The landholdings of this group (a4-ch-ce, a5-ch-ce, a6-ch-ce, b4-ch-ce, b5-ch-ce and b6-chce) lie in a transitional region between the Chiquitano Forest and the Cerrado. Natural open areas cover almost $40 \%$ of the total area of each holding as can be seen in figure 39 (see also table 36 and figures 47 and 48).

Figure 39: Distribution in per cent of land use under traditional system in holdings with characteristics of the ecoregions Chiquitano Forest and Cerrado

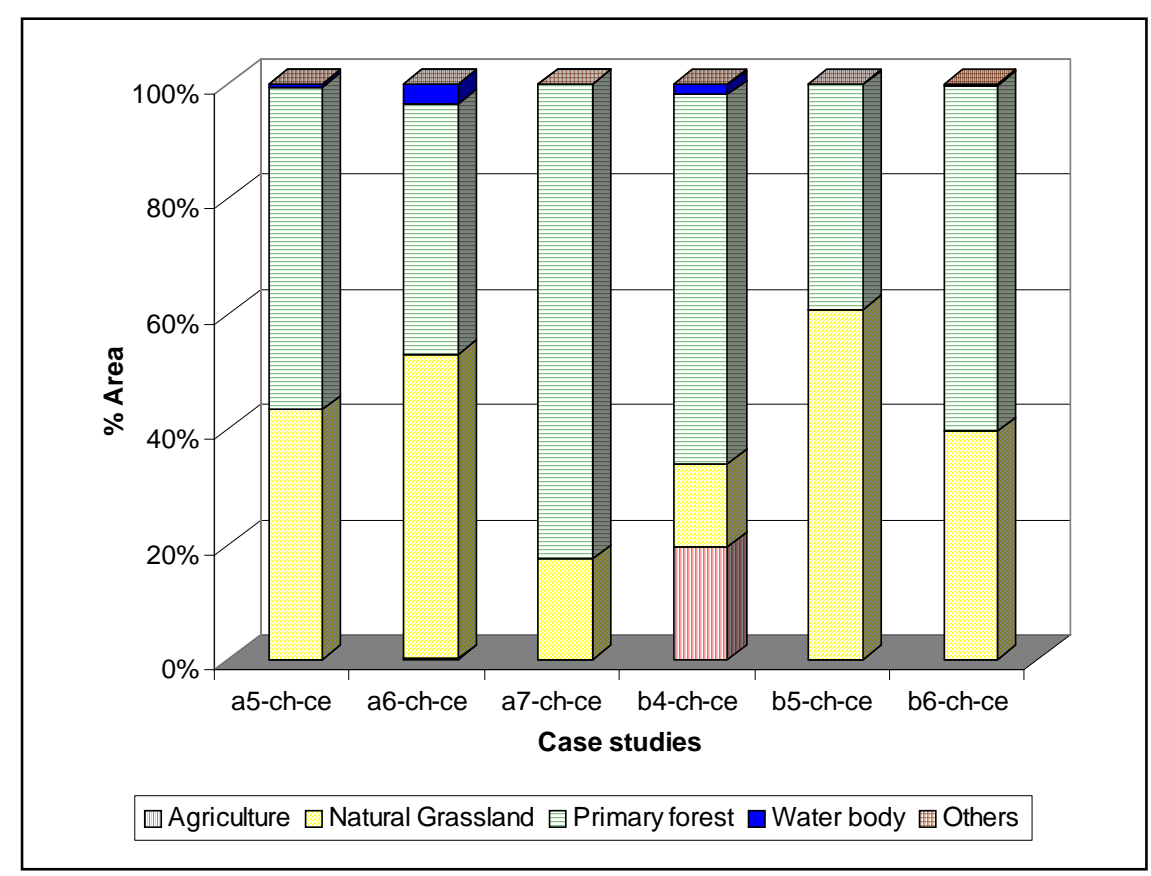

Source: Case study data

Table 36: Surfaces (ha) of land use under traditional farming. Holdings with characteristics of the ecoregions Chiquitano Forest and Cerrado in the year 2002

\begin{tabular}{|l|r|l|l|r|r|r|}
\hline Case Study & Agriculture & $\begin{array}{l}\text { Natural } \\
\text { grassland }\end{array}$ & $\begin{array}{l}\text { Primary } \\
\text { Forest }\end{array}$ & Water body & Other & Total \\
\hline a5-ch-ce & 0 & $1,200.90$ & $1,555.70$ & 17.41 & 0 & $2,774.01$ \\
\hline a6-ch-ce & 5.04 & $4,898.64$ & $4,029.58$ & 311.95 & 4.00 & $9,249.20$ \\
\hline a7-ch-ce & 0 & 468.05 & $2,208.84$ & 0 & 0 & $2,676.89$ \\
\hline b4-ch-ce & $1,413.30$ & $1,038.01$ & $4,625.97$ & 122.68 & 13.41 & $7,213.37$ \\
\hline b5-ch-ce & 1.20 & $10,711.37$ & $6,887.02$ & 0 & 32.32 & $17,631.91$ \\
\hline b6-ch-ce & 0 & $4,645.16$ & $7,027.27$ & 0 & 38.30 & $11,710.74$ \\
\hline
\end{tabular}

Source: Case study data 
The productive system applied in those holdings could be classified as cattle rising, in which, open areas (wooded savanna, open savanna and flooded savanna) are used for grazing of nelore and rustic nelore cattle.

Small surfaces of natural open areas have been converted to grassland (see figures 47 and 48) because of poor soil (Wachholtz, 2002). Although the quality of the natural grasses is low, they maintain an extensive cattle activity in those landholdings. Fire is used to ease new shoots but also natural fires occur in dry seasons (Killen et al. 1998).

Forest areas of those landholdings have a low potential because most of them are transitional areas where non-commercial tree species of the Cerrado dominate so that most forest surfaces are grazed by cattle. However, these forest zones supply wood for domestic use. The conversion of forest areas into grassland is very small due to the high costs.

Scarcity of water is the main natural constraint for cattle and agricultural production. The presence of natural water bodies is one of the most precious resources. Some landowners have invested in the construction of small artificial water reservoirs, but the costs are relatively high.

\section{Biodiversity status}

The same factors as described above in 5.2.1.1. (conversion of wild species' habitats into pastures, habitat disturbance that drives fauna away, changes in wild habitat quality by change in population density of other species and the direct use of fauna (hunting) and flora (firewood)) degrade biodiversity also in this kind of holdings but changes in habitat quality caused by grazing is probably the most relevant factor.

The rapid evaluation of bird and mammal diversity, undertaken in three holdings in areas of the Chiquitano and the Cerrado shows that the amount of registered birds is quite similar to the expected number for this area (see figure 40 and table 37). This result may suggest that extensive cattle ranching has a low impact on the bird population, especially when the amount of forested areas is maintained. On the contrary, registered mammals are very few indicating that cattle farming may displace mammal populations both due to disturbance and indirect competition.

With regard to the possibilities of conservation in this kind of land holdings, the protection of open areas is more difficult than of forested areas because of the uncontrolled grazing system of cattle. However, up to now there are no probes that indicate a total incompatibility between 
cattle production and conservation (hardly any studies have been done about cattle and their effects on biodiversity).

Figure 40: Comparison between the number of registered species in holdings with characteristics of the Chiquitano Forest and the Cerrado and the expected number of species for these areas

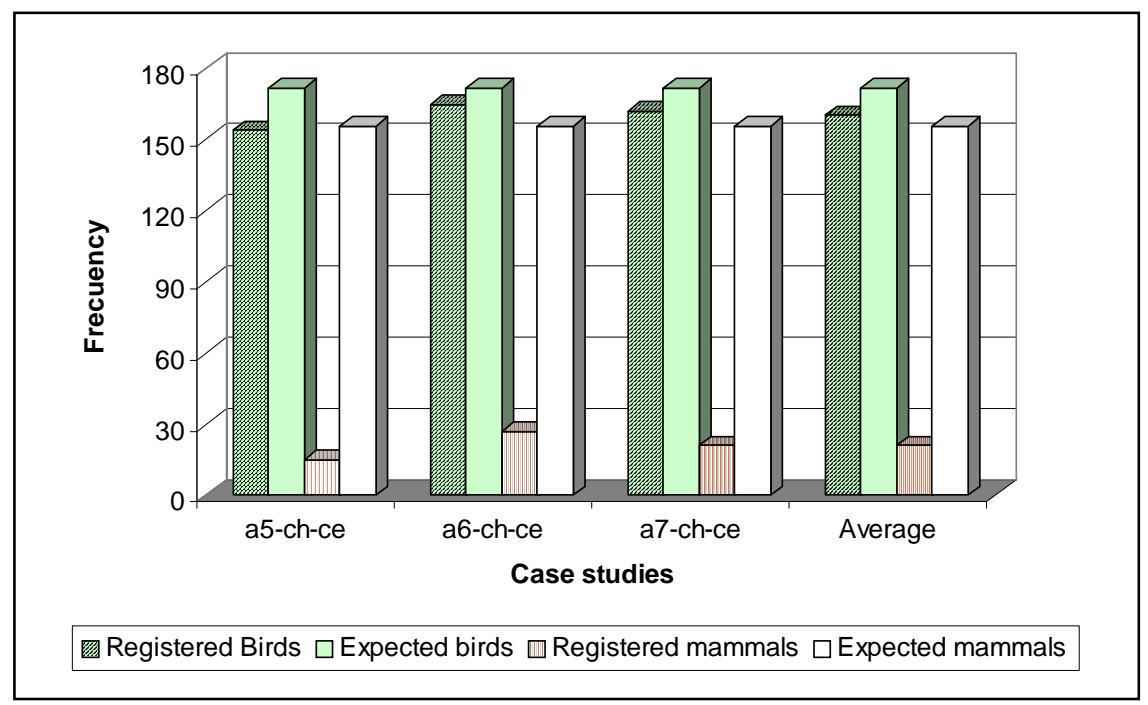

Sources: number of birds and mammals after rapid biological assessments undertaken by MHNNKM; expected number according to Reichle et al. (2002) (see annex 3).

Table 37: Number of species and families registered in rapid biological assessments in holdings with characteristics of the Chiquitano Forest and The Cerrado ecoregions

\begin{tabular}{|c|c|c|c|c|c|c|c|c|}
\hline \multirow{3}{*}{$\begin{array}{l}\text { Case } \\
\text { Study }\end{array}$} & \multicolumn{4}{|c|}{ Birds } & \multicolumn{4}{|c|}{ Mammals } \\
\hline & \multirow{2}{*}{$\begin{array}{l}\text { Number } \\
\text { of } \\
\text { registered } \\
\text { families }\end{array}$} & \multicolumn{3}{|c|}{ Number of species } & \multirow{2}{*}{$\begin{array}{l}\text { Number } \\
\text { of } \\
\text { registered } \\
\text { families }\end{array}$} & \multicolumn{3}{|c|}{ Number of species } \\
\hline & & Registered & $\begin{array}{l}\text { \% of the } \\
\text { expected } \\
\text { number }\end{array}$ & $\begin{array}{l}\text { Expected } \\
\text { number }\end{array}$ & & Registered & $\begin{array}{l}\% \text { of the } \\
\text { expected } \\
\text { number }\end{array}$ & $\begin{array}{l}\text { Expected } \\
\text { number }\end{array}$ \\
\hline a5-ch-ce & 45 & 154.0 & 89.5 & 172 & 11 & 15 & 9.6 & 156 \\
\hline a6-ch-ce & 48 & 165.0 & 95.9 & 172 & 17 & 27 & 17.3 & 156 \\
\hline a7-ch-ce & 45 & 162.0 & 94.2 & 172 & 14 & 21 & 13.5 & 156 \\
\hline Average & 46 & 160.3 & 93.2 & 172 & 14 & 21 & 13.5 & 156 \\
\hline
\end{tabular}

Source: Rapid biological assessment undertaken by MHNNKM and number of estimated species according to the vegetation units after Reichle et al. (2002) (see annex 3).

According to the field observations and landowners' opinions, good synergies exist between cattle production and biodiversity conservation. For example, grazing controls the excessive accumulation of natural vegetation that otherwise would contribute to an increase of natural fires in open and forested areas. On the other hand, wild fauna maintain vital processes like pollination or seed dispersal. 


\subsubsection{Landholdings in Amazon Flooded Savannas}

\section{Land use system}

Plain areas in this ecoregion are affected by seasonal flooding that covers a variable part of the holdings surface. For instance, almost $50 \%$ of the surface in the selected properties (a8-sa and b7-sa) suffer temporal inundation (see table 38, figure 41 and 50).

Consequently, under these conditions, the properties apply a cattle ranching system that is adapted to seasonal flooding. This system is similar to the farming systems used in the savannas of the Beni and the Pantanal (Columba 2002), where cattle rising is preferred because of their mobility and adaptability.

Figure 41: Distribution of land use under traditional system in holdings of the ecoregion of the Flooded Amazon Savanna

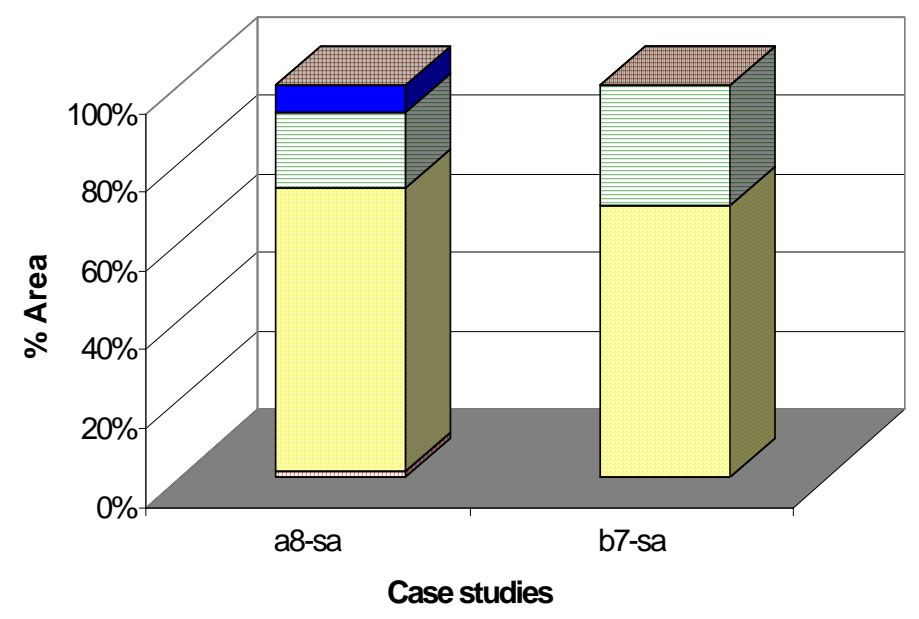

$\square$ Agriculture $\square$ Natural flooded Grassland $\square$ Primary forest $\square$ Water body $\square$ Others

Source: Case study data

Table 38: Surfaces (ha) of land use under traditional farming. Holdings in Flooded Amazon Savannas ecoregion, year 2002

\begin{tabular}{|l|r|r|r|r|r|r|}
\hline Case Study & Agriculture & $\begin{array}{c}\text { Natural } \\
\text { flooded } \\
\text { grassland }\end{array}$ & $\begin{array}{c}\text { Primary } \\
\text { Forest }\end{array}$ & Water body & Other & Total \\
\hline a8-sa & 203.72 & $10,104.63$ & $2,685.49$ & 982.17 & 9.90 & $13,985.91$ \\
\hline $\mathrm{b} 7-\mathrm{sa}$ & 0 & $1,537.61$ & 681.49 & 0 & 0 & $2,219.10$ \\
\hline
\end{tabular}

Source: Case study data 
During the dry-season cattle is raised in the open savannas. When natural flooding covers most of the open area, cattle is shifted to the uplands (normally occupied by forest) and forested islands. Then uplands represent an appreciated source for grazing of the cattle system in those holdings.

Within the holdings, the forest is only used for domestic necessities. Some properties have areas with valuable forest resources but the current market conditions and the lack of accessibility via roads do not induce to carrying out these activities.

Rotational grazing practices are little applied in these holdings and as a result, natural grasslands are under high pressure. Little surface of land is converted for agriculture and grasses (see figure 41 and 50), mainly the higher zones.

\section{Biodiversity status}

According to the ecoregional analysis, the conservation status in this area, in general, is very good, mainly because of its distant location from human settlements. Field observations confirm this statement and revealed that biodiversity in the considered holdings suffered low disturbance. The factors that could affect biodiversity in this region are changes in habitat quality caused by grazing, habitat disturbance that drives fauna away, changes in wild habitat quality by changes in the population density of other species and direct use of fauna (hunting) and flora (firewood).

Data of registered species of birds and mammals in one of the two evaluated properties (a8-sa and b7-sa), shown in figure 42 and table 39, illustrate the biodiversity situations in an area of 10,000 ha in this region. The mentioned evaluation determined 236 bird and 42 mammal species that respectively represent $30 \%$ and $33 \%$ of the number of registered species in the Noel Kempff Mercado National Park, which is located close to the evaluated area. Although this comparison may be discussed because of the large area of the National Park, which comprises intact habitats only, and the intensity of biodiversity studies undertaken there, it may improve the general idea of the natural potential existing in the private properties of this ecoregion.

The establishment of private protected areas in this location would be very important due to the influence of these areas on the Noel Kempff National Park, declared as World Heritage. 
Figure 42: Comparison between the number of registered species in the holdings of the

Flooded Amazon Savanna ecoregion and the registered number of the species of the Noel Kempff National Park

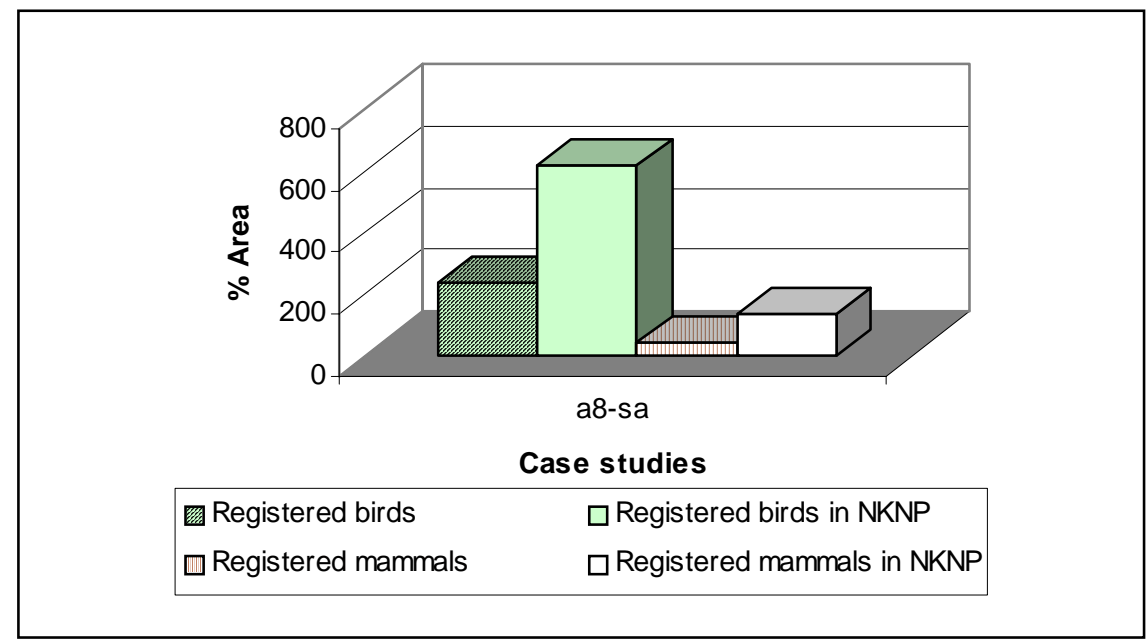

Sources: species number of birds and mammals after rapid biological assessments undertaken by MHNNKM and the Management Plan of the Noel Kempff National Park.

Table 39: Comparison of the number of species and families registered in rapid biological assessments in the holdings of the Flooded Amazon Savannas and the registered species of the Noel Kempff National Park

\begin{tabular}{|c|c|c|c|c|c|c|c|c|}
\hline \multirow{3}{*}{$\begin{array}{l}\text { Case } \\
\text { study }\end{array}$} & \multicolumn{4}{|c|}{ Birds } & \multicolumn{4}{|c|}{ Mammals } \\
\hline & \multirow{2}{*}{\begin{tabular}{|c|} 
Number \\
of \\
registere \\
$\mathrm{d}$ \\
families
\end{tabular}} & \multicolumn{3}{|c|}{ Number of species } & \multirow{2}{*}{$\begin{array}{l}\text { Number of } \\
\text { registered } \\
\text { families }\end{array}$} & \multicolumn{3}{|c|}{\begin{tabular}{|c|} 
Number of species \\
\end{tabular}} \\
\hline & & Registered & $\begin{array}{l}\text { \% Relating } \\
\text { with } \\
\text { NKNP }\end{array}$ & \begin{tabular}{|l} 
Number \\
register \\
in NKNP
\end{tabular} & & Registered & $\begin{array}{l}\% \text { relating } \\
\text { with NKNP }\end{array}$ & \begin{tabular}{|c|} 
Number \\
register in \\
NKNP
\end{tabular} \\
\hline 3 -sa & 57 & 236 & 38.2 & 617 & 21 & 42 & 30.2 & 139 \\
\hline
\end{tabular}

Source: Rapid biological assessment undertaken by MHNNKM and Management Plan of Noel Kempff National Park. 


\subsubsection{Land use pattern under conservationist perspective}

In this chapter land-use plans that were elaborated in selected holdings are presented and analysed. These plans take into consideration soil properties, legal regulations of land-use (PLUS, Forestry Low) and landowners' possibilities.

The landowners of these holdings were the main actors in the planning process; they were the ones who finally decided about the land-arrangement depending on their expectations and technical recommendations. The designs were considered as "proposed land-use plans", thus the owners could voluntarily follow the procedures to get the governmental approval of these plans (that is owners accepted the proposal of land use) or they could stop and change the land design (which means they rejected the plans).

The holdings' surfaces were classified in five categories of land use in order to simplify and ease the comparison among the land use systems: agricultural/introduced pastures, grazing in natural grasslands, forestry use, compulsory protected areas and voluntarily protected areas.

The probable impact of these proposed land-use arrangements on biodiversity conservation as well as the owners' motivations to select them are discussed highlighting elements that could be useful for a strategy of private land conservation.

For a better understanding, the land-use arrangements will be described below according to the ecoregion where landholdings are located. Here two groups where distinguished: the first type includes areas for wildlife conservation and the second one does not include these areas.

\subsubsection{Land use plans in the Chiquitano Forest ecoregion}

Proprietors of holdings a1-ch, a2-ch, a3-ch and a4-ch selected land-use designs in which little conversion of the natural ecosystem was planned and a large percentage of land was set-aside for wildlife (see figure 43, 44 and 46).

These designs are obviously very favourable for conservation because they allow the recovery of flora and fauna; in addition, they contribute to ending the fragmentation of the Chiquitano Forest. Nevertheless, the following management measures are needed to ensure the protection: the establishment of corridors against fire, a permanent control of illegal hunting, the avoidance of cattle grazing and in particular forestry measures to enhance the regeneration of specific tree species. 
The landowners of these four holdings did not have enough capital to implement large-scale land conversion (deforestation) at the moment of the land planning, they also did not have agriculture as main activity for their living. Most of them were living in big cities and therefore could not manage their rural properties.

On the one hand, the landowners' decisions to set-aside areas for voluntary conservation was based on their thinking about the future forest use rather than a real interest in the conservation of biodiversity. This is reflected in the short period of time that they chose for the voluntary protection (see table 43), which in most of these cases was the minimum established by law.

On the other hand, it should be underlined that the decision to establish natural reserves was also motivated by the landowners' interest to achieve recognition of their property land rights, because these landowners were not fulfilling the legal requirements to own land in Bolivia, which are basic to carry out productive activities or to have legally recognised land conservation areas.

Under the current land law in Bolivia, these owners might have got the recognition of land property by clearing the forest areas. But this would have destroyed the biological values described above. For this reason, the selection of a land-use design that includes a large surface for conservation benefits the wildlife protection and it allows to gain time in order to develop a future sustainable use of it, for example for controlled logging or ecotourism.

The landowners of the holdings b1-ch, b2-ch and b3-ch chose a land use design that includes the conversion of large natural areas into cultivated grassland (see figure 45 and 46). In those designs only the compulsory protected areas, i.e. windbreak curtains and buffers of water streams, are unique areas that will maintain the original native vegetation according to the land use plans. In none of these cases, forestry was taken into consideration because landowners have considered commercial forestry as not profitable. 
Figure 43: Comparison of the given land-use status in 2003 and the proposed land-use arrangement of the holdings located in the ecoregion of the Chiquitano Forest. Holdings a1-ch, a2-ch, and a3-ch

Original status of land-use

Sources: After land-use planning and stream data from Instituto Geografico Militar 1998 
Figure 44: Comparison of the given land-use status in 2003 and the proposed land-use arrangement of holding a4-ch, located in the Chiquitano Forest ecoregion

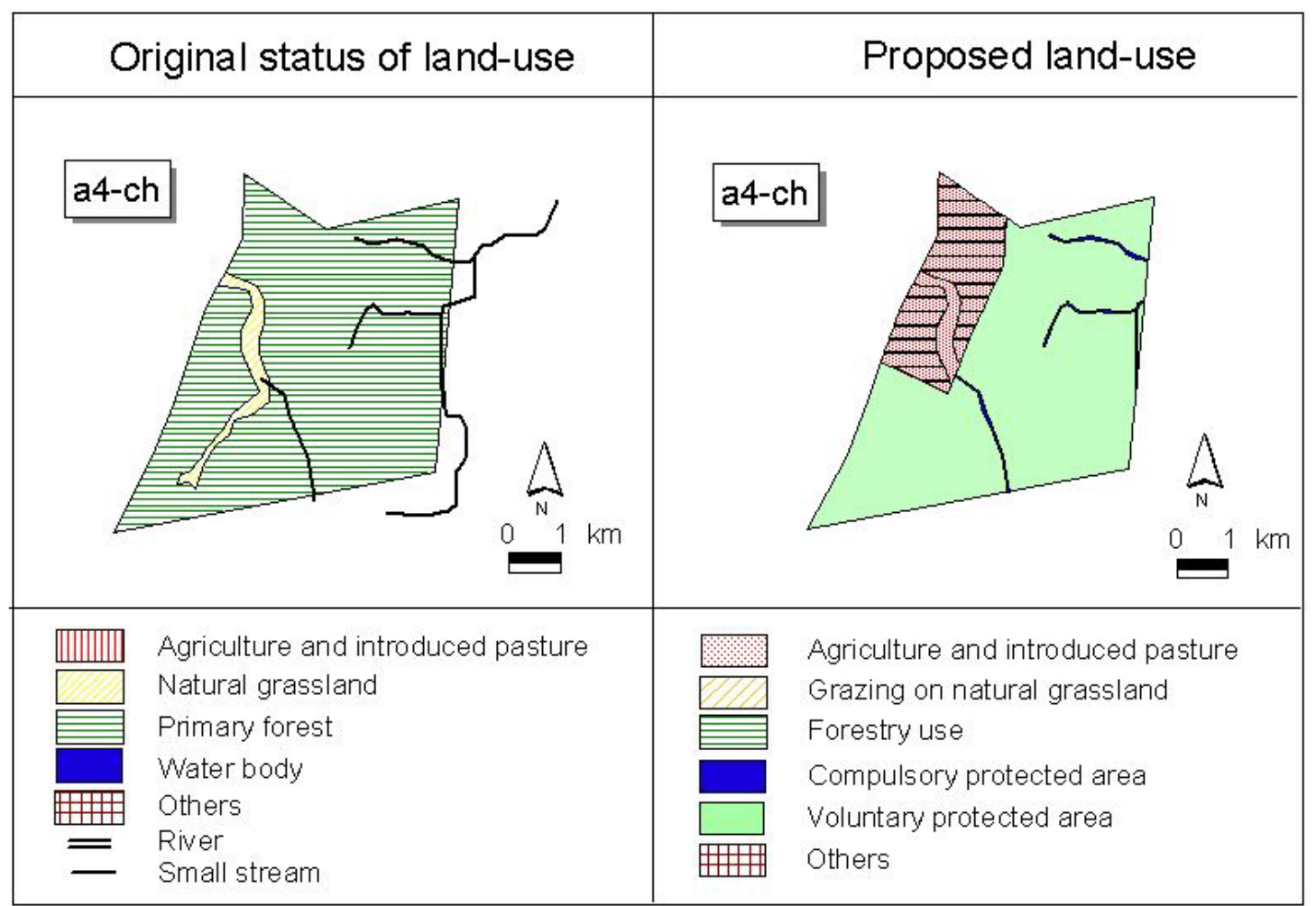

Sources: After land-use planning and stream data from Instituto Geografico Militar 1998

This type of land-use leads to the destruction of natural habitats and the fragmentation of the Chiquitano Forest. Here compulsory protected lands encompass less than $10 \%$ of the surface, which will probably contribute to stop the erosion processes but the areas are to small to form an important contribution to the remaining biodiversity. These kinds of plans have been realised/implemented on a large-scale in the development areas of the department of Santa Cruz (Krueger \& Gerold 2003, Steininger, 2001). Only in a few cases the establishment of compulsory protected areas was enforced by the proprietors, as a result not only the loss of biodiversity but also a high threat of soil degradation affect those lands.

Proprietors with better economic possibilities and historic tendency to aggressive production activities own the mentioned holdings. Concerning the land tenure situation of these proprietors, although they do not have land titles under the rules of the land law (INRA), they could easily justify their property right by showing production activities. Conservation is not in their interest in those cases. 
Figure 45: Comparison of the given land-use status in 2003 and the proposed land-use arrangement of holdings located in the ecoregion of the Chiquitano Forest. Holdings b1-ch, b2-ch, and b3-ch

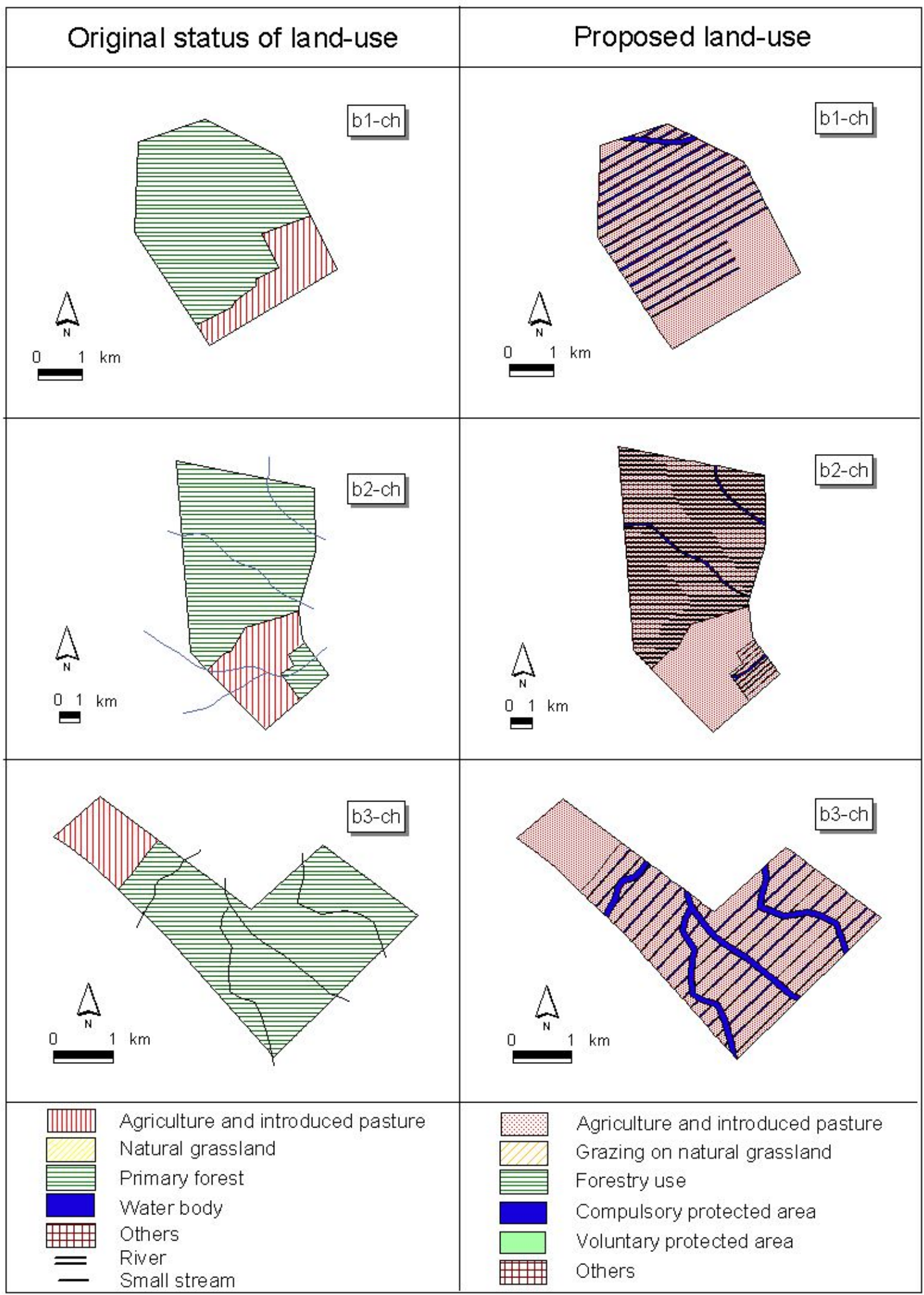

Sources: After land-use planning and stream data from Instituto Geografico Militar 1998 
Figure 46: Per cent distribution of the proposed land-use categories in each holding of the Chiquitano Forest ecoregion

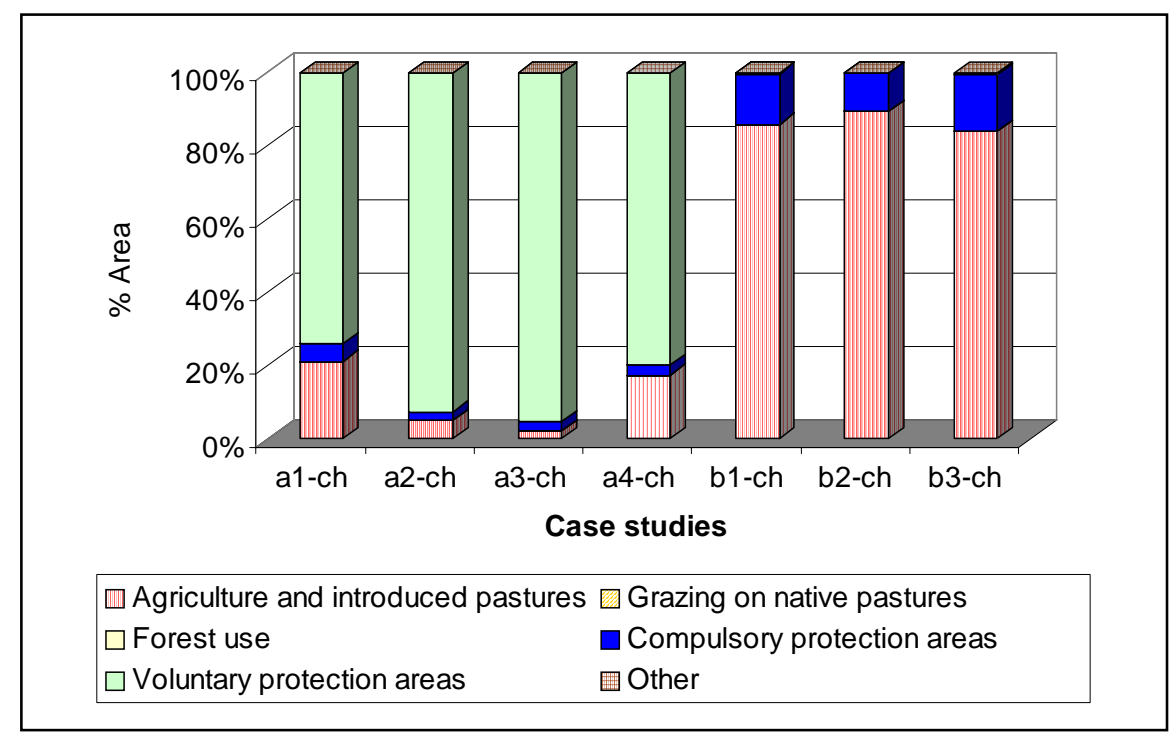

Source: Case study data

Table 40: Surfaces (ha) of proposed land-use categories in the holdings of the Chiquitano Forest ecoregion

\begin{tabular}{|l|r|r|r|r|r|r|}
\hline Case study & $\begin{array}{c}\text { Agriculture } \\
\text { and } \\
\text { introduced } \\
\text { pastures }\end{array}$ & $\begin{array}{c}\text { Grazing in } \\
\text { native } \\
\text { pastures }\end{array}$ & Forest use & $\begin{array}{c}\text { Compulsory } \\
\text { protection } \\
\text { areas }\end{array}$ & $\begin{array}{c}\text { Voluntary } \\
\text { protection } \\
\text { areas }\end{array}$ & \multicolumn{1}{|c|}{ Other } \\
\hline a1-ch & 504.80 & 0 & 0 & 115.36 & $1,758.74$ & 0 \\
\hline $\mathrm{a} 2-\mathrm{ch}$ & 101.34 & 0 & 0 & 43.45 & $1,787.35$ & 0 \\
\hline $\mathrm{a} 3-\mathrm{ch}$ & 52.34 & 0 & 0 & 64.76 & $2,310.42$ & 0 \\
\hline $\mathrm{a} 4-\mathrm{ch}$ & 464.88 & 0 & 0 & 74.98 & $2,123.86$ & 0 \\
\hline $\mathrm{b} 1-\mathrm{ch}$ & $1,231.27$ & 0 & 0 & 197.48 & 0 & 5.00 \\
\hline $\mathrm{b} 2-\mathrm{ch}$ & $9,277.93$ & 0 & 0 & $1,081.64$ & 0 & 10.00 \\
\hline $\mathrm{b} 3-\mathrm{ch}$ & 828.30 & 0 & 0 & 153.02 & 0 & 4.00 \\
\hline
\end{tabular}

\subsubsection{Land use plans in holdings with characteristics of the ecoregions Chiquitano Forest and Cerrado}

In general, the results of the land-use planning indicate a strong landowners' preference to use open areas (Cerrado and Flooded Savannas) for cattle ranching, showing that natural grassland is the main source of food for the extensive livestock, although the quality of vegetal species is poor. 
The landowners of the holdings a5-ch-ce, a6-ch-ce and a7-ch-ce have selected a land-use design in which open areas are used for cattle grazing (see figure 47). As a main measure of improvement, grasslands were divided into plots in order to carry out rotation of pastures and controlled grazing. With the exception of the proprietor of holding a6-ch-ce, who set aside open areas for conservation, the other owners (a5-ch-ce and a7-ce-ch) have decided to establish of private reserves in forested areas, in addition, they have reserved some forest plots for domestic use. Thereby the amount of planned forest conversion is small.

The impact of these land-use designs on the biodiversity will not be negative. One advantage is that there are only few changes in natural areas (land conversion) which means smaller negative effects on biodiversity; beyond, the strict organisation of grazing could prevent the overuse of natural grasslands. However, this land-use model may face some disadvantages: first, the threat of occasional incursion of cattle into the protected areas, in particular considering that the proposed reserves are within a context where cattle ranching is carried out everywhere. Second, people from outside may hunt more easily than in forest areas because of better access. Under these circumstances, a control of hunting could be the best measure to enhance the protection of wildlife, but in these actions the neighbours of the holdings must be involved, aiming for a social sustainable process of conservation.

Among all landowners who accepted to establish natural reserves, the attitude of two proprietors must be highlighted. One (a6-ch-ce) has decided to set aside open areas for nature protection a decision that was not common among the ranch-landowners, as was explained above. Considering this attitude it was established that neither economic limitations nor the need to justify land property rights have influenced the decision of this landowner, only his appreciation for wildlife. This owner is recognised as a naturalist and conservationist in the whole municipality. He easily accepted innovative proposals to combine conservation and productive activities. In this case the owner decided to introduce a semi extensive milk production-system, which requires less use of grassland and more use of supplements.

The second landowner (a7-ch-ce) has promoted ecotourism on his land in the past few years, and he was challenged by the possibilities to get economic incomes by formalising his conservation activity (i.e. to get the legal recognition of his initiative). Although ecotourism currently seems not to be a lucrative business, future projections aim to enhance local initiatives. Recently, a Santa Cruz departmental study recommended to encourage tourism investments in the "Municipalities of Gran Chiquitania", expecting a future close relationship with Brazil, which may promote a major flow of tourists both from this and other countries. 
Figure 47: Comparison of the given land-use status in 2003 and the proposed land-use arrangement of holdings with characteristics of Chiquitano Forest and Cerrado ecoregion. Holdings: a5-ch-ce, a6-ch-ce, and a7-ch-ce

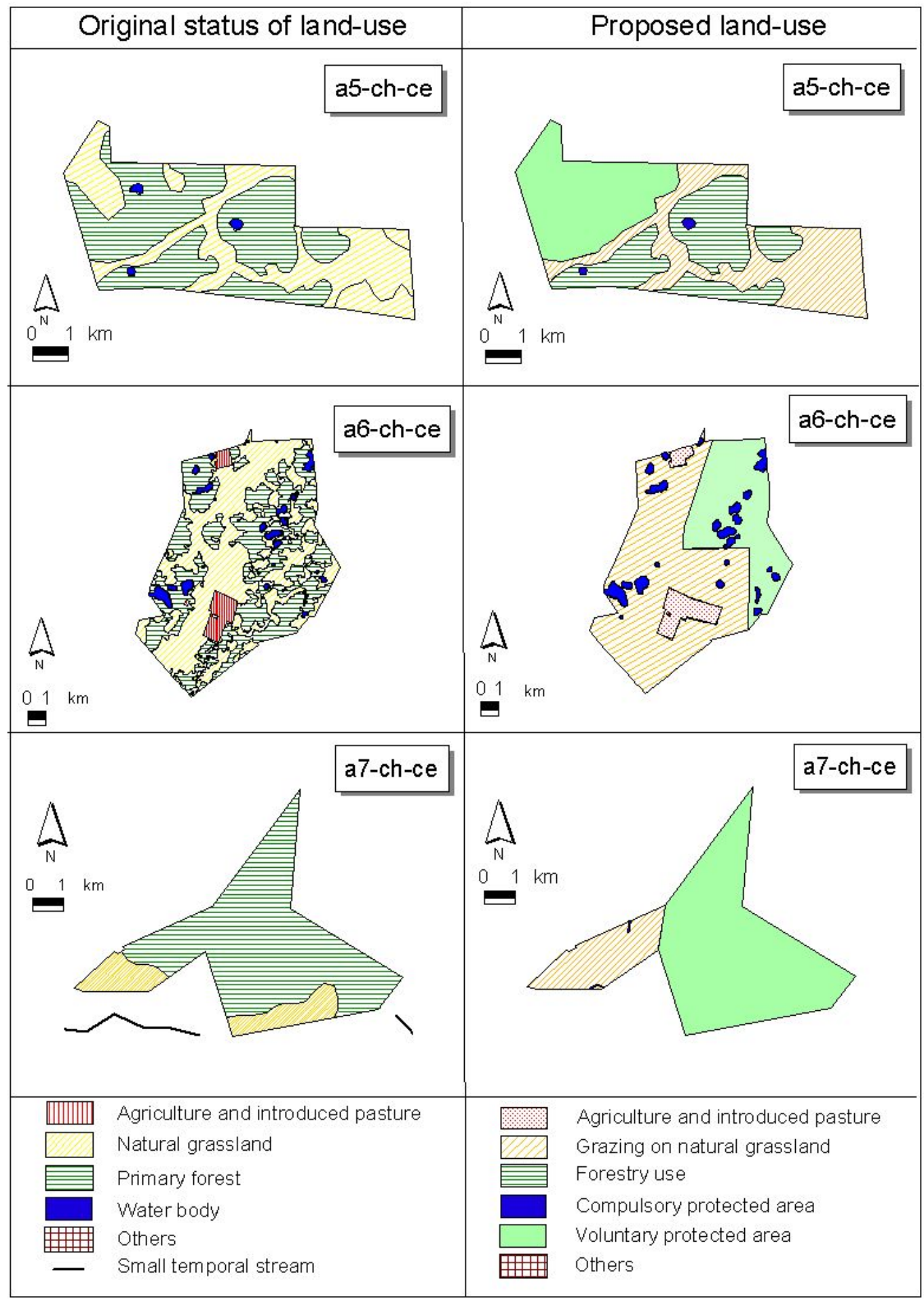

Sources: After land-use planning and stream data from Instituto Geografico Militar 1998 
Figure 48: Comparison of the given land-use status in 2003 and the proposed land-use arrangement of holdings with characteristics of Chiquitano Forest and Cerrado ecoregion. Holdings: b4-ch-ce, b5-ch-ce, and b6-ch-ce

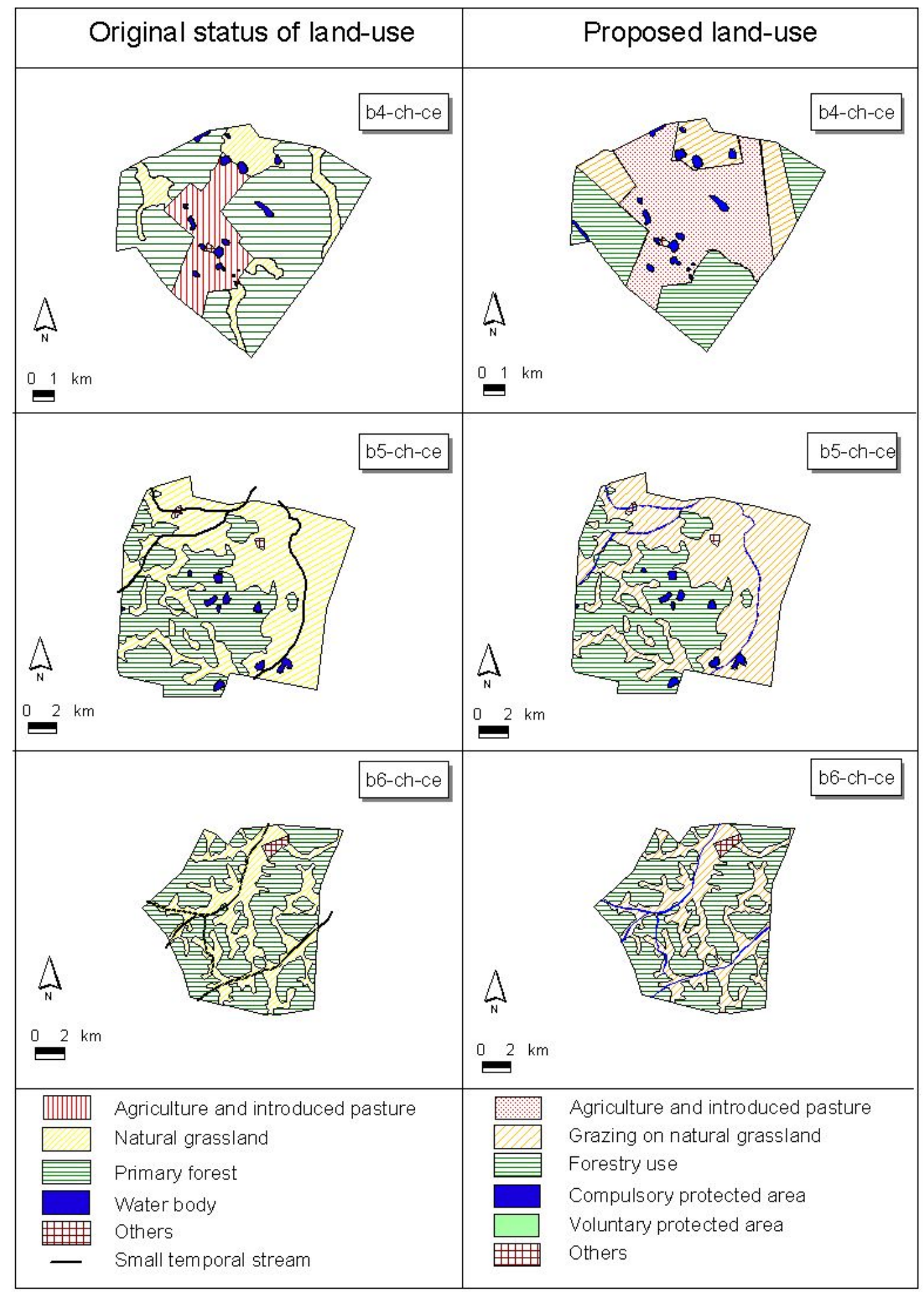

Sources: After land-use planning and stream data from Instituto Geografico Militar 1998 
Figure 49: Per cent distribution of proposed land-use categories in holdings with characteristics of the ecoregions Chiquitano Forest and Cerrado

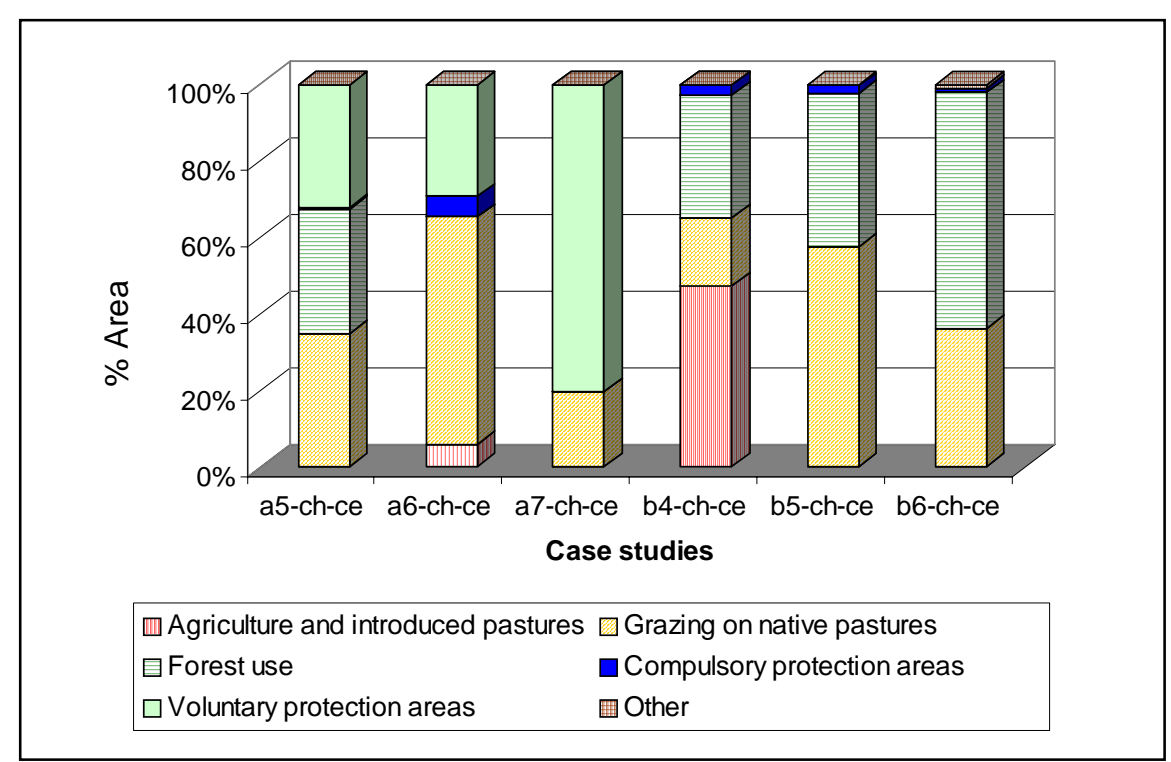

Source: Case study data

Table 41: Surfaces (ha) of proposed land-use categories in holdings with characteristics of the ecoregions Chiquitano Forest and Cerrado

\begin{tabular}{|l|r|r|r|r|r|r|}
\hline Case study & $\begin{array}{c}\text { Agriculture } \\
\text { and } \\
\text { introduced } \\
\text { pastures }\end{array}$ & $\begin{array}{c}\text { Grazing in } \\
\text { native } \\
\text { pastures }\end{array}$ & Forest use & $\begin{array}{c}\text { Compulsory } \\
\text { protection } \\
\text { areas }\end{array}$ & $\begin{array}{c}\text { Voluntary } \\
\text { protection } \\
\text { areas }\end{array}$ & Other \\
\hline a5-ch-ce & 0 & 965.75 & 901.40 & 17.39 & 889.46 & 0 \\
\hline a6-ch-ce & 538.74 & $5,506.30$ & 0 & 496.32 & $2,703.82$ & 3.99 \\
\hline a7-ch-ce & 0 & 526.24 & 0 & 4.30 & $2,145.99$ & 0 \\
\hline b4-ch-ce & $3,417.09$ & $1,287.07$ & $2,317.50$ & 178.29 & 0 & 13.40 \\
\hline b5-ch-ce & 0 & $10,222.16$ & $7,117.97$ & 374.28 & 0 & 69.37 \\
\hline b6-ch-ce & 0 & $4,301.05$ & $7,375.38$ & 114.86 & 0 & 134.28 \\
\hline \multicolumn{7}{c}{ Source: Case study data } \\
\hline
\end{tabular}

The proprietors of the holdings b4-ch-ce, b5-ch-ce and b6-ch-ce, who did not establish private reserves, have selected land-use designs that give priority to extensive cattle production (see schemes of figure 48 and 49). All open areas will be used for grazing but only small areas will suffer change due to conversion from natural grassland to exotic grassland, because of the high cost of this task. Forest areas will remain as areas for domestic use, but it is highly probable that these areas will be used for grazing too. It can be seen that, in general, the current form of use will stay the same with only little variations. The establishment of fences to divide the whole area in grazing plots is the unique planned measure to conserve and protect the pastures for livestock.

The mentioned systems may softly affect biodiversity if the cattle-surface relation is controlled as well as hunting and fire practices. Currently there are no studies that indicate 
which amount of cattle will be the best to maintain a sustainable livestock activity in this ecoregion taking into consideration the preservation of wild species. According to the landowners that have participated in this study low cattle-surface relation may not disturb biodiversity. This hypothesis should be tested in future researches.

\subsubsection{Land use plans in the ecoregion of the Amazon Flooded Savanna}

Land-use arrangements in this ecoregion give priority to extensive livestock due to their low cost and adaptability to these conditions. Figure 50 shows the shapes of land-use design of holdings a8-sa and b7-sa; this preference is common in the majority of flooded open areas in the lowlands of Bolivia (Ibisch et al. 2004a).

On these ranches (a8-sa and b7-sa), grazing has to be adjusted to the water dynamics. Thus, in the dry season cattle will graze near lagoons and streams because of water scarcity, while in the rainy season the temporal flooding that characterised this ecoregion, will push cattle to upper areas and forest isles. Under these conditions, attempts to establish plots for grazing in order to take others out of the cattle use likely will not be effective.

Little conversion of natural areas into agricultural lands is planned (see figures 50 and 51). In one of the two studied holdings (a8-sa), most of the forest areas were set aside to establish a natural reserve and the rest of the forest (mainly palm forest) will be used for domestic necessities. In the other holding (b7-sa), forest areas will be used for both grazing and domestic consume. Because of the small amount of commercial timber species, large-scale logging won't be undertaken in neither of both holdings.

Compulsory protected areas in the proposed plans will cover buffers along streams and lagoons but the total surface of these zones will remain small as in the other holdings (see figure 51). Cattle movement could affect these areas, in particular in the dry season when cattle tend to stay near water bodies.

The presented land-use arrangements seem to have a low impact on biodiversity, if hunting and fire practices are controlled. In addition, practices to conserve the grassland could indirectly improve biodiversity, in particular the measures that avoid (a) the overuse of the natural grasses (grazing rotational practices considering the flooded phenomenon), (b) the degradation of natural grasses due to trampling (especially after flooding), and that include (c) the control of the cattle-surface relationship. 
Figure 50: Comparison of the given land-use status in 2003 and the proposed land-use arrangement of holdings of Flooded Amazon Savanna ecoregion

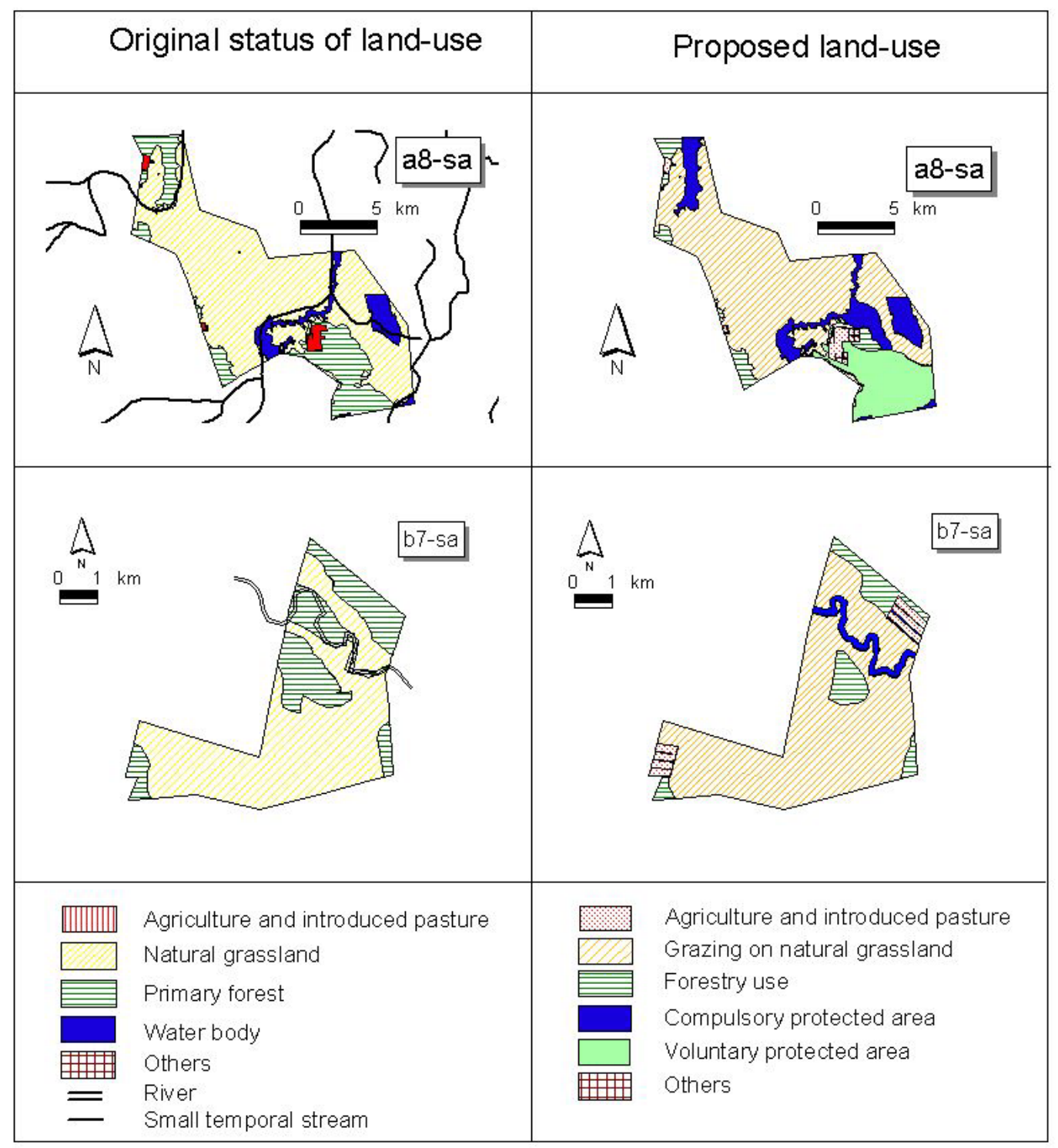

Sources: After land-use planning and stream data from Instituto Geografico Militar 1998

The proprietors of these holdings do not seem depend on the ranch revenues. They expressed that rents of cattle activities do not outstrip the costs for production and maintenance of these farms. Especially, the distant location of these holdings prevents the intensive use of these areas due to the expensive costs of transport and communication. These conditions predispose proprietors to consider other sources of profit. One of them could be ecotourism combined with conservation. The good conservation status of these areas and the location near the Noel Kempff National Park represents an important advantage for these holdings that could be used to improve tourism attraction. However, this activity requires also economic improvement. 
Concerning the land situation, these last proprietors do not have land titles, like the majority of the studied landowners, but they will not have problems to justify their land property rights, because they have amounts of cattle large enough to show the use of the land.

Figure 51: Per cent distribution of proposed land-use categories in holdings of the ecoregion of the Flooded Amazon Savanna

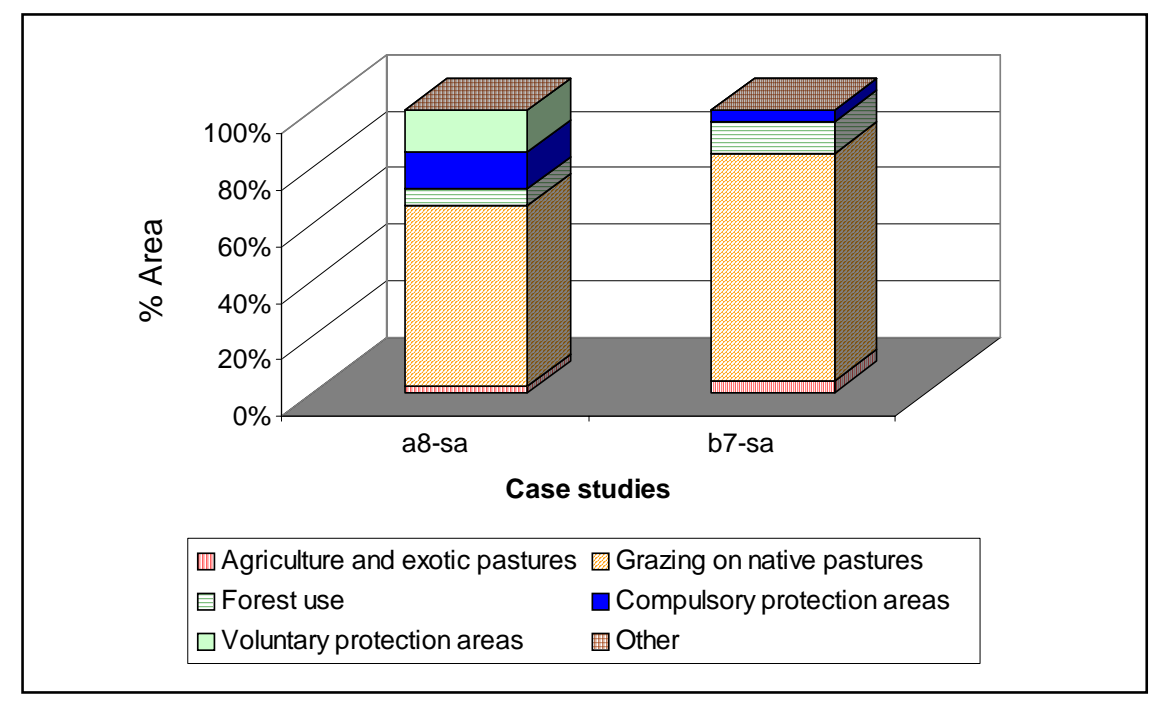

Source: Case study data

Table 42: Surfaces (ha) of proposed land-use categories in holdings of Flooded Amazon Savanna ecoregion

\begin{tabular}{|l|r|r|r|r|r|r|}
\hline Case study & $\begin{array}{c}\text { Agriculture } \\
\text { and exotic } \\
\text { pastures }\end{array}$ & $\begin{array}{c}\text { Grazing in } \\
\text { native } \\
\text { pastures }\end{array}$ & Forest use & $\begin{array}{c}\text { Compulsory } \\
\text { protection } \\
\text { areas }\end{array}$ & $\begin{array}{c}\text { Voluntary } \\
\text { protection } \\
\text { areas }\end{array}$ & \multicolumn{1}{|c|}{ Other } \\
\hline a8-sa & 335.46 & $8,976.93$ & 774.13 & $1,812.77$ & $2,073.87$ & 12.76 \\
\hline $\mathrm{b} 7-\mathrm{sa}$ & 104.4 & $1,769.77$ & 255.21 & 89.72 & 0 & 0 \\
\hline
\end{tabular}

Source: Case study data

\subsubsection{Management plan designs for "Voluntary protected areas"}

The parts of the selected holdings declared as "voluntary protected land" that were set aside for wildlife development require guidelines for conservation activities. For this reason, management plans were elaborated by an interdisciplinary team, according to the norms of the forestry low.

A summary of these plans is given in table 43, including the following information: (a) the description of the biological values that will be protected, (b) the period of voluntary 
protection, and (c) the description of the management activities. The Forestry Superintendence is in charge of the approval of the private natural reserve. The governmental recognition of a private reserve theoretically gives some benefits, like land tax exception and legal security of land property.

Most of the proposed natural private reserves are located in the area of the Chiquitano Forest, in order to protect the typical fauna and flora of this ecosystem (see table 44). In particular the maintenance of the forest cover that contributes to stopping of the forest fragmentation is one of the major benefits of these reserves. Features of "the Cerrado" are protected in two landholdings, but only in one of them (a6-ch-ce) a significant surface of this ecoregion is covered. In the ecoregion of the Flooded Amazon Savannas, a private reserve protects an Amazon Forest plot its main biological values to protect should be the major mammals of the region. The only problem is that these animals use the flooded savannas as their main habitat and not the forest area. But the open areas are preferred to set aside for livestock activities.

The fauna and flora of those reserves will face further threats from the outside such as uncontrolled hunting and fire. Therefore, the measures to protect the biodiversity of these holdings should involve their neighbours.

In all of these "private natural reserves", the owners determined 10 years as voluntary protection period; this time is the minimum one established by the law. In terms of protection needs, this time is very short. This selection logically reflects that landowners first of all use the protection activities to probe the benefits and then, according to the results they, will continue or stop this initiative.

General recommendations for management, shown in the table 43, express the minimal intention to generate more cost for landowners. Therefore, simple practices as the delimitation of the areas, the control of fire, hunting and grazing may enhance the protection and thus the value of biodiversity of those areas. 
Table 43: Summary of the proposed management plans of natural private reserves

\begin{tabular}{|c|c|c|c|c|}
\hline $\begin{array}{l}\text { Case } \\
\text { study }\end{array}$ & $\begin{array}{l}\text { Voluntary } \\
\text { period of } \\
\text { protection }\end{array}$ & $\begin{array}{c}\text { Area } \\
\text { (ha) } / \% \\
\text { Holding } \\
\text { area }\end{array}$ & Features to protect & $\begin{array}{l}\text { Recommendation } \\
\text { for management }\end{array}$ \\
\hline a1-ch & 10 years & $\begin{array}{r}1,808,43 \\
76,01 \%\end{array}$ & \multirow{4}{*}{$\begin{array}{l}\text { FLORA: Chiquitano Forest: Tabebuia impetiginosa (tajibo rosado), Schinopsis } \\
\text { brasiliensis (soto), Astronium urundeuva (cuchi), Anadenanthera colubrina } \\
\text { (curupau). FAUNA: More than } 26 \text { species of mammals, for instance: Callithrix } \\
\text { argentata (mono leoncito), Cerdocyon thous (zorro patas negras) Procyon } \\
\text { cancrivorus (osito lavador), Leopardus pardalis (ocelote), Mazama americana } \\
\text { (huaso), Tayassu tajacu (taitetú). More than } 88 \text { birds such as: Pyrrhura molinae } \\
\text { (lora cola roja), Hemithraupis guira (fruterito), Ara auricollis (parabachi cuello } \\
\text { amarillo), Aratinga acuticauda (lora frente azul), Aratinga aurea (lora frente } \\
\text { amarilla), Pionus maximiliani (loro chuto), Amazona festiva (loro galano), and } \\
\text { Crax fasciolata (pava pintada). Recuperation of faunal populations, } \\
\text { maintenance of Chiquitano Forest connectivity. }\end{array}$} & \multirow{4}{*}{$\begin{array}{l}\text { - Delimitation of } \\
\text { private reserve } \\
\text { - Labelling } \\
\text { - Establishment of } \\
\text { fire barriers } \\
\text { - Hunting control } \\
\text { - Grazing control }\end{array}$} \\
\hline a2-ch & 10 years & $\begin{array}{r}1,823,33 \\
94,36 \%\end{array}$ & & \\
\hline a3-ch & 10 years & $\begin{array}{r}2,369.02 \\
97.59 \% \\
\end{array}$ & & \\
\hline a4-ch & 10 years & $\begin{array}{r}2,157.95 \\
81.01 \%\end{array}$ & & \\
\hline a5-ch-ce & 10 years & $\begin{array}{r}895.82 \\
32.76 \%\end{array}$ & $\begin{array}{l}\text { FLORA: Chiquitano Forest: Tabebuia impetiginosa (tajibo rosado), Schinopsis } \\
\text { brasiliensis (soto), Astronium urundeuva (cuchi), Anadenanthera colubrina } \\
\text { (curupau). Cerrado, trees and shrubs: Qualea multiflora, (sorioco), Curatella } \\
\text { americana (Chaaco), Genipa americana (bi), Tabebuia aurea (alcornoque, } \\
\text { paratodo); native herbaceous: Vernonia patens, Sebastiana hispida, Axonopus } \\
\text { siccus y Chamaecrista nictitans. FAUNA: More than } 26 \text { species of mammals, for } \\
\text { instance: Callithrix argentata (mono leoncito), Cerdocyon thous (zorro patas } \\
\text { negras) Procyon cancrivorus (osito lavador), Leopardus pardalis (ocelote), } \\
\text { Mazama americana (huaso), Tayassu tajacu (taitetú). More than } 88 \text { birds, for } \\
\text { instance: Pyrrhura molinae (lora cola roja ), Hemithraupis guira (fruterito), Ara } \\
\text { auricollis (parabachi cuello amarillo), Aratinga acuticauda (lora frente azul), } \\
\text { Aratinga aurea (lora frente amarilla), Pionus maximiliani (loro chuto), Amazona } \\
\text { festiva (loro galano), and Crax fasciolata (pava pintada). Recuperation of faunal } \\
\text { populations, maintenance of Chiquitano Forest connectivity. }\end{array}$ & $\begin{array}{l}\text { - Delimitation of } \\
\text { private reserve } \\
\text { - Labelling } \\
\text { - Establishment of } \\
\text { fire barriers } \\
\text { - Hunting control } \\
\text { - Grazing Control }\end{array}$ \\
\hline a6-ch-ce & 10 years & $\begin{array}{r}2,703.82 \\
29.23 \%\end{array}$ & $\begin{array}{l}\text { FLORA: Cerrado, trees and shrubs: Qualea multiflora, (sorioco), Curatella } \\
\text { americana (Chaaco), Genipa americana (bi), Tabebuia aurea (alcornoque, } \\
\text { paratodo); native herbaceous: Vernonia patens, Sebastiana hispida, Axonopus } \\
\text { siccus y Chamaecrista nictitans. Flooded Savanna: Curatella americana } \\
\text { (Chaaco), Tabebuia aurea (alcornoque, paratodo), Tabebuia impetiginosa (tajibo } \\
\text { rosado), Physocalymma scaberrimum (coloradillo), Leersia hexandra, Paspalum } \\
\text { virgatum, Hymenachne amplexicaule, Axonopus fissifolius. } \\
\text { FAUNA: Almost } 27 \text { species of mammals, for example: Callithrix argentata } \\
\text { (mono leoncito), Dasypus novemcinctus (tatu), Cerdocyon thous (zorro patas } \\
\text { negras), Pseudalopex gymnocercus (zorro de pampas), Procyon cancrivorus } \\
\text { (osito lavador), Mazama gouazoubira (urina), Dasyprocta variegata (jochi } \\
\text { colorao). More than } 165 \text { birds, for example: Vireo olivaceus, Brotogeris chiriri, } \\
\text { Phalacrocorax brasilianus (pato cuervo), Egretta thula (garcita blanca), Ajaia } \\
\text { ajaja (garza espátula), Jabiru mycteria (bato). Recuperation of faunal } \\
\text { populations, maintenance of Chiquitano Forest connectivity. }\end{array}$ & $\begin{array}{l}\text { - Delimitation of } \\
\text { private reserve } \\
\text { - Labelling } \\
\text { - Establishment of } \\
\text { fire barriers } \\
\text { - Hunting control } \\
\text { - Grazing Control }\end{array}$ \\
\hline A7-ch-ce & 10 years & $\begin{array}{r}2,146.00 \\
80.16 \%\end{array}$ & $\begin{array}{l}\text { FLORA: Chiquitano Forest: Tabebuia impetiginosa (tajibo rosado), Schinopsis } \\
\text { brasiliensis (soto), Astronium urundeuva (cuchi), Anadenanthera colubrina } \\
\text { (curupau) } \\
\text { FAUNA: More than } 26 \text { species of mammals, for instance: Callithrix argentata } \\
\text { (mono leoncito), Cerdocyon thous (zorro patas negras) Procyon cancrivorus } \\
\text { (osito lavador), Leopardus pardalis (ocelote), Mazama americana (huaso), } \\
\text { Tayassu tajacu (taitetú). More than } 88 \text { birds such as: Pyrrhura molinae (lora cola } \\
\text { roja), Hemithraupis guira (fruterito), Ara auricollis (parabachi cuello amarillo), } \\
\text { Aratinga acuticauda (lora frente azul), Aratinga aurea (lora frente amarilla), } \\
\text { Pionus maximiliani (loro chuto), Amazona festiva (loro galano), and Crax } \\
\text { fasciolata (pava pintada). Recuperation of faunal populations, maintenance of } \\
\text { Chiquitano Forest connectivity. }\end{array}$ & $\begin{array}{l}\text { - Delimitation of } \\
\text { private reserve } \\
\text { - Labelling } \\
\text { - Establishment of } \\
\text { fire barriers } \\
\text { - Hunting control } \\
\text { - Grazing Control }\end{array}$ \\
\hline A8-sa & 10 years & $\begin{array}{r}2,073.87 \\
14.82 \%\end{array}$ & $\begin{array}{l}\text { FLORA: Flooded savanna (e.g. Tabebuia impetiginosa), Amazon Palm forest } \\
\text { (e.g. Mauritia flexuosa), Forest island (Mauritiella armata, Cassia alata) } \\
\text { FAUNA: Mammals: Chrysocyon brachyurus (Borochi), Ozotoceros bezoarticus } \\
\text { (Gama), Blastocerus dichotomus (Ciervo de los pantanos), Birds: Ara ararauna, } \\
\text { Amazonetta brasiliensis (Patito), Cairina moschata (Pato negro), Dendrocygna } \\
\text { bicolor (Pato putiri), Chauna torquata (Tapacare), Caprimulgus cf rufus } \\
\text { (Cuyabo) Recuperation of faunal populations, maintenance of Chiquitano } \\
\text { Forest connectivity }\end{array}$ & $\begin{array}{l}\text { - Delimitation of } \\
\text { private reserve } \\
\text { - Labelling } \\
\text { - Establishment of } \\
\text { fire barriers } \\
\text { - Hunting control } \\
\text { - Grazing Control }\end{array}$ \\
\hline
\end{tabular}

Source: Proposed management plans of natural private reserves carried out by MHNNKM, as part of the project: "POP and RPPN implementation in cattle ranches of Chiquitania region" (years 2002 and 2003). 


\subsubsection{Discussion about the landowners' predisposition to set aside areas for biodiversity}

The results of the last chapter give a basis for a characterisation of different types of landowners depending on their motivation to contribute to conservation biodiversity in the context of the study.

Three groups of owners could be identified among the case studies: (a) proprietors who set aside areas for biodiversity in order to contribute to conservation, (b) owners who accepted reserves in order to test their benefit looking for a viable and profitable land-use of non exploited land, and (c) landowners who did not want to establish natural private reserves.

The first group of owners has shown a visible interest and readiness for compromises to protect the wildlife of their holdings; there does not seem to exist a relationship between this attitude and other factors. It is purely a natural inclination for nature. However, some characteristics are common in the two registered cases of this study. First, they are living on their properties and carrying out production activities; second, they come originally from this region and they prefer to live in their home-region although they would have the possibilities to live in big cities. The number of proprietors with this inclination does not seem to be high (two of fifteen cases in this study), nevertheless, they could be the key-group to implement pilot-models of land-use that involve conservation of biodiversity and thus they could contribute to widespread acknowledgement of the importance of conservation among their neighbours. Most of the institutions that are currently promoting conservation outside of National Protected Areas are taking this type of proprietors in the first stages of their work (Choquehuanca 2001, Choquehuanca 2003, ELI et al. 2003, PROMETA 2002).

The second group comprises owners who have not yet exploited their lands (mainly located in forested areas) because of the lack of economic resources. These proprietors are also concerned about the process of the land tenure cadastre, which is evaluating the legal use of the land in Bolivia. As a consequence, they are looking for chances to avoid land reversion. Land-use plans that allow the gradual conversion is a less damaging and more common option to show the legal use of soils, but this means a gradual destruction of natural areas. For these people the establishment of private reserves could open an opportunity to get a proof of the legal use without the necessity to destroy the forest and its biodiversity, but the multiple severe legal prerequisites required by the government limit this chance. Thus, changes in the land policies are needed to incorporate this group in the conservation process (ELI et al. 2003). 
The third group of landowners corresponds to people who have more economic possibilities but they are not interested in setting aside areas for biodiversity conservation because they promote the intention that the land should be used for production activities. This group is improving the economical growth in this region and therefore has a significant social influence: their attitude is difficult to change without economic incentives. In these cases, the enforcement of compulsory protected areas may represent the more realistic strategy to promote private land preservation (Choquehuanca 2003).

In general, the results of the case study indicate that most proprietors of the study region will not accept that large parts of their holdings remain untouched for biodiversity conservation, although biological studies determine that these areas a have priority for conservation. Therefore, a feasible strategy to promote conservation is to combine in the land-use arrangements pure conservation (probably in small areas) with productive activities that will not harm the wild zones; in this way ecological production of cattle and controlled logging would be some possible measures to be explored. In addition, the promotion of indirect use of the intact areas (for example through ecotourism) as well as direct possibilities of use (for example the use of non-timber products) must be discussed in future studies.

Proprietors have demonstrated that they sometimes have a different opinion about what to set aside for conservation than do scientists. For instance, one proprietor preferred to conserve forest in an ecoregion in which - following the opinions of scientists - open areas should be protected due to their importance to the mammals of that region. In this case, the optimum arrangement has to be determined through a dialogue between scientist and the landowner. This study established that participatory land-use planning is the best tool to arrange adequately the different components of the holdings. In this purpose, interdisciplinary work allows the detection of the best models for production and conservation.

\subsubsection{Evaluation of the implementation of land-use and management plans of private natural reserves}

Once land-use and management plans of private reserves have been elaborated, owners have to present them to the government to achieve their approval. Only then these plans can be carried out in the holdings.

To get an integral understanding of the private land conservation process, monitoring of the procedures and legal formalities required for land-use approval has to be carried out during 
one year after the land planning, both to systematise administrative-legal problems and to control the enforcement of the proposed land-use designs (see table 44).

Land-use plans have to be approved by the Agrarian Superintendence, while management plans have to be approved by the Forestry Superintendence. Besides, landowners have to fulfil some other legal requirements, in particular the presentation of land titles.

Through the monitoring it was established on the one hand that only three of the eight landowners who had initially accepted to set aside areas for natural reserves, achieved the approval of their land-use plans by the government. Until the end of 2003, none of these landowners could obtain the approval of the management plans of their reserves (table 44). The main reason for these results is the lack of land titles, which is a strong and difficult requirement to fulfil. Other reasons that stopped this process were the low interest of landowners to follow long and bureaucratic procedures and the existence of a land purchase demand by investors from Brazil, who were looking for properties in the study zone, in particular near the main roads expecting an economical boom in this area through the future establishment of a bi-oceanic road. Thus, an owner purchased his property due to a good economic offer instead of following the idea of private land conservation.

On the other hand, the proprietors who did not want to establish private natural reserves (group B), had no difficulties in getting the approval of their land-use plans, although most of them did not have land titles. This fact reflects the unfair influence of land and environmental policies. The correspondent analysis of the mentioned fact is presented in the next chapter. 
Table 44: Result of the legal process of governmental recognition of proposed land-use and management plans

\begin{tabular}{|c|c|c|c|c|c|}
\hline $\begin{array}{l}\text { Case } \\
\text { study }\end{array}$ & $\begin{array}{l}\text { Agreement to } \\
\text { establish } \\
\text { private } \\
\text { reserves }\end{array}$ & $\begin{array}{l}\text { Implementation } \\
\text { of the proposed } \\
\text { land-use plan }\end{array}$ & Reasons & $\begin{array}{c}\text { Implementation of } \\
\text { the proposed } \\
\text { private natural } \\
\text { reserve }\end{array}$ & Reasons \\
\hline A1-ch & Yes & No & Lack of land title & No & Lack of land title \\
\hline A2-ch & Yes & No & $\begin{array}{c}\text { Purchase of } \\
\text { holding }\end{array}$ & No & $\begin{array}{c}\text { Purchase of } \\
\text { holding }\end{array}$ \\
\hline A3-ch & Yes & No & Lack of land title & No & Lack of land title \\
\hline A4-ch & Yes & No & Lack of land title & No & Lack of land title \\
\hline A5-ch-ce & Yes & No & $\begin{array}{l}\text { Lack of interest to } \\
\text { continue with the } \\
\text { planning }\end{array}$ & No & $\begin{array}{l}\text { Lack of interest to } \\
\text { continue with the } \\
\text { planning }\end{array}$ \\
\hline A6-ch-ce & Yes & Yes & & Process started & \\
\hline A7-ch-ce & Yes & Yes & & No & Lack of land title \\
\hline A8-sa & No & Yes & & Process started & \\
\hline B1-ch & No & Yes & & \multirow{7}{*}{\multicolumn{2}{|c|}{ Not included in the land-use plan }} \\
\hline B2-ch & No & Yes & & & \\
\hline B3-ch & No & Yes & & & \\
\hline B4-ch-ce & No & Yes & & & \\
\hline B5-ch-ce & No & Yes & & & \\
\hline B6-ch-ce & No & Yes & & & \\
\hline B7-sa & No & Yes & & & \\
\hline
\end{tabular}

\subsubsection{Identified factors that impede the establishment of private natural reserves}

\subsubsection{Land tenure situation}

The disorganised situation of land tenure is the main legal factor preventing the establishment of the proposed reserves. Since land titles are the main requirement for private land conservation and most proprietors do still not have them, they are not allowed to participate in biodiversity conservation.

The majority of landowners in the region received their land from the government in the last decades under the condition to work and invest in production activities. Because of failures in land policies and the governmental administration, land titling and control of the legal use of the land have not been carried out for a long time; as a consequence, conflicts have emerged, for instance, the overlapping of ownerships, and no recognition of indigenous territories. This situation affects as well the study zone as the majority of rural areas in Bolivia. 
Since 1996, the process of land tenure regularisation and land cadastre has been undertaken in order to solve the irregular situation of properties. The main task of this process is the evaluation of social and economic functions (SEF) of rural lands. The SEF is the main precondition to own land; it establishes that the land has to be used for subsistence farming, large-scale production and conservation, in order to avoid land accumulation for illegal traffic. However, this process is being accomplished very slowly due to bureaucratic procedures. Thus, in the study zone, by the end of 2003, not a single landowner has managed to obtain his land title.

The establishment of Natural Heritage Private Reserves (NHPR) is currently the most important legal way to conduct conservation on private land fulfilling the legal requirements (i.e. the SEF). The major constraint is that land titles are required in this process. The majority of proprietors are still undergoing the titling process and cannot establish private reserves.

In conclusion, the legal rules are pushing landowners to reject wildlife protection and to choose exclusively agricultural systems that destroy valuable biological areas. Forestry use in private holdings faces the same legal constrains.

\subsubsection{Lack of incentives and economic rents}

The private land conservation has no effective incentives in Bolivia. Among the benefits of establishing private reserves, the recognition of land property rights and the juridical security are the most frequently expected advantages by the owners, according to the outcomes of the research. However, because of the lack of land titles the owners cannot get the approval of their reserves and consequently they cannot get the juridical protection. The other given benefit: the land tax exoneration is little attractive given the low cost of it and the weak system of tax control.

In this situation, there are no desirable incentives to offer to the majority of proprietors in the study region, since they are looking for alternatives of land-use that could be compatible with the land policies.

Although the necessity to demonstrate legal land rights and adequate land-use has increased the interest in private reserves, in the majority of cases it is a temporal motivation to gain time waiting for future economic alternatives. In this context, if private conservation does not offer economic rents or as a minimum the opportunity cost for land-use, then private reserves may last short periods of time only. 
Economic compensation or subsidies for private land conservation seem to be the best way to promote private conservation, but there are only remote possibilities to implement sustainable systems of compensation in Bolivia due to poverty. In addition, the experiences in Latin America show that direct economic incentives have not been perfect to improve conservation (see chapter 2.3.).

\subsubsection{Bureaucratic technical and legal procedures}

The administrative and legal process of establishing a private reserve is based on a long and bureaucratic procedure that disincentives private initiatives of conservation.

The process is characterised by long periods of waiting and significant costs, which include the carrying out of land-use planning and management plans. This is another reason that impede the establishment of private reserves.

The governmental organisations in charge of carrying out these procedures present on the one hand several limitations and on the other hand a lack of coordination. Concerning the limitations, it can be observed that in the Forest and Agrarian Superintendence there is little personnel available to control and revise technical and legal documents. In addition, the centralised structure determines a waste of long periods of time waiting for decision from the central offices located in the capital far from the study zone, even though some technical or administrative resolutions could be taken in the local offices. With regard to the problems of coordination, several institutions (the Forestry Superintendence, the Agrarian Superintendence, the National Office of land (INRA)) are involved in the approval of private reserves, so that proprietors are exposed in some cases to a duplication of requirements and waiting time.

Under these circumstances, a privileged treatment for proprietors who want to set aside areas for biodiversity conservation could be a major incentive, as well as a general decentralisation of the process.

\subsubsection{Restrictions on land use in private reserves}

The establishment of private reserves determines a strong restriction (see 2.3.1.b) on land use. This is very favourable for biodiversity development. Nevertheless, from an economic point of view, the imposition of strict limitations might be another obstacle considering that a lot of owners have to spend economic resources to maintain the conservation instead of gaining money through it. 
Thus the redefinition of restrictions for private reserves and the creation of categories that allow more possible combinations between production and conservation may enhance the participation of owners who want to take part in conservation but reject it because of the strong legal rules and compromises.

\subsubsection{Weak institutional capacity for the enforcement of private conservation norms}

The enforcement of environmental laws in Bolivia represents the main institutional problem for conservation issues. Institutions in charge of regulating and monitoring the fulfilment of legal environmental rules have several weaknesses (for instance, lack of economic resources, lack of knowledge about private conservation, etc.) to achieve their duties.

In the case of private land conservation, landowners who participate in the first attempts have become disappointed because of the lack of governmental support, in particular when their reserves were affected by external agents like hunters, loggers, fire from neighbourhoods. With the beginning of this century, the invasions of lands by colonists calling for fair free distribution of land have increased. This is probably the main threat that concerns the proprietors of private reserves. In cases of invasion, governmental institutions have had a lot of difficulties to control the invaders and in some cases they could not even intervene due to the social and political pressures. Currently, the first private reserve established in Bolivia in 2001 (property "El Porvenir” located in Santa Cruz) is occupied by colonists. 


\subsection{Recommended measures and strategies to promote private land conservation}

\subsubsection{Private conservation encouraged by incentives}

A great contribution of private conservation will be possible only when it is encouraged through effective incentives. For this reason, in this section some incentives, though elaborated mainly for the specific circumstances/characteristics of the study zone, are proposed and discussed. Nevertheless, the identification of the best incentives requires more research and pilot experiments.

\subsubsection{Current viable incentives}

\section{Technical interdisciplinary support}

The close collaboration with landowners during the course of this study allowed the direct discussion of options and visions. It has been observed that proprietors in one or the other way admit the importance of conservation in their holdings, but still most of them prefer to use their land for production.

In this context, the elaboration of a land use plan free of charge, providing an interdisciplinary team of technicians that benefited the landowners, namely technical support in the land use planning process, was an effective instrument to inform proprietors about the profitable and sustainable use of the holding's resources. In some cases, this dialogue could change the destructive attitude. Therefore, this strategy should be further developed and spread in order to support the creation of more protected areas on private land, which should be appropriately combined with other sustainable alternatives like forestry, agroforestry and silvo-pastoral production systems.

NGOs and the governmental institutions would provide the mentioned technical support. Experiences in private conservation in countries like Costa Rica, Mexico and Paraguay coincidently show that technical and legal support are interesting incentives for proprietors in rural areas. Mainly NGOs have provided this type of incentive, which is cheap and represents a way that multiplies the possible uses of the resources, for example organic production and eco-tourism. 
Since 2002, the Bolivian NGOs FAN-Bolivia and FCBC have been carrying out pilot projects that offer land-planning support as main incentive for private conservation with effective results.

\section{Recognition and award of private conservation initiatives}

Conservation on private land, informal or based on legal norms, is expensive and difficult to carry out. Nevertheless, most of the proprietors who have accepted to participate in biodiversity conservation are not yet recognized for their efforts not only by the state but also not by the rest of the society, even though their works benefit the general environmental conditions for everyone.

According to the results of the NGO's work in Latin America and pilot experiments of private conservation in Bolivia (Choquehuanca 2003; Choquehuanca \& Eguino 2003) social recognition is an important incentive for conservation. In this study, conservationists owning land have been encouraged by the researchers' recognition of their contribution to biodiversity. In particular, the interchange of local versus scientific knowledge has enhanced the landowners' valuation of conservation.

Hence, projects and programs encouraging proprietors in different ways will enhance the adoption of conservation issues, for instance the rewarding of proprietors who show remarkable work and the diffusion of the information about this work. Thus, these proprietors will gain respect for their engagement in private land conservation and other proprietors will try to follow up and also take part in the protection of biodiversity.

Furthermore, positive effects for conservation may be expected by rewarding eco-efficient production, such as coffee production in agroforestry systems or by rewarding the ecological production of meat or sustainable logging.

\subsubsection{Incentives to be developed}

Private conservation will not be able to make a significant contribution as long as effective incentives are not developed, but this task involves more specific studies and pilot projects. In this section, incentives that could be developed in the future are enumerated as ideas for future studies. 


\section{Payment for environmental services}

Recently, payments for environmental services have been frequently mentioned as tools for conservation financing. Private land conservation researchers and institutions have discussed this economic way to get benefits for conservationists owing land. However, with the exception of Costa Rica, no other country of Latin America has achieved a similar program to directly compensate the conservation of nature. In the case of Bolivia, monetary compensations for conservation are still from being carried out considering the country's low incomes and, as a consequence, the low suitable funds for biodiversity conservation.

Payment of environmental services on local or national level would be possible if the users recognised the importance of areas providing these services (Ibisch \& Choquehuanca 2004), for instance the hydro-regulatory function of the study area. Then diffusion and education, environmental economic valuation, and political lobbying are some measures to undertake as first steps in a program for environmental compensation. The ideal achievement would be to include the costs in the national accounts and budgets.

Since the 1990s, international protocols, such as the Kyoto protocol, have opened the discussion of compensations for fixation of carbon in forest areas, aiming to reduce global warming, but disagreements are avoiding the development of this mechanism of compensation. Under the current conditions of the Kyoto protocol only forestation is supported. Proprietors of agricultural land could also benefit but currently only the early stages of this mechanism are developed and there are no programs for implementation yet.

\section{Incentives for forest reserves and forest production on private holdings}

In theory, economic direct compensation for conservation would be the best incentive, but in praxis the few undertaken experiences in Costa Rica have shown that this incentive is not perfect and sustainable (see Chapter 2.3). For this reason, economic incentives that improve the production capacity of holdings seem to be more realistic and feasible than short term direct compensations.

With regard to the study zone, the results of the ecoregional analysis (chapter 5.1.) and other land-use planning studies (PLUS, PCBC) imply that the region has a regular to high potential for forestry, therefore incentives that enforce forestry activities may significantly contribute to conservation and thus maintain connectivity. Research on the impacts of logging on Bolivian Forests has not revealed many primary negative impacts on biodiversity. The most important impact due to logging are the secondary impacts. Although the logging causes changes in the 
forest, this remains and recuperates, in some cases, very rapidly if the planning and implementation of the logging is done well" (Fredericksen 2004). In this way, the development of the following incentives is recommended:

- Tax incentives for sustainable logging in private holdings

- Support of forest management practices to enhance a rapid regeneration of wood in private reserves

\section{Support of private initiatives of eco-tourism}

Eco-tourism can also be an activity that promotes conservation on private land. There are some proprietors who certainly want to explore the possible benefits of this activity, but they need support for the construction of infrastructure and the improvement of their human resources (e.g. guides). However, the current demand for tourist services is still very low so it is recommended, as a first step, to limit the support to only a few landowners.

\subsubsection{Strategies to involve the civil society in private conservation}

\subsubsection{Joint work between the private sector and the government}

The number of private initiatives for conservation will not increase if local (municipal and departmental) and national government do not support them with adequate policies and the enforcement of laws.

For this reason the establishment of a close relationship among the entities that regulate legal procedures of private conservation, the private landowners and the conservationists' institutions, is a strategy that will help to solve the problems more easily than isolated initiatives. Thus, joint projects, specialised training, the diffusion of information and regular feedback among them are activities that could improve an efficient inter-institutional work.

In particular, training in the regulations of private land conservation for government employees, who are working in entities not related to conservation but related to land regulations and taxes, is needed because most of them are not familiar with the procedures and policies that allow owners to participate in the conservation of biodiversity.

Good synergic outcomes are expected from an inter-institutional co-operation. One such example is the inter-institutional project of two governmental institutions (SIA, SIF), two NGOs (FAN-Bolivia, FCBC) and Gabriel Rene Moreno University carried out in Chiquitania 
region. In this project, new criteria for land-use planning regulations were developed depending on the environmental conditions and conservation priorities of the area under consideration (FCBC online 2004).

\subsubsection{Strengthening of key governmental institutions}

Governmental institutions in charge of the regulation of private land conservation in Bolivia currently suffer economic and administrative restrictions which limit their capacity to enforce conservation laws and monitoring activities.

For this reason, one of the first steps to promote private conservation is also the support of these institutions in order to improve their capacities. Target groups are (a) the regulatory governmental organisations: Agrarian Superintendence (SIA), Forestry Superintendence (SIF), (b) Governmental agencies: National Service of Protected Areas (SERNAP), (c) local governments: Prefectures and Municipalities, and (d) other entities, such as the ownership registry office.

Regulatory governmental institutions have to control the enforcement of laws. The Agrarian Superintendence, in charge of controlling the land-use planning and the adequate use of soil, has shown weaknesses due to the lack of resources. For instance, in 2003, this institution had only one employee to attend the land-use planning processes of three departments. Obviously, this situation has retarded the approval of land-use plans and their monitoring. The role of the Agrarian Superintendence in the process of private conservation is vital and therefore not only economic support is urgent but also assistance to improve their functional structure. Given the fact that economic resources are limited, this institution should share its competences with local governments, in particular with municipalities.

In contrast, the Forest Superintendence has received assistance from US-projects and therefore has a very good institutional structure and some economical independence, since it gets part of the taxes of timber exploitation. Nevertheless, this institution has very few personnel assigned to attend private conservation.

The environmental law establishes that all protected areas, including the private ones, are under the control of the state and its correspondent institutions. The National Service of Protected Areas (SENAP) is responsible for the administration of protected areas, but this institution has had very little impact to help private conservation initiatives. On the one hand the SERNAP has limited resources to attend them, but on the other hand this institution did not design a clear policy about the private conservation movement. Conservation initiatives 
on private lands, whose numbers are increasing encouraged by some Bolivian environmentalists' organisations, are calling for a more active involvement of the SERNAP.

The institution in charge of the revision of property rights (INRA) can influence through its policy the people's attitudes towards either deforestation or conservation. Up to now, the land cadastre has been realized around strong social and economic pressures, thus the concepts of biodiversity conservation have practically been ignored. Because of its key-role in land tenure definition, INRA should receive support to address their procedures and actions preventing the destruction of natural areas.

The Prefectures or departmental governments, which administrate all civil matters, play a sensitive role regarding private conservation, because they guarantee the security for private ownership. However, their capacities for immediate interventions to help landowners who are affected by transgression (for example illegal hunting) are not yet effective.

Finally, the municipalities need to support their operative dependences related to the management of natural resources to introduce policies for private conservation as was mentioned in 5.3.1.3.

\subsubsection{Proactive monitoring of the process of land tenure revision}

Currently, the establishment of private conservation areas is connected to the process of land tenure revision. Land-use planning is a part of the technical evaluation of this process in order to get the governmental recognition of land property, i.e. most landowners have to obtain their land-use plans. Thus, a historical strategic moment to promote land-use systems with conservationist perspective is going on and therefore several opportunities to promote the sustainable use and conservation on private lands. However, at the same time, land planning could allow the destruction of natural values if production concepts predominate and land conversion is preferred.

Under these conditions, the monitoring of the revision process of the land rights must be done in order to avoid a negative effect on forest areas and in general on the environment. Institutions, scientists and social groups should stress the importance of areas with priority for conservation such as the study zone.

Nowadays there are high social pressures on the institutions in charge of the revision of the property rights. Several stakeholders are fighting to get more access to land but most of them are obviously not considering the biological value of those lands. Here the diffusion of 
information and permanent communication could be an effective manner to introduce the conservationists' concepts of sustainable land use.

\subsubsection{Diffusion of information about private conservation and specific education}

The most important challenge for the private conservation movement in Bolivia, in the short term, is to achieve the recognition and respect of the civil society - this involves the understanding of the benefits of natural area conservation on private properties.

It is important to remark that the landowners of private reserves are not the sole group which suffers from this lack of recognition. Also rural and indigenous communities (also private proprietors), who have been the first defenders of nature, have had to deal with juridical insecurity and absence of incentives.

Then, a second urgent task is to educate and inform about private conservation. The opportunities of a direct participation of the civil society in conservation has to be demonstrated with the purpose of involving as many Bolivian citizens as possible. The recognition of the right to conserve will set appropriate conditions for the support and the creation of incentives.

\subsection{Implications from the study for conservation policies}

\subsubsection{Suggested possible changes in the short term}

\subsubsection{Adjustments to different regulations of conservation and forest use}

Flexibility by recognition of private reserves and forest areas in private properties

According to the definition of the Forest law Regulation of Bolivia a Natural Heritage Private Reserves (private reserve) constitute a voluntary ecological servitude, settled down by the proprietor in order to conserve the ecological values or remarkable scenic beauties from the property. This definition implies that the proprietor of the land has to have land tenure rights recognised by the state. Considering that few proprietors have this requirement, conservation initiatives are prevented, affecting in particular the development of protection measures in 
areas of high biological importance for conservation that do not have formal protection of the state.

If legal dispositions allowed the approval of conservation areas on private lands easing the requirement of land titles, thousands of hectares could be saved not only for conservation purposes but also for sustainable use of forest since, in the case of the study area, the recognition of legal forestry production in private holdings has the same legal requirement i.e. the same problem as private reserves.

In the current land property revision process, indigenous, peasants and organisations of landless people are concerned about a possible unfair use of private reserves to accumulate land by large landowners, in particular considering the unequal concentration of land, also seen in the study zone. It must be recognised that as long as the unequal distribution of land is not solved, any measure will not be sustainable in the long term. Therefore, it is urgent that the process of land revision must be undertaken faster than before and looking for active social participation of all stakeholders (communities, private landowners, loggers, municipalities, etc.).

Nevertheless, while property rights are checked, areas with priority for conservation such as the three key bridge-areas that ensure the connectivity in the study zone (see 5.1.5) should receive special treatment by the governmental institutions.

\subsubsection{Adjustments within the land management norms}

\section{Interdisciplinary and detailed evaluation of land use in areas of high conservation importance}

In general terms, the Bolivian norms of land use plans for private properties are not complex; they were designed in this form in order to have a simple and cheap form for planning, which encourages landowners to carry out land planning. The principle of "Prima Visu" (SIF 1997) ("at first sight") is used for classification of soils, trusting in the experience of the technicians (mainly agricultural engineers) who are in charge of undertaking the plans. In addition, a unique guide for planning is used for every ecoregion.

However, this "simplification" contrasts with the necessity of carrying out detailed studies in areas that are important for the conservation of biodiversity or environmental services. Additionally, the complexity of the geo-eco-diversity of Bolivia (Gerold 2004), does not 
justify the existence of overall norms, which simplify the ecosystems and, in fact, have lead to a wrong evaluation of the biodiversity.

For the previous reasons, technical specific norms of land-use are needed for each ecoregion, which specifically recognise the potential of use and biological value in every holding. Besides, land planning in areas with priority for conservation, like the study zone, should have special norms. Thus, it is highly recommended that the process prioritise interdisciplinary work (with biologists, agricultural and forest technicians) in order to have an integral perspective that guarantees the best balance between production and conservation.

\section{Surface increase of compulsory protection areas}

A good definition of a minimum surface of compulsory protection areas (ecological servitudes) could enhance conservation in private holdings, in particular, where landowners do not want to set aside areas for biodiversity.

In the case of the transitional Chiquitano-Amazon Region, compulsory protection areas like small temporal streams, riverbanks and small elevations, house important wildlife according to the rapid assessments and field observations. Therefore, the increase of these areas is justified for improving conservation, especially in areas identified having a high biological value.

The general results of land planning in the study zone showed that on average less than $10 \%$ of each holding were set aside for compulsory conservation; this fact is very critical taking into consideration the current threats for connectivity. Furthermore if the biological concepts of minimum area size for viable population are considered, then the protected surface would be larger than the current one. But private properties are basically productions units and if protection measures have to be implemented, then realistic and feasible proposals should be given.

Hence, only for the zone of study, a proposal of more favourable distances are presented in table 45 , in order to promote the future discussion about compulsory ways to protect wildlife on private land. The proposed areas are based on empirical observations, but obviously, they must be checked and tested.

Probably the most important endangered species in the region (for instance tigers and wild mammals) will not benefit from these compulsory areas due to small size, but they will contribute to the development of other species as well as to the protection of the production 
basis (water and soils), aspects that could lower the pressure for natural places. Nowadays important production areas like the "area integrada de Santa Cruz" are threatened by land degradation in part due to the lack of compulsory area enforcement.

Regulatory government organisations are in charge of technical dispositions for compulsory areas. They can change these norms through administrative technical dispositions, which represent the easiest way to make changes and progress in the short time considering the long periods needed for structural changes. Thus, one of the most important challenges for institutions, promoting private land conservation is to induce a solid institutional cooperation with these organisations.

Table 45: Proposed distances for compulsory protection areas in the zone of study

\begin{tabular}{|c|c|c|c|}
\hline \multicolumn{2}{|c|}{ Protection unit } & Current disposition (m) & Proposed Distances \\
\hline \multicolumn{2}{|c|}{ Windbreak trees } & $\begin{array}{l}\text { Minimum width } 10 \mathrm{~m} \text {. } \\
\text { Distance between windbreak } \\
\text { lines equal } 10 \text { times the } \\
\text { height of the dominant trees }\end{array}$ & $\begin{array}{l}\text { Width of curtains } 50 \\
\text { meters }\end{array}$ \\
\hline \multirow{3}{*}{$\begin{array}{l}\text { Buffer of } \\
\text { temporal } \\
\text { streams }\end{array}$} & Flat non erodable land & 10 & 25 \\
\hline & Flat erodable land & 20 & 50 \\
\hline & Wavy land & 10 & 25 \\
\hline \multirow[t]{3}{*}{$\begin{array}{l}\text { Buffer of } \\
\text { rivers }\end{array}$} & $\begin{array}{l}\text { Not erodable potentially } \\
\text { flooded land }\end{array}$ & 50 & 100 \\
\hline & $\begin{array}{l}\text { Terrestrial erodable } \\
\text { potentially flooded land }\end{array}$ & 100 & 200 \\
\hline & Hilly land & 50 & 100 \\
\hline $\begin{array}{l}\text { Buffer of } \\
\text { Lagoons, } \\
\text { lakes }\end{array}$ & & 100 & 200 \\
\hline $\begin{array}{l}\text { Buffer of } \\
\text { Public roads }\end{array}$ & & 10 & 20 \\
\hline
\end{tabular}

\section{Use categories that consider the biodiversity conservation and environmental services}

The land planning normative establishes two basic groups of categories within private holdings: productive land and fragile land (compulsory protected areas). The categories of fragile land in private ownerships were designed from the point of view of soil conservancy (soil centrism). Although these may protect some biological values, they are not enough to 
preserve other areas which do not fulfil soil conservation criteria (that is, not fragile soils), for instance, headwaters in open areas and particular refugees for wild animals.

For the above-mentioned, the complementation of categories that protect biological biodiversity in a compulsory way may improve the possibilities of conservation in the region.

\subsubsection{Inclusion of private land conservation in municipal land planning}

Municipal development planning has recently increased its importance in Bolivia because of the Popular Participation law established in 1994. Nowadays, municipalities play a major role in the management of natural resources at a regional level. For this reason, these entities can greatly enhance private land conservation through municipal land policies.

Municipalities can undertake municipal land plans, which comprise categories of soil use according to environmental potential and socio-economic conditions; this level is intermediate between departmental land planning (like PLUS) and farm planning. In municipal planning, conservation necessities can be identified within municipal territories and local municipal governments can establish restrictions of use for areas needing protection (for example water reserves). Under these circumstances, positive synergies may be developed integrating conservation on private land within the options of municipal categories of land-use; in particular, considering that most of the land is in private hands, necessities of conservation in some municipalities cannot be carried out without the participation of private landowners.

Advantages of municipal intervention are the possibility of direct involvement of proprietors in the control of the enforcement of regulatory dispositions and of local organisations that could help the diffusion of conservation objectives. However, municipalities' capacities should be improved, as well as the co-ordination mechanism with other institutions.

\subsubsection{Strengthening of legal security of land property as main realistic incentive}

One of the most important conditions that allow private land conservation is the existence of a strong juridical system supporting the commitments assumed by landowners. If proprietors don't have legal guarantees, then they will hardly agree to set aside areas for biodiversity conservation.

A juridical insecure situation of land property occurs at the moment in Bolivia. During the carrying out of this study, as never before, private holdings, national protected areas, as well as forest reserves have faced invasion and occupation by colonists. Governmental institutions 
have partially controlled some cases, but, in general, this explosion of land demand needs for structural solutions (see next chapter).

In Bolivia during the past 10 years, a corrupt political system has benefited certain groups of power. In this way, the government (and its land policies) lost credibility. The general dissatisfaction has generated, in October 2003, social convulsion followed by the resignation of the in 2002 elected president.

In this context, with regard to the insecurity in land tenure, changes are required to stabilise the potential land conflicts. Some urgent measures would be the simplification of the bureaucratic procedures to determine land rights, the participation of all stakeholders and social control.

\subsubsection{Necessary structural changes}

\subsubsection{Necessary changes in the concept of a social and economic function of the land}

As was previously mentioned, the most important part of the Land Law of Bolivia is the recognition of land properties: the economic and social function of the land. This evaluation only focuses on the productive land use and the conservation of fragile soils. Biodiversity conservation and the protection of environmental services are only of secondary importance. Thus, there is an excessive tendency to concentrate land management in productive activities ignoring the existence of many areas with use restrictions.

In order to stress the ecological importance of land management, it is proposed that the evaluation of land use focuses on an economic-social-ecological function (FESE), which should be the basis or reference to increase the importance of biodiversity conservation as a part of the sustainable development.

\subsubsection{Necessity of national land-use law}

Until present, many efforts have been made to carry out land use and natural resource planning in Bolivia, but these processes have been undertaken in a partial way and, in many cases, in an isolated way resulting in a situation of dispersion of information, lack of monitoring and duplication of work. In addition, planning processes have been done without the coordination with local strategies and little direct participation of the people, which resulted in social actors' ignorance about recommendations and restrictions. 
The lack of a national land-use policy structurally affects the possibility to incorporate more actors of the civil society (as private proprietors, indigenous people and others) into sustainable management of landscapes and then in conservation of biodiversity. For this reason, it is necessary to elaborate a national land-use law that defines norms and regulations for the appropriate use of resources.

The regulation of land use according to social, economic and ecological characteristics would allow the identification of priority areas for conservation. So might, for instance, the creation of biological corridors among protected areas, in strict relationship with national land policies, solve some conflicts among the different stakeholders of rural areas of Bolivia.

Because of recent conflicts and social pressure, the constitution will be reviewed in the next years, in Bolivia. This could mark the historical moment to propose national norms. Appropriate and socially viable land use policies would lead the country towards a real sustainable development.

\subsubsection{Necessity of a specific legislation to promote the participation of the civil society in biodiversity conservation}

The conservation of biodiversity outside protected areas began with isolated initiatives without the support of the state. The approval of the environmental, forest and land laws in the middle of the 1990s has provided a legal framework to lead the administration of biodiversity, but up to now the topic of a direct participation of the civil society has not been treated adequately, even though its positive potential.

Furthermore, there are policy failures such as the current legislation on protected areas (regulation of protected areas) which should allow the establishment of private protected areas but has not yet been completed, thus preventing private land conservation regarding.

Recently, a proposal of a law for protected areas has been discussed in Bolivia. This new law has among its controversial points the creation of private protected areas. Indigenous groups and rural communities consider that conservation on private lands may create a way to legalise illegal land accumulation without economic or social use. In fact, this mentioned risk exists, but effective control processes, monitoring and social control could diminish the risk of an unfair use of this conservation option. Apart from this risk, the lack of clear legislation also harms the access of indigenous and peasants to a legal base that recognises their contribution to biodiversity conservation. 
Hence, specific legislation that allows a real participation of all social sectors is required. These legal rules should open equal opportunities to all proprietors, good control mechanisms, the security for land property. Disagreements should be solved through dialogues and feedback joining all stakeholders. New legal rules have neither to promote illegality, nor to stop the opportunity to make private conservation a contribution to sustainable development.

\subsection{Scenarios and perspectives for private land conservation}

\subsubsection{Scenarios for conservation on private lands}

In this chapter, an approach to describe the scenarios for development of conservation on private land is given. To this end, first of all, the observed trends in the development of private land conservation must be analysed in order to have a starting point for drawing the scenarios.

The establishment of the so-called "New Forestry Law" in 1997 gave the legal framework for the recent movement of private conservation in Bolivia (Choquehuanca 2004). However, only in the past four years a significant increase in the number of private reserves has been noticed (see figure 52). This increase is without doubt due to the proprietors' interest for showing legal land-use in the ongoing land tenure process carried out by the Bolivian governments. As mentioned in chapter 2.3.1., private reserves created until 2003 respond to dispersed independent initiatives, therefore, one may expect the same rate of growth in the creation of private reserves in the following years, but it will be limited to holdings with land titles, of which there are very few in the studied area.

In 2000, non-governmental organisations began explorative projects to systematically support private conservation looking at conservation criteria. These actors are playing and will play a decisive role for the future of private conservation removing the obstacles to this topic.

To draw scenarios, the main factors identified in this study should be considered. On the one hand, there are the following constraints: (a) the unsolved land property situation, (b) the lack of effective incentives, (c) the bureaucratic procedures, (d) weak enforcement of environmental laws and (d) land policies that indirectly push landowners towards the conversion of natural ecosystems; on the other hand, positive factors exist as well such as (a) 
the good conservation status, (b) the low population density of the zone and (c) the owners' necessity of land use options in a place with still few opportunities of development.

Figure 52: Chronological increase of Natural Heritage Private Reserves in Bolivia

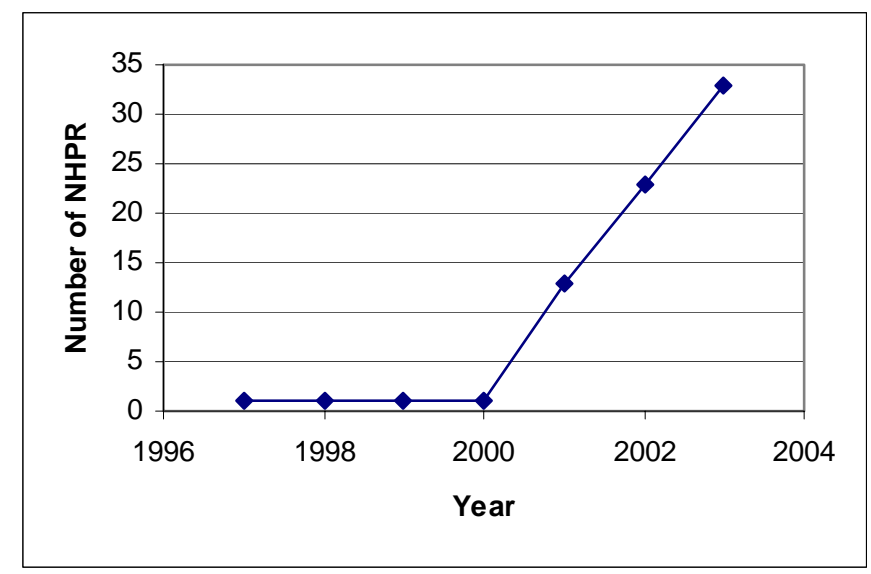

Source: Bolivian Forestry Superintendence. Annual reports 2000 - 2003

In the following paragraphs, the mentioned factors are weighed up in order to present the scenarios taking a short-term and long-term time horizon.

\subsubsection{Scenarios in the short time}

Among the constraints limiting the growth of private conservation, the land titling problem and the lack of effective incentives will hardly be solved in the short term, therefore positive and negative scenarios will be determined by the management of the other factors. Thus, a small increase in the number of private reserves and more conversion of forest is expected if the capacity of governmental institutions for enforcing the environmental laws is not supported and the non-governmental institutions stop their efforts (the worst case). The opposite of that will create a favourable scenario for conservation. This model underlines why coordinate actions between civil society and governments are important, since neither the unique actions of conservationists nor the governmental initiatives will be effective. 
Table 46: Scenarios of private land conservation in the short-term

\begin{tabular}{|c|c|c|c|}
\hline Scenarios & Positive conditions & Negative conditions & Trends \\
\hline $\begin{array}{l}\text { The worst } \\
\text { case }\end{array}$ & $\begin{array}{l}\text { Existence of forest regulations } \\
\text { Existence of land use regulations } \\
\text { Process of land tenure revision }\end{array}$ & $\begin{array}{l}\text { Land tenure conflicts } \\
\text { Lack of effective incentives } \\
\text { Bureaucratic procedures } \\
\text { Weak enforcement of laws } \\
\text { NGOs stop project of private } \\
\text { land conservation }\end{array}$ & $\begin{array}{l}\text { Little creation of private } \\
\text { reserves } \\
\text { Conversion of forest to } \\
\text { show legal use of land } \\
\text { Fragmentation of } \\
\text { Chiquitano forest }\end{array}$ \\
\hline $\begin{array}{l}\text { The best } \\
\text { case }\end{array}$ & $\begin{array}{l}\text { Existence of forest regulations } \\
\text { Existence of land use regulations } \\
\text { Ongoing process of land tenure } \\
\text { revision } \\
\text { Significant investment of NGOs in } \\
\text { private conservation } \\
\text { Integration of private conservation } \\
\text { in municipal planning }\end{array}$ & $\begin{array}{l}\text { Land tenure problems } \\
\text { Lack of effective incentives } \\
\text { Bureaucratic procedures } \\
\text { Weak enforcement of laws }\end{array}$ & $\begin{array}{l}\text { Establishing of a relative } \\
\text { number of private reserves } \\
\text { in order to preserve land } \\
\text { property rights }\end{array}$ \\
\hline
\end{tabular}

\subsubsection{Scenarios in the long term}

The creation of effective incentives, adjustment in land and environmental policies and the design of specific legislation as well as a long-term work of environmental NGOs will promote the inclusion of private conservation initiatives as a part of a successful strategy of conservation and so that the fragmentation of the Chiquitano Forest will be prevented. This favourable scenario would be sustainable only if the stakeholders in the region would allow a fear land distribution.

Table 47: Scenarios of private land conservation in the long-term

\begin{tabular}{|c|c|c|c|}
\hline Scenarios & \begin{tabular}{|c|} 
Positive conditions \\
\end{tabular} & $\begin{array}{l}\text { Negative conditions } \\
\end{array}$ & Trends \\
\hline $\begin{array}{l}\text { The worst } \\
\text { case }\end{array}$ & $\begin{array}{l}\text { Existence of forest regulations } \\
\text { Existence of land use regulations } \\
\text { Process of land tenure revision } \\
\text { concluded }\end{array}$ & $\begin{array}{l}\text { Land tenure conflicts } \\
\quad \text { Lack of effective incentives } \\
\text { Bureaucratic procedures } \\
\text { Weak enforcement of laws } \\
\text { NGOs do not support private } \\
\text { land conservation }\end{array}$ & $\begin{array}{l}\text { Little creation of private } \\
\text { reserves } \\
\text { Fragmentation of } \\
\text { Chiquitano Forest }\end{array}$ \\
\hline $\begin{array}{l}\text { The best } \\
\text { case }\end{array}$ & $\begin{array}{l}\text { Existence and effective } \\
\text { enforcement of } \\
\text { Forest regulations } \\
\text { Land use regulations } \\
\underline{\text { Specific legislation for private }} \\
\frac{\text { conservation }}{\text { Long-term NGOs' work in private }} \\
\frac{\text { conservation }}{\underline{\text { Creation of effective }}} \\
\frac{\text { incentives (e.g. Found for }}{\text { environmental services) }}\end{array}$ & $\begin{array}{l}\text { Land tenure problems } \\
\text { Lack of effective incentives } \\
\text { Bureaucratic procedures } \\
\text { Weak enforcement of laws }\end{array}$ & $\begin{array}{l}\text { Functional connectivity of } \\
\text { Chiquitano Forest is } \\
\text { ensured }\end{array}$ \\
\hline
\end{tabular}


Finally, it must be said that these scenarios are not absolute, because land-use and conservation is determined by diverse factors, thus the approach presented in this chapter can be discussed, critiqued and improved, but it is expected this approach leads to the best choice of the most urgent measures to promote private conservation.

\subsubsection{Private conservation opportunities among the social conflicts of Bolivia}

In 2003, the worst violent conflict in the democratic period of Bolivia has occurred due to discontent and demand of social justice (see box 2). Bolivia has been a democracy since 1982, but since then, inequalities of wealth have increased and there has been no reduction in poverty. The attempt to export gas to Mexico and the USA, without a process of consulting and information triggered the conflict mainly because the impoverished indigenous majority of the people of Bolivia felt that the trade and the economy are run for the benefit of a small wealthy elite.

These conflicts have marked a change in the traditional manner of political conduct. As a result, a revision of the structural basis of the country was begun and in addition, new ways to incorporate social participation were included in the legal rules of the state - these are the referendum and the constitutional assembly.

Insecurity in all activities has characterized the Bolivian situation after this conflict, but slowly the democratic institutions of Bolivia have regained control. In July 2004, a referendum established the majority decision in favour of the gas export and after that a preparatory process for the constitutional assembly was undertaken. This will change the Bolivian constitution towards an improvement of the living condition of the citizens.

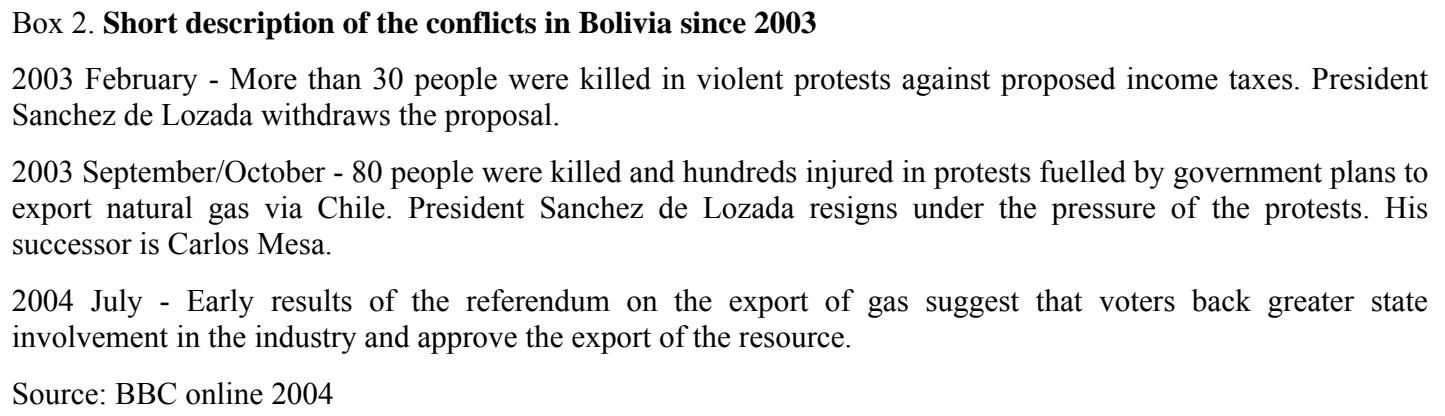


Under these circumstances, biodiversity conservation policies will likely be affected by these winds of change; in particular because of two social aspirations: fair land distributions and a strong tendency to political decentralisation.

A new and improved political system is expected after the change of the Bolivian constitution, especially because, for the first time in the history of Bolivia a priority is given to the democratic participation of indigenous people and citizens. This breaks the political monopoly of the political parties.

Whatever changes will be made in the environmental policies of Bolivia, it will be fundamental that the majority of the decision-makers have adequate information about the importance of conservation and the concept of priority areas. For this reason it is of utmost importance to open mechanisms of communication and information. Conservationists' institutions and researches must prepare solid arguments and new tools of negotiation to integrate conservation principles in the new policies with social responsibility.

The security of land property rights, the respect for conservation and incentives for the protection of wildlife are main principles to improve private land conservation, but they can be hard to achieve under such a high poverty rate as in Bolivia (68\%). Therefore, the expected changes in the political system may enhance the conditions for a direct participation of the people in conservation. 


\section{CONCLUSIONS AND RECOMMENDATIONS}

\subsection{Conclusions}

\section{Conservation status and priority areas in the study zone}

The results of the study confirm that the "Transitional Region Chiquitano-Amazon" has a major importance for the maintenance of biological connectivity because of the strategic location between the ecoregions of the Chiquitano Forest (semi-arid) and the Amazon Forest (humid). The whole region houses a relatively high biodiversity, the outskirts of Manomo Hill being the place with the highest diversity.

Most of this zone has a good conservation status ( $86 \%$ of total area). This characteristic is mainly explained by the low development of road infrastructure and the distant location of this region in relation to the main population centres in the country. From an ecologist perspective these features are great advantages for conservation planning. However, there are tendencies of change as a result of an increasing interest in economic integration of the neighbour country Brazil. Thus, deforestation processes have started near the main road and they are the main threat for biodiversity and connectivity, but there are still opportunities to conduct these changes in a way that do not harm severely the biological values.

The land tenure analysis shows a disproportional land distribution. While large private landowners occupy circa $60 \%$ of the study zone, only about $10 \%$ is in the hands of indigenous communities, although they represent the majority of the population. Proved fiscal land comprises around $28 \%$ of land, of which $25 \%$ is in hand of local logging organizations and two per cent is a protected municipal area. However, this land distribution is not yet fixed because the revision of property rights is currently in progress. According to the legal restrictions of land-use, in around $56 \%$ of the study area deforestation and land conversion are forbidden.

To achieve the conservation of wildlife and the maintenance of connectivity in the study zone, the main strategy is to preserve the connection between the forested areas and the protected municipal area. This aim could be achieved by promoting conservation activities in those $20 \%$ of the whole territory that are in the hands of large-scale private landowners. Considering 
these $20 \%$ of the area, the most critical part is located near the international road San Ignacio - San Matias in which urgent measures against deforestation must be undertaken.

\section{Landowners' predisposition for conservation}

The results of the land use planning of the holdings carried out with a conservation perspective, which were conducted in the areas with conservation priority, indicate three types of landowners with particular behaviour when it was proposed to them to set aside areas for biodiversity conservation.

The first group consists of proprietors that feel affection for the natural values of their holdings. These landowners accept easily to take part in conservation activities, that is the establishment of voluntary protected areas. This type is the most important group to encourage private land conservation, nevertheless they represent a very small number of proprietors.

A second group of owners are mainly characterized by the possession of large natural areas without intervention, the lack of economic resources (capital) and a high interest to ensure the land property rights. These landowners were initially interested in establishing private protected areas, but they were discouraged by legal requirements, bureaucratic procedures and costs of future maintenance of conservation activities. This suggests that they are looking for viable land-use options to avoid land reversion rather than being interested in the protection of wildlife.

The third group is comprised of landowners with better economic resources to carry out aggressive agricultural activities and land conversion (deforestation). They probably own the largest area in the study zone and they have manifested a low interest in biodiversity conservation without economic compensations. The enforcement of compulsory protection of land seems to be the best way to promote conservation in those holdings.

On the whole, the number of proprietors who accepted voluntarily to establish private reserves in their holdings and who are able to carry out and finish the process of governmental recognitions of private reserves is very small. However most of landowners have shown a special interest in land-use planning, thus the development of projects that promote ecologically-based land arrangements could enhance conservation measures on private land. 


\section{Potential of biodiversity conservation on private land}

In general, the results of this study suggest very good opportunities to promote conservation in the region, in particular due to the large area with a good status of conservation and the predisposition of the landowners for land planning. Nevertheless, the insecurity of land property, the lack of effective incentives, very complicated legal procedures and failed policies have stopped the establishment of conservation areas on private lands.

It must be underlined that even if the situation of land tenure may be solved, the absence of economical revenues for conservation (incentives) still represents the major constraint against long-term processes of conservation in private holdings. In this way a utopian concept of private conservation, which attempts to set aside all holdings' surfaces for conservation, cannot lead to successful results.

However, private conservation has a high potential to contribute to biodiversity protection in this region if it is integrated in the production system through interdisciplinary land planning. In addition, practices of sustainable management as controlled logging, organic cattle production and agroforestry systems should be considered as mechanisms of realistic private land conservation.

\subsection{Recommendations}

\section{Incentives and strategies}

Private conservation will be possible only if it is encouraged by effective incentives; the current advantages given by the current norms (Forestry Law) are in fact not attractive for landowners. It has been shown that technical (land planning) and legal support, as well as the recognition of the owner's conservation efforts are currently effective and viable incentives that institutions can easily provide and develop. These could be the starting point for a development of other incentives.

Furthermore, environmental conditions and land-use potentials suggest to develop incentives for forest production, in particular practices that enhance natural regeneration of commercial species during the periods of conservation. The support of eco-tourism could promote the establishment of private reserves, but analysis of economic viability must be executed beforehand in order to avoid excessive expectations and discouragement. 
Payments for environmental services or economic compensations for conservation are still far from being implemented; it seems that more studies and political lobbying are needed to create the social and economic conditions that allow these incentives.

Institutional strategies should be enforced to involve the civil society in private conservation and to achieve the social recognition of conservation on private holdings. The outcomes of the study suggest the following measures: joint work between the private sector and the government, fortification of key governmental institutions, proactive monitoring of the process of land tenure revision as well as the diffusion of information and education about private conservation.

\section{Policy changes}

This study identified contradictory policies about land management and the protection of biodiversity on private land that lead to an increasing destruction of natural values. Therefore, changes in policies should be recommended in order to ease a realistic and direct participation of landowners in biodiversity conservation.

In the short term, policy changes as adjustments of different regulations of conservation and forest use, adjustments of land management norms, inclusion of private land conservation in municipal land planning and strengthening of legal security of land property should be taken into consideration by policy decision-makers.

In addition, structural changes are needed. Thus, it is highly recommended that social institutions and researchers promote the inclusion of a strong ecological view in the conception of the social economic function of land. The necessity of a national land-use law that leads the sustainable development is a further necessary change, besides the revision and complementation of specific legislations to promote private participation in biodiversity conservation. 


\section{REFERENCES}

Araujo, N. \& P.L. Ibisch (eds.) (2000): Hacia un Plan de Conservación para el Bio-Corredor Amboró - Madidi, Bolivia. Editorial FAN, Santa Cruz de la Sierra - Bolivia (CD-ROM; ISBN 99905-801-7-0).

Armijo, E. \& J. C. Chivé (2002): Sistema de información geográfica. En: Ibisch, P. L., K. Columba \& S. Reichle (eds.) (2002): Plan de Conservación y Desarrollo Sostenible para el Bosque Seco Chiquitano, Cerrado y Pantanal Boliviano. Editorial FAN, Santa Cruz de la Sierra - Bolivia. I.17 - I.19.

Bates, J. M., D. F. Stotz, \& T. S. Schulenberg (1998): Avifauna of Parque Nacional Noel Kempff Mercado. In: T. J. Killeen, \& T. S. Schulenberg (eds.) (1998): A biological assessment of Parque Nacional Noel Kempff Mercado and adjacent areas, Santa Cruz, Bolivia. Conservation International, Washington D.C.

Black, T. R. (1999): Doing quantitative research in the social sciences. An integrated approach to research design, measurement and statistics. Sage Publications. London.

Bernard, R. H. (2000): Social research methods. Qualitative and quantitative approaches. Sage Publications. London.

Bounoua, L., R. S. DeFries, M. L. Imhoff \& M. K. Steininger (2003): Land use and local climate: A case study near Santa Cruz, Bolivia. Meteorology and Atmospheric Physics. Springer - Verlag. Austria. 86:73 - 85.

Bradshaw, M. \& R. Weaver (1993): Physical geography: An introduction to earth environments. Mosby - Year book, Inc. St. Louis.

Burrough, P. A. \& R. A. McDonnell (1998): Principles of geographical information systems. Oxford University Press. New York.

Calvo, L.M. (2004): Problems and threats for the indigenous and native groups and the local communities with regards to the conservation and sustainable use of biodiversity. In: Ibisch, P. L. \& G. Mérida (eds.) (2004):Biodiversity: The richness of Bolivia. State of knowledge and conservation. Ministry of Sustainable Development. Editorial FAN, Santa Cruz de la Sierra - Bolivia. 184 - 197.

Camacho, M. A. \& V. Reyes (2002): Pago por servicios ambientales. Octavo informe sobre el estado de la nación en desarrollo humano sostenible. Consejo Nacional de Sectores. La Defensoría de los Habitantes. United Nations Development Programme. San José Costa Rica.

Castelli, L. (2001): Conservación de la naturaleza en tierras de propiedad privada. Fundación Ambiente y Recursos Naturales (FARN) - Fundación Turner. Buenos Aires - Argentina (http://www.farn.org.ar).

CEDA (Centro Ecuatoriano de Derecho Ambiental) (2003): Ecuador, Country Partner. Country report of private land conservation. In: ELI et. al. (2003): Legal tools and 
incentives for private lands conservation in Latin America: Building models for success. Washington D. C. $121-135$.

CEDARENA (Centro de Derecho Ambiental y de los Recursos Naturales) (2000): Definiendo herramientas para la influencia política orientadas al desarrollo sostenible. ARCA. San Jose -Costa Rica.

CEDARENA (Centro de Derecho Ambiental y de los Recursos Naturales) (2003): Costa Rica, country partner. Country report of private land conservation. In: ELI et al. (2003): Legal tools and incentives for private lands conservation in Latin America: Building models for success. Washington D. C. $103-119$.

Chacón, C. \& R. Castro (eds.) (1998): Conservación de tierras privadas en América Central. Utilizando herramientas legales voluntarias. Iniciativa Centroamericana de Conservación Privada - Centro de Derecho Ambiental y de los Recursos Naturales (CEDARENA). San José - Costa Rica.

Chape, S., S. Blyth, L. Fish, P. Fox \& M. Spalding (compilers) (2003): United Nations List of Protected Areas. IUCN. Gland, Switzerland and Cambridge. UK and UNEP-WCMC. Cambridge, UK.

Choquehuanca, J. (2001): Analysis of the establishment of private natural reserves in the buffer-zone of Amboro National Park - Bolivia. Georg-August University. Department of Landscape ecology. Göttingen - Germany.

Choquehuanca, J. (2003): Challenges of the Implementation of Private Reserves (RPPN). II National Meeting of Forest Investigation. Towards Sustainable Forest Management: Profits and Strategies for the Forest Investigation in Bolivia. Abstracts. Cochabamba, Bolivia.

Choquehuanca, J. (2004): Private Conservation in Bolivia. In: Ibisch, P. L. \& G. Mérida (eds.) (2004): Biodiversity: the richness of Bolivia. State of knowledge and conservation. Ministry of Sustainable Development. Editorial FAN, Santa Cruz de la Sierra - Bolivia. $370-376$

Choquehuanca, J. \& S. Eguino (2003): Final report of the project "Private Conservation in the Corridor of Americas". Fundación Amigos de la naturaleza (FAN - Bolivia). Unpublished document. Santa Cruz - Bolivia.

CODEFF (Comité Nacional Pro Defenza de la Flora y de la Fauna) (2003): Chile, country partner. Country report of private land conservation. In: ELI et. al. (2003): Legal tools and incentives for private lands conservation in Latin America: Building models for success. Washington D. C. $83-102$.

Columba, K. (2002): Sistema económico. Derechos sobre la tierra y los recursos naturales. En: Ibisch, P.L., K. Columba \& S. Reichle (eds.) (2002): Plan de Conservación y Desarrollo Sostenible para el Bosque Seco Chiquitano, Cerrado y Pantanal Boliviano. Editorial FAN, Santa Cruz de la Sierra - Bolivia. II.143 - II.159.

Cordona, C. (2003): Roadside Measurement of Deforestation in the Amazon Area of Bolivia. Environmental management 31(6): 774-783. Springer-Verlag. New York. 
Czech, B. (2002): A transdisciplinary aproach to conservation land acquisition. Conservation Biology. Vol. 6, No. 6. Dezember 2002.

ELI (Environmental Law Institute), CEDARENA (Centro de Derecho Ambiental y de los Recursos Naturales), CEDA (Centro Ecuatoriano de Derecho Ambiental), CODEFF (Comité Nacional pro Defensa de la Flora y de la Fauna), Fundação O Boticário de Proteção a Natureza, Pronatura, A.C., PROMETA (Protección del Medio Ambiente Tarija), SPDA (Sociedad Paruana de Derecho Ambiental). (2003): Legal tools and incentives for private lands conservation in Latin America: Building models for success. Washington DC.

Emmons, L. H. (1998): Mammal fauna of Parque Nacional Noel Kempff Mercado. In: T. J. Killeen \& T. S. Schulenberg (eds.) (1998): A biological assessment of Parque Nacional Noel Kempff Mercado and adjacent areas, Santa Cruz - Bolivia. Conservation International, Washington D. C. $129-135$.

Fahsen, F. \& X. Macorra (2003): Guatemala, country summary. Country report of private land conservation. In: ELI et. al. (2003): Legal tools and incentives for private lands conservation in Latin America: Building models for success. Washington DC. 137 142.

FAN \& TNC (1996): Plan de Manejo del Parque Nacional Noel Kempff. No publicado. Fundacion Amigos de la naturaleza. The Nature Concervancy.

Flores, B., D. I. Rumiz, T. Fredericksen \& N. Fredericksen (2001): Uso de claros de aprovechamiento, por las aves de un bosque húmedo tropical boliviano. Documento Técnico 100/2001. Proyecto BOLFOR - USAID. Santa Cruz - Bolivia.

Flores, B., D. I. Rumiz \& G. Cox (2001a): Avifauna del bosque semideciduo Chiquitano (Santa Cruz - Bolivia) antes y despues de aprovechamiento forestal selectivo. Revista brasileira de ornitología - Ararajuba. 9 (1). Junio.

Fredericksen, T. (2004): Degradation and loss of biodiversity due to the use of forest resources. In: Ibisch, P. L. \& G. Mérida (eds.) (2004): Biodiversity: The richness of Bolivia. State of knowledge and conservation. Ministry of Sustainable Development. Editorial FAN, Santa Cruz de la Sierra - Bolivia. 239 - 242.

Fundación Bertoni (2000): Las iniciativas de conservación privada en el Paraguay. Una Revisión de 10 años de Experiencias.

Fundação O Boticario de Proteção ã Natureza (2003): Brazil, country partner. Country report of private land conservation. In: ELI et. al. (2003): Legal tools and incentives for private lands conservation in Latin America: Building models for success. Washington D. C. $61-77$.

Gerold, G. (1983): Vegetationdegradation und fluviatile Bodenerosion in Südbolivien. Z. geomorph N. F.,Suppl. Bd. 48: 1-16.

Gerold, G. (2004): Soils: The foundation of biodiversity. In: Ibisch, P. L. \& G. Mérida (eds.) (2004): Biodiversity: The richness of Bolivia. State of knowledge and conservation. Ministry of Sustainable Development. Editorial FAN, Santa Cruz de la Sierra - Bolivia. $17-31$. 
Gerold, G., M. Fremerey \& E. Guhardja (eds.) (2004): Land use, nature conservation and the stability of rainforest margins in Southeast Asia. Springer-Verlag Berlin Heidelberg New York.

Guillén, R., P. L. Ibisch \& S. Reichle (2002): Formaciones y comunidades de vegetación. En: Ibisch, P. L., K. Columba \& S. Reichle (eds.) (2002): Plan de Conservación y Desarrollo Sostenible para el Bosque Seco Chiquitano, Cerrado y Pantanal Boliviano. Editorial FAN, Santa Cruz de la Sierra - Bolivia. II.32 - II.48.

Ibisch, P. L. (2004): Actors that impact biodiversity without making use of it. In: Ibisch, P. L. \& G. Mérida (eds.) (2004): Biodiversity: The richness of Bolivia. State of knowledge and conservation. Ministry of Sustainable Development. Editorial FAN, Santa Cruz de la Sierra - Bolivia. 198 - 203.

Ibisch, P. L. (2004a): Degradation and lost of biodiversity. In: Ibisch, P. L. \& G. Mérida (eds.) (2004): Biodiversity: The richness of Bolivia. State of knowledge and conservation. Ministry of Sustainable Development. Editorial FAN, Santa Cruz de la Sierra - Bolivia. $204-207$.

Ibisch, P. L. (2004b): Notes concerning gaps in protection in Bolivia. In: Ibisch, P. L. \& G. Mérida (eds.) (2004): Biodiversity: The richness of Bolivia. State of knowledge and conservation. Ministry of Sustainable Development. Editorial FAN, Santa Cruz de la Sierra - Bolivia. $382-406$.

Ibisch, P. L. (2004c): History of biodiversity conservation in Bolivia. In: Ibisch, P. L. \& G. Mérida (eds.) (2004): Biodiversity: The richness of Bolivia. State of knowledge and onservation. Ministry of Sustainable Development. Editorial FAN, Santa Cruz de la Sierra - Bolivia. $338-347$.

Ibisch, P. L., C. Nowicki, R. Gonzáles, T. Oberfrank, C. Specht, N. Araujo \& K. Minkowski (2000): Identification of conservation priorities in the Bolivian Amazon - A new biological-socio-economic methodology using GIS. Proceedings "Deutscher Tropentag 1999”. Knowledge partnership. Humboldt-University \& ATSAF, Berlin (CD-ROM)

Ibisch, P. L., K. Columba \& S. Reichle (eds.) (2002): Plan de Conservación y Desarrollo Sostenible para el Bosque Seco Chiquitano, Cerrado y Pantanal Boliviano. Editorial FAN, Santa Cruz de la Sierra - Bolivia.

Ibisch, P. L., C. Nowicki, R. Müller \& N. Araujo (2002a): Methods for the assessment of habitat and species conservation status in data-poor countries - case study of the Pleurothallidinae (Orchidaceae) of the Andean rain forests of Bolivia. In: Bussmann, R. W. \& S. Lange (eds.): Proceedings of the first international congress "Conservation of Biodiversity in the Andes and the Amazon Basin", September -2001, Cusco, Peru. 225 246.

Ibisch, P. L., J. C. Chive, S. Espinoza \& N. V. Araujo (2004): Towards a map of the conservation status of the ecosystems in Bolivia. In: Ibisch, P. L. \& G. Mérida (eds.) (2004): Biodiversity: The richness of Bolivia. State of knowledge and conservation. Ministry of Sustainable Development. Editorial FAN, Santa Cruz de la Sierra - Bolivia. $255-263$. 
Ibisch, P. L., S. G. Beck, B. Gerkman \& A. Carretero (2004a): Ecoregions and ecosystems. In: Ibisch, P. L. \& G. Mérida (eds.) (2004): Biodiversity: The richness of Bolivia. State of knowledge and conservation. Ministry of Sustainable Development. Editorial FAN, Santa Cruz de la Sierra - Bolivia. $47-86$.

Ibisch, P. L. \& J. Choquehuanca (2004): Use of Biodiversity within the context of environmental services. In: Ibisch, P. L. \& G. Mérida (eds.) (2004): Biodiversity: The richness of Bolivia. State of knowledge and conservation. Ministry of Sustainable Development. Editorial FAN, Santa Cruz de la Sierra - Bolivia. 314 - 321.

Ibisch, P. L. \& N. Araujo (2004): Regional conservation and biological corridors. In: Ibisch, P. L. \& G. Mérida (eds.) (2004): Biodiversity: The richness of Bolivia. State of knowledge and conservation. Ministry of Sustainable Development. Editorial FAN, Santa Cruz de la Sierra - Bolivia. 407 - 417.

Ibisch, P. L. \& G. Mérida (eds.) (2004): Biodiversity: The richness of Bolivia. State of knowledge and conservation. Ministry of Sustainable Development. Editorial FAN, Santa Cruz de la Sierra - Bolivia.

INE (Instituto Nacional de Estadística) (2002): Censo de población y vivienda 2001. La Paz Bolivia.

Hilty, J. \& A. M. Merenlender (2003): Studying Biodiversity on Private Lands. Conservation Biology. 17(1): 132-137.

Killen, T. J. \& T. S. Schulenberg (eds.) (1998): A biological assessment of Parque Nacional Noel Kempff Mercado, Bolivia. RAP Working Papers 10. Conservation International, Washington D. C.

Krüger, J. P. \& G. Gerhard (2003) Estimation of a potential landscape development regarding factors of forest conversion and soil degradation in eastern Bolivia. Conference on International Agricultural Research for Development. Deutscher Tropentag October, 2003. Göttingen.

Langholz, J., J. Lassoie \& J. Schelhas (2000): Incentives for Biological Conservation: Costa Rica's Private Wildlife Refuge Program. Conservation Biology 14 (6): 1735 - 1743.

Latrina, L., J. L. Cartes, A. va Humbeeck \& A. M. Macedo (2000): Programa de Apoyo a Iniciativas Privadas de Conservación: Una Revisión de 10 años de experiencias en Conservación Privada en Paraguay. Fundación Moises Bertoni. Asunción - Paraguay.

Levitt, J. (2001): Innovating on the Land: Conservation on the Working Landscape in American History. Background paper prepared for: Private Lands, Public Benefits: A Policy Summit on Working Lands Conservation National Governors' Association. Washington D.C.

Loening, L. J. \& M. Markussen (2003): Pobreza, deforestación y pérdida de la biodiversidad en Guatemala. Instituto Ibero-Americano de Investigaciones Económicas. Documentos de trabajo No 91. Georg-August-Universität Göttingen. Göttingen - Germany.

Lunney, D., A. Matthews, C. Moon, \& S. Ferrier (2000): Incorporating Habitat Mapping into Practical Koala Conservation on Private Lands. Conservation Biology. 14(3): 669-680. 
MDSP (Ministerio de Desarrollo Sostenible y Planificación) (2003): (Editores: G. Merida.,M.Olivera \& P.L. Ibisch) Estrategia Nacional de Conservación y Uso sostenible de la biodiversidad de Bolivia. Editorial FAN, Santa Cruz.

Mejias, R., J. Echeverría \& R. Solórzano (2000): Incentivos para la conservación de tierras privadas en América Central. CEDARENA, Centro Científico Tropical. San Jose Costa Rica.

Merenlender, A. M., L. Huntsinger, G. Guthey, \& S. F. Fairfax (2004): Land Trusts and Conservation Easements: Who Is Conserving What for Whom?. Conservation Biology 18 (1): 65-76.

MHNNKM (Museo de Historia Natural Noel Kempff Mercado) (2002): Criterios establecidos para planes de manejo de RPPN. Project: "POP and RPPN implementation in cattle ranches of Chiquitania region". (unpublished document).

Millington, A. C, X. M. Velez-Liendo, A. V. Bradley (2002): Scale dependence in multitemporal mapping of forest fragmentation in Bolivia: implications for explaining temporal trends in landscape ecology and applications to biodiversity conservation. ISPRS Journal of Photogrammetry \& Remote Sensing 57 (2003): 289-299.

Norton, D. A. \& C. J. Miller (2000): Some issues and options for conservation of native biodiversity in rural New Zealand. Ecological Management \& Restoration. Vol 1. No. 1. April 2000.

Nowicki, C. (2004): Naturschutzgebiete in Raum und Zeit. Biodiversitätsextrapolationen Klimaszenarien und soziodemographische Analysen als Instrumente der Naturschutzplanung am Beispiel Boliviens. Tropenökologisches Begleitprogramm (TÖB). Deutsche Gesellschaft für Technische Zusammenarbeit (GTZ). Eschborn, Deutschland.

Oporto, H. (2003): ¿De la reforma agraria a la guerra por la tierra?. En: Opiniones y Análisis. FUNDEMOS. La Paz - Bolivia.

Ortiz, E., L. Sage \& C. Borge (2003): Impacto del Programa de Pago de Servicios Ambientales en Costa Rica como medio de reducción de la pobreza en los medios rurales. Unidad Regional de Asistencia Técnica (RUTA), San José.

Pacheco, P. (2001): Deforestation and forest degradation in lowland Bolivia. In: Wood \& Porro (eds.) (2001): Land use and deforestation in the amazon. Gainesville. University Press of Florida Press.

Pacheco, P. (2001a): Bolivia. Country profile for the forum on "The role of forestry in poverty alleviation". Facilitated by the Forestry Department - FAO.

Pacheco, P. \& B. Mertens (2004): Land use change and agriculture development in Santa Cruz - Bolivia. Bois et Forêt des Tropiques 280(2):29-40.

Pattie, P. \& F. Merry (1999): Bosques vs. ganado: una evaluación económica de las alternativas para los propietarios de tierras en los llanos bolivianos. Documento técnico 74/1999. Proyecto BOLFOR USAID. Bolivia. 
Piskulich, Z. (2000): Incentivos para la Conservación de Tierras Privadas en América Latina. Iniciativa para la Conservación de Tierras Privadas en América Latina y El Caribe. The Nature Conservancy.

Powers, W. D. (2004): Bolivia successfully innovates in carbon sequestration. In: Ibisch, P. L. \& G. Mérida (eds.) (2004): Biodiversity: The richness of Bolivia. State of knowledge and conservation. Ministry of Sustainable Development. Editorial FAN, Santa Cruz de la Sierra - Bolivia. $317-319$.

Prefectura del Departamento de Santa Cruz (1996): Memoria del PLUS. Plan de uso de suelo del departamento de Santa Cruz, Bolivia. Secretaria Dptal. de Desarrollo Sostenible y medio Ambiente. Dirección Dptal. Recursos Naturales. CORDECRUZ/ GPP-KfWCONSORCIO IP/CES/KWC. Santa Cruz.

PROMETA (Protección del medio ambiente - Tarija) (2001): Áreas protegidas departamentales, municipales y privadas en Bolivia. Formulación de políticas para su creación y gestión. La Paz - Bolivia.

PROMETA (Protección del medio ambiente - Tarija) (2002): Instrumentos de conservacion privada en Bolivia. Formulación de políticas para su creación y gestión. La Paz Bolivia.

PROMETA (Protección del medio ambiente - Tarija) (2003): Bolivia, country partner. Country report of private land conservation. In: ELI et. al. (2003): Legal tools and incentives for private lands conservation in Latin America: Building models for success. Washington D. C. $49-59$.

PRONATURA, A.C. (2003): Mexico, country partner. Country report of private land conservation. In: ELI et. al. (2003): Legal tools and incentives for private lands conservation in Latin America: Building models for success. Washington D. C. 143 160.

Rafiqpoor, D. \& P. L. Ibisch (2004): The physical environment. In: Ibisch, P. L. \& G. Mérida (eds.) (2004): Biodiversity: The richness of Bolivia. State of knowledge and conservation. Ministry of Sustainable Development. Editorial FAN, Santa Cruz de la Sierra - Bolivia. $4-16$.

Reichle, S., C. Eulert, N. Acheson, D. Rumiz, L. Gonzales, V. Fuentes, J. Sarmiento, T. Gutierrez \& P. L. Ibisch (2002): Fauna. Estado de conocimiento. In: Ibisch, P. L., K. Columba \& S. Reichle (eds.) (2002): Plan de Conservación y Desarrollo Sostenible para el Bosque Seco Chiquitano, Cerrado y Pantanal Boliviano. Editorial FAN, Santa Cruz de la Sierra - Bolivia. II.60 - II.71.

Reichle, S., K. Columba, N. Araujo, E. Armijo, S. Cuéllar, R. Vides \& P. L. Ibisch (2002a): Metodología del proceso de evaluación integral. En: Ibisch, P. L., K. Columba \& S. Reichle (eds.) (2002): Plan de Conservación y Desarrollo Sostenible para el Bosque Seco Chiquitano, Cerrado y Pantanal Boliviano. Editorial FAN, Santa Cruz de la Sierra - Bolivia. I.19 - I.43.

Ribera, M. O. (2004): The National System of Protected Areas "Sistema Nacional de Áreas Protegidas (SNAP)". In: Ibisch P.L. \& G. Mérida (eds.) (2004): Biodiversity: The 
richness of Bolivia. State of knowledge and conservation. Ministry of Sustainable Development. Editorial FAN, Santa Cruz de la Sierra - Bolivia.

Rice, R. E., R. E. Gullison \& J. W. Reid (1997): Can sustainable management save tropical forest? Scientific American 276: 44-49.

Rice, R. E., C. A. Sugal, S. M. Ratay \& G. A. B. da Fonseca (2001): Sustainable forest management: a review of conventional wisdom. Center for Applied Biodiversity Science 3, Conservation International, Washington D. C.

Rice, R. E. (2003): Conservation Concessions - Concept Description. V World Parks Congress: Sustainable Finance Stream. September 2003, Durban, South Africa

Rosa, H., S. Kandel \& L. Dimas (2003): Compensation for environmental services and rural communities. Lessons from the Americas and Key Issues for Strengthening Community Strategies. Programa Salvadoreño de Investigación sobre Desarrollo y Medio Ambiente (PRISMA). San Salvador - El Salvador.

Saucedo, R. (1999): La Ingeniería Jurídica aplicada a los recursos naturales. En: Sociedad Boliviana de Derecho Ambiental (SBDA) (1999): Manus-Crito. Boletín Trimestral. Edición No 4 marzo - 1999. Santa Cruz - Bolivia.

SIF (SUPERINTENDENCIA FORESTAL DE BOLIVIA) (1997): Normas técnicas sobre planes de ordenamiento predial. Resolución Ministerial No 130/97. Ministerio de Desarrollo Sostenible y Medio Ambiente. Santa Cruz - Bolivia.

SIF (SUPERINTENDENCIA FORESTAL DE BOLIVIA) (2002): Reservas Privadas del Patrimonio Natural Directriz Técnica ITE 08/28/2002. Santa Cruz - Bolivia.

SIF (SUPERINTENDENCIA FORESTAL DE BOLIVIA) (2003): Informe anual 2002. Santa Cruz - Bolivia.

Sommer, J. H., C. Nowicki, L. Rios, W. Barthlott \& P. L. Ibisch (2003): Extrapolating species ranges and biodiversity in data-poor countries: The computerized model BIOM. Revista de la Sociedad Boliviana de Botánica. 4(1): 171-190. Santa Cruz - Bolivia.

Spector, S. (2002): Biogeographic Crossroads as Priority Areas for Biodiversity Conservation. Conservation Biology. 16(6):1480 - 1487.

Sociedad Boliviana de Derecho Ambiental (SBDA) (1999): Manus-Crito. Boletín Trimestral. Edición No 4 marzo - 1999. Santa Cruz - Bolivia.

SPDA (Sociedad Peruana de Derecho Ambiental) (2003): Peru, country partner. Country report of private land conservation. In: ELI et. al. (2003): Legal tools and incentives for private lands conservation in Latin America: Building models for success. Washington D. C. $167-170$.

Steininger, M. K., C. J. Tucker, P. Ersts, T. J. Killeen, Z. Villegas \& S. B. Hecht (2001): Clearance and Fragmentation of Tropical Deciduous Forest in the Tierras Bajas, Santa Cruz, Bolivia. Conservation Biology 15(4):856-866. 
Sundari, A., B. Cannon \& H. Orlando (2002): Enforcement Economics and the fight Against Forest crime; lessons learned from the Atlantic Forest of Brazil. Conservation International. Center for conservation and governement and Instituto de Estudios SocioAmbientais do sul da Bahia (draft, Washington D.C.).

Thomas, C. D., A. Cameron, R. E. Green, M. Bakkenes, L. J. Beaumont, Y. C. Collinham, B. F. N. Erasmus, M. Ferreira de Siqueira, A. Grainger, L. Hannah, L. Hughes, B. Huntley, A. S. van Jaarsveld, G. F. Midgley, L. Miles, M.A. Ortega-Huerta, A. Townsend Peterson, O. L. Phillips \& S. E. Williams (2004): Extinction risk from climate change. Nature. Nature Publishing Group. 427(8): 145 - 148.

UN (United Nations) (2002): Declaration of Johannesburg. World Summit on Sustainable Development. Johannesburg, South Africa.

UN (United Nations) (2002a): Plan of implementation of World Summit on Sustainable Development. Annex A. Johannesburg, South Africa.

Wachholtz, R. (2002): Geología, geomorfología, fisiografía y suelo. En: Ibisch, P. L., K. Columba \& S. Reichle (eds.) (2002): Plan de Conservación y Desarrollo Sostenible para el Bosque Seco Chiquitano, Cerrado y Pantanal Boliviano. Editorial FAN, Santa Cruz de la Sierra- Bolivia. I.17 - I.29.

Wunder, S. (2004): Policy options for stabilising the forest frontier: A global perspective. In: Gerold, G., M. Fremerey \& E. Guhardja (eds.) (2004): Land use, nature conservation and the stability of rainforest margins in Southeast Asia. Springer-Verlag Berlin Heidelberg New York.

Villarpando, R., S. Reichle \& M. Bertzky (2002): Clima. In: Ibisch, P. L., K. Columba \& S. Reichle (eds.) (2002): Plan de Conservación y Desarrollo Sostenible para el Bosque Seco Chiquitano, Cerrado y Pantanal Boliviano. Editorial FAN, Santa Cruz de la Sierra - Bolivia. II.1 - II.12.

Woltmann, S. (2000): Comunidades de aves del bosque en áreas alteradas y no alteradas de la concesión forestal la chonta, Santa Cruz, Bolivia. Documento Técnico 92/2000. Proyecto Bolfor - USAID.

\section{Home pages in Internet}

ACG (Area de Conservación Guanacaste) (2004): Online. Available at http://www.acguanacaste.ac.cr. Retrieved in May 2004.

Alianza Jatun Sacha (2004): Online. Available at http://www.jatunsacha.org/. Retrieved in June 2004.

Australian Bush Heritage (2004): Online. Available at http://www.bushheritage.asn.au. Retrieved in May 2004.

CODEFF (Comite Nacional Pro Defensa de la Fauna y Flora): Online. Available at http://www.codeff.cl/. Retrieved in June 2004.

BBC 2004. Online. Available at http://news.bbc.co.uk Retrieved on 3 October 2004. 
CEDARENA (2004). Online available at fttp:www.cedarena.org/landtrust. Retrieved in June 2004.

LTA (Land Trust Alliance) (2002): Annual Report. Online. Available at http://www.lta.org. Retrieved on 18 June 2004.

FCBC (Fundacion para la Conservación del Bosque Chiquitano) (2004): Online. Institutional information. Available at http://www.fcbcinfo.org. Retrieved on 18 October 2004.

FCBC (2004): Online. Relevant bio-ecological and socio-economics aspects. Available at http://www.fcbcinfo.org/eng/plan/5.htm. Retrieved on 29 July 2004.

FVSA (Fundación Vida Silvestre Argentina) (2004): Online. Available at http://www.vidasilvestre.org.ar. Retrieved in May 2004.

Megadiverse (2004): The biologically richest countries of the world. Online. Available at http://www.megadiverse.org/one.htm. Retrieved in May 2004.

Monteverde Costa Rica rainforest (2004): Online. Available at http://www.monteverdeinfo.com. Retrieved in May 2004.

Parque Pumalin (2004): Online. Available at http://www.pumalinpark.org/. Retrieved in June 2004.

PRONATURA, A. C. (2003): Programa Nacional de Tierras. Online. Available at www.pronatura.org.mx. Retrieved on 18 October 2004.

RESNATUR (Asociación Red Colombiana de Reservas Naturales de la Sociedad Civil) (2004): Information institutional. Online. Avaliable at www.resnatur.org.co. Retrieved on 18 October 2004.

TRFIC (The Tropical Rain Forest Information Center) (2004): Online. Available at http://bsrsi.msu.edu/trfic/LBA_E/. Retrieved on 10 February 2004.

USGS (2004): Shuttle Radar Topography Mission. Online. Available at http://srtm.usgs.gov/index.html. ftp://edcsgs9.cr.usgs.gov/pub/data/srtm. Retrieved in February 2004. 


\section{ANNEX}

Acronyms...........................................................................

List of the RPPN approved by the Forestry Superintendence in Bolivia until

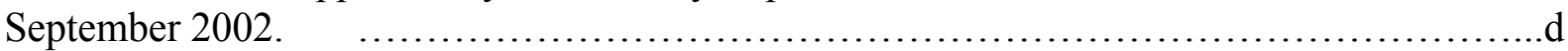

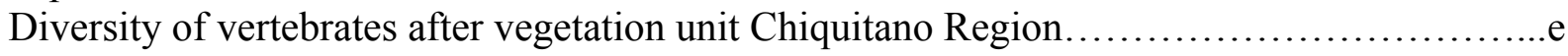

Conservation and Sustainable Development Spatial Vision...............................

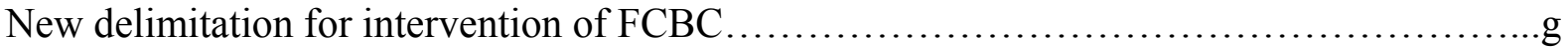




\section{ANNEX 1.}

\section{Acronyms}

APP Private Protected Areas (Chile)

ASL Asociación Social del Lugar

BP Bosque protector (Ecuador)

CEDARENA Centro de Derecho Ambiental y de los Recursos Naturales

CEMEX Cementos mexicanos

CI Conservation International

CODEFF Comite Nacional Pro Defensa de la Fauna y Flora (Chile)

CEDA Centro Ecuatoriano de Derecho Ambiental (Ecuador)

DEM Digital Elevation Model

ELI Environmental Law Institut

FAN Fundación amigos de la naturaleza (Friends of the nature Foundation)

FAN Fundacion Amigos de la Naturaleza (Bolivia)

FCBC Foundation for the Conservation of the Chiquitano Forest

FVSA Fundación Vida Silvestre (Argentina)

INRA Instituto Nacional de Reforma Agraria

INE Statistic National Institute (Bolivia)

LTA Land Trust Alliance

MDSP Ministerio de Desarrollo Sostenible y Planificación (Ministery of Sustainable

Development and Planning)

MHNNKM Museo de Historia Natural Noel Kempff Mercado. Universidad

Mayor Grabriel Rene Moreno

NAIM Natural Area of Integrated Management

NASA National Aeronautics and Space Administration

NHPRs Natural Heritage Private Reserves (Reserves Privadas del Patrimonio Natural Bolivia)

NWV Numeric weighted value

PNNK Noel Kempff National Park

PES Payment for environmental services

PRONATURA AC Asociación Civil Pronatura Mexico

PROMETA Protección Medio Ambiente Tarija (Bolivia)

POP Predial Ordering Plan 
PCSD Plan for the Conservation and Sustainable Development of the Chiquitano Dry, Pantanal and Bolivian Cerrado.

PLUS General Land Use Plan of Santa Cruz (Bolivia)

RESNATUR Asociación Red Colombiana de Reservas Naturales de la Sociedad Civil

RVS Reserva de Vida Silvestre (Argentina)

RVS Private National wildlife refuges (Costa Rica)

RPPN Private Reserves of Natural Patrimony (Brazil)

RRNSC (Colombia)

SPDA Sociedad Peruana de Derecho Ambiental

SIF Bolivian Forestry Superintendence

SIG Geographic Information System

SIA Agrarian Bolivian Superintendence

SEF Social and Economic Function of Land (Bolivia)

SERNAP National Service of Protected Areas (Bolivia)

TRFIC Tropical Rain Forest Information Center

TR-CHA Transitional Region Chiquitano - Amazon

TNC The Nature Conservancy

UN United Nations

UNESCO United Nations Educational, Scientific and Cultural Organization

USGS The United States Geological Survey

UTM Unidades Técnicas de Mercator 
ANNEX 2

\section{List of the RPPN approved by the Forestry Superintendence in Bolivia} until September 2002.

\begin{tabular}{|c|c|c|c|c|c|}
\hline No. & Name & Location & Ecoregions / Features to protect & $\begin{array}{l}\text { Total area } \\
\text { (ha) }\end{array}$ & $\begin{array}{c}\text { RPPN } \\
\text { area (ha) }\end{array}$ \\
\hline 1 & El Porvenir & $\begin{array}{l}\text { Nuflo de } \\
\text { Chávez } \\
\text { Santa Cruz }\end{array}$ & Chiquitano Dry Forest, fauna and landscape & $5,426.00$ & $4,577.00$ \\
\hline 2 & $\begin{array}{l}\text { San Miguelito, } \\
\text { Fundo }\end{array}$ & $\begin{array}{l}\text { Ñuflo de } \\
\text { Chávez Santa } \\
\text { Cruz }\end{array}$ & $\begin{array}{l}\text { Chiquitano Dry Forest, wildlife, aquatic } \\
\text { vegetation, San Julián river, recuperation of } \\
\text { faunal populations }\end{array}$ & $5,647.49$ & $1,064.15$ \\
\hline 3 & Los Remates & $\begin{array}{l}\text { Nuflo de } \\
\text { Chávez Santa } \\
\text { Cruz } \\
\end{array}$ & $\begin{array}{l}\text { Chiquitano Dry Forest, wildlife, aquatic } \\
\text { vegetation, San Julián river, recuperation of } \\
\text { faunal populations }\end{array}$ & $4,346.25$ & $2,507.61$ \\
\hline 4 & Monte Honda & $\begin{array}{l}\text { Ñuflo de } \\
\text { Chávez Santa } \\
\text { Cruz }\end{array}$ & $\begin{array}{l}\text { Chiquitano Dry Forest, wildlife, aquatic } \\
\text { vegetation, San Julián river, recuperation of } \\
\text { faunal populations }\end{array}$ & $4,211.20$ & $2,201.88$ \\
\hline 5 & Los Socios & $\begin{array}{l}\text { Ñuflo de } \\
\text { Chávez Santa } \\
\text { Cruz }\end{array}$ & $\begin{array}{l}\text { Chiquitano Dry Forest, wildlife, aquatic } \\
\text { vegetation }\end{array}$ & $3,642.00$ & $2,013.71$ \\
\hline 6 & Monte Grande & $\begin{array}{l}\text { Ñuflo de } \\
\text { Chávez Santa } \\
\text { Cruz } \\
\end{array}$ & $\begin{array}{l}\text { Chiquitano Dry Forest, wildlife, aquatic } \\
\text { vegetation, San Julián river, recuperation of } \\
\text { faunal populations }\end{array}$ & $3,584.60$ & 568.88 \\
\hline 7 & $\begin{array}{l}\text { Natividad } \\
\text { Corrales }\end{array}$ & $\begin{array}{l}\text { San Miguel- } \\
\text { Santa Cruz }\end{array}$ & $\begin{array}{l}\text { Chiquitano Dry Forest, aquatic vegetation, San } \\
\text { Julián river, recuperation of faunal populations }\end{array}$ & $7,099.97$ & $1,422.55$ \\
\hline 8 & $\begin{array}{l}\text { San Carlos, } \\
\text { San Pablo, } \\
\text { Natividad } \\
\end{array}$ & $\begin{array}{l}\text { Velasco Santa } \\
\text { Cruz }\end{array}$ & $\begin{array}{l}\text { Chiquitano Dry Forest, wildlife, aquatic } \\
\text { vegetation, San Julián river, recuperation of } \\
\text { faunal populations }\end{array}$ & $7,337.59$ & $2,557.33$ \\
\hline 9 & $\begin{array}{l}\text { Agropecuaria } \\
\text { El Oriente }\end{array}$ & \begin{tabular}{|l} 
Chiquitos \\
Santa Cruz
\end{tabular} & $\begin{array}{l}\text { Gran Chaco Dry Forest, Chiquitano Dry Forest, } \\
\text { wildlife, aquatic vegetation }\end{array}$ & $9,247.80$ & $5,000.00$ \\
\hline 10 & $\begin{array}{l}\text { Caraparicito - } \\
\text { Yaguapoa }\end{array}$ & $\begin{array}{l}\text { Cordillera } \\
\text { Santa Cruz }\end{array}$ & $\begin{array}{l}\text { Tucuman-Bolivian Forest, eastern sector of the } \\
\text { Serrania of Incahuasi, wildlife, natural springs }\end{array}$ & $8,750.00$ & $2,334.86$ \\
\hline 11 & El Corbalán & $\begin{array}{l}\text { Gran Chaco } \\
\text { Tarija }\end{array}$ & $\begin{array}{l}\text { Gran Chaco Dry Forest, high and low canyon } \\
\text { vegetation, fauna (birds and mammals) and } \\
\text { historical locations related to the war with } \\
\text { Paraguay }\end{array}$ & $2,500.00$ & $2,500.00$ \\
\hline 12 & El Güembé & \begin{tabular}{|l|} 
Nuflo de \\
Chávez \\
Santa Cruz \\
\end{tabular} & $\begin{array}{l}\text { Chiquitano Dry Forest, flora and fauna, } \\
\text { conservation of water resources, recuperation of } \\
\text { areas affected by fires }\end{array}$ & $2,798.00$ & 842.70 \\
\hline 13 & El Prado & $\begin{array}{l}\text { Velasco-Santa } \\
\text { Cruz }\end{array}$ & $\begin{array}{l}\text { Chiquitano Dry Forest and Cerrado, } \\
\text { watercourses, woody savannas, wildlife, } \\
\text { mountains and rocky outcrops }\end{array}$ & $5,063.38$ & $2,766.72$ \\
\hline 14 & San Sebastián & $\begin{array}{l}\text { Ñuflo de } \\
\text { Chávez } \\
\text { Santa Cruz } \\
\end{array}$ & Chiquitano Dry Forest & $3,454.00$ & $1,821.00$ \\
\hline 15 & El Triunfo & \begin{tabular}{|l|} 
Ñuflo de \\
Chávez \\
Santa Cruz \\
\end{tabular} & Chiquitano Dry Forest & 950.00 & 403.00 \\
\hline 16 & $\begin{array}{l}\text { Tacuarí and El } \\
\text { Porvenir }\end{array}$ & $\begin{array}{l}\text { Ñuflo de } \\
\text { Chávez } \\
\text { Santa Cruz } \\
\end{array}$ & Chiquitano Dry Forest & 954.00 & 111.00 \\
\hline 17 & \begin{tabular}{|l|} 
El Piyo, \\
Tacuari, Sion, \\
El Porvenir \\
\end{tabular} & $\begin{array}{l}\text { Ñuflo de } \\
\text { Chávez } \\
\text { Santa Cruz } \\
\end{array}$ & Chiquitano Dry Forest & $5,208.00$ & $1,021.00$ \\
\hline \multicolumn{4}{|c|}{ Total } & $80,220.88$ & $33,144.51$ \\
\hline
\end{tabular}

Source: SIF Bolivia 2002. 
ANNEX 3

\section{Diversity of vertebrates after vegetation unit chiquitano region}

Cuadro II.A.18 Diversidad de vertebrados (sin reptiles y peces) por unidad de vegetación.

\begin{tabular}{|l|l|l|l|l|}
\hline Unidad de vegetación & Anfibios & Aves & $\begin{array}{l}\text { Mamí- } \\
\text { feros }\end{array}$ & Total \\
\hline Chi.1. Bosque seco chiquitano de llanuras & 11 & 122 & 97 & 230 \\
\hline Chi.2. Bosque chiquitano anegado & 10 & 39 & 63 & 112 \\
\hline Chi.3. Bosque chiquitano ribereño & 34 & 63 & 55 & 152 \\
\hline Chi.4. Bosque seco de transición chiquitano-chaqueño & 6 & 66 & 41 & 113 \\
\hline Chi.5. Bosque seco chiquitano serrano ( o montano) & 13 & 33 & 62 & 108 \\
\hline Chi.7. Bosque húmedo de fondo de cañones & 8 & 5 & 44 & 57 \\
\hline Ce.1. Arboleda cerrada & 6 & 34 & 50 & 90 \\
\hline Ce.2. Arboleda abierta & 6 & 66 & 68 & 140 \\
\hline Ce.3. Sabana arbolada & 8 & 18 & 21 & 47 \\
\hline Ce.4. Sabana abierta & 6 & 20 & 21 & 47 \\
\hline Ce.5. Sabana abierta húmeda & 12 & 18 & 6 & 36 \\
\hline P.1. Sabana arbustiva inundada & 17 & 81 & 35 & 133 \\
\hline P.2. Sabana abierta inundada & 12 & 52 & 12 & 76 \\
\hline P.4. Palmares & Sin datos & 10 & 42 & 52 \\
\hline P.5., P.6., P.7. Curichales y Pantanos & 7 & 32 & 17 & 56 \\
\hline P.8. Colchal & 7 & 15 & 2 & 24 \\
\hline Cha.2. Cerrado chaqueño & Sin datos & 76 & 37 & 113 \\
\hline Pantanos* & 2 & 44 & 13 & 59 \\
\hline Plantas flotantes* & 6 & 9 & Sin datos & 15 \\
\hline Espejos de agua (ríos, lagunas, Bahías y quebradas)* & Sin datos & 55 & 2 & 57 \\
\hline Estas unidades de vegetacion se encuentran
\end{tabular}

Estas unidades de vegetación se encuentran incluidas en otras unidades en el mapa de vegetación

Source: Reichle, S., C. Eulert, N. Acheson, D. Rumiz, L. Gonzales, V. Fuentes, J. Sarmiento, T. Gutierrez \& P. L. Ibisch (2002): Fauna. Estado de conocimiento. In: Ibisch, P. L., K. Columba \& S. Reichle (eds.) (2002): Plan de Conservación y Desarrollo Sostenible para el Bosque Seco Chiquitano, Cerrado y Pantanal Boliviano. Editorial FAN, Santa Cruz de la Sierra - Bolivia. II.60 - II.71. 
ANNEX 4:

Conservation and Sustainable Development Spatial Vision

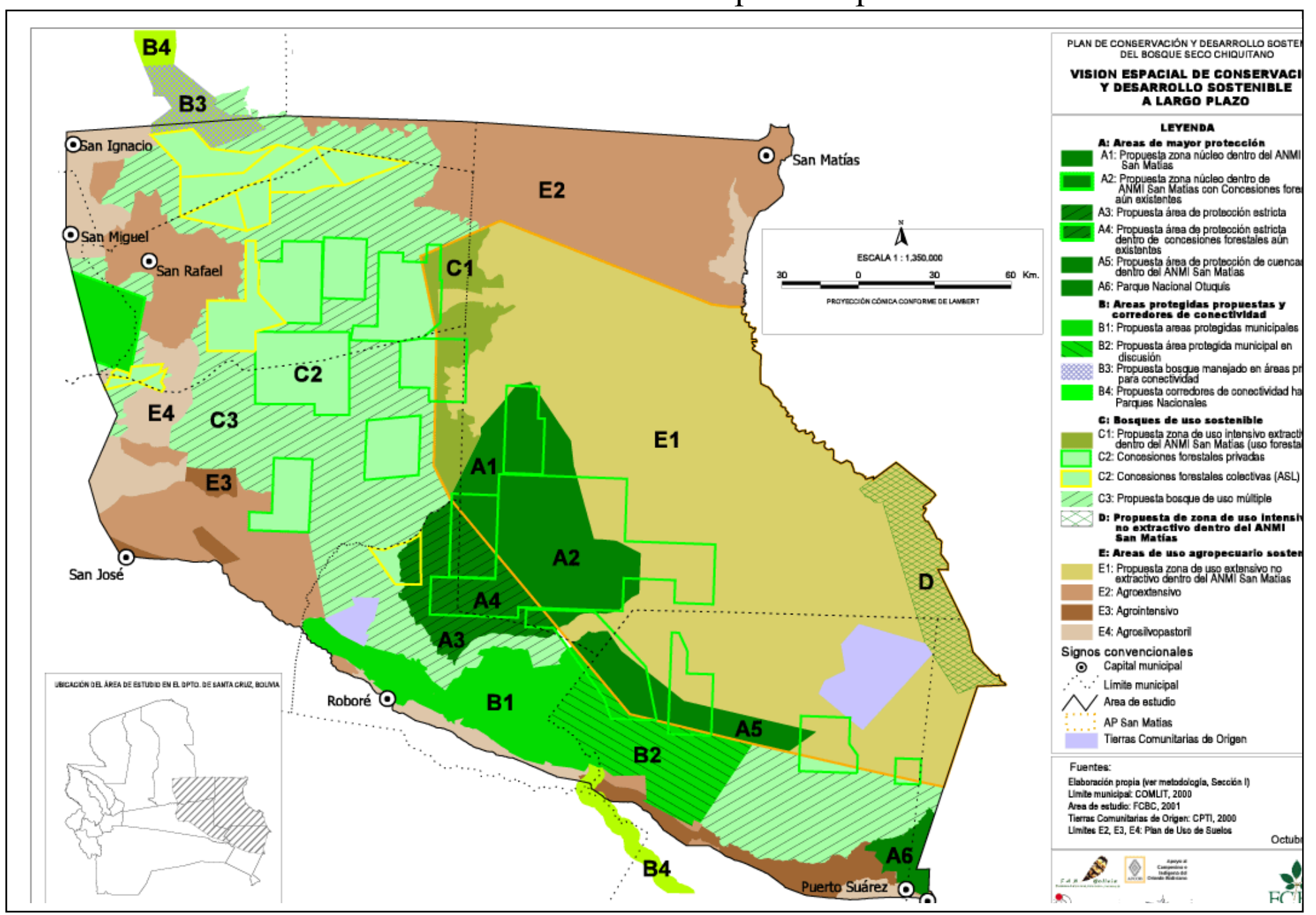


New delimitation for intervention of FCBC

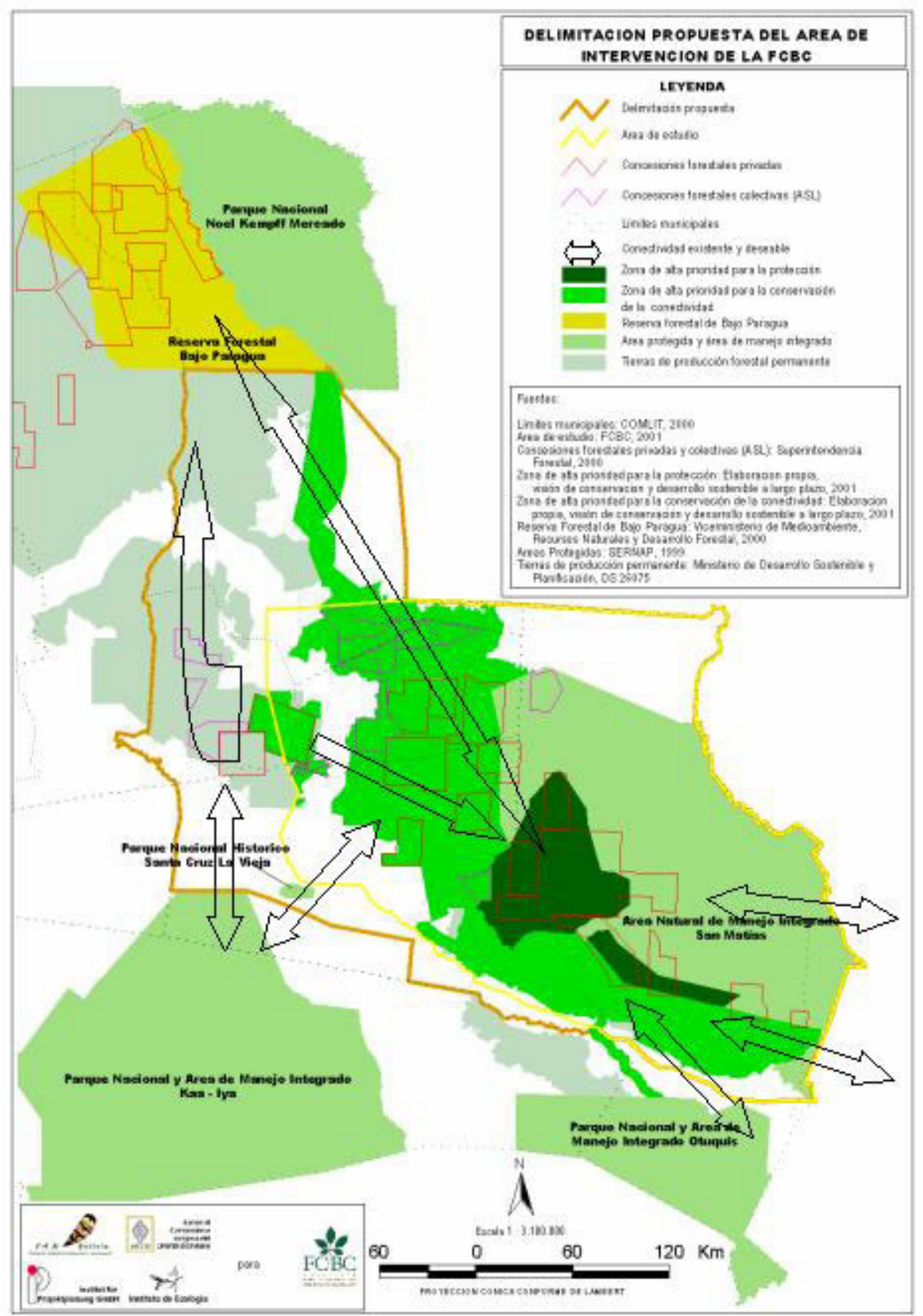




\section{LEBENSLAUF}

Name:

Geburtsdatum:

Geburtsort:

Staatsangehörigkeit:

\section{Schulausbildung}

07/1990

\section{Studium}

$09 / 2001$

$12 / 1997$

\section{Beruf}

Seit $03 / 2004$

$2001-2003$

$1998-1999$

$1997-1998$

$1993-1996$

Promotion

Seit 09/2001
Jorge Luis Choquehuanca Zeballos

06. Juni 1972

La Paz - Bolivien

Bolivianer
"Bolivar High Scholl", La Paz - Bolivien.

Abiturient

Georg-August-Universität Göttingen, Deutschland Magisters Scientiarum Agrariarum (M.sc.agr.)

in der Fachrichtung Tropen und Subtropen

Mayor de San Andres Universität, La Paz - Bolivien „Licenciado in Agraringenieurswesen“

Wissenschaftliche Hilfskraft, Abteilung Landschaftsökologie. Geographischen Institut der Georg-August-Universität

Göttingen, Deutschland

Fundación Amigos de la naturaleza (Stiftung der Freunde der Natur FAN-Bolivia), Santa Cruz- Bolivien

Chef der Abteilung für privaten Naturschutz

Fundación Amigos de la naturaleza (Stiftung der Freunde der Natur FAN-Bolivia), Santa Cruz, Bolivien.

Berater, vornehmlich für bodenkundliche Fragestellungen

Proyecto de Investigaciones Agrarias (Projekt für landwirtschaftliche Studien). La Paz, Bolivien Koordinator des Projektes

Universität Mayor de San Andres, La Paz-Bolivien Wissenschaftlicher Mitarbeiter

Abteilung Landschaftsökologie am Geographischen Institut der Georg-August-Universität Göttingen mit dem Dissertationsthema. 